NASA Contractor Report 3177

\title{
Effect of Grazing Flow on the
} Acoustic Impedance of Helmholtz Resonators Consisting of Single and Clustered Orifices

Alan S. Hersh and Bruce Walker

CONTRACT NAS3-19745

AUGUST 1979 
NASA Contractor Report 3177

\section{Effect of Grazing Flow on the Acoustic Impedance of Helmholtz Resonators Consisting of Single and Clustered Orifices}

Alan S. Hersh and Bruce Walker Hersh Acoustical Engineering

Chatsworth, California

Prepared for

Lewis Research Center

under Contract NAS3-19745

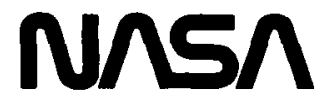

National Aeronautics

and Space Administration

Scientific and Technical

Information Branch 


\section{TABLE OF CONTENTS}

SUMMARY .............................. 1

DEFINITION OF SYMBOLS...................... 2

1. INTRODUCTION ............................ 5

2. SINGLE ORIFICE IMPEDANCE MODEL .................. 7

2.1 Derivation of Governing Equations.............. 8

2.2 Boundary Conditions................... 12

2.3 Semi-empirical Solution.................. 13

3. SINGLE ORIFICE MEASUREMENT PROGRAM.................. 17

3.1 Two-Microphone Method................... 18

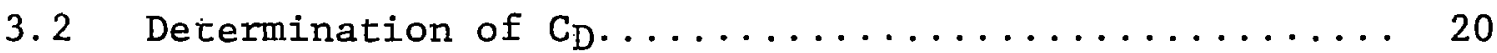

3.3 Comparison Between Predicted and Measured Impedance.. 25

3.4 Thick Orifices.......................... 29

3.5 Resonator Self-Noise................... 31

4. IMPEDANCE OF CLUSTERED ORIFICES. . . . . . . . . . . . . . 32

4.1 Zero Grazing Flow, Low Sound Amplitude Results...... 33

4.2 Effect of Grazing Flow................... 35

5. CONCLUSIONS ........................... 38

APPENDIXES

A - SINGLE ORIFICE DATA................... 40

B - SUMMARY OF FREQUENCY SWEEP DATA FOR SPECIAL MODEL FOR $V_{\infty}^{*}=60 \mathrm{~m} / \mathrm{sec}$ and $P_{i}^{*}=120 \mathrm{~dB} \ldots \ldots \ldots 66$

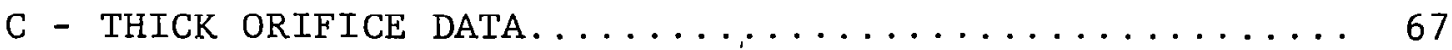

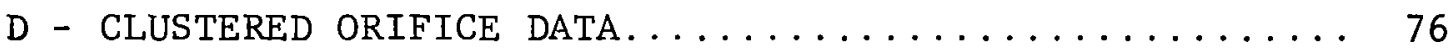

REFERENCES ................................ 104

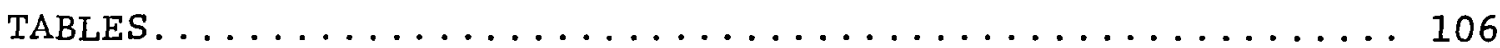

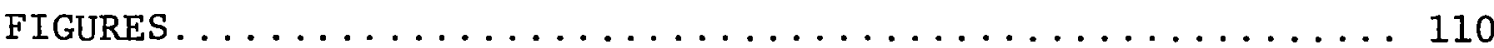




\section{SUMMARY}

A semi-empirical fluid mechanical model is derived for the acoustic behavior of thin-walled single orifice Helmholtz resonators in a grazing flow environment. The model assumes that the flow field incident to a resonator orifice consists of a spherical sound particle velocity field superimposed upon a mean grazing flow. The incident and cavity sound fields are connected in terms of an orifice discharge coefficient whose values are determined experimentally using the two-microphone method. With regard to its application to aircraft engines, the most important finding of this study is that at high grazing flow speeds, acoustic resistance is almost linearly proportional to the grazing flow speed and almost independent of incident sound pressure. The corresponding values of reactance are much smaller and tend towards zero for increasing grazing flow speed. Because of their insensitivity to the incident sound, the impedance of Helmholtz resonators at high grazing flow speeds is almost "linear".

The effects of grazing flow on the acoustic behavior of thick-walled single orifice Helmholtz resonators were studied experimentally. Test results showed both resistance and reactance to become increasingly less sensitive to the grazing flow as the ratio of plate thickness to orifice diameter increased.

Loud resonant tones were observed to radiate from single orifice Helmholtz resonators due to interaction between the grazing flow shear layer and the resonator cavity. The tones occurred at a grazing flow speed defined as $\left(V_{\infty}^{*}\right)$ res $=f *$ res $d^{*} / 0.26$ where f*es is the resonator classical Helmholtz resonant irequency and $d^{*}$ is the orifice diameter. Measurements show that for grazing flow speeds greater than ( $V_{\infty}^{*}$ ) res, the grazing flow dominates the resonator behavior and for grazing flow speeds less than $\left(V_{\infty}^{*}\right)$ res, the sound particle velocity field dominates the resonator behavior.

The two-microphone method was also used to measure the effect of grazing flow on the impedance of Helmholtz resonators consisting of clusters of orifices. The study showed that interaction between nearby orifices occur only for those orifices whose centers are aligned parallel to the grazing flow. Interaction does not occur for orifices whose centers are aligned perpendicular to the grazing flow. In general, both resistance and reactance are virtually independent of orifice relative spacing and number. Orifice end correction, on the other hand, is quite dependent upon orifice spacing. It is fairly insensitive to the number of orifices. These findings are valid with and without grazing flow. 
DEFINITION OF SYMBOLS

Symbo1

A ; $A_{f}$

$A_{\text {min }}$

$c$

${ }^{c} \mathrm{D}$

d

$d_{e}$

D

E

$\widetilde{E}$

$b_{1}$

$f(t) ; f$

$F(t)$

$G(t)$

$\mathrm{L}$

$\mathrm{L}_{\mathrm{e}}$

$\mathrm{M}_{\infty}$

$\mathrm{N}$

$\mathrm{p}$

$\mathrm{P}_{\mathbf{i}}$

$\mathrm{P}_{\mathrm{C}}$

$q^{\prime}$

$\mathrm{r}$

$\mathrm{R}_{\mathrm{O}}$

$s ; s_{f}$

$\mathrm{S}_{\mathrm{O}}$

$S_{\text {vc }}$

$S_{\infty}$

$\mathrm{t}$
Definition

orifice area; also Fok area defined by Fig. 1.

minimum area enclosed by orifices

speed of sound (meters/sec)

discharge coefficient defined by Eq. (8)

diameter of coefficient (meters)

orifice inertial length (meters)

diameter of cylindrical cavity (meters)

small parameter defined by Eq. (8)

sma11 parameter defined by Eq. (26)

special parameter defined by Eq. (28b)

special function defined by Eq. (14); also frequency

function of time defined by Eq. (29)

special function defined by Eq. (24)

cavity depth (meters)

resonator characteristic length (meters)

grazing flow Mach number $\left(\mathrm{V}_{\infty} / \mathrm{c}\right)$

number of orifices backed by a common

cavity

acoustic pressure (Newtons/meters ${ }^{2}$ )

amplitude of incident sound wave (Newtons/ meters ${ }^{2}$ )

amplitude of cavity sound wave (Newtons/ meters ${ }^{2}$ )

sound particle velocity

(meters/sec)

radial coordinate (meters)

orifice area-averaged acoustic resistance $\left(\mathrm{Kg} / \mathrm{meters}^{2} / \mathrm{sec}\right)$

separation distance between adjacent array (m);

Fok separation parameter defined in Fig. 1.

orifice area (meters ${ }^{2}$ )

orifice vena contracta area (meters ${ }^{2}$ )

defined in Fig. 8 (meters)

time (sec) 
$u_{v c}$

$u, v, w$

$\mathrm{V}_{\mathrm{c}}$

$v_{\infty}$

$\mathrm{d}_{\mathrm{e}}$

$x_{o}$

$z_{0}$

$\alpha$

$\varepsilon$

$\rho$

$\delta$

$\delta_{0}$

$\xi$

$\omega$

$\eta$

$\sigma$

$\tau$

$\psi^{\prime}(\xi)$

$\theta$

$\phi$

$\phi_{i c}=-\phi_{c i}$

\section{Subscripts}

i

c

N

BL

O

$0, \mathrm{~N}$

res

v.c. acoustic particle velocity at orifice vena contracta (meters/sec)

radial, polar, azimuthal acoustic particle velocity components (meters/sec)

resonator cavity volume (meters ${ }^{3}$ )

grazing flow speed (meters/sec)

resonator orifice inertial length (meters)

resonator orifice area-averaged reactance $\left(\mathrm{Kg} / \mathrm{meters}{ }^{2} / \mathrm{sec}\right)$

resonator orifice area-averaged impedance $\left(\mathrm{Kg} / \mathrm{meters}^{2} / \mathrm{sec}\right)$

parameter defined by Eq. (20)

small parameter defined by Eq. (8)

fluid density ( $\mathrm{Kg} /$ meters $^{3}$ )

grazing flow boundary-layer thickness (metcrs)

orifice end correction (meters)

orifice array interaction parameter (d/D)

incident sound field radian frequency $(\mathrm{Hz})$

nondimensional parameter defined by Eq. (46)

resonator orifice percent open area

orifice plate thickness (meters)

Fok interaction function

spherical coordinate polar angle

spherical coordinate azimuthal angle

phase angle shift across orifice (deg.)

incident

cavity

refers to $N$ orifices

boundary 1 ayer

orifice

orifice referenced to $\mathrm{N}$

refers to resonator resonant frequency

refers to orifice vena contracta 
Subscripts

$\mathrm{t}$

Superscripts

( )'

()$^{*}$
Definition

refers to total resonator

refers to fluctuating quantities

refers to dimensional quantities 
1.

\section{INTRODUCTION}

The application of arrays of cavity-backed orifices as sound absorbing devices in the inlet and exhaust of jet engines has generated the need to understand their acoustic behavior in a high speed grazing flow environment. This need has prompted a number of research investigations aimed at predicting the effect of grazing flow on the impedance of isolated orifices. Early experimental studies by Mechel, Mertens and Schilz, Phillips ${ }^{2}$, Ronneberger ${ }^{3}$ and Dean ${ }^{4}$ showed that relative to their zero grazing flow values, the effects of grazing flow are to increase orifice resistance and decrease orifice reactance. Dean noted that some of the resonators exhibited an increase in reactance with grazing flow while others exhibited a decrease. He offered no explanation for this.

Recent studies by Rogers and Hersh ${ }^{5}$, Baumeister and Rice ${ }^{6}$, Hersh and Rogers ${ }^{7}$ and Rice ${ }^{8}$ have added greatly to our understanding of the acoustic behavior of Helmholtz resonators in a grazing flow environment. Rogers and Hersh correlated measurements of the steadystate resistance of isolated square-edged orifices in a grazing flow environment in terms of an effective orifice discharge coefficient. By introducing a simple inviscid model based on this airfoil theory to account for the interaction between the grazing flow and the orifice inflow and outflow, Rogers and Hersh showed that the discharge coefficient decreased to very small values relative to its classical zero grazing flow speed value of near 0.6 . Rogers and Hersh showed by means of simple flow visualization techniques that the reduction in $C_{D}$ results from a blockage of the orifice area by interaction between the grazing flow and the orifice inflow and outflow in the form of complicated eddies.

Baumeister and Rice conducted a very detailed visual study of interaction between a steady-state grazing flow and an oscizlating orifice flow. Flow visualization was achieved by constructing a flow channel and a single orifice side branch Helmholtz resonator out of plexiglass and using water as the fluid medium. An oscillatory flow was applied to the resonator cavity and color dyes were injected in both the orifice and the grazing flow. High speed cameras were used to record the motion of the fluid. An important finding of their study is that interaction between the steadystate grazing flow and the oscillating orifice inflow and outflows reduced the orifice effective open area.

Hersh and Rogers derived a fluid mechanical model of the acoustic behavior of isolated circular orifices for the case of 
non-grazing flow. By assuming that the sound particle velocity field approaches the orifice as a spherically symmetric radial flow, they showed to lowest order that the particle velocity field near the orifice is incompressible and unsteady. They further showed that at high incident sound pressure levels, the particle velocity is nonlinear. In this regime, the resistance, proportional to the square root of the amplitude of the incident sound pressure field, is much larger than the orifice inertial reactance or the cavity stiffness reactance.

Rice extended the work of Hersh and Rogers to include the effects of a high speed grazing flow. He derived a physically meaningful solution by assuming that the velocity field consists of a spherically symmetric particle velocity component superimposed upon a uniform grazing flow. Rice showed that when the grazing flow speed is sufficiently large (relative to the amplitude of the sound particle velocity field), the orifice resistance is 1 inearly proportional to the grazing flow speed and independent of the amplitude of the incident sound.

The above review dealt only with isolated orifices. Previous work related to the effects of multiple or clustered orifices is discussed below. In the application of cavity-backed orifices as sound absorbing devices, possible interaction among neighboring orifices has been traditionally ignored in the design process, probably because of the lack of available data to assess its importance. This is especially true for the intense sound pressure levels and high grazing flows within jet engines.

A review of the 1 iterature indicates that the previous studies of interacting orifices, conducted by Ingard 9 and Fok ${ }^{10}$ considered only the special cases of zero grazing flow $\left(V_{\infty}^{*}=0\right)$ and low sound pressure levels (i.e., the linear regime). ${ }^{\infty}$ Mellin ${ }^{11}$ recently reviewed their models. Briefly, both Ingard and Fok derived theoretical expressions for the interaction. Ingard's solutions indicate that the orifice end correction is strongly dependent upon the spacing between orifices. Me11in applied Fok's model to derive the following expression for the Helmholtztype specific reactance $\chi_{0}^{\star}$ (igncring the small viscous contribution),

$$
x_{0}^{*} \simeq \frac{\rho^{*} \omega^{*}}{\sigma}\left[\tau^{*}+\frac{0.85 d^{*}}{\psi^{\prime}(\xi)}\right] \equiv \frac{\rho^{*} \omega^{*} d_{e}^{*}}{\sigma}
$$

where $\rho^{*}$ is the fluid density, $\omega^{*}$ the radian sound frequency, $\sigma$ is the plate porosity, $\tau^{*}$ is the plate thickness, $d^{*}$ the (circular) orifice diameter, $\mathrm{d}_{\mathrm{e}}{ }^{*}$ is the orifice effective inertial length, and $\psi^{\prime}(\xi)$ is the Fok interaction function defined in Fig. 1. Here $\xi^{=d^{*} / S^{*}} f$ is an interaction parameter where $d^{*}$ is 
the orifice diameter and $S_{f}^{*}=\sqrt{\frac{4 A_{f}^{*}}{\pi}}$, $A_{f}^{*}$ being the zone area of each orifice as shown in Fig. 1. It is clear from Fig. 1 and Eq. (1) that when $\xi<0.2$, the effect of the interaction function $\psi^{\prime}(\xi)$ is sma11. When $\xi^{\prime}=1$, the end correction disappears. Physically, this corresponds to the orifice area equal to the entire plate area - hence the impedance reduces to the characteristic impedance $\rho^{*} c^{*}$ of the fluid. In this sense changes of the varjable $\xi$ in Fok's model corresponds to changes of the percent open area of the perforated plate.

The purpose of this report is two-fold. The first is to present the results of a semi-empirical prediction model of the effects of grazing flow on the acoustic impedance of Helmholtz resonators consisting of cavity-backed isolated orifices. The second is to present the results of an experimental investigation of the effects of multiple orifices on the impedance of Helmholtz resonators in a grazing flow environment.

The study is organized as follows. In Section 2 , the semi-empirical model is derived. The model is refined in Section 3 by comparing it with experimental data measured using the two-microphone method. The results of the investigation of the effects of clustered orifices are presented in section 4 . The main findings of this study are summarized in Section 5 .

2. SINGLE ORIFICE IMPEDANCE MODEL

The approach used in the derivation of the mode1 is based in part upon the flow visualization study by Baumeister and Rice. Figure 2, taken from their study, illustrates the complexity of the interaction between the grazing flow and the incident sound field. During the inflow half-cycles, the grazing flow is deflected laterally into the cavity forming the vena contracta shown. During outflow, an equal amount of sound particle volume flow is pumped out of the cavity. In both cases, the effective area through which the sound particle volume flow enters and exits the cavity appears to be less than the orifice area $\left(\pi d^{* 2} / 4\right)$. The photograph suggests that the sound particle velocity field separates at the orifice upstream lip - it enters and exits the cavity near the orifice downstream 1 ip.

It is clear that a detailed solution of the interaction is not practical. Instead, a semi-empirical solution is sought which assumes that during the inflow half-cycle, the sound particle enters the resonator cavity in the spherical, radically symmetric manner suggested in Figs. $(3 a, b)$. The radius $r^{*}=L_{e}^{*}$ shown is defined such that the instantaneous particle volume flow passing through the hemispherical surface area $2 \pi \mathrm{L}_{\mathrm{e}}^{*}{ }^{2}$ is equal to the actual instantaneous particle volume flow rate 
entering the cavity through the vena contracta. The quantity $\mathrm{L}_{\mathrm{e}}^{*}$ must be determined experimentally. The construction of Fig. ( $3 b$ ) is based upon the flow visualization study of Baumeister and Rice.

The spherical inflow model is obviously valid only during the half-cycle when the incident sound particle velocity is approaching the orifice - it is not valid during the other halfcycle when the sound is exiting from the orifice. It is known from the flow visualization studies by Baumeister and Rice that the sound particle flow exits from the orifice in a jet-1ike manner. The restriction of the model to inflow only is not unduly limiting, however, because the quantity of particle flow pumped into and out of the resonator volume should be equal over a sound period. Thus an approximate solution over a half-cycle should result in an approximate solution over the entire cycle.

The background information described above provides the basis for the following approach. The fluctuating continuity and momentum conservation equations describing the motion of a simply harmonically driven sound particle velocity field in the presence of a steady-state grazing flow are derived. Following this, the equations of motion are normalized by appropriately scaling the dependent and independent variables. The resulting equations are then simplified by retaining only the important terms. The simplified equations of motion are solved so as to satisfy two boundary conditions. One is that the fluctuating pressure must merge smoothly (asymptotically) into the incident driving pressure. The other is that at the hemispherical surface $\mathrm{r}^{*}=\mathrm{L}_{\mathrm{e}}^{*}$ (see Fig. 3b) the inflow instantaneous pressure must be equal to the instantaneous cavity pressure.

\subsection{Derivation of Governing Equations}

The derivation of the governing equations is based upon the following assumptions: (1) The flow field is decomposed into uniform and fluctuating components. (2) The fluctuating sound particle velocity field approaches the resonator orifice in a spherically symmetric manner. (3) The incident sound is simple harmonic. The sound wave-length is very much larger than the cavity and orifice dimensions. (4) The acoustic pressure and density are adiabatically related. (5) The fluid is inviscid.

As sumptions (1) and (2) are central to the derivation of the semi-empirical model. A spherical coordinate system is used in the analysis. Refcrring to Fig. (3), $V_{\infty}^{*}$ represents the steady grazing flow aligned in the $x^{*}$-direction. The fluctuating velocity field is written in spherical coordinates with components $\left(\mathrm{u}^{*}, \mathrm{v}^{*}, \mathrm{w}^{*}\right)$ aligned in the $\left(\mathrm{r}^{*}, \theta, \phi\right)$ directions. The sound field is generated by a source located far away from the resonator orifice (far in terms of the orifice diameter). 
From assumption (2) above, the radial component $u^{*}$ ' of the sound particle velocity field is independent of the polar and azimuthal angles $\theta$ and $\phi$. Following the approach used by Rice, the steady grazing flow is assumed to be orientated as shown in Fig. (3). Written in spherical coordinates, the grazing flow and sound particle velocity fields are, respectively,

$$
\begin{gathered}
\underline{V_{\infty}^{*}}=\left(-V_{\infty}^{*} \sin \theta \cos \phi,-V_{\infty}^{*} \cos \theta \cos \phi, V_{\infty}^{*} \sin \phi\right) \\
\underline{q^{* \prime}}=\left(u^{* \prime}, 0,0\right)
\end{gathered}
$$

where the asteriks denote dimensional quantities, ( )' denotes acoustic quantities and ( ) denotes a vector quantity.

The flow field is decomposed into steady and fluctuating components. To simplify the analysis, the governing fluctuating continuity and momentum conservation equations (the energy equation is replaced by assumption \#4) are nondimensionalized by introducing the reference quantities $\left(\omega^{*}\right)^{-1}, L^{*} e, u_{v c}^{*}, V_{\infty}^{*}, P_{i}^{*}$ '. Here $\omega^{*}$ is the sound radian frequency, $L^{*} e$ is a characteristic length to be defined experimentally later, $u_{v c}^{*}$ is the amplitude of the sound particle speed entering the resonator cavity at the orifice vena contracta (i.e., the maximum amplitude), $V_{\infty}^{*}$ is the steady grazing flow speed, and $\mathrm{P}^{\star}$ is the amplitude $\mathrm{Qf}^{\infty}$, the ${ }^{\text {inci- }}$ is
dent sound field. It is assumed that the quantities $\mathrm{P}_{i}^{*}, V_{\infty}^{*}$ and $u_{v c}^{* \prime}$ are related as follows

$$
P_{i}^{*^{\prime}}=C_{D} \rho^{*} v_{\infty}^{*} u_{v c}^{*^{\prime}}
$$

where $C_{D}$ is the orifice discharge coefficient which will be defined later (see Eq. 13).

The above dimensional quantities are used to normalize the fluctuating continuity and momentum conservation equations. Introducing the following non-dimensional quantities

$$
t^{*}=\left(\omega^{*}\right)^{-1} t ; r^{*}=L_{e}^{*} r ; u^{*^{\prime}}=u_{v c}^{*^{\prime}} u ; P^{* \prime}=P_{i}^{*^{\prime}} p ; \rho^{*^{\prime}}=\frac{P_{i}^{* \prime}}{c^{* 2}} \rho=\frac{P_{i}^{* \prime}}{c^{* 2}} P
$$


into the fluctuating continuity and radial momentum equations yields

Continuity Eqn.

$C_{D}^{2} M_{\infty}^{2} E \frac{\partial p}{\partial t}+\left[1+C_{D} M_{\infty} \frac{u_{v c}^{*}}{c^{*}} p\right] \frac{1}{r^{2}} \frac{\partial}{\partial r}\left(r^{2} u\right)+C_{D} M_{\infty} \frac{u_{v c}^{*^{\prime}}}{c^{*}} u \frac{\partial p}{\partial r}$

$-C_{D} M_{\infty}^{2} \sin \theta \cos \phi \frac{\partial p}{\partial r}-\frac{C_{D} M_{\infty}^{2}}{r} \cos \theta \cos \phi \frac{\partial p}{\partial \theta}+\frac{C_{D} M_{\infty}}{r} \frac{\sin \phi}{\sin \theta} \frac{\partial p}{\partial \theta}=0$

Radial Momentum Eqn.

$$
E \frac{\partial u}{\partial t}-\frac{1}{C_{D}} \sin \Theta \cos \phi u+\varepsilon u \frac{\partial u}{\partial r}+\frac{\partial p}{\partial r}=0
$$

where

$$
E \equiv \frac{\omega^{*} L_{e}^{*}}{C_{D} V_{\infty}^{*}} ; \varepsilon \equiv \frac{P_{i}^{* \prime}}{\rho^{*} C_{D}^{2} V_{\infty}^{* 2}}
$$

The momentum flux conservation equations in the $\theta$ and $\phi$ directions are not included because they do not contribute direct1y to the impedance model prediction.

The continuity equation (Eq. 6) can be simplified to

$$
\frac{\partial}{\partial r}\left(r^{2} u\right)=0 \longrightarrow u(r, t)=-F(t) / r^{2}
$$

providing that

$$
C_{D}^{2} M_{\infty}^{2} E \ll 1 ; \quad C_{D} M_{\infty} \ll 1
$$


The constraints described by Eq. (10) will be shown later to be satisfied for any subsonic mean flow. Substituting Eq. (9) into Eq. (7) and integrating with respect to $r$ yields the equation

$$
\frac{E \dot{F}(t)}{r}-\frac{\sin \theta \cos \phi}{C_{D} r} F(t)+\frac{\varepsilon}{2 r^{4}}[F(t)]^{2}+p(r, \theta, \phi, t)=f(t)
$$

where $f(t)$ is an arbitrary function of time to be determined from the boundary conditions described below.

The simplified continuity equation [Eq. (9)] shows that to lowest order, fluid is pumped into and out of the cavity in an unsteady incompressible manner. This is consistent with the interpretation that significant flow field changes occur over distances small relative to the incident sound wavelength (see assumption 3 ). Under these conditions, flow field changes must occur hydrodynamically rather than acoustically. Referring to Fig. ( $3 \mathrm{~b})$, the incompressibility of the flow pumped into and out of the orifice permits the following interpretation of $\mathrm{L}_{e}{ }^{*}$. $\mathrm{Re}$ call that the characteristic length $L_{e}$ * was defined such that the volume flow rate of fluid pumped through the hemispherical surface area $2 \pi L_{e} *^{2}$ is equal to the actual volume flow rate through the orifice vena contracta (see Fig. 3b). For incompressible flows, conservation of mass leads to the following connection between $\mathrm{L}_{e}{ }^{*}$ and the orifice diameter $\mathrm{d}^{*}$,

$$
\underbrace{S_{v c}^{*}\left(-u^{*}\right)_{v c}}_{\begin{array}{c}
\text { volume flow rate } \\
\text { through vena contracta }
\end{array}}=\underbrace{S_{0}^{*}\left(-u^{*}\right)_{0}}_{\begin{array}{c}
\text { volume flow rate } \\
\text { through orifice }
\end{array}}
$$

Here $\left(-u^{*}\right)$ denotes inflow towards the orifice as the spherical coordinate system defined by Fig. ( $3 a$ ) assumes outflow is positive, $S^{*}{ } C_{C} \equiv 2 \pi \mathrm{L}_{\mathrm{e}}{ }^{2}$ is the vena contracta cross-sectional area, $\mathrm{S}_{\mathrm{O}}^{*} \equiv \mathrm{d}^{*} / 4$ is the orifice cross-sectional area, $\left(-\mathrm{u}^{* 1}\right)$ vc is the sound particle speed in the vena contracta and $\left(-u^{* 1}\right)_{0}$ is the orifice area-averaged sound particle speed. The discharge coefficient $C_{D}$ is defined herein as the ratio of the sound particle orifice-area averaged speed to vena contracta speed. Combining this definition with Eq. (12) leads to

$$
C_{D} \equiv \frac{\left(-u^{*^{\prime}}\right)_{0}}{\left(-u^{*^{\prime}}\right)_{v c}}=\frac{S_{v c}^{*}}{S_{0}^{*}}=8\left(\frac{L_{e}^{*}}{d^{*}}\right)^{2}
$$


Thus the characteristic length $\mathrm{L}_{\mathrm{e}}$ * is related to the orifice discharge coefficient.

\subsection{Boundary Conditions}

The solution to $\mathrm{Eq}$. (11) requires that the functions $f(t)$ and $\mathrm{p}(\mathrm{r}, \theta, \phi, t)$ be known. There are two known boundary conditions that suffice to identify $f(t)$ and $p(r, \theta, \phi, t)$. First, the local pressure $p(r, t, \theta, \phi)$ must merge smoothly (asymptoticaliy) into the (normalized) incident sound driving pressure. From Eq. (11), this yields

$$
\operatorname{Lim}_{r \rightarrow \infty} p(r, \theta, \phi, t)=f(t)=\cos (t)
$$

The second boundary condition is imposed by the connection between the incident sound particle velocity and the response of the cavity sound pressure. Refcrring to Fig. ( $3 \mathrm{~b}$ ), the sound particle field separates at the lip of the orifice. This separation implies that the local acoustic pressure $p(r, \theta, \phi, t)$ must be instantaneously equal to the time-dependent cavity back-pressure. From the sketch shown in Fig.(3b), it is clear that the flow is not spherical within the orifice. To avoid obvious horrendous mathematical problems, the actual instantaneous volume flow entering the cavity wili be assumed to do so in a spherical manner. The matching of the spherical to the actual volume flow rate is determined experimentally by measuring indirectly the reference length $\mathrm{L}_{e}{ }^{*}$. As far as the cavity pressure is concerned, it responds only to the instantaneous volume flow entering (or exiting) through the orifice (or more precisely through the orifice vena contracta). In this sense it responds on $1 y$ to the instantaneous volume flow rate. This means that within the context of the spherical inflow model, the acoustic pressure is independent of the spherical angles $\theta$ and $\phi$. Thus the second boundary condition, written in dimensional terms, is

$$
\frac{\partial P_{c}^{*}}{\partial t^{*}}\left(r^{*}=L_{e}^{*}, t^{*}\right)=c^{*^{2}} \frac{\partial \rho_{c}^{*}}{\partial t^{*}}\left(L_{e}^{*}, t^{*}\right)=\frac{c^{*} \rho^{*} S_{v c}^{*}\left(-u^{*}\right)_{v c}}{V_{c}^{*}}
$$

Equation (15) uses assumption (\#4) of Section 2.1 above to connect adiabatically the time rate of increase of cavity pressure to the particle volume inflow (and by symmetry outflow) into the cavity. Nondimensionalizing Eq. (15) and replacing $\mathrm{S}_{\mathrm{Vc}}{ }^{*}$ by $\mathrm{C}_{\mathrm{D}} \mathrm{S}_{\mathrm{O}}$ * using Eq. (13), the second boundary condition, written in nondimensional terms, is 


$$
\frac{\partial P_{c}}{\partial t}(r=1, t)=\frac{c^{*^{2}} \rho^{*} C_{D} S_{0}^{*} u_{v c}^{*} F(t)}{V_{c}^{*} \omega^{*} \underbrace{C_{D} \rho^{*} V_{\infty}^{*} u_{v c}^{* 1}}_{P_{i}^{*}}}=\frac{c^{*^{2}} S_{0}^{*} F(t)}{V_{c}^{*} \omega^{*} V_{\infty}^{*}}
$$

Equation (16) can be written in a more convenient form by introducing the classical expression for the resonant frequency of a Helmholtz resonator at zero grazing flow exposed to very low incident sound (see Reference 9)

$$
\omega_{r e s}^{*^{2}}=\frac{c^{*^{2}} S_{0}^{*}}{V_{c}^{*} d_{e}^{*}}
$$

where $d_{e} *$ is the orifice inertial length defined as the orifice thickness plus end correction

$$
d_{e}^{*} \equiv \tau^{*}+\delta_{0}^{*} \simeq \tau^{*}+0.85 d^{*} /\left(1-1.25 \frac{d^{*}}{D^{*}}\right)
$$

Using Eqs. (8) and (17) with Eq. (16) yields

$$
\frac{\partial p}{\partial t}(1, t)=\left(\frac{\omega_{\text {res }}^{*}}{\omega^{*}}\right)^{2}\left(\frac{\omega^{*} L_{e}^{*}}{C_{D} V_{\infty}^{*}}\right) C_{D}\left(\frac{d_{e}^{*}}{L_{e}^{*}}\right) F(t) \equiv E \alpha F(t)
$$

where

$$
\alpha \equiv\left(\frac{\omega_{\text {res }}^{*}}{\omega^{*}}\right)^{2} C_{D}\left(\frac{d_{e}^{*}}{L_{e}^{*}}\right)=\left(\frac{\omega_{\text {res }}^{*}}{\omega^{*}}\right)^{2} \sqrt{8 C_{D}}\left(\frac{d_{e}^{*}}{d^{*}}\right)
$$

The RHS of Eq. (20) follows from the relationship between $\mathrm{L}_{\mathrm{e}}$ * and $\mathrm{d}^{*}$ defined by Eq. (13).

\subsection{Semi-empirical Solution}

The final equation describing the effect of grazing flow on the sound field follows by combining Eq. (11) with the boundary conditions described by Eqs. (14) and (19). In the process of deriving the final equation, it is important to understand that the instantaneous time rate of change of the cavity pressure described by Eq. (19) is a function of only the instantaneous sound particle volume rate entering (or exiting) the cavity thus it is independent of the angles $\theta$ and $\phi$. To relate Eq. (11), 
which describes the instantaneous behavior of the acoustic pressure at $\mathrm{r}=1$ to $\mathrm{Eq}$. (19), it must be first averaged over the hemispherical surface of radius $r=Z\left(r^{*}=L e^{*}\right)$ and then differentiated with respect to time. Defining,

$$
\langle()\rangle \equiv \frac{1}{2 \pi} \int_{0}^{2 \pi} d \phi \int_{0}^{\frac{\pi}{2}}() \sin \theta d \theta
$$

and applying it to Eq. (11) yields (at $r=1$ ),

$$
E \dot{F}(t)+\frac{\varepsilon}{2}[F(t)]^{2}+\langle P(1, t)\rangle=f(t)
$$

What is important here is that upon averaging $E q$. (2I), the convective term - sintcos $\phi F(t) / C_{D}$ vanishes! Physically, this means that the momentum flux that enters the hemisphere over one-half its surface area leaves it over the other half. Thus the equation describing the behavior of the sound field follows by differentiating Eq. (22) with respect to time and substituting the boundary conditions defined by Eqs. (14) and (19) to yield

$$
E \ddot{F}(t)+\varepsilon F(t) \cdot \dot{F}(t)+\alpha E F(t)=-\sin (t)
$$

Equation (23) is a highly simplified model of the time behavior of the sound particle velocity that is pumped into and out of the resonator cavity. Although derived only for particle inflow, it is believed to be valid throughout a cycle for the reasons described earlier. The coefficient $\varepsilon F(t)$ of the second term $\varepsilon F \dot{F}$ represents nonlinear damping, the amplitude of which is proportional to the instantaneous particle velocity. To insure that the damping is always positive, Eq. (23) is rewritten as

$$
E \ddot{F}(t)+\varepsilon|F(t)| \dot{F}(t)+\alpha E F(t)=-\sin (t)
$$

Equation (23a) can be written into a more convenient form by introducing the function $G(t)$ defined as

$$
G(t) \equiv \sqrt{\varepsilon} F(t)
$$


Substitution of Eq. (24) into Eq. (23a) and introducing Eq. (20) for $\alpha$ yields

$$
|G(t)| \dot{G}(t)+\tilde{E}\left[\ddot{G}(t)+\sqrt{8 C_{D}}\left(\frac{d_{e}^{*}}{d^{*}}\right)\left(\frac{\omega_{\text {res }}^{*}}{\omega^{*}}\right)^{2} G(t)\right]=-\sin (t)
$$

where

$$
\tilde{E} \equiv \frac{E}{\sqrt{\varepsilon}}=\sqrt{\frac{C_{D}}{8} \frac{\rho^{*}\left(\omega^{*} d^{*}\right)^{2}}{P_{i}^{*}}}
$$

The last term on the RHS of Eq. (26) follows from Eq. (8). With regard to Eq. (25), the only way the effect of grazing flow is present is through the discharge coefficient $C_{D}$. This will be clarified in Section 3. Otherwise, Eq. (25) depends upon the amplitude and frequency of the incident sound and the resonator geometry. Equation (25) is nonlinear. This is consistent with the sketches of the particle inflow behavior shown in Figs. (2) and (3) which shows that it separates at the orifice lip. Here the separation is characteristic of a nonlinear Bernouilli type of flow. It is important to note that the model predicts that one of the effects of grazing flow is to generate a nonlinear flow field near the resonator orifice. This is valid providing the steady and acoustic flow fields can be characterized as inviscid and incompressible.

Equation (25) was solved numerically. The computational procedure consisted of numerically integrating it to sufficient1y large values of time until a dynamically stable solution was achieved. Standard Fourier analysis followed to match the frequency component of the particle velocity field to the incident sound pressure frequency. Numerical resul.ts are presented in terms of the standard Fourier components $a_{1}$ and $b_{1}$ defined below as

$$
a_{1} \equiv \frac{1}{\pi} \int_{-\pi}^{\pi} F(t) \cos t d t ; b_{1} \equiv \frac{1}{\pi} \int_{-\pi}^{\pi} F(t) \sin t d t
$$
Curve fits of the computations of $a_{1}$ and $b_{1}$ are
$a_{1} \simeq 1.57 ; b_{1} \simeq \frac{E}{\sqrt{\varepsilon}}\left\{2.07-0.43 \ln \left(\frac{E}{\sqrt{\varepsilon}}\right)-\alpha\left[3.7-2.63\left(\frac{E}{\sqrt{\varepsilon}}\right)^{1 / 3}\right]\right\} \quad(28 a, b)$ 
The curve fit $a_{1} \simeq 1.57$ is quite accurate, to within $5 \%$ over the entire range of the parameters $a$ and $E / \sqrt{\varepsilon}$ tested. Figure 4 shows a comparison between the curve fit to $b_{1}$ defined by Eq. (28b) and the numerical results. The curve fit is quite accurate for $\alpha<2$ and $E / \sqrt{\varepsilon}<1$.

Written in complex notation where it is understood that only the real part has physical meaning, the numerical solution to Eq. (25) is written

$$
F(t) \simeq \frac{e^{i t}}{\sqrt{\varepsilon}}\left(1.57-i b_{1}\right)
$$

The sound particle velocity follows directly by combining Eqs. (9) and (29) to yield

$$
u(r, t) \simeq \frac{-e^{i t}}{r^{2} \sqrt{\varepsilon}}\left[1.57-i\left(b_{1}\right)\right]
$$

With the sound particle velocity specified, the cavity pressure is predicted by Eq. (19). Noting that nondimensionally $P_{i}=e^{i t}$ and $\partial / \partial t=i$, the ratio $P_{C}^{*} / P_{i} *$ is approximately

$$
\frac{P_{c}^{*}}{P_{i}^{*}} \simeq \frac{-E \alpha}{\sqrt{\varepsilon}}\left[b_{1}+i(1.57)\right]
$$

The absolute value $\left|\mathrm{P}_{\mathrm{C}}^{*} / \mathrm{Pi}^{*}\right|$ and relative phase shift across the orifice between $P_{C} *$ and $P_{i}{ }^{*}$ follows from Eq. (31) to be respective$1 y$,

$$
\begin{aligned}
& \left|\frac{P_{c}^{*}}{P_{i}^{*}}\right| \simeq \frac{E \alpha}{\sqrt{\varepsilon}} \sqrt{(1.57)^{2}+\left(b_{1}\right)^{2}} \\
& \tan \phi_{i c} \simeq \frac{-1.57}{b_{1}}
\end{aligned}
$$

Assuming that $\left|b_{1}\right|^{2} \ll(1.57)^{2}$, Eq. (32) simplifies to

$$
\left|\frac{P_{c}^{*}}{P_{i}^{*}}\right| \simeq \frac{1.57 E \alpha}{\sqrt{\varepsilon}}=1.57 C_{D}\left(\frac{\omega_{\text {res }}^{*}}{\omega^{*}}\right)^{2} \sqrt{\frac{\rho^{*}\left(\omega^{*} d_{e}^{*}\right)^{2}}{P_{i}^{*}}}
$$


With the velocity field specified by Eq. (30), the predicted values of the resistance and reactance of Helmhoitz resonators are derived below. The concept of acoustic impedance refers to the relationship between sound pressure and velocity at a particular frequency. Thus, if the acoustic impedance refers to the driving frequency of the sound pressure, the fundamental harmonic frequency component of the velocity normal to the cavity has to be determined. According1y the acoustic impedance of the resonator is defined below as the (complex) ratio of the sound pressure incident to the orifice to the orifice area averaged normal sound particle velocity,

$$
Z_{0}^{*} \equiv \frac{P^{*}\left(r^{*} \rightarrow \infty, t^{*}\right)}{C_{D} u^{*^{\prime}}\left(r^{*}=L_{e}^{*}, t^{*}\right)}=\frac{P_{i}^{*}}{C_{D} u_{v c}^{* 1}} \cdot \frac{p(r=\infty, t)}{u(r=1, t)}=\frac{\rho^{*} V_{\infty}^{*} e^{i t}}{F(t)}
$$

Substituting. Eq. (29) for $F(t)$, Eqn. (8) for $\varepsilon$ and noting that $\mathrm{P}_{i}{ }^{\prime}(\mathrm{r} \rightarrow \infty, t)=\mathrm{e} i \mathrm{t}$, the impedance may be written

$$
z_{0}^{*}=\frac{\rho^{*} V_{\infty}^{*} \sqrt{\varepsilon}}{1.57-i\left(b_{1}\right)}=\frac{\sqrt{\rho^{*} p_{i}^{*}}}{c_{D}} \cdot \frac{1.57+i\left(b_{1}\right)}{(1.57)^{2}+\left(b_{1}\right)^{2}}
$$

The normalized orifice area-averaged resistance and reactance becomes approximately

$$
\frac{R_{0}^{*}}{\rho^{*} c^{*}} \simeq \frac{1}{1.57 C_{D}} \sqrt{\frac{P_{i}^{*}}{\rho^{*} c^{* 2}}}
$$

and

$$
\frac{x_{t}^{*}}{\rho^{*} c^{*}} \simeq \frac{\omega^{*} d^{*}\left\{2.07-0.43 \ln \left(\frac{E}{\sqrt{\varepsilon}}\right)-\alpha\left[3.7-2.63\left(\frac{E}{\sqrt{\varepsilon}}\right)^{1 / 3}\right]\right\}}{(1.57)^{2} c^{*} \sqrt{8 C_{D}}}
$$

The only unknown in the above impedance equations is the discharge coefficient $\mathrm{C}_{D}$. Further interpretation of the impedance as defined by Eqs. (37) and (38) is deferred until experimental measurements of $C_{D}$ are described below.

\section{SINGLE ORIFICE MEASUREMENT PROGRAM}

The two microphone method used by Dean, Hersh and Walker, and others is ideally suited to measure both the effect of grazing flow on the impedance of Helmholtz resonators and the discharge 
coefficient. The two microphone method is described in Section 3.1 below. Its application to mcasure discharge coefficient is described in Section 3.2 . The single orifice semi-empirical impedance model is described in Section 3.3. Two cases of special interest are described in section 3.4 and 3.5 . They deal with, respectively, the acoustic behavior of very long orifice necks and the self-noise generated by Helmholtz resonators exposed to grazing flows.

\subsection{Two-Microphone Method}

A schematic of the instrumentation and test set-up required to use the two-microphone method is shown in Figure 5. The resonator consists of a cylindrical cavity of diameter $\mathrm{D}^{*}$, depth $L^{*}$, and an orifice of diameter $d^{*}$ and thickness $\tau *$. The resonator system occupies one wall of the $0.127 \mathrm{~m}$ by $0.254 \mathrm{~m}$ test section. Grazing flow speeds up to $85.7 / \mathrm{m}$ sec were generated in the Hersh Acoustical Engineering wind tunnel. For all test velocities considered, the wall boundarylayers were turbulent and closely matched the classical $1 / 7$ th power law velocity profile. A typical velocity profile is shown in Figure 6

The resonator orifice area-averaged resistance $\left(R_{O}^{*} / \rho^{*} C^{*}\right)$ and reactance $\left(\mathrm{X}_{t}^{*} / \rho^{*} \mathrm{C}^{*}\right)$ is written, following Dean ${ }^{4}$, as

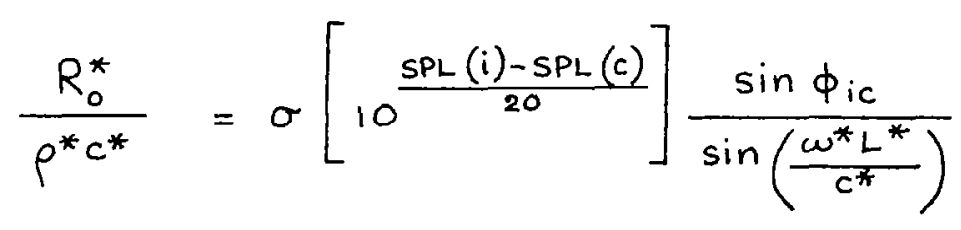

and

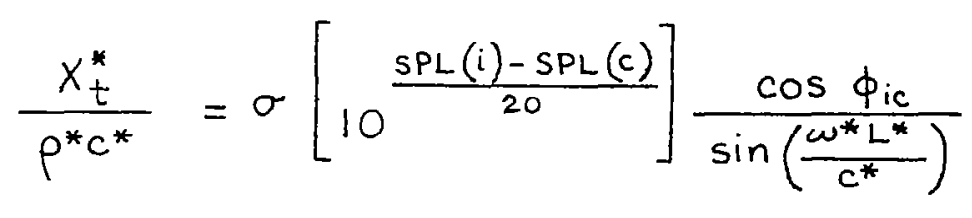

where SPL(i)-SPL(c) represents the sound pressure level difference (in $d B$ ) between the incident sound field and the cavity sound field and $\phi$ ic represents the corresponding phase difference. The radian sound frequency is denoted by $\omega^{*}, c^{*}$ is the cavity local speed of sound and $\sigma$ is the ratio of orifice-to-cavity cross-sectional area. The two-microphone method of measuring impedance requires the simultaneous measurement of the incident and cavity sound pressure levels and their relative phase. These measurements are obtained by flush mounting one microphone at the cavity base and the other flush with the wall containing the orifice as shown 
in Fig. 5. It is important to locate the incident microphone sufficiently far from the orifice to avoid near field effects (measurements indicate that a separation distance of about 4 or 5 orifice diameters is adequate). The microphone should be $10-$ cated sufficiently close, however, so that the separation distance is small relative to the incident sound wavelength; this is necessary to insure accurate measurement of the incident sound wave amplitude and phase.

A schematic of the instrumentation used to conduct the experiments is shown in Figure (7). To generate incident sound pressure levels up to $160 \mathrm{~dB}$, a JBL type 2480 driver capable of producing in excess of 10 watts of relatively "clean" acoustic power is used as the sound source. The .051m diameter driver throat is coupled to the test section by means of a .051m to .102m diameter exponential expansion, JBL type H-93. Sound pressure levels in excess of $150 \mathrm{~dB}$ exceed the input capability of the GR 1560-P42 preamp. A $10 \mathrm{~dB}$ microphone Attenuator, GR Type 1962-3200 has been added, which extends the measurement range accordingly.

The signal generated by the Heath 1G-18 audio generator is amplified by the McIntosh MC2100 100 watt/channel power amplifier to power the JBL driver. The audio generator provides a tracking signal for the AD-YU Synchronous Filter and phase meter system. The 1036 system filters the two microphone input signals to the tracking signal frequency $+2.5 \mathrm{~Hz}$. The AD-YU Type 524A4 Phase Meter reads phase angle be $\bar{t} w e e n$ the signals independent of signal amplitudes. The phase angle output is displayed on the AD-YU Type 2001 digital volt meter. A General Radio-1564 1/10 octave filter together with a Heath Type IM2202 DVM is used to record the output signals from each of the two microphones. Also the two signals are observed on a Tektronix 533 Oscilloscope to visually note approximate phase and distortion effects.

The output of the incident microphone channel of the synchronous filter is used as a control voltage for an automatic level control amplifier. This control amplifier adjusts the drive level to the power amplifier in such a way as to keep the incident level constant, independent of frequency and amplitude response irregularities in the loudspeaker and tunnel.

As a convenience, a triple ganged $5 \mathrm{~dB}$ per step ladder attenuator is used to simultaneously increase the power amplifier drive level and decrease the synchronous filter input signals so that the control loop of the automatic level control amplifier always has the same gain. This has the added advantage of keeping the levels at the AD-YU Filter input constant for all testing levels. Since the AD-Yu Filter displays a small amplitude-phase dependency, this improves accuracy as well as speed of data acquisition. A test of both microphones mounted flush in the wind tunnel wall showed phase tracking within $\pm .2^{\circ}$ over a sound pressure level range of 70-150dB. 


\subsection{Determination of $C_{D}$}

As described in Section 3.1 the two-microphone method measures separately the relative amplitudes and phases of the incident and cavity sound pressure fields. Equation (34) shows that for $\left|b_{1}\right|^{2}<<(1.57)^{2}$, the amplitude $\left|P_{C}^{*} / P_{1}^{*}\right|$ as shown below,

$$
C_{D} \simeq \frac{1}{1.57}\left(\frac{\omega^{*}}{\omega_{\text {res }}^{*}}\right)^{2}\left|\frac{P_{c}^{*}}{P_{i}^{*}}\right| \sqrt{\frac{P_{i}^{*}}{\rho^{*}\left(\omega^{*} d_{e}^{*}\right)^{2}}}
$$

Although Eq. (41) indicates that $C_{D}$ varies in a very complicated way with the incident sound pressure amplitude and frequency as well as with resonator geometry (through $\omega^{*}$ res and $d^{*}$ ), it will be shown below that it is independent of frequency. This follows because the sound particle flow is almost incompressible near the orifice - thus it adjusts virtually instantaneously to changes in frequency. The data shows for a fixed incident amplitude $\mathrm{P}_{i}{ }^{*}$, that

$$
\left|P_{c}^{*} / P_{i}^{*}\right| \sim\left(\omega^{*}\right)^{-1}
$$

Replacing $\left|\mathrm{P}_{\mathrm{C}} * / \mathrm{P}_{\mathrm{i}} *\right|$ by this expression, it follows immediately that $C_{D}$ is independent of frequency.

The two microphone method was used to measure the impedance of a total of sixteen resonator geometries. A list of the resonator geometries tested is summarized in Table I. The orifice diameters tested ranged from 0.914 millimeters ( $\left.0.036^{\prime \prime}\right)$ to $7.137 \mathrm{millimeters}\left(0.28^{\prime \prime}\right)$. The data is summarized in Appendix A.

Before applying Eq.(41) to the two-microphone data, it will prove instructive to derive a simple steady state prediction model (since $C_{D}$ is presumed to be independent of time) of the effect of grazing flow on $C_{D}$. Consider the steady-state pumping of grazing flow into an orifice as shown schematically in Fig.(8). Let $\Delta p^{*}$ be the driving pressure difference across the orifice of area $S_{0}$ * Application of conservation of momentum flux in the vertical direction yields

$$
\underbrace{S_{0} \Delta p^{*}}=\underbrace{\left(p^{*} S_{\infty}^{*} V_{\infty}^{*}\right)} \cdot \underbrace{u_{v c}^{*}}
$$

vertical force
acting on
fluid grazing flow vertical momentum
mass flux flux per unit mass
deflected
into orifice 
Assuming one-dimensional motion in the stream tube shown, application of Bernouilii's equation connects $\Delta p^{*}$ and $u^{*} v c$ as follows

$$
\Delta p^{*}=\frac{1}{2} \rho^{*} u_{v c}^{* 2}
$$

Combining Eqs. (42) and (43) yields

$$
\sqrt{\frac{\Delta p^{*}}{\rho^{*} V_{\infty}^{* 2}}}=\frac{S_{\infty}^{*}}{S_{0}^{*}}
$$

Equations (43) and (44) provide a physical interpretation of how the grazing flow affects the amount of fluid deflected into the orifice. For $\Delta p^{*}$ fixed, Eq. (43) shows that the penetration speed $u_{v}$ c into the orifice is fixed. Equation (44) shows that as the grazing flow speed $V_{\infty}^{*}$ is increased, the grazing flow stream tube area $S_{\infty}^{*}$ and hence the mass flux deflected into the orifice decreases in proportion to $1 / V_{\infty}^{*}$. This interpretation will have a direct analogue in the acoustic application discussed 1ater. Now assume that the grazing flow stream tube area $S^{*}$ is proportional to $S^{*} v c$, the orifice vena contracta area (see Fig. 8). Then, it follows that

$$
C_{D} \equiv \frac{S_{V c}^{*}}{S_{0}^{*}} \sim \sqrt{\frac{\triangle p^{*}}{\rho^{*} V_{\infty}^{* 2}}}
$$

The connection between the steady-state and acoustic discharge coefficients can now be made providing the steady-state driving pressure $\Delta \mathrm{p}^{*}$ is replaced by the amplitude of the incident sound pressure, $P_{i}{ }^{*}$. Thus the acoustic discharge coefficient data should be correlated by plotting $C_{D}$ vs $\sqrt{\mathrm{P}_{i}^{*} / \rho^{*} V^{2}}{ }^{*}$. In Figures 9 (a-e) which represent typical data, plotting $\mathrm{C}_{D}$ vs $\sqrt{P_{i}^{*} / \rho^{*} V_{\infty}^{* 2}}$ collapses the data remarkably weil.

Each resonator was tested at its resonant

frequency. This was determined experimenta11y by setting $V_{\infty}^{*}=0$, $P_{i}^{*}=70 \mathrm{~dB}$ and seeking the frequency for which the phase differences between the incident and cavity sound pressure fields were 90 degrees. Thus $\omega^{*}=\omega^{*}$ res for all values of $P^{*}{ }_{i}$ and $V_{\infty}^{*}$.

The correlation of the data in terms of $C_{D}$ can be rough1y divided into three regimes, defined in terms of the correlation parameter $\sqrt{\mathrm{P}_{i}^{*} / \rho^{*} V^{* 2}}$. To simplify the expression, the parameter $\eta$ is introduced defined below as 


$$
\eta \equiv \sqrt{\frac{P_{i}^{*}}{\rho^{*} V_{\infty}^{*}}}
$$

The three regimes are loosely defined as Regime (1) $\quad \eta<0.2$ wherein $C_{D}$ is linearly related to $n$, Regime (3) $n>1$ wherein $C_{D}$ is constant and Regime (2), $0.2<n<1$ wherein $C_{D}$ is undergoing transition between Regimes (1) and (3).

The correlation of the data summarized in Figs. 9 (a-e) show that in Regime $1, C_{D}$ decreases as $V_{\infty}^{*}$ increases (for a fixed incident sound field). This is equivalent, physically to a reduction of the vena contracta area for increasing $V_{\infty}{ }^{*}$. An equivalent interpretation is that less and less sound particle volume flow is pumped into and out of the cavity as the grazing flow increases. This interpretation is consistent with the flow visualization studies of Baumeister and Rice. It also suggests a simple interpretation of the effects of the grazing flow boundary layer. For very high values of $V_{\infty}{ }^{*}$, the small values of $C_{D}$ suggest that only the local grazing flow near the wall is deflected into the orifice. Thus the effect of the boundary layer should be important. The derivation of the model solution assumed that the grazing flow profile was uniform. To account for boundary-layer effects, it appears reasonable to assume that the data correlates in terms of the ratio $\left(\delta_{\mathrm{BL}}{ }^{*} / \mathrm{d}^{*}\right)$ where $\delta_{\mathrm{BL}}{ }^{*}$ is the grazing flow boundary layer thickness and $\mathrm{d}^{*}$ is the orifice diameter. The idea here is that for a given boundary-layer thickness, the smaller orifice diameter should result in a reduced local grazing flow speed being deflected into the orifice. According to the data, a reduction of the grazing flow speed increases both the correlation parameter $\sqrt{P_{i}^{*} / p^{*} V_{\infty} *^{2}}$ and $C_{D}$. Pursuing this idea, Figure (10) shows the effect of plotting the slope $\mathrm{dC}_{\mathrm{D}} / \mathrm{d} \eta \mathrm{vs}\left(\delta_{\mathrm{BL}} * / \mathrm{d}^{*}\right)$ for the sixtecn orifice specimens defined in Table I. A least square fit to the Regime 1 data is

$$
c_{D} \simeq\left[1.19+0.11^{\delta_{B L}^{*}} / d^{*}\right] \sqrt{P_{i}^{*} / \rho^{*} V_{\infty}^{* 2}} \text {; valid in Regime } 1
$$

It was initially thought that the scatter of the data shown in Fig. (10) was due to the effect of the orifice thickness $\tau^{*}$. However, plotting the ratio of $\mathrm{dCD}_{\mathrm{D}} / \mathrm{d} n$ vs $\tau^{*} / \mathrm{d}^{*}$ showed that this parameter is not important at least for $\tau^{*} / d^{*}<1$. Since $\tau * / d<1$ for all orifices considered in Table $I$, the effect of large $\tau * / \mathrm{d}^{*}$ may still be important. This is discussed in Section 3.4 below. The scatter in the data may be due to errors in measuring the ratio $\left|P_{C} * / P_{i} *\right|$. Recall from Eq. (41) 
that $C_{D}$ was determined in part, by measuring the ratio $\left|P_{C} * / P_{i}^{*}\right|$. An error in measuring the sound pressure level within the cavity of only $0.4 \mathrm{~dB}$ caused by say, a very small leak in the cavity, would result in an error of $5 \%$ in predicting $\mathrm{C}_{\mathrm{D}}$. In this regard the lack of correlation of the data with ' $\mathrm{F} / \mathrm{d}^{*}$ and the correlation with $\left(\delta^{*} / \mathrm{d}^{*}\right)$ suggests that $\mathrm{Eq} .(47)$ is reasonable.

A very simple empirical expression is presented below that correlates the $\mathrm{C}_{D}$ data over the entire grazing flow velocity range,

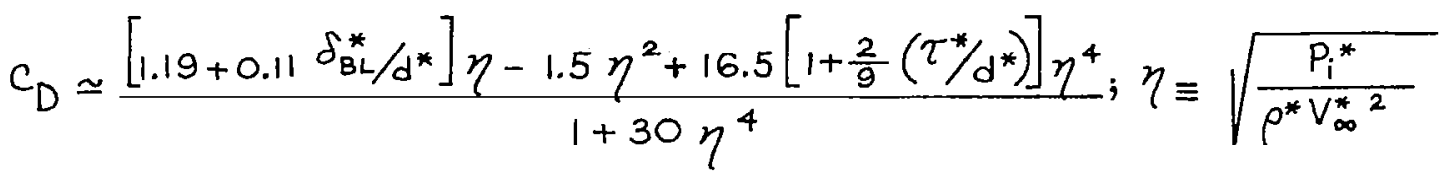

The accuracy of using Eq. (48) to predict $C_{D}$ is shown in Figs. 9 (a-e). There is nothing unique about the magnitudes $1.5,16.5$ and 30 of the coefficients in Eq. (48). They just seem to fit the data "somewhat better" than other values.

With $C_{D}$ defined, the 1 imitations of the parameters $E, \varepsilon$ and $E / \sqrt{\varepsilon}$ introduced in the derivation of the model solution can now be examined. Recall that in the derivation of the resonator impedance, the constraints placed on the parameters $E$ and $\varepsilon$, as defined by Eqs. (10) and the discussion preceeding Eq. (41), are

$$
C_{D} M_{\infty} \ll 1 ;\left(C_{D} M_{\infty}\right)^{2} E \ll 1 ; \frac{E}{\sqrt{\varepsilon}} \ll 1 ;\left|b_{1}\right|<(1.57) \quad(49 a, b, c)
$$

The constraints defined by Eqs. $(49 \mathrm{a}, \mathrm{b})$ were imposed in simplifying Eq. (6), the continuity equation. Replacing $\mathrm{C}_{\mathrm{D}}$ by Eq. (47) for large $V_{\infty}{ }^{*}(\operatorname{smal1} n)$,

$$
C_{D} M_{\infty} \simeq\left[1.19+0.11\left(\delta_{B L}^{*} / d^{*}\right)\right] \sqrt{P_{i}^{*} / \rho^{*} c^{* 2}} \ll 1 \text { for } P_{c}^{*} \ll \rho^{*} c^{* 2}
$$

Assuming $\rho^{*} \simeq 1.2 \mathrm{Kg} / \mathrm{m}^{3}$ and $c^{*} \simeq 340 \mathrm{~m} / \mathrm{sec}$, then the constraint that $\mathrm{P}^{*<<\rho^{*} \mathrm{C}^{* 2}}$ is satisfied for $\mathrm{P}_{i} * 160 \mathrm{~dB}$ which is representative of jet engine turbo-machinery noise. The second constraint, $\left(C_{D^{M}}\right)^{2} E<<1$ is easily satisfied. Assuming the following typical aircraft type values of $\mathrm{P}^{*}{ }_{i}=160 \mathrm{~dB}, \mathrm{f}^{*}=1000 \mathrm{~Hz}, \mathrm{~d}^{*}=\delta_{\mathrm{BL}}{ }^{*}=5 \mathrm{~mm}$ yields 


$$
\left.\left(C_{D} M_{\infty}\right)^{2} E \ll \mid \text { for } V_{\infty}^{*}\right\rangle \mid \text { meter } / \mathrm{sec}
$$

Assuming the above typical values and further assuming $V_{\infty}$ * to be large so that $C_{D} \simeq 0(.1)$, it is also straight forward to demonstrate that the constraint imposed by Eq. (49c) is satisfied for most aircraft type applications.

With $C_{D}$ specified, Figures $11(\mathrm{a}-\mathrm{e})$ compare the predicted phase shift across the orifice based on Eq. (33) with measured data. The resonator geometries are the same ones used in Figs. $9(\mathrm{a}-\mathrm{e})$. In general, the comparison is only fair with errors generally less than about $15 \%$ at the high grazing flow speeds. The general shape of the predicted $\phi_{i c}$ vs $V_{\infty} *$ curves are in good agreement with measurement - particula $\stackrel{\infty}{\mathrm{r}} \mathrm{ly}$ the cross-over between the $P_{i}^{*}=120 \mathrm{~dB}$ and $P_{i}^{*}=130 \mathrm{~dB}$ data. At the $10 \mathrm{w}$ to moderate values of $V_{\infty}{ }^{*}$, the model solution becomes fairly inaccurate with errors as high as $25 \%$. This will be shown later to be quite serious with regard to predicting reactance because Eq. (40) shows it to be proportional to cos $\phi_{i c}$. For the same reasons, resistance, proportional to sin $\phi_{i c}($ see Eq. 39), is predicted accurately.

The poor agreement between predicted and measured phase shift across the orifice is believed to be related to the inaccuracy of the curve fit (Eq. 28b) of the numerical solution of Eq. (25). At low, values of $V_{\infty}{ }^{*}$, Figs. $9(a-e)$ shows that

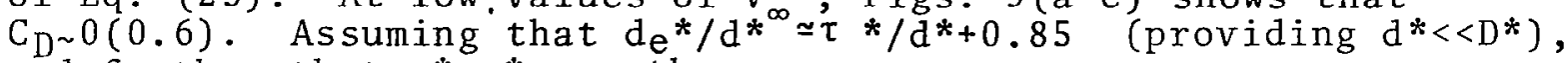
and further that $\omega^{*}=\omega^{*}$ res, then

$$
\alpha \simeq 2.2\left[\tau^{*} / d^{*}+0.85\right]>2
$$

From Fig 4, it is clear that Eq. (28b) becomes increasingly inaccurate as $\alpha$ becomes much larger than 2. At high values of $\mathrm{V}_{\infty}{ }^{*}$, however, $\mathrm{C}_{\mathrm{D}} \simeq 0(.1)$ and $\alpha$ becomes

$$
\alpha \simeq 0.9\left[\tau^{*} / d^{*}+0.85\right]<2 \text { for } \tau^{*} / d^{*}<1.4
$$

The inequality described by Eq. summarized in Table I. This is for the more accurate agreement dicted and measured phase shift
(53) is satisfied for the resonators believed to be the principal reason at high values of $V_{\infty}{ }^{*}$ between preshown in Figs. $11\left(\begin{array}{c}\infty \\ \mathrm{a}-\mathrm{e}\end{array}\right)$. 
Implicit in the derivation of the empirical expression for the discharge coefficient is the assumption that it is independent of frequency. From Eq. (41), this assumption requires that the ratio $\left[\mathrm{P}_{c^{*}} / \mathrm{P}_{i}\right.$ | vary inversely with frequency for a fixed incident sound fiêld and grazing flow speed. This is verified in Fig. (12a) for $\mathrm{P}_{i}^{*}=120 \mathrm{~dB}$ and $\mathrm{V}^{*}=60 \mathrm{~m} / \mathrm{sec}$. A comparison between predicted based on eqs. ( $28 \mathrm{~b})$ and ( $\left.33^{\circ}\right)$ and measured phase shift $\phi_{i c} v s_{\text {frequency is }}$ shown in Fig. 12b. The raw data is summarized in Appendix $B$.

\subsection{Comparison Between Predicted and Measured Impedance}

With $C_{D}$ specified by Eq. (48), substitution into Eqs. and (38) yields semi-empirical predictions of the effects of grazing flow on the normalized orifice area-averaged impedance of single orifice Helmholtz resonators. Figures 13 (a-e) show typical comparisons between predicted and measured values of impedance. Good agreement to within $10 \%$, is shown between predicted and measured resistance. This accuracy is consistent with the accuracy of predicting $C_{D}$ as shown in Figs. 9 (a-e). The agreement between predicted and measured reactance, however, is not as good. The larger percent errors shown arise from relatively smal1 errors in predicting the phase shift $\phi_{i c}$ across the orifice. Referring to Eqs. (39) and (40), small errors in measured $\phi_{i c}$ for values near 90 degrees only negligibly affect measured resistance which is proportional to sin $\phi_{i}$. They significant1y affect measured reactance, however, which is proportional to cos $\phi_{i c}$. The important point here is that both data and model prediction show that reactance remains small as $\mathrm{V}_{\infty}{ }^{*}$ becomes very large. Thus for large value of $\mathrm{V}_{\infty}{ }^{*}$, resistance is much larger than reactance.

The behavior of the Helmholtz resonator at very large values of $V_{\infty}^{*}$, is of special interest for aircraft applications where often ${ }^{\infty} \mathrm{V}_{\infty}^{*}$ is of the order of 150 meters/second $(\simeq 500$ $\mathrm{ft} / \mathrm{sec}$. At these speeds $\mathrm{C}_{\mathrm{D}}$ is defined by Eq. (47). The corresponding orifice area-averaged resistance and reactance simplify to

$$
\frac{R_{0}^{*}}{\rho^{*} c^{*}} \simeq \frac{M_{\infty}}{1.87+0.17\left(\delta_{B L}^{*} / d^{*}\right)}
$$

$\frac{x_{t}^{*}}{\rho^{*} c^{*}} \simeq \frac{0.14 \frac{\omega^{*} d^{*}}{c^{*}}\left\{2.07-.43 \ln (E / \sqrt{\varepsilon})-\alpha\left[3.7-2.63(E / \sqrt{\varepsilon})^{1 / 3}\right]\right\}}{\sqrt{1.19+0.11\left(\delta^{*}{ }_{B L} / d^{*}\right)}}$

The resistance as predicted by Eq. (54) is in excellent agreement with the theoretical value of $M_{*} / 2$ predicted by Rice for the case of uniform flow wherein $\delta_{\mathrm{BL}} * 0$. 
The normalized resistance, defined by Eq. (54), is independent of the incident sound pressure field. The normalized reactance, however, weakly depends upon the incident sound field through the parameters $E / \sqrt{\varepsilon}$ and $\alpha$ as shown in Eq. (55). Since $\left|R_{0}^{*} / \rho^{*} c^{*}\right| \gg>X_{t}^{*} / \rho^{*} c^{*} \mid$ at high grazing flow speeds, it is reasonable to conclude that the impedance of Helmholtz resonators exposed to high grazing flows are almost linear.

Figure (14) shows the effect of variations of incident sound frequency on the discharge coefficient and resonator impedance. The tests were conducted with $P_{i}^{*}=120$ dB and $V_{\infty}^{*}=60$ meters/sec. Both the discharge coefficient and the resonator resistance are seen to be independent of frequency in accord with Eqs. (48) and (54). The data varies less than 5\% from its average value over the frequency range from 350 to $1000 \mathrm{~Hz}$. Good agreement is also shown between predictcd via Eq. (55) and measured reactance. The raw data is summarized in Appendix $B$.

With regard to the effect of grazing flow on resonator reactance, Figs 13 (a-e) show that relative to its zero grazing flow values, the reactance is initially reduced (i.e., more negative) then increased. For each resonator, the resonant frequency was determined by setting $\mathrm{P}_{i}^{*}=70 \mathrm{~dB}$ and seeking the frequency at which $\phi_{i c}=90$ degrees. Since the two-microphone method assumes the cavity reactance to be constant, independent of both the incident sound pressure and grazing flow, the change in reactance is believed to be connected to the orifice inertial reactance $\left(X_{\circ}{ }^{*}\right)$. At low levels of incident sound, say $P_{i}{ }^{*}=70 \mathrm{~dB}$ and at $V_{\infty}^{*}=0$, orifice inertial reactance is defined as the difference between the total resonator reactance $\left(X_{t} * / \rho^{*} c^{*}\right)$ and the cavity stiffness reactance $\left(X^{*}{ }_{\mathrm{cav}} / \rho^{*} \mathrm{C}^{*}\right)$,

$$
\frac{x_{0}^{*}}{\rho^{*} c^{*}} \equiv \frac{x_{t}^{*}}{\rho^{*} c^{*}}-\frac{x_{c a v}^{*}}{\rho^{*} c^{*}}=\frac{x_{t}^{*}}{\rho^{*} c^{*}}+\sigma \cot \left(\frac{\omega^{*} L^{*}}{c^{*}}\right)
$$

Using Eq. (56), Figs. $15(\mathrm{a}, \mathrm{b}, \mathrm{c})$ summarize the effects of grazing flow on the orifice inertial reactance of the fifteen resonators tested (resonator \#16 was omitted for convenience in displaying results). The results of all the resonators are presented because of their different behavior patterns. For modest grazing flow speeds, the orifice inertial reactance of the resonators decreased relative to their $V_{\infty}^{*}=0$ values. For very high grazing flow speeds, the orifice inertial reactance data is divided into three groups, one wherein negative values occurred (models \#5, 7 and 9 in Fig. $15 \mathrm{~b}$ and model \#1I in Fig. $15 \mathrm{c}$ ), a second wherein constant or almost constant values occurred 
(models \#1 and 7 in Fig. (15b) and $8,12,13$ and 15 in Fig. (15c) and a third wherein significant increases occurred relative to their minimum values (models \#2, 3, 4,6 and 10 in Fig. 15a). There is no obvious explanation for these behavior differences. The most likely explanation is that they arise from errors in measuring phase differences $\phi_{i c}$ across the orifice. Recall that at high grazing flow speeds, $\phi_{i c}$ is near 90 degrees and from Eq. (40) total resonator reactance is proportional to $\cos \phi_{\text {ic }}$ which is very sensitive to measurement errors of $\phi_{\text {ic }}$.

Ingard and Ising's ${ }^{12}$ hot-wire anemometry investigation of the acoustic behavior of a Helmholtz resonator exposed to intense sound (see Introduction) showed that the resonator orifice inertial reactance decreased to approximately one-half of its very low sound amplitude value. Since the orifice thickness was negligible, they interpreted the decrease in inertia reactance to a decrease in orifice end correction $\delta_{0}$ * caused by separation of the sound particle velocity at the orifice 1 ip. Upon separating from the lip, the sound particle velocity behaves like a Bernouilli jet-like flow blowing away approximately half of the end correction. Although Ingard and Ising's study did not include grazing flow, their idea is pursued herein because of the close connection between the nonlinearity causec by intense sound pressure amplitudes and the nonlinearity caused by the grazing flow. Following their approach, the experimental behavior of $\delta_{0}$ for model 14 is shown in Fig. (16) as a function of incident sound pressure level and grazing flow speed. The values of $\delta_{0} *$ shown were determined from the data and the connection defined below between $\delta_{0} *$ and orifice inertial reactance,

$$
x_{0}^{*}=\rho^{*} \omega^{*}\left(\tau^{*}+\delta_{0}^{*}\right)
$$

Figure (16a) shows the decrease in end correction as a function of incident sound pressure level for grazing flow speeds $\mathrm{V}_{\infty}{ }^{*}=0,13.6$ and 58.4 meters/second. For the $\mathrm{V}_{\infty}{ }^{*}=0$ case, $\delta_{0}{ }^{*}$ de creases approximately by $50 \%$ as $P_{i}$ * increases from $70 \mathrm{~dB}$ to 130 dB. This is consistent with the results of Ingard and Ising. Again following Ingard and Ising, if the end correction is divided roughly into equal parts on both sides of the orifice, then the nonlinear jetting blows away one side of the end correction. The effect of grazing flow is summarized in Fig. 16(b). To insure an adequate signal-to-noise (i.e., boundary-layer noise), only values of $\mathrm{P}_{\mathrm{i}}^{*}=120 \mathrm{~dB}$ and $130 \mathrm{~dB}$ are shown. The data shows that grazing flow decreases end correction. Using the phaseology of Ingard and Ising, one might say that the grazing flow "blows 
away the end correction. However, this interpretation is not so obvious as the data indicates that $\delta_{0}$ * decreases by more than $50 \%$. In fact, Fig. 16 (b) shows that for $\mathrm{P}_{i}^{*}=130 \mathrm{~dB}, \delta_{\mathrm{o}}$ * is reduced by more than $85 \%$ between its value at $V_{\infty}^{*}=0$ and its value at $V_{\infty} *=60$ meters/second. A possible explanation suggested by E. $J^{\infty}$. Rice in Reference 8 is that Eq. (57) may not be valid. The contribution of the plate thickness $\rho^{*} \omega^{*} \tau$ may be excessively high because not all of the orifice area contributes as suggested by Fig. (2).

It is important to remind the reader that the above discussion assumes that the cavity stiffness reactance is defined by Eq. (56) and further that it is independent of both grazing flow and sound pressure level. This pressumes that the cavity responds adiabatically to whatever volume flow rate is pumped into and out of it (see Section 2.3). The important point here is that the connection between reduction of reactance $X_{0} * / \rho{ }^{*} *$ and the corresponding reduction of end correction $\delta_{0} *$ is only an interpretation - it has not been proved. It assumes that the reduction of the resonator total reactance is due solely to the loss of orifice reactance and hence via Eq. (57) to a loss of end correction. In contrast, it was argued in Ref. 8 that the reduction in mass reactance due to grazing flow occurs within the flow in the orifice itself. Thus, it is not an additional end correction loss.

With the resonator impedance predicted at high grazing flow speeds by Eqs. (54) and (55), it is possible to estimate the amplitude of the sound particle velocity at the vena contracta. The connection between the resonator impedance and sound particle velocity is defined by Eq. (35), rewritten as

$$
\left|\frac{z_{0}^{*}}{\rho^{*} c^{*}}\right|=\sqrt{\left(\frac{R_{0}^{*}}{\rho^{*} c^{*}}\right)^{2}+\left(\frac{x_{t}^{*}}{\rho^{*} c^{*}}\right)^{2}}=\frac{P_{i}^{*^{\prime}}}{\rho^{*} c^{*} c_{D} u_{v c}^{* \prime}}
$$

Assuming for large $V_{\infty}^{*}$ that $\left|R_{0}^{*} / \rho^{*} c^{*}\right| \gg\left|X_{t} * / \rho^{*} c^{*}\right|$ and substituting Eq. (54) for $\mathrm{R}_{\mathrm{O}}^{*} / \rho^{*} \mathrm{C} *$ yields

$$
\frac{P_{i}^{*}}{\rho^{*} c^{*} c_{D} u_{v c}^{* \prime}} \simeq \frac{V_{\infty}^{*}}{1.57 c^{*}\left(1.19+0.11 \delta_{B L}^{*} / d^{*}\right)}
$$

Solving for $u^{* '} v c$ and substituting Eq. (47) for $C_{D}$, yields

$$
u_{v c}^{*}=1.57 \sqrt{\frac{P_{i}^{*}}{\rho^{*}}}
$$


Thus the maximum velocity in the vena contracta is independent of the grazing flow! This is analogous to the steady-state Bernouilli solution defined by Eq. (43) wherein the amplitude of the incident sound pressure replaces the steady-state driving pressure $\Delta \mathrm{p}^{*}$ across the orifice. Typical $\mathrm{u}^{*}{ }^{\prime}$ vc are $6.4,20.3$ and 64.1 meters/sec for $\mathrm{Pi}^{*}=120,140$ and $160 \mathrm{~dB}$ respective $1 \mathrm{y}$. The orifice area-averaged sound particle velocity amplitude | $u_{0}{ }^{*} \mid$ is linearly related to the grazing flow. By definition and substituting Eq. (47) for $C_{D}$,

$$
\left|u_{0}^{* \prime}\right| \equiv C_{D} u_{v C}^{*^{\prime}}=\left(1.87+0.17 \frac{\delta_{B L}^{*}}{d^{*}}\right) \frac{P_{i}^{*}}{\rho^{*} V_{\infty}^{*}},
$$

$\left|u_{o}^{*}\right|$ decreases inverse1y proportiona1 to $V_{\infty}^{*}$.

The normalized impedance model and data described herein represents orifice area-averaged values. It is customary in industrial applications to define the impedance of Helmholtz resonators relative to the area of the cavity backing. The connection between these two definitions is given below

$$
Z_{c}^{*}=\frac{Z_{0}^{*}}{\sigma}
$$

where $Z_{C} *$ is the impedance defined relative to the cavity crosssectional area and $\sigma$ is the ratio is the ratio of the orifice area to cavity cross-sectional area. In terms of the resonator geometry used in these tests (see Fig. 3), $\sigma=\left(\mathrm{d}^{*} / \mathrm{D}^{*}\right)^{2}$. Thus, by proper selection of $\sigma$, the impedance may be adjustcd to achieve, say, a desired optimum value.

\subsection{Thick Orifices}

The derivation of the semi-cmpirical expression for $C_{D}$, defined by Eq. (48), assumed that the effect of orifice thickness-to-diameter ratios, for values less than unity, is negligible. To explore this further, the results of an experimental investigation of the effects of $\tau^{*} / d^{*}$ on the impedance of a Helmholtz resonator are presented. Six orifice thicknesses were tested, the geometries of which are summarized in Table II. For each resonator tested, the frequency was adjusted to achieve resonance at $\mathrm{P}_{i}^{*}=70 \mathrm{~dB}$ and $\mathrm{V}_{\infty}^{*}=0$. For convenience, test results are summarized in Appendix ${ }^{\infty} \mathrm{C}$. 
Figures $17(a-f)$ summarize the resonator prifice area-averaged impedance data for each configuration as a function of $\mathrm{Pi}^{*}$ and $V_{\infty}$ *. The data shows the resistance to increase linearly with $V_{\infty}$ * even for very thick orifices. The corresponding discharge coefficients $C_{D}$ are shown in Figs. $18(a, b)$. As suspected from the behavior of the resistance, the data collapses for all values of $\tau^{*} / \mathrm{d}^{*}$ by plotting $\mathrm{C}_{\mathrm{D}}$ vs. $\sqrt{\mathrm{P}^{*} / \rho^{*} \mathrm{~V}_{\infty}{ }^{2}}$. The variation with $\tau * / d^{*}$ of the linear part of the $C_{D}$ correlation, valid for sma11 values of $\sqrt{\mathrm{P}_{i}^{*} / \rho^{*} \mathrm{~V}_{\infty} *^{2}}$, is shown in Fig. $19(\mathrm{~b})$. Here, $\mathrm{C}_{D}$ is shown to vary only slightly for $\tau^{*} / d^{*}<1$. It increases initially, reaches a maximum for $\tau * / d^{*}$ slight1y less than unity, then decreases for $\tau * / \mathrm{d}^{*}>1$. The corresponding orificc resistance, shown in $\mathrm{Fig}$. 19 (a) shows $\mathrm{R}_{\mathrm{O}} * / \mathrm{p}^{*} \mathrm{c} *$ to decrease initially with $\tau * / d^{*}$, reach a minimum for $\tau^{*} / \mathrm{d}^{*}$ slight1y less than unity, then increase for $\tau * / d^{*}>1$. Observe that the slope $d\left(R_{0}^{*} / \rho^{*} c^{*}\right) / d\left(\tau * / d^{*}\right)$ is quite insensitive of grazing flow speed.

The following physical explanation is offered. The initial decrease of $\left(R_{0} * / \rho^{*} c^{*}\right)$ with $\left(\tau^{*} / d^{*}\right)$ is believed to be related to an increase in the vena contracta area. This increase in vena contracta area is, in turn, related to the increased orifice thickness which permits partial reattachment of the separated orifice jet-like flow. When the orifice thickness becomes sufficiently large, resistance increases due to, perhaps, a reduction of the vena-contracta area related to the sound particle boundarylayer displacement within the orifice thickness.

Figure (20), valid for $V_{\infty} *=0$ and $P_{i}^{*}=70 \mathrm{~dB}$, shows the effect of $\tau^{*} / \mathrm{d}^{*}$ on the resonant frequency $f_{\mathrm{res}}$, the orifice inertial length $\mathrm{d}_{\mathrm{e}} / \mathrm{d}^{*}$, and the orifice and correction $\delta_{\mathrm{o}} / \mathrm{d}^{*}$. From classical Helmholtz resonator theory, $f_{r e s}{ }^{*}$ and $\mathrm{de}^{*} / \mathrm{d}^{*}$ are related as follows,

$$
\frac{d e^{*}}{d^{*}}=\frac{S_{0}^{*}}{V_{c}^{*} d^{*}}\left(\frac{c^{*}}{\omega_{\text {res }}^{*}}\right)^{2}=\frac{\tau^{*}}{d^{*}}+\frac{\delta_{0}^{*}}{d^{*}}
$$

Equation (63) was used to determine the orifice inertial length $\mathrm{de}^{*} / \mathrm{d}^{*}$ and end correction $\delta_{\mathrm{O}} / \mathrm{d}^{*}$ from measurements of $\mathrm{f}_{\mathrm{res}}$. For low values of $\tau * / \mathrm{d}^{*}$, the orifice end correction contributes most to $\mathrm{de}^{*} / \mathrm{d}^{*}$. Conversely, for large values of $\tau^{*} / \mathrm{d}^{*}$, the orifice thickness contributes most to $\mathrm{de} / \mathrm{d} *$. The behavior of the end correction is of considerable interest. According to Ingard

$$
\frac{\delta_{0}^{*}}{d^{*}} \simeq \frac{0.85}{1-1.25\left(\frac{d^{*}}{D^{*}}\right)}=0.914 \text { for } \frac{d^{*}}{D^{*}}=.056
$$


hence the end correction is independent of orifice thickness. It is clear from Fig. $20(\mathrm{~b})$, that the end correction is very insensitive to the orifice thickness. For larger values of $\tau * / d^{*}$, however, the data shows that $1.7<\delta_{0}^{*} / \mathrm{d}^{*}<2.0$, instead of the 0.914 value predicted by Ingard.

Figure $21(a, b)$ shows the effect of $\tau * / d^{*}$ on reactance and end correction for $P_{i}{ }^{*}=120 \mathrm{~dB}$ and $V_{\infty}{ }^{*}=0$ and $41.2 \mathrm{~meter} / \mathrm{sec}$. Both reactance and orifice end correction increase with increasing $\tau * / d^{*}$. The effect of the grazing flow is not especially important. The reactance data shows it to be of some importance for $\tau * / d^{*}<2$. Figure $21(c, d)$ summarizes explicitly the effects of $V_{\infty}^{*}$ and $\tau^{*} / d^{*}$ on the normalized orifice end correction. The data shows grazing flow to reduce and orifice thickness to increase end correction. For very thick orifices, grazing flow effects become less important.

\subsection{Resonator Self-Noise}

To simplify analysis of the grazing flow data, the acoustic signals were maintained at levels at least $20 \mathrm{~dB}$ above the hydrodynamic noise generated by the turbulent boundary layer. In the process of measuring the turbulent boundary-layer noise, large resonance tones were observed to be excited. These tones are believed to be generated by an interaction between the grazing flow turbulent boundary layer and the cavity volume. Applying the concepts put forthe by Heller and $B 1 i s s^{13}$ and more recently by DeMetz and Farabee ${ }^{14}$, the shear layer formed at the orifice upstream separation point, $\theta=\pi / 2, \phi=0$ is believed to generate a fluctuating mass addition and removal to the resonator cavity. Assuming that the frequency at which this mass addition and remova 1 occurs is proportional to $\mathrm{V}_{\infty}^{*} / \mathrm{d}^{*}$, then hydrodynamic resonance should occur at the acoustic resonant frequency. The idea here is that in the absence of any external sound, and for sma11 $\mathrm{V}_{\infty}{ }^{*}$, the acoustic resistance of the resonator is quite small, hence a hydrodynamically induced fluctuating mass flow into and out of the cavity will be strongly amplified at the acoustic resonant frequency. Table III shows the existence of an average Strouhal number equal to 0.26 defined as

$$
s_{t} \equiv \frac{f_{\text {res }}^{*} d^{*}}{\left(v_{\infty}^{*}\right)_{\text {res }}} \simeq 0.26
$$

for the six resonator cavities tested. According to Rossiter ${ }^{15}$, this type of instability is controlled by acoustic feedback.

Figure 22 shows the response of the fluctuating pressure within the cavity of one of the resonators tested with grazing flow. The broadband shape of the response curve with grazing flow 
speed is what one would expect from a unstable turbulent shear layer. The noise radiated from the resonator orifice was quite loud - it was heard throughout the test laboratory.

For each resonator tested, the grazing flow speed at which hydrodynamic resonance occurred corresponded to the extrapolation of the asymptotic slope of the resistance data $\left[\mathrm{d}\left(\mathrm{R}^{*} \mathrm{o} / \rho^{*} \mathrm{C}^{*}\right) / \mathrm{dV}_{\infty}{ }^{*}\right]$ towards the $R_{0} * / \rho^{*} c^{*}=0$ axis as shown in Figs. $23(a, b, c)$. Along this slope, the sound particles are pumped into and out of the resonator cavity in an essentially inviscid manner by the grazing flow.

The dip (or minimum) of the resistance data shown in Figure 23 (a) can be explained by the hydrodynamic resonance. For $\mathrm{P}_{i}{ }^{*}=120 \mathrm{~dB}$, the dip is observed to occur at a grazing flow speed near the hydrodynamic resonance speed defined by Eq. (65). For incident SPL's sufficiently weak, the cavity pressure will be excessively large due to hydrodynamic resonance and hence the values of $\left|\mathrm{P}_{\mathrm{i}}{ }^{*} / \mathrm{P}_{\mathrm{C}}^{*}\right|$ will be corresponding very small resulting in a local (with grazing flow speed) reduction in resistance (see Eq. 39).

Both the resistance and reactance data shown demonstrate that below the hydrodynamic resonance speed, $\left(\mathrm{V}_{\infty}^{*}\right)$ res, acoustic effects dominate the behavior of the resonator. ${ }^{\infty}$ Above this speed, the grazing flow dominates the resonator behavior.

\section{IMPEDANCE OF CLUSTERED ORIFICES}

Since Helmholtz resonators are often designed with two or more cavities backed by a common cavity, an understanding of the manner in which neighboring orifices interact and affect impedance is of considerable theoretical and practical interest. According$1 y$, the results of an experimental investigation of the impedance of interacting orifices in the presence of high speed grazing flow and intense sound pressure levels are presented.

The data is correlated in terms of an orifice interaction parameter defined below. The data is presented in two parts, one corresponding to zero grazing flow $\left(V_{\infty}^{*}=0\right)$ and weak incident sound $\left(\mathrm{P}^{*}=70 \mathrm{~dB}\right)$ in Section 4.1 and the other to high speed grazing flow and intense sound pressure levels in Section 4.2.

The two-microphone method was used to measure the impedance of the clustered orifices. The results of twenty different orifice configurations are presented. The number of orifices tested ranged from one to sixty-four. The diameters of the orifices were sized so that the percent open area of the orifices was held 
constant, equal to $1.96 \%$. For the single orifice configuration, this corresponds to a diameter $d_{1} *=7.1$ millimeters $(0.28$ inches). The diameter of the other configurations follow from the relationship

$$
d_{N}^{*}=\frac{d_{1}^{*}}{\sqrt{N}}
$$

The resonator geometry consists of a cylindrical cavity of diameter $D^{*}=50.8$ millimeters ( 2 inches) depth $L^{*}=38.1$ millimeters ( 1.5 inches) and an orifice thickness $\tau^{*}=1.020$ mil1imeters (0.040 inches). By maintaining a constant percent open area, it is impossible to verify directly Fok's interaction model (see Introduction). Despite this drawback, it is essential in terms of application of the test results that the effects of the interaction be measured with the percent open area held constant.

A simple interaction parameter is introduced similar to that proposed by Fok. ${ }^{10}$ It is defined as the ratio of the average array spacing $S^{*}$ between neighboring orifice centers and the average orifice diameter $\left(\mathrm{d}^{*} \mathrm{~N}\right), \mathrm{S}^{*} / \mathrm{d}_{\mathrm{N}}{ }^{*}$, where $\mathrm{N}$ refers to the number of orifices backed by a common cavity. S* is defined as the distance between orifice centers. Orifices are obviously independent whenever $S^{*} / \mathrm{d}_{\mathrm{N}}^{*}>>1$. Conversely, interaction should become important whenever $\mathrm{S}^{*} / \mathrm{d}_{\mathrm{N}}^{*}$ is near unity. For convenience; test results are summarized in Appendix $D$.

\subsection{Zero Grazing Flow, Low Sound Amplitude Results}

Table IV summarizes the results of an experimental investigation of the effects of interacting orifices on the impedance of Helmholtz resonators exposed to weak sound waves for the case $\mathrm{V}^{*}=0$. During each test, the frequency of the incident sound field was "tuned" to resonance (zero total reactance) at an incident sound pressure level of $70 \mathrm{~dB}$. Data is presented in terms of resonant frequency $f_{\text {res* }}$, normalized orifice area-averaged resistance $R_{0} * / \rho * c *$ and reactance $X_{t} * / \rho^{*} c *$, normalized orifice inertial length $\mathrm{d}_{\mathrm{e}} / \mathrm{d}_{1}$ * (normalized with respect to the single orifice $(\mathrm{N}=1)$ diameter) and normalized orifice end correction $\delta_{o, N}^{*} / d_{1}^{*}$. The results summarized in Table IV are displayed graphically for convenience in Figs. (24-27).

For a fixed relative spacing between orifices, $S^{*} / \mathrm{d}_{N}^{*}=\mathrm{con}$ stant, the resonant irequency $f_{r e s} *$ is seen in Fig. (24a) to be almost independent of the number of orifices. The measurements indicate that $f_{\text {res }}{ }^{*}$ is a strong function of the relative spacing between orifices. This is shown clearly in Fig. 25(a). It suggests the attractive possibility of tuning different parts of an array of cavity-backed perforates to different frequencies by 
changing their relative spacing to achieve an increased sound absorption bandwidth (at constant percent open area).

The increase in $f_{r e s}^{*}$ with $S^{*} / d_{N}^{*}$ can be explained in terms of a corresponding decreased orifice end correction. Recall from Rayleigh's classical single orifice slug-mass model of the Helmholtz resonator, that the connection between resonator resonant frequency $f_{\text {res }}^{*}$ and single orifice end correction $\delta_{0}^{*}$ is

$$
f_{\text {res }}^{*}=\frac{c^{*}}{2 \pi} \sqrt{\frac{S_{0}^{*}}{V_{c}^{*}\left(\tau^{*}+\delta_{0}^{*}\right)}}
$$

Equation (67) was used to determine the orifice end correction $\delta_{0}^{*}, N / d_{1}^{*}$ of Figs. $24(\mathrm{~b})$ and $25(\mathrm{~b})$. At the suggestion of Dr. E. J. Rice, the data shown in Fig. 25 (b) is replotted in Fig. 25 (c) in terms of $S^{*}$, the array spacing and $\mathrm{dN}_{\mathrm{N}}^{*}$, the local orifice diameter. It is clear that the end correction is only a function of the local orifice diameter and array spacing - it is independent of $N$. A least square fit to the data shows that

$$
\frac{\delta_{0, N}^{*}}{d_{N}^{*}} \sim 0.52+\frac{4.37}{s^{*}}
$$

The above orifice end correction dependance upon $S *$ is consistent with that proposed by Ingard. 9 Ingard's analysis, however, suggested that the end correction was a function of both the separation distance and the number of orifices in contrast to the behavior shown in Fig. $25(\mathrm{c})$ wherein $\delta_{\mathrm{O}}^{*}, \mathrm{~N} / \mathrm{d}$ N is quite insensitive to $\mathrm{N}$. Since $\left(\tau *+\delta_{0}^{*}, N\right) S_{0}^{*}$ is a measure of the volume of mass set into oscillatory motion by the incident sound wave, its increase with decreasing $S^{*}$ indicates that interacting neighboring orifices increase this volume. Mellin ${ }^{11}$ recently proposed an interesting explanation for the increase in $\delta_{0}^{*}, \mathrm{~N}$ due to interacting orifices. He suggested that the increase is due to the decreased relative shear of the fluid in the interior of adjacent orifices. Since the spacings between orifices are very smal1 relative to the incident sound wavelength, the pumping of fluid into and out of the orifices are in phase. Thus the particle motion induced by the sound wave by an adjacent orifice reduces the retarding shear stresses on nearby orifices thereby permitting more mass to be excited by the incident sound and hence a larger orifice end correction.

The effect of interaction among the orifices on resistance is shown in Fig. (26). The behavior is in contrast to that of the end correction in that the orifice area-averaged resistance is very insensitive to the relative spacing between orifices (Fig. 26a) but very sensitive to the number of orifices (Fig. 26b). The data shown suggests that the resistance increases with $N$ in a near linear manner. This is in contrast to the $\sqrt{N}$ increase proposed by Ingard. ${ }^{\circ}$ Figure 27 shows the dependence upon fre- 
quency of the orifice area-averaged resistance of the $N=1,4,16$, 36 and 64 orifice configurations for a constant orifice spacing of $S^{*} / \mathrm{d}_{N}^{*}=2.5$. In al1 cases, the data showed the resistance to be proportional to $\sqrt{f}$ in agreement with classical theory (e.g., see Ingard ${ }^{9}$ ). The data shown in Fig. 26(b) has been corrected to the resonant frequency of the $N=1$ orifice of $f_{\text {res }} * 484 \mathrm{~Hz}$. Since in all cases, $\tau * / \mathrm{dN}^{*}$ is of order unity or less, the effect of orifice thickness is not important and hence was neglected in Fig. $26(\mathrm{~b})$.

\subsection{Effect of Grazing Flow}

Measurements were taken of the effects of grazing flow on the orifice area-averaged impedance of the twenty configurations summarized in Table IV. Representative graphs of the results are summarized in Figs. (28)-(32) for the $N=1,4,16,36$ and 64 orifice configurations. The data shows that for sufficiently high grazing flow speeds, the resistance becomes a linear function of $\mathrm{V}_{\infty}{ }^{*}$, virtually independent of incident sound pressure level. The corresponding values of reactance decreases by modest amounts from its value at $V_{\infty}^{*}=0$. A detailed discussion of all the data is described below.

Figures 28 and $29(\mathrm{a}-\mathrm{d})$ are of particular importance. Figure (28) represents the base line configuration consisting of a single orifice of diameter $d_{1}=7.1 \mathrm{mil1imeters.} \mathrm{Figure} 29(\mathrm{a}, \mathrm{b})$ summarize the effects of grazing flow on the impedance of $\mathrm{N}=4$ orifice configurations ( $d_{4}=3.55$ millimeters) orientated so that a line connecting their centers is perpendicular to the incident grazing flow. The values of the interaction parameter is $S^{*} / \mathrm{d}_{4}^{*=3}$ in Fig. (29a) and $\mathrm{S}^{*} / \mathrm{d}_{4}^{*}=2$ in Fig. ( $29 \mathrm{~b}$ ). The measure ments show the resistance and reactance to be reduced somewhat relative to their values shown in Figure 28 for the $N=1$ configuration. No meaningful impedance changes between these two configurations were measured. On the basis of the limited data shown, orifices, orientated so that a line connecting the centers is perpendicular to an incident grazing flow, operate independently of each other for values of $S^{*} / d_{4}^{*}$ as low as 2 .

Figures $29(\mathrm{c}, \mathrm{d})$ summarize the effects of orientating the four orifices in a direction parallel to the incident grazing flow. No meaningful impedance changes between the parallel and perpendicular orientations were observed for the $S^{*} / d_{4} * 3$ configuration (Figures $29(\mathrm{a}, \mathrm{c})$ ). The data for the $\mathrm{S}^{*} / \mathrm{d}_{4} *=2$ configuration of Fig. 29(d), however, showed a considerable reduction in resistance relative to the $\mathrm{S}^{*} / \mathrm{d}_{4}^{*}=3$ configuration of Fig. 29(b). It also showed a considerable reduction in resistance relative to the $\mathrm{S}^{*} / \mathrm{d}_{4}{ }^{*}=3$ configuration of $\mathrm{Fig}$. 29 (c). The reactance data, particularly the 140 dB incident sound 
pressure level data, also was significantly different relative to the $S^{*} / \mathrm{d}_{4} * 3$ reactance. It appears from an examination of Figures $29(\mathrm{c}, \mathrm{d})$ that interaction among neighboring orifices occurs when $S^{*} / d_{4}^{*}=2$; the orifices appear to behave independent1y when $\mathrm{S}^{*} / \mathrm{d}_{4} *=3$. An important finding from this study is that the effects of grazing flow is important only for orifices orientated in a direction parallel to the grazing flow; it is unimportant for orifices orientated in a direction perpendicular to the grazing flow.

Figures $30(a, b), 31(a, b)$ and $32(a, b)$ represent typical data for the $\mathrm{N}=16,36$ and 64 orifice configurations for array spacings of $\mathrm{S}^{*} / \mathrm{d}_{\mathrm{N}}^{*}=2.5$ and 5.0 . Briefly the data shows resonator resistance to increase 1 inearly with grazing flow speed and reactance to decrease to constant or almost constant values. Figures $33(\mathrm{a}, \mathrm{b}), 34(\mathrm{a}, \mathrm{b})$ and $35(\mathrm{a}, \mathrm{b})$ show that the data can be correlated in terms of an orifice discharge coefficient.

The important effects of grazing flow on the orifice areaaveraged impedance for all twenty configurations tested are summarized in Figs. (36-40). Figure (36) shows the effect of array spacing and number of orifices on resistance for various grazing flow spceds and for an incident sound pressure level $\mathrm{P}_{\mathrm{i}}^{*}=120 \mathrm{~dB}$. While there is some scatter in the data, it is clear that the effects of both array spacing and number of orifices on the resistance of Helmholtz resonators are unimportant. Although not presented, these findings are also valid for other values of incident sound pressure.

Figure(37) summarizes the effect on resonator impedance of increasing number of. orifices for a fixed orifice spacing of $\mathrm{S}^{*} / \mathrm{d}_{\mathrm{N}}^{*}=2.5$. Data is presented at $\mathrm{P}_{\mathrm{i}}^{*}=120$ dB for grazing flow speeds of $\mathrm{V}_{\infty}{ }^{*}=0$ and 70 meters/sec. Figure 37 (a) shows a siight increase in ${ }^{\infty}$ resistance with increasing number of orifices for $V^{*}=0$ and a slight decrease for $V_{\infty}^{*=70}$ meters/second. Figures 39 (b) and (c) also show small changes of reactance and orifice end correction with increasing number of orifices. The orifice end correction data was derived by assuming that the cavity stiffness is independent of grazing flow and incident sound amplitude as discussed in Section 2.2.

Figures (38) and (39) summarize the effects of orifice spacing on resonator reactance and orifice end correction. The data is presented as a function of incident sound pressure levels $\mathrm{P}_{i}{ }^{*}=120,130 \mathrm{~dB}$, grazing flow speeds $\mathrm{V}_{\infty}^{*}=0.70$ meters $/ \mathrm{sec}$ and number of orifices $N=16,36$ and 64 . For $V_{\infty}^{*}=0$, the reactance data exhibits slight scatter; it is virtualiy independent of array spacing. However, there is considerable scatter in the $V_{\infty}^{*}=70$ meters/sec reactance data. No trend in the data is evident. Thus, to first order, array spacing does not appear to significantly affect reactance. 
In contrast to its effect on reactance, the data summarized in Fig. 39 shows orifice end correction to be a strong function of array spacing. It is clear that both number of orifices and incident sound amplitude influence only slightly orifice end correction.

The orifice end correction data of Fig. (39) for the $V_{\infty}{ }^{*}=0$ case is shown replotted in Fig. (40). The data shows end correction to be a function of the local orifice diameter, array spacing and incident sound pressure amplitude. A least square fit to the data for $\mathrm{P}_{i}{ }^{*}=120,130 \mathrm{~dB}$ is respectively

$$
\frac{\delta_{0, N}^{*}}{d_{N}^{*}} \simeq 0.25+\frac{4.27}{S^{*}}
$$

$$
\frac{\delta_{0, N}^{*}}{d_{N}^{*}} \simeq 0.05+\frac{4.30}{S^{*}}
$$

Comparing Eqs. (68), (69) and (70), the coefficients of the terms inversely proportional to array spacing are only weakly dependent upon incident sound amplitude. The intercept terms, on the other hand, are very sensitive to the incident sound amplitude. 


\section{CONCLUSIONS}

With regard to its application to aircraft engines, the most important finding of this study is that at high grazing flow speeds, the acoustic resistance of Helmholtz resonators is almost linearly proportional to the grazing flow speed and almost independent of of the incident sound pressure. The corresponding values of reactance are much smaller than the resistance and tend towards zero for increasing grazing flow speeds. This is true regardless of the number of orifices or the details of the resonator geometry. Because of their insensitivity to the incident sound, the impedance of Helmholtz resonators at high grazing flow speeds is almost

"linear".

The behavior of the reactance requires special comment. Its reduction with grazing flow is "believed to be related to the loss of part of the orifice end correction and to a loss of part of the inertial reactance within the orifice thickness. Due to the vena contracta effect of the grazing flow, a slug-mass type of oscillatory flow no longer exists within the orifice. The above is conjecture at this point - further research is warranted.

Other findings of considerable theoretical and practical interest are:

(1) The amplitudes of the incident and cavity sound fields of Helmholtz resonators in a grazing flow environment have been connected in terms of a discharge coefficient.

(2) For isolated orifices whose thicknesses are smaller than their diameters, a semi-empirical model has been derived, which predicts the effects on impedance of resonator geometry, incident sound amplitude and frequency, grazing flow speed and boundary-layer thickness.

(3) The flow field near the resonator orifice(s) is unsteady and incompressible. This is true regardless of the amplitude of the incident sound pressure providing the grazing flow spced is subsonic.

(4) The response of orifices whose thicknesses are much larger than their diameter are generally less sensitive to grazing flow relative to the response of thin orifices.

(5) Loud resonant tones were observed to radiate from single orifice Helmholtz resonators due to interaction between the grazing flow shear layer and the resonator cavity. The tones occurred at a grazing flow speed defined as ( $V_{\infty}^{*}$ )res $=f_{r e s}^{*} d^{*} / 0.26$ where $f_{r e s}^{*}$ is the resonator classical Helmholtz resonant frequency 
and $\mathrm{d}^{*}$ is the orifice diameter. Measurements show that for grazing flow speeds greater than $\left(V_{o g}^{*}\right)$ res, the grazing flow dominates the resonator behavior and for grazing flow speeds less than $\left(V_{\infty}^{*}\right)$ res, the sound particle velocity field dominates the resonator behavior.

(6) For the case of Helmholtz resonators consisting of multiple orifices in a grazing flow environment, interaction between nearby orifices occurs only for those orifices whose centers were aligned in a direction parallel to the direction of flow. Interaction did not occur for orifices whose centers were aligned perpendicular to the direction of flow. Measurements show resonator resistance and reactance to be only a weak function of the number of orifices and their relative spacing. Orifice end correction, on the other hand, was found to be quite dependent upon orifice spacing. It is fairly insensitive to the number of orifices. These findings are valid with and without grazing flow. 
The two-microphone impedance test data is summarized herein for the sixteen single orifice resonators described in Table $I$. The data is presented in terms of $C_{D}, R_{0}^{*} / \rho^{*} c^{*}$, and $X_{t} / \rho^{*} c^{*}$ for different values of $\mathrm{P}_{i}{ }^{*}$ and $\mathrm{V}^{*}$. They were computed by measuring $\mathrm{P}_{i}^{*}, \mathrm{P}_{C}{ }^{*}$ and $\phi_{i}{ }^{*}$ and substituting these values into Eqs. (39) (40) and (41). The orifice reactance $X_{O}^{*} / \rho^{*} C^{*}$ and end correction can be determined using Eqs. (56) and (57). 
Mode1 \#1 $\quad \mathrm{d}^{*}=.914 \mathrm{~mm} ; \tau^{*}=.508 \mathrm{~mm} ; \mathrm{D}^{*}=19.05 \mathrm{~mm} ; \quad \mathrm{L}^{*}=12.7 \mathrm{~mm} ; \mathrm{T}_{\infty}^{*}=70^{\circ} \mathrm{F}$; $\mathrm{P}_{\infty}^{*}=29.9^{\prime \prime} \mathrm{Hg} ; \dot{f}_{\text {res }}^{*}=600 \mathrm{~Hz}, \mathrm{~d}_{\mathrm{e}}^{*} / \mathrm{d}^{*}=1.859$

\begin{tabular}{|c|c|c|c|c|}
\hline $\begin{array}{c}V_{\infty}^{*} \\
(m e t e r s / \sec )\end{array}$ & $\mathrm{p}_{\dot{i}}^{*}$ & $C_{D}$ & $\mathrm{R}_{\mathrm{o}}^{*} / \rho^{*} \mathrm{C} *$ & $X_{t} * / \rho * c^{*}$ \\
\hline 15.6 & $\begin{array}{l}100 \\
110 \\
120 \\
125 \\
130 \\
135 \\
140 \\
145\end{array}$ & $\begin{array}{r}.215 \\
.335 \\
.420 \\
.461 \\
.493 \\
.516 \\
.534 \\
.545\end{array}$ & $\begin{array}{l}.0093 \\
.0105 \\
.0153 \\
.0190 \\
.0240 \\
.0308 \\
.0400 \\
.0523\end{array}$ & $\begin{array}{l}-.0038 \\
-.0046 \\
-.0053 \\
-.0053 \\
-.0053 \\
-.0052 \\
-.0050 \\
-.0055\end{array}$ \\
\hline 24.7 & $\begin{array}{l}100 \\
110 \\
120 \\
125 \\
130 \\
135 \\
140 \\
145\end{array}$ & $\begin{array}{r}.127 \\
.197 \\
.314 \\
.383 \\
.438 \\
.373 \\
.497 \\
.525\end{array}$ & $\begin{array}{l}.0160 \\
.0184 \\
.0207 \\
.0230 \\
.0271 \\
.0336 \\
.0383 \\
.0543\end{array}$ & $\begin{array}{l}-.0053 \\
-.0062 \\
-.0062 \\
-.0056 \\
-.0053 \\
-.0056 \\
-.0058 \\
-.0060\end{array}$ \\
\hline 33.4 & $\begin{array}{l}110 \\
120 \\
125 \\
130 \\
135 \\
140 \\
145\end{array}$ & $\begin{array}{l}.135 \\
.223 \\
.300 \\
.361 \\
.420 \\
.458 \\
.497\end{array}$ & $\begin{array}{r}.0275 \\
.0297 \\
.0295 \\
.0329 \\
.0380 \\
.0467 \\
.0574\end{array}$ & $\begin{array}{l}-.0069 \\
-.0072 \\
-.0065 \\
-.0061 \\
-.0059 \\
-.0064 \\
-.0069\end{array}$ \\
\hline 40.3 & $\begin{array}{l}110 \\
120 \\
125 \\
130 \\
135 \\
140 \\
145\end{array}$ & $\begin{array}{l}.112 \\
.195 \\
.248 \\
.318 \\
.379 \\
.441 \\
.479\end{array}$ & $\begin{array}{l}.0332 \\
.0341 \\
.0359 \\
.0374 \\
.0421 \\
.0484 \\
.0595\end{array}$ & $\begin{array}{l}-.0072 \\
-.0072 \\
-.0071 \\
-.0066 \\
-.0062 \\
-.0065 \\
-.0072\end{array}$ \\
\hline 54.1 & $\begin{array}{l}110 \\
120 \\
125 \\
130 \\
135 \\
140 \\
145\end{array}$ & $\begin{array}{l}.078 \\
.145 \\
.182 \\
.244 \\
.307 \\
.377 \\
.433\end{array}$ & $\begin{array}{r}.0484 \\
.0464 \\
.0493 \\
.0490 \\
.0520 \\
.0565 \\
.0657\end{array}$ & $\begin{array}{l}-.0088 \\
-.0082 \\
-.0086 \\
-.0081 \\
-.0079 \\
-.0077 \\
-.0088\end{array}$ \\
\hline
\end{tabular}




\begin{tabular}{|c|c|c|c|c|}
\hline $\begin{array}{c}\mathrm{V}_{\infty}{ }^{*} \\
(\operatorname{meters} / \mathrm{sec})\end{array}$ & $\begin{array}{l}\mathrm{P}_{i^{*}}^{*} \\
(\mathrm{~dB})\end{array}$ & $\mathrm{C}_{\mathrm{D}}$ & $R_{o}^{*} / \rho^{*} C^{*}$ & $x_{t} * / \rho * c *$ \\
\hline 65.7 & $\begin{array}{l}110 \\
120 \\
125 \\
130 \\
135 \\
140 \\
145\end{array}$ & $\begin{array}{l}.066 \\
.115 \\
.149 \\
.198 \\
.255 \\
.322 \\
.393\end{array}$ & $\begin{array}{l}.0572 \\
.0588 \\
.0604 \\
.0605 \\
.0628 \\
.0663 \\
.0726\end{array}$ & $\begin{array}{l}-.0082 \\
-.0076 \\
-.0083 \\
-.0083 \\
-.0080 \\
-.0080 \\
-.0086\end{array}$ \\
\hline 77.1 & $\begin{array}{l}110 \\
120 \\
125 \\
130 \\
135 \\
140 \\
145\end{array}$ & $\begin{array}{l}.053 \\
.094 \\
.122 \\
.166 \\
.218 \\
.275 \\
.352\end{array}$ & $\begin{array}{l}.0712 \\
.0722 \\
.0735 \\
.0723 \\
.0734 \\
.0776 \\
.0809\end{array}$ & $\begin{array}{l}-.0093 \\
-.0087 \\
-.0092 \\
-.0093 \\
-.0095 \\
-.0103 \\
-.0106\end{array}$ \\
\hline
\end{tabular}

Mode1 \#2 $\mathrm{d}^{*}=.914 \mathrm{~mm} ; \tau^{*}=.254 \mathrm{~mm} ; \mathrm{D}^{*}=19.05 \mathrm{~mm} ; \mathrm{L}^{*}=25.4 \mathrm{~mm}$

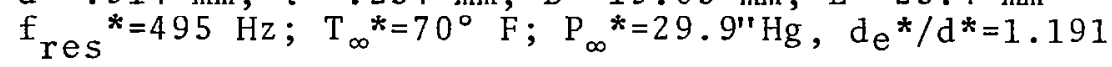

\begin{tabular}{|c|c|c|c|c|}
\hline $\begin{array}{c}\mathrm{V}_{\infty}{ }^{*} \\
(\text { meters } / \mathrm{sec})\end{array}$ & $\begin{array}{l}\mathrm{P}_{i^{*}}^{*} \\
(\mathrm{~d} \mathrm{~B})\end{array}$ & $\mathrm{C}_{\mathrm{D}}$ & $\mathrm{R}_{\mathrm{O}}^{*} / \rho^{*} \mathrm{C}^{*}$ & $x_{t}{ }^{*} / \rho^{*} c^{*}$ \\
\hline 0 & $\begin{array}{r}70 \\
80 \\
90 \\
100 \\
110 \\
120 \\
130 \\
135 \\
140\end{array}$ & $\begin{array}{l}.185 \\
.323 \\
.490 \\
.605 \\
.632 \\
.620 \\
.620 \\
.634 \\
.630\end{array}$ & $\begin{array}{l}.0024 \\
.0024 \\
.0028 \\
.0039 \\
.0065 \\
.0123 \\
.0223 \\
.0291 \\
.0390\end{array}$ & $\begin{array}{c}0 \\
- \\
-.0002 \\
-.0011 \\
-.0023 \\
-.0023 \\
-.0014 \\
-.0009 \\
-.0001\end{array}$ \\
\hline 9.1 & $\begin{array}{r}90 \\
100 \\
110 \\
120 \\
130 \\
135 \\
140\end{array}$ & $\begin{array}{l}.290 \\
.449 \\
.561 \\
.610 \\
.640 \\
.639 \\
.614\end{array}$ & $\begin{array}{l}.0043 \\
.0050 \\
.0073 \\
.0126 \\
.0216 \\
.0289 \\
.0401\end{array}$ & $\begin{array}{l}-.0021 \\
-.0022 \\
-.0027 \\
-.0022 \\
-.0011 \\
-.0006 \\
+.0001\end{array}$ \\
\hline
\end{tabular}




\begin{tabular}{|c|c|c|c|c|}
\hline $\begin{array}{c}\mathrm{V}_{\infty}{ }^{*} \\
(\text { meters/sec })\end{array}$ & $\begin{array}{l}\mathrm{P}_{i} * \\
(\mathrm{~d} B)\end{array}$ & $\mathrm{C}_{\mathrm{D}}$ & $R_{0} * / \rho * c *$ & $x_{t} * / \rho * c *$ \\
\hline 15.2 & $\begin{array}{r}90 \\
100 \\
110 \\
120 \\
130 \\
135 \\
140\end{array}$ & $\begin{array}{l}.141 \\
.225 \\
.372 \\
.553 \\
.617 \\
.639 \\
.625\end{array}$ & $\begin{array}{r}.0093 \\
.0103 \\
.0113 \\
.0144 \\
.0224 \\
.0287 \\
.0394\end{array}$ & $\begin{array}{l}-.0032 \\
-.0036 \\
-.0034 \\
-.0026 \\
-.0017 \\
-.0008 \\
-.0003\end{array}$ \\
\hline 24.4 & $\begin{array}{l}100 \\
110 \\
115 \\
120 \\
125 \\
130 \\
135 \\
140\end{array}$ & $\begin{array}{l}.135 \\
.235 \\
.303 \\
.398 \\
.482 \\
.550 \\
.584 \\
.612\end{array}$ & $\begin{array}{r}.0180 \\
.0183 \\
.0190 \\
.0193 \\
.0214 \\
.0251 \\
.0318 \\
.0402\end{array}$ & $\begin{array}{l}-.0033 \\
-.0034 \\
-.0033 \\
-.0028 \\
-.0022 \\
-.0016 \\
-.0012 \\
-.0006\end{array}$ \\
\hline 39.3 & $\begin{array}{l}100 \\
110 \\
115 \\
120 \\
125 \\
130 \\
135 \\
140\end{array}$ & $\begin{array}{l}.074 \\
.132 \\
.181 \\
.244 \\
.312 \\
.397 \\
.485 \\
.550\end{array}$ & $\begin{array}{l}.0331 \\
.0330 \\
.0322 \\
.0318 \\
.0332 \\
.0348 \\
.0380 \\
.0448\end{array}$ & $\begin{array}{l}-.0028 \\
-.0025 \\
-.0021 \\
-.0021 \\
-.0019 \\
-.0014 \\
-.0008 \\
-.0002\end{array}$ \\
\hline 53.3 & $\begin{array}{l}100 \\
110 \\
115 \\
120 \\
125 \\
130 \\
135 \\
140\end{array}$ & $\begin{array}{l}.057 \\
.098 \\
.131 \\
.173 \\
.229 \\
.308 \\
.393 \\
.488\end{array}$ & $\begin{array}{r}.0430 \\
.0446 \\
.0444 \\
.0450 \\
.0454 \\
.0449 \\
.0470 \\
.0504\end{array}$ & $\begin{array}{c}-.0007 \\
-.0011 \\
-.0006 \\
-.0007 \\
-.0010 \\
-.0007 \\
-.0002 \\
0\end{array}$ \\
\hline 65.2 & $\begin{array}{l}110 \\
115 \\
120 \\
125 \\
130 \\
135 \\
140\end{array}$ & $\begin{array}{l}.081 \\
.107 \\
.141 \\
.189 \\
.247 \\
.331 \\
.413\end{array}$ & $\begin{array}{r}.0542 \\
.0545 \\
.0550 \\
.0548 \\
.0561 \\
.0558 \\
.0597\end{array}$ & $\begin{array}{l}-.0015 \\
+.0005 \\
-.0002 \\
+.0002 \\
+.0002 \\
+.0004 \\
+.0007\end{array}$ \\
\hline 76.2 & $\begin{array}{l}110 \\
115 \\
120\end{array}$ & $\begin{array}{l}.070 \\
.082 \\
.121\end{array}$ & $\begin{array}{r}.0624 \\
.0636 \\
.0644\end{array}$ & $\begin{array}{l}+.0011 \\
+.0006 \\
+.0010\end{array}$ \\
\hline
\end{tabular}




\begin{tabular}{lllll}
$\begin{array}{c}V_{\infty}^{*} \\
(m e t e r s / s e c)\end{array}$ & $\begin{array}{l}P_{i^{*}} \\
(\mathrm{~dB})\end{array}$ & $C_{D}$ & $R_{0}^{*} / \rho^{*} c^{*}$ & $X_{t}^{*} / \rho^{*} \mathrm{c}$ \\
\hline 76.2 & 125 & .160 & .0649 & .0012 \\
& 130 & .200 & .0690 & .0014 \\
& 135 & .281 & .0657 & .0013 \\
& 140 & .367 & .0671 & .0012 \\
\hline
\end{tabular}

Mode1 \#3 $\mathrm{d}^{*}=1.02 \mathrm{~mm} ; \tau^{*}=0.81 \mathrm{~mm} ; \mathrm{D}^{*}=19.05 \mathrm{~mm} ; \mathrm{L}^{*}=12.70 \mathrm{~mm}$ $\mathrm{f}_{\mathrm{res}}{ }^{*}=590 \mathrm{~Hz} ; \mathrm{T}_{\infty}^{*}=64^{\circ} \mathrm{F} ; \mathrm{P}_{\infty}^{*}=29.91^{\prime \prime} \mathrm{Hg} ; \mathrm{d}_{\mathrm{e}}^{*} / \mathrm{d}^{*}=1.866$

\begin{tabular}{|c|c|c|c|c|}
\hline 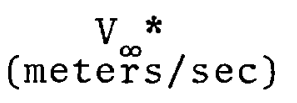 & $\mathrm{P}_{i}^{*}$ & $\mathrm{C}_{\mathrm{D}}$ & $\mathrm{R}_{\mathrm{O}} * / \rho * \mathrm{C} *$ & $X_{t} * / \rho^{*} c^{*}$ \\
\hline 0 & $\begin{array}{r}70 \\
80 \\
90 \\
100 \\
110 \\
115 \\
120 \\
125 \\
130 \\
135 \\
140 \\
145\end{array}$ & $\begin{array}{l}.107 \\
.192 \\
.329 \\
.516 \\
.635 \\
.635 \\
.642 \\
.635 \\
.650 \\
.665 \\
.672 \\
.688\end{array}$ & $\begin{array}{l}.0041 \\
.0040 \\
.0042 \\
.0047 \\
.0065 \\
.0085 \\
.0113 \\
.0156 \\
.0207 \\
.0273 \\
.0363 \\
.0474\end{array}$ & $\begin{array}{c}0 \\
0 \\
-.0001 \\
-.0005 \\
-.0023 \\
-.0034 \\
-.0043 \\
-.0047 \\
-.0045 \\
-.0045 \\
-.0035 \\
-.0037\end{array}$ \\
\hline 7.7 & $\begin{array}{l}110 \\
120 \\
130 \\
135 \\
140 \\
145\end{array}$ & $\begin{array}{l}.606 \\
.613 \\
.642 \\
.657 \\
.642 \\
.650\end{array}$ & $\begin{array}{r}.0067 \\
.0119 \\
.0209 \\
.0276 \\
.0379 \\
.0502\end{array}$ & $\begin{array}{l}-.0025 \\
-.0042 \\
-.0050 \\
-.0048 \\
-.0045 \\
-.0041\end{array}$ \\
\hline 13.0 & $\begin{array}{l}110 \\
120 \\
130 \\
135 \\
140 \\
145\end{array}$ & $\begin{array}{l}.534 \\
.599 \\
.620 \\
.635 \\
.620 \\
.635\end{array}$ & $\begin{array}{l}.0075 \\
.0120 \\
.0214 \\
.0284 \\
.0391 \\
.0513\end{array}$ & $\begin{array}{l}-.0033 \\
-.0047 \\
-.0059 \\
-.0057 \\
-.0057 \\
-.0049\end{array}$ \\
\hline
\end{tabular}




\begin{tabular}{|c|c|c|c|c|}
\hline $\begin{array}{c}V_{\infty}^{*} \\
(\text { meters/sec })\end{array}$ & $\begin{array}{l}\mathrm{P}_{\mathbf{i}^{*}}^{*} \\
(\mathrm{~dB})\end{array}$ & $\mathrm{C}_{\mathrm{D}}$ & $\mathrm{R}_{\mathrm{O}} * / \rho{ }^{*} \mathrm{c}$ & $x_{t} * / \rho^{*} c^{*}$ \\
\hline 20.8 & $\begin{array}{l}110 \\
120 \\
130 \\
135 \\
140 \\
145\end{array}$ & $\begin{array}{l}.326 \\
.424 \\
.528 \\
.559 \\
.579 \\
.606\end{array}$ & $\begin{array}{r}.0124 \\
.0170 \\
.0251 \\
.0320 \\
.0418 \\
.0536\end{array}$ & $\begin{array}{l}-.0052 \\
-.0068 \\
-.0072 \\
-.0077 \\
-.0069 \\
-.0062\end{array}$ \\
\hline 29.1 & $\begin{array}{l}110 \\
120 \\
130 \\
135 \\
140 \\
145\end{array}$ & $\begin{array}{l}.189 \\
.304 \\
.449 \\
.504 \\
.534 \\
.566\end{array}$ & $\begin{array}{l}.0219 \\
.0241 \\
.0298 \\
.0357 \\
.0453 \\
.0574\end{array}$ & $\begin{array}{l}-.0072 \\
-.0083 \\
-.0073 \\
-.0074 \\
-.0074 \\
-.0065\end{array}$ \\
\hline 41.0 & $\begin{array}{l}110 \\
120 \\
130 \\
135 \\
140 \\
145\end{array}$ & $\begin{array}{l}.124 \\
.215 \\
.349 \\
.434 \\
.493 \\
.534\end{array}$ & $\begin{array}{l}.0343 \\
.0349 \\
.0386 \\
.0417 \\
.0492 \\
.0608\end{array}$ & $\begin{array}{l}-.0078 \\
-.0088 \\
-.0084 \\
-.0073 \\
-.0074 \\
-.0069\end{array}$ \\
\hline 57.6 & $\begin{array}{l}110 \\
120 \\
130 \\
135 \\
140 \\
145\end{array}$ & $\begin{array}{l}.087 \\
.154 \\
.256 \\
.326 \\
.401 \\
.465\end{array}$ & $\begin{array}{l}.0499 \\
.0496 \\
.0532 \\
.0558 \\
.0607 \\
.0699\end{array}$ & $\begin{array}{l}-.0069 \\
-.0082 \\
-.0089 \\
-.0084 \\
-.0078 \\
-.0072\end{array}$ \\
\hline 70.9 & $\begin{array}{l}110 \\
120 \\
130 \\
135 \\
140 \\
145\end{array}$ & $\begin{array}{l}.073 \\
.121 \\
.210 \\
.274 \\
.341 \\
.429\end{array}$ & $\begin{array}{l}.0595 \\
.0636 \\
.0650 \\
.0666 \\
.0715 \\
.0759\end{array}$ & $\begin{array}{l}-.0064 \\
-.0080 \\
-.0086 \\
-.0084 \\
-.0074 \\
-.0069\end{array}$ \\
\hline 79.2 & $\begin{array}{l}110 \\
120 \\
130 \\
135 \\
140 \\
145\end{array}$ & $\begin{array}{l}.063 \\
.113 \\
.189 \\
.247 \\
.304 \\
.396\end{array}$ & $\begin{array}{l}.0685 \\
.0683 \\
.0723 \\
.0740 \\
.0803 \\
.0823\end{array}$ & $\begin{array}{l}-.0055 \\
-.0068 \\
-.0082 \\
-.0082 \\
-.0082 \\
-.0068\end{array}$ \\
\hline
\end{tabular}


Mode1 \#4 $\mathrm{d}^{*}=0.91 \mathrm{~mm} ; \tau^{*}=0.51 \mathrm{~mm} ; \mathrm{D}^{*}=19.05 \mathrm{~mm} ; \mathrm{I}^{*}=25.4 \mathrm{~mm}$ $\mathrm{f}_{\text {res }}{ }^{*}=416 \mathrm{~Hz} ; \mathrm{T}_{\infty}^{*}=71^{\circ} \mathrm{F} ; \mathrm{P}_{\infty}^{*}=29.92^{\prime \prime} \mathrm{Hz} ; \mathrm{d}^{*} \mathrm{e}^{*}=1.693$

\begin{tabular}{|c|c|c|c|c|}
\hline $\begin{array}{c}V_{\infty}^{*} \\
(\text { meters/sec) }\end{array}$ & $\begin{array}{l}P_{i}^{*} \\
(d B)\end{array}$ & $\mathrm{C}_{\mathrm{D}}$ & $\mathrm{R}_{\mathrm{O}} * / \rho^{*} \mathrm{C} *$ & $X_{t} * / \rho^{*} c^{*}$ \\
\hline 0 & $\begin{array}{r}70 \\
80 \\
90 \\
100 \\
110 \\
115 \\
120 \\
125 \\
130 \\
135\end{array}$ & $\begin{array}{l}.129 \\
.227 \\
.361 \\
.502 \\
.550 \\
.550 \\
.563 \\
.589 \\
.583 \\
.589\end{array}$ & $\begin{array}{l}.0034 \\
.0034 \\
.0036 \\
.0046 \\
.0071 \\
.0096 \\
.0129 \\
.0162 \\
.0229 \\
.0305\end{array}$ & $\begin{array}{c}0 \\
0 \\
-.0003 \\
-.0017 \\
-.0035 \\
-.0044 \\
-.0049 \\
-.0053 \\
-.0061 \\
-.0069\end{array}$ \\
\hline 8.5 & $\begin{array}{l}110 \\
115 \\
120 \\
125 \\
130 \\
135\end{array}$ & $\begin{array}{l}.535 \\
.544 \\
.568 \\
.582 \\
.588 \\
.589\end{array}$ & $\begin{array}{l}.0075 \\
.0098 \\
.0129 \\
.0170 \\
.0229 \\
.0304\end{array}$ & $\begin{array}{l}-.0037 \\
-.0044 \\
-.0049 \\
-.0053 \\
-.0061 \\
-.0070\end{array}$ \\
\hline 13.4 & $\begin{array}{l}110 \\
115 \\
120 \\
125 \\
130 \\
135\end{array}$ & $\begin{array}{l}.506 \\
.519 \\
.555 \\
.569 \\
.581 \\
.556\end{array}$ & $\begin{array}{l}.0077 \\
.0101 \\
.0131 \\
.0172 \\
.0230 \\
.0321\end{array}$ & $\begin{array}{l}-.0040 \\
-.0048 \\
-.0052 \\
-.0058 \\
-.0066 \\
-.0079\end{array}$ \\
\hline 21.0 & $\begin{array}{l}110 \\
115 \\
120 \\
125 \\
130 \\
135\end{array}$ & $\begin{array}{l}.301 \\
.351 \\
.441 \\
.473 \\
.506 \\
.519\end{array}$ & $\begin{array}{l}.0131 \\
.0150 \\
.0164 \\
.0206 \\
.0262 \\
.0342\end{array}$ & $\begin{array}{l}-.0065 \\
-.0070 \\
-.0068 \\
-.0074 \\
-.0083 \\
-.0094\end{array}$ \\
\hline 29.3 & $\begin{array}{l}110 \\
115 \\
120 \\
125 \\
130 \\
135\end{array}$ & $\begin{array}{l}.186 \\
.266 \\
.305 \\
.376 \\
.436 \\
.473\end{array}$ & $\begin{array}{l}.0221 \\
.0203 \\
.0240 \\
.0261 \\
.0306 \\
.0376\end{array}$ & $\begin{array}{l}-.0086 \\
-.0080 \\
-.0091 \\
-.0088 \\
-.0091 \\
-.0099\end{array}$ \\
\hline
\end{tabular}




\begin{tabular}{|c|c|c|c|c|}
\hline $\begin{array}{c}V_{\infty} * \\
(\text { meters/sec) }\end{array}$ & $\begin{array}{l}\mathrm{P}_{i^{*}}^{*} \\
(\overline{\mathrm{dB}})\end{array}$ & $\mathrm{C}_{\mathrm{D}}$ & $\mathrm{R}_{0} * / \rho^{*} \mathrm{c}^{*}$ & $X_{t} * / \rho^{*} c^{*}$ \\
\hline 41.5 & $\begin{array}{l}110 \\
115 \\
120 \\
125 \\
130 \\
135\end{array}$ & $\begin{array}{l}.129 \\
.170 \\
.216 \\
.275 \\
.354 \\
.422\end{array}$ & $\begin{array}{r}.0330 \\
.0329 \\
.0347 \\
.0361 \\
.0380 \\
.0424\end{array}$ & $\begin{array}{l}-.0089 \\
-.0093 \\
-.0104 \\
-.0103 \\
-.0101 \\
-.0100\end{array}$ \\
\hline 58.2 & $\begin{array}{l}110 \\
115 \\
120 \\
125 \\
130 \\
135\end{array}$ & $\begin{array}{l}.090 \\
.120 \\
.148 \\
.214 \\
.278 \\
.339\end{array}$ & $\begin{array}{r}.0476 \\
.0471 \\
.0516 \\
.0471 \\
.0489 \\
.0533\end{array}$ & $\begin{array}{l}-.0111 \\
-.0109 \\
-.0120 \\
-.0110 \\
-.0105 \\
-.0104\end{array}$ \\
\hline 70.1 & $\begin{array}{l}110 \\
115 \\
120 \\
125 \\
130 \\
135\end{array}$ & $\begin{array}{r}.077 \\
.097 \\
.129 \\
.174 \\
.221 \\
.295\end{array}$ & $\begin{array}{r}.0566 \\
.0595 \\
.0602 \\
.0588 \\
.0622 \\
.0616\end{array}$ & $\begin{array}{l}-.0099 \\
-.0092 \\
-.0088 \\
-.0091 \\
-.0098 \\
-.0090\end{array}$ \\
\hline
\end{tabular}

Mode1 \# 5

$\mathrm{d}^{*}=1.32 \mathrm{~mm} ; \tau^{*}=0.81 \mathrm{~mm} ; \mathrm{D}^{*}=31.75 \mathrm{~mm} ; \mathrm{L}^{*}=12.70 \mathrm{~mm}$ $\mathrm{f}_{\text {res }}^{*}=428 \mathrm{~Hz} ; \mathrm{T}_{\infty}^{*}=69^{\circ} \mathrm{F} ; \mathrm{P} *=30.2^{\prime \prime \mathrm{Hg}} ; \mathrm{d}_{\mathrm{e}}^{*} / \mathrm{d}^{*}=1.665$

\begin{tabular}{ccccc}
$\begin{array}{c}V_{\infty} * \\
\text { (meters/sec) }\end{array}$ & $\begin{array}{c}P_{i^{*}} \\
(\mathrm{~d} B)\end{array}$ & $\mathrm{C}_{\mathrm{D}}$ & $\mathrm{R}_{\mathrm{O}}{ }^{*} / \rho^{*} \mathrm{c} *$ & $\mathrm{X}_{\mathrm{t}}{ }^{*} / \rho^{*} \mathrm{C} *$ \\
\hline 0 & 70 & .114 & .0038 & \\
\hline 80 & .198 & .0039 & 0 \\
& 90 & .328 & .0042 & -.0001 \\
& 100 & .502 & .0047 & -.0010 \\
& 110 & .570 & .0067 & -.0035 \\
& 115 & .577 & .0087 & -.0048 \\
& 120 & .564 & .0121 & -.0063 \\
& 125 & .577 & .0163 & -.0070 \\
& 130 & .557 & .0233 & -.0076 \\
& 135 & .577 & .0306 & -.0077
\end{tabular}




\begin{tabular}{|c|c|c|c|c|}
\hline $\begin{array}{c}V_{\infty}{ }^{*} \\
(\operatorname{meters} / \mathrm{sec})\end{array}$ & $\begin{array}{l}P_{i}^{*} \\
(d B)\end{array}$ & $\mathrm{C}_{\mathrm{D}}$ & $\mathrm{R}_{0} * / \rho{ }^{*}{ }^{*}$ & $X_{t} / \rho * c *$ \\
\hline 7.9 & $\begin{array}{l}115 \\
120 \\
125 \\
130 \\
135\end{array}$ & $\begin{array}{l}.557 \\
.545 \\
.545 \\
.551 \\
.564\end{array}$ & $\begin{array}{r}.0090 \\
.0125 \\
.0172 \\
.0235 \\
.0312\end{array}$ & $\begin{array}{l}-.0050 \\
-.0065 \\
-.0075 \\
-.0080 \\
-.0084\end{array}$ \\
\hline 13.7 & $\begin{array}{l}115 \\
120 \\
125 \\
130 \\
135\end{array}$ & $\begin{array}{r}.474 \\
.474 \\
.497 \\
.514 \\
.526\end{array}$ & $\begin{array}{r}.0105 \\
.0142 \\
.0185 \\
.0247 \\
.0330\end{array}$ & $\begin{array}{l}-.0060 \\
-.0078 \\
-.0091 \\
-.0098 \\
-.0105\end{array}$ \\
\hline 21.1 & $\begin{array}{l}115 \\
120 \\
125 \\
130 \\
135\end{array}$ & $\begin{array}{l}.273 \\
.336 \\
.395 \\
.433 \\
.464\end{array}$ & $\begin{array}{l}.0188 \\
.0206 \\
.0240 \\
.0295 \\
.0374\end{array}$ & $\begin{array}{l}-.0095 \\
-.0098 \\
-.0099 \\
-.0111 \\
-.0120\end{array}$ \\
\hline 29.0 & $\begin{array}{l}115 \\
120 \\
125 \\
130 \\
135\end{array}$ & $\begin{array}{l}.185 \\
.243 \\
.313 \\
.373 \\
.418\end{array}$ & $\begin{array}{r}.0291 \\
.0293 \\
.0305 \\
.0346 \\
.0416\end{array}$ & $\begin{array}{l}-.0112 \\
-.0117 \\
-.0115 \\
-.0116 \\
-.0128\end{array}$ \\
\hline 41.2 & $\begin{array}{l}115 \\
120 \\
125 \\
130 \\
135\end{array}$ & $\begin{array}{l}.125 \\
.178 \\
.227 \\
.286 \\
.352\end{array}$ & $\begin{array}{l}.0447 \\
.0416 \\
.0433 \\
.0459 \\
.0500\end{array}$ & $\begin{array}{l}-.0113 \\
-.0112 \\
-.0126 \\
-.0132 \\
-.0135\end{array}$ \\
\hline 57.6 & $\begin{array}{l}115 \\
120 \\
125 \\
130 \\
135\end{array}$ & $\begin{array}{l}.090 \\
.119 \\
.161 \\
.214 \\
.276\end{array}$ & $\begin{array}{l}.0623 \\
.0628 \\
.0621 \\
.0620 \\
.0641\end{array}$ & $\begin{array}{l}-.0133 \\
-.0142 \\
-.0140 \\
-.0145 \\
-.0153\end{array}$ \\
\hline 70.1 & $\begin{array}{l}115 \\
120 \\
125 \\
130 \\
135\end{array}$ & $\begin{array}{r}.071 \\
.098 \\
.129 \\
.174 \\
.227\end{array}$ & $\begin{array}{r}.0797 \\
.0770 \\
.0770 \\
.0768 \\
.0784\end{array}$ & $\begin{array}{l}-.0152 \\
-.0147 \\
-.0150 \\
-.0154 \\
-.0165\end{array}$ \\
\hline
\end{tabular}




\begin{tabular}{|c|c|c|c|c|}
\hline $\begin{array}{c}\mathrm{V}_{\infty}{ }^{*} \\
(\text { meters/sec) }\end{array}$ & $\begin{array}{l}\mathrm{P}_{i} \\
(\mathrm{~d} \cdot \mathrm{B})\end{array}$ & $\mathrm{C}_{\mathrm{D}}$ & $\mathrm{R}_{0} * / \rho^{*} \mathrm{C}^{*}$ & $x_{t}{ }^{*} / \rho^{*} c^{*}$ \\
\hline 78.6 & $\begin{array}{l}115 \\
120 \\
125 \\
130 \\
135\end{array}$ & $\begin{array}{l}.066 \\
.086 \\
.116 \\
.148 \\
.207\end{array}$ & $\begin{array}{r}.0853 \\
.0871 \\
.0861 \\
.0902 \\
.0861\end{array}$ & $\begin{array}{l}-.0167 \\
-.0180 \\
-.0178 \\
-.0185 \\
-.0177\end{array}$ \\
\hline
\end{tabular}

Model \#6

$\mathrm{d}^{*}=1.32 \mathrm{~mm} ; \tau *=0.81 \mathrm{~mm} ; \mathrm{D}^{*}=19.05 \mathrm{~mm} ; \mathrm{L}^{*}=25.40 \mathrm{~mm}$ $\mathrm{f}^{*}=493 \mathrm{~Hz} ; \mathrm{T}_{\infty}^{*}=64^{\circ} \mathrm{F} ; \mathrm{P}_{\infty}^{*}=29.9^{\prime \prime} \mathrm{Hg} ; \mathrm{d}_{\mathrm{e}}^{*} / \mathrm{d}^{*}=1.713$

\begin{tabular}{|c|c|c|c|c|}
\hline $\begin{array}{c}\mathrm{V}_{\infty}{ }^{*} \\
(\text { meters/sec) }\end{array}$ & $\begin{array}{l}P_{i}^{*} \\
(\mathrm{~dB})\end{array}$ & $\mathrm{C}_{\mathrm{D}}$ & $\mathrm{R}_{\mathrm{o}} * / \rho^{*} \mathrm{c}^{*}$ & $X_{t} * / \rho^{*} c^{*}$ \\
\hline 0 & $\begin{array}{r}70 \\
80 \\
90 \\
100 \\
110 \\
115 \\
120 \\
125 \\
130 \\
135 \\
140\end{array}$ & $\begin{array}{l}.087 \\
.153 \\
.262 \\
.415 \\
.535 \\
.554 \\
.554 \\
.548 \\
.548 \\
.567 \\
.573\end{array}$ & $\begin{array}{l}.0051 \\
.0052 \\
.0059 \\
.0060 \\
.0077 \\
.0096 \\
.0127 \\
.0175 \\
.0241 \\
.0318 \\
.0425\end{array}$ & $\begin{array}{c}0 \\
0 \\
-.0001 \\
-.0006 \\
-.0031 \\
-.0047 \\
-.0064 \\
-.0079 \\
-.0088 \\
-.0087 \\
-.0093\end{array}$ \\
\hline 7.9 & $\begin{array}{l}115 \\
120 \\
125 \\
130 \\
135 \\
140\end{array}$ & $\begin{array}{l}.535 \\
.541 \\
.535 \\
.541 \\
.548 \\
.560\end{array}$ & $\begin{array}{r}.0098 \\
.0131 \\
.0179 \\
.0242 \\
.0328 \\
.0433\end{array}$ & $\begin{array}{l}-.0051 \\
-.0064 \\
-.0080 \\
-.0092 \\
-.0096 \\
-.0104\end{array}$ \\
\hline 14.0 & $\begin{array}{l}115 \\
120 \\
125\end{array}$ & $\begin{array}{l}.435 \\
.472 \\
.488\end{array}$ & $\begin{array}{r}.0118 \\
.0147 \\
.0192\end{array}$ & $\begin{array}{l}-.0068 \\
-.0081 \\
-.0098\end{array}$ \\
\hline
\end{tabular}




\begin{tabular}{|c|c|c|c|c|}
\hline $\begin{array}{c}V_{\infty}{ }^{*} \\
(\text { meters/sec })\end{array}$ & $\begin{array}{l}P_{i *}^{*} \\
(\mathrm{~dB})\end{array}$ & $\mathrm{C}_{\mathrm{D}}$ & $R_{0} * / \rho * c *$ & $X_{t}^{*} / \rho^{*} c^{*}$ \\
\hline & $\begin{array}{l}130 \\
135 \\
140\end{array}$ & $\begin{array}{l}.494 \\
.511 \\
.529\end{array}$ & $\begin{array}{r}.0260 \\
.0348 \\
.0456\end{array}$ & $\begin{array}{l}-.0114 \\
-.0115 \\
-.0120\end{array}$ \\
\hline 21.3 & $\begin{array}{l}115 \\
120 \\
125 \\
130 \\
135 \\
140\end{array}$ & $\begin{array}{l}.284 \\
.326 \\
.388 \\
.425 \\
.456 \\
.499\end{array}$ & $\begin{array}{l}.0183 \\
.0216 \\
.0249 \\
.0308 \\
.0391 \\
.0484\end{array}$ & $\begin{array}{l}-.0098 \\
-.0109 \\
-.0108 \\
-.0119 \\
-.0125 \\
-.0123\end{array}$ \\
\hline 29.3 & $\begin{array}{l}115 \\
120 \\
125 \\
130 \\
135 \\
140\end{array}$ & $\begin{array}{l}.192 \\
.250 \\
.308 \\
.366 \\
.415 \\
.461\end{array}$ & $\begin{array}{r}.0285 \\
.0291 \\
.0319 \\
.0364 \\
.0432 \\
.0525\end{array}$ & $\begin{array}{l}-.0117 \\
-.0121 \\
-.0122 \\
-.0119 \\
-.0126 \\
-.0131\end{array}$ \\
\hline 41.1 & $\begin{array}{l}115 \\
120 \\
125 \\
130 \\
135 \\
140\end{array}$ & $\begin{array}{l}.136 \\
.173 \\
.245 \\
.294 \\
.362 \\
.420\end{array}$ & $\begin{array}{r}.0419 \\
.0437 \\
.0412 \\
.0460 \\
.0502 \\
.0579\end{array}$ & $\begin{array}{l}-.0118 \\
-.0128 \\
-.0123 \\
-.0127 \\
-.0123 \\
-.0130\end{array}$ \\
\hline 57.3 & $\begin{array}{l}115 \\
120 \\
125 \\
130 \\
135 \\
140\end{array}$ & $\begin{array}{l}.090 \\
.125 \\
.163 \\
.213 \\
.271 \\
.350\end{array}$ & $\begin{array}{r}.0642 \\
.0614 \\
.0628 \\
.0640 \\
.0673 \\
.0700\end{array}$ & $\begin{array}{r}-.0148 \\
-.0137 \\
-.0143 \\
-.0154 \\
-.0149 \\
-.0141\end{array}$ \\
\hline 70.4 & $\begin{array}{l}115 \\
120 \\
125 \\
130 \\
135 \\
140\end{array}$ & $\begin{array}{l}.074 \\
.101 \\
.138 \\
.173 \\
.234 \\
.298\end{array}$ & $\begin{array}{r}.0793 \\
.0775 \\
.0757 \\
.0801 \\
.0790 \\
.0878\end{array}$ & $\begin{array}{r}-.0112 \\
-.0107 \\
-.0110 \\
-.0124 \\
-.0132 \\
-.0133\end{array}$ \\
\hline 79.2 & $\begin{array}{l}115 \\
120 \\
125 \\
130 \\
135 \\
140\end{array}$ & $\begin{array}{l}.064 \\
.083 \\
.116 \\
.154 \\
.203 \\
.204\end{array}$ & $\begin{array}{r}.0929 \\
.0951 \\
.0907 \\
.0906 \\
.0915 \\
.0873\end{array}$ & $\begin{array}{l}-.0045 \\
-.0048 \\
-.0054 \\
-.0072 \\
-.0092 \\
-.0098\end{array}$ \\
\hline
\end{tabular}


Mode1 \# 7

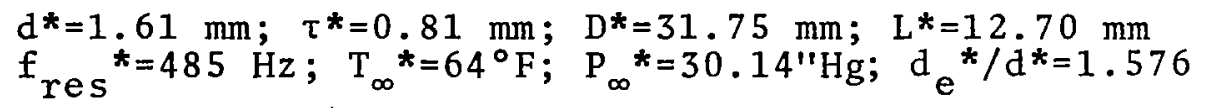

\begin{tabular}{|c|c|c|c|c|}
\hline $\begin{array}{c}\mathrm{V}_{\infty}{ }^{*} \\
\text { (meters/sec) }\end{array}$ & $\begin{array}{l}P_{i^{*}} \\
\left(d^{\prime} B\right)\end{array}$ & $\mathrm{C}_{\mathrm{D}}$ & $\mathrm{R}_{\mathrm{O}}^{*} / \rho * \mathrm{c} *$ & $\mathrm{X}_{\mathrm{t}}{ }^{*} / \mathrm{o}^{*} \mathrm{c}^{*}$ \\
\hline 0 & $\begin{array}{r}70 \\
80 \\
90 \\
100 \\
110 \\
115 \\
120 \\
125 \\
130 \\
135\end{array}$ & $\begin{array}{l}.100 \\
.173 \\
.297 \\
.460 \\
.541 \\
.560 \\
.553 \\
.541 \\
.522 \\
.516\end{array}$ & $\begin{array}{l}.0043 \\
.0045 \\
.0046 \\
.0053 \\
.0079 \\
.0098 \\
.0131 \\
.0181 \\
.0254 \\
.0352\end{array}$ & $\begin{array}{c}0 \\
0 \\
-.0001 \\
-.0005 \\
-.0018 \\
-.0033 \\
-.0046 \\
-.0056 \\
-.0066 \\
-.0035\end{array}$ \\
\hline 7.9 & $\begin{array}{l}115 \\
120 \\
125 \\
130 \\
135\end{array}$ & $\begin{array}{l}.535 \\
.528 \\
.522 \\
.510 \\
.516\end{array}$ & $\begin{array}{l}.0102 \\
.0138 \\
.0188 \\
.0261 \\
.0351\end{array}$ & $\begin{array}{l}-.0036 \\
-.0047 \\
-.0056 \\
-.0060 \\
-.0045\end{array}$ \\
\hline 13.9 & $\begin{array}{l}115 \\
120 \\
125 \\
130 \\
135\end{array}$ & $\begin{array}{l}.445 \\
.482 \\
.471 \\
.471 \\
.487\end{array}$ & $\begin{array}{l}.0120 \\
.0148 \\
.0206 \\
.0278 \\
.0368\end{array}$ & $\begin{array}{l}-.0050 \\
-.0060 \\
-.0072 \\
-.0084 \\
-.0071\end{array}$ \\
\hline 21.5 & $\begin{array}{l}115 \\
120 \\
125 \\
130 \\
135\end{array}$ & $\begin{array}{l}.239 \\
.297 \\
.361 \\
.392 \\
.434\end{array}$ & $\begin{array}{l}.0218 \\
.0235 \\
.0264 \\
.0331 \\
.0401\end{array}$ & $\begin{array}{l}-.0105 \\
-.0108 \\
-.0104 \\
-.0111 \\
-.0125\end{array}$ \\
\hline 29.3 & $\begin{array}{l}115 \\
120 \\
125 \\
130 \\
135\end{array}$ & $\begin{array}{l}.167 \\
.220 \\
.274 \\
.326 \\
.387\end{array}$ & $\begin{array}{l}.0317 \\
.0320 \\
.0348 \\
.0397 \\
.0449\end{array}$ & $\begin{array}{l}-.0138 \\
-.0140 \\
-.0138 \\
-.0137 \\
-.0143\end{array}$ \\
\hline 41.4 & $\begin{array}{l}115 \\
120 \\
125 \\
130 \\
135\end{array}$ & $\begin{array}{l}.110 \\
.149 \\
.194 \\
.244 \\
.304\end{array}$ & $\begin{array}{l}.0494 \\
.0488 \\
.0501 \\
.0533 \\
.0576\end{array}$ & $\begin{array}{l}-.0171 \\
-.0170 \\
-.0170 \\
-.0171 \\
-.0169\end{array}$ \\
\hline
\end{tabular}




\begin{tabular}{|c|c|c|c|c|}
\hline $\begin{array}{c}V_{\infty}{ }^{*} \\
(\operatorname{meters} / \mathrm{sec})\end{array}$ & $P_{\left.j_{B}^{*}\right)}^{*}$ & $\mathrm{C}_{\mathrm{D}}$ & $\mathrm{R}_{\mathrm{O}} * / \rho * \mathrm{c} *$ & $X_{t} * / \rho^{*} c^{*}$ \\
\hline 58.2 & $\begin{array}{l}115 \\
120 \\
125 \\
130 \\
135\end{array}$ & $\begin{array}{l}.081 \\
.109 \\
.139 \\
.179 \\
.231\end{array}$ & $\begin{array}{l}.0682 \\
.0673 \\
.0705 \\
.0730 \\
.0758\end{array}$ & $\begin{array}{l}-.0211 \\
-.0230 \\
-.0220 \\
-.0217 \\
-.0229\end{array}$ \\
\hline 70.9 & $\begin{array}{l}115 \\
120 \\
125 \\
130 \\
135\end{array}$ & $\begin{array}{l}.065 \\
.086 \\
.114 \\
.147 \\
.185\end{array}$ & $\begin{array}{r}.0857 \\
.0868 \\
.0867 \\
.0894 \\
.0948\end{array}$ & $\begin{array}{l}-.0234 \\
-.0231 \\
-.0236 \\
-.0255 \\
-.0268\end{array}$ \\
\hline 79.7 & $\begin{array}{l}115 \\
120 \\
125 \\
130 \\
135\end{array}$ & $\begin{array}{l}.058 \\
.076 \\
.098 \\
.131 \\
.167\end{array}$ & $\begin{array}{r}.0968 \\
.0981 \\
.1011 \\
.1009 \\
.1056\end{array}$ & $\begin{array}{l}-.0236 \\
-.0232 \\
-.0251 \\
-.0265 \\
-.0281\end{array}$ \\
\hline
\end{tabular}

Mode1 \#8

$\mathrm{d}^{*}=1.78 \mathrm{~mm} ; \tau^{*}=0.51 \mathrm{~mm} ; \mathrm{D}^{*}=31.75 \mathrm{~mm} ; \mathrm{L}^{*}=25.4 \mathrm{~mm}$ $\mathrm{f}_{\text {res }}^{*}=385 \mathrm{~Hz} ; \mathrm{T}_{\infty}^{*}=68^{\circ} \mathrm{F} ; \mathrm{P}_{\infty}^{*}=30.15^{\prime \prime} \mathrm{Hg} ; \mathrm{d}_{\mathrm{e}}^{*} / \mathrm{d}^{*}=1.382$

\begin{tabular}{|c|c|c|c|c|}
\hline $\begin{array}{c}\mathrm{V}_{\infty}{ }^{*} \\
(\text { meters/sec })\end{array}$ & $\begin{array}{l}\mathrm{P}_{\dot{i}} * \\
(\dot{d} B)\end{array}$ & $\mathrm{C}_{\mathrm{D}}$ & $R_{0} * / \rho * c *$ & $x_{t} * / \rho * c^{*}$ \\
\hline 0 & $\begin{array}{r}70 \\
80 \\
90 \\
100 \\
110 \\
115 \\
120 \\
125 \\
130 \\
135\end{array}$ & $\begin{array}{l}.162 \\
.275 \\
.426 \\
.530 \\
.542 \\
.536 \\
.531 \\
.524 \\
.519 \\
.518\end{array}$ & $\begin{array}{r}.0027 \\
.0028 \\
.0032 \\
.0042 \\
.0069 \\
.0094 \\
.0133 \\
.0184 \\
.0257 \\
.0345\end{array}$ & $\begin{array}{c}0 \\
0 \\
-.0004 \\
-.0019 \\
-.0041 \\
-.0053 \\
-.0061 \\
-.0065 \\
-.0070 \\
-.0068\end{array}$ \\
\hline
\end{tabular}




\begin{tabular}{|c|c|c|c|c|}
\hline $\begin{array}{c}V_{\infty}^{*} \\
(\text { meters/sec) }\end{array}$ & $\begin{array}{l}P_{i} * \\
(\mathrm{~dB})\end{array}$ & $\mathrm{C}_{\mathrm{D}}$ & $\mathrm{R}_{\mathrm{O}} * / \rho^{*} \mathrm{c}^{*}$ & $x_{t} * / \rho c^{*}$ \\
\hline 7.0 & $\begin{array}{l}110 \\
115 \\
120 \\
125 \\
130 \\
135\end{array}$ & $\begin{array}{l}.525 \\
.524 \\
.519 \\
.518 \\
.513 \\
.512\end{array}$ & $\begin{array}{l}.0071 \\
.0097 \\
.0138 \\
.0188 \\
.0261 \\
.0349\end{array}$ & $\begin{array}{l}-.0043 \\
-.0052 \\
-.0058 \\
-.0060 \\
-.0066 \\
-.0067\end{array}$ \\
\hline 13.1 & $\begin{array}{l}110 \\
115 \\
120 \\
125 \\
130 \\
135\end{array}$ & $\begin{array}{l}.417 \\
.446 \\
.473 \\
.500 \\
.501 \\
.512\end{array}$ & $\begin{array}{r}.0090 \\
.0113 \\
.0149 \\
.0192 \\
.0265 \\
.0348\end{array}$ & $\begin{array}{l}-.0054 \\
-.0062 \\
-.0069 \\
-.0070 \\
-.0076 \\
-.0072\end{array}$ \\
\hline 21.0 & $\begin{array}{l}110 \\
115 \\
120 \\
125 \\
130 \\
135\end{array}$ & $\begin{array}{r}.221 \\
.239 \\
.339 \\
.397 \\
.437 \\
.467\end{array}$ & $\begin{array}{r}.0179 \\
.0220 \\
.0214 \\
.0244 \\
.0305 \\
.0380\end{array}$ & $\begin{array}{l}-.0084 \\
-.0097 \\
-.0083 \\
-.0081 \\
-.0087 \\
-.0088\end{array}$ \\
\hline 29.0 & $\begin{array}{l}110 \\
115 \\
120 \\
125 \\
130 \\
135\end{array}$ & $\begin{array}{l}.140 \\
.186 \\
.240 \\
.311 \\
.376 \\
.420\end{array}$ & $\begin{array}{l}.0294 \\
.0291 \\
.0307 \\
.0314 \\
.0356 \\
.0422\end{array}$ & $\begin{array}{l}-.0108 \\
-.0104 \\
-.0103 \\
-.0094 \\
-.0093 \\
-.0094\end{array}$ \\
\hline 41.1 & $\begin{array}{l}110 \\
115 \\
120 \\
125 \\
130 \\
135\end{array}$ & $\begin{array}{l}.101 \\
.127 \\
.172 \\
.215 \\
.299 \\
.349\end{array}$ & $\begin{array}{r}.0415 \\
.0436 \\
.0436 \\
.0459 \\
.0451 \\
.0509\end{array}$ & $\begin{array}{l}-.0121 \\
-.0122 \\
-.0121 \\
-.0119 \\
-.0107 \\
-.0103\end{array}$ \\
\hline 57.9 & $\begin{array}{l}110 \\
115 \\
120 \\
125 \\
130 \\
135\end{array}$ & $\begin{array}{l}.068 \\
.091 \\
.119 \\
.158 \\
.216 \\
.281\end{array}$ & $\begin{array}{l}.0631 \\
.0618 \\
.0640 \\
.0637 \\
.0628 \\
.0637\end{array}$ & $\begin{array}{l}-.0140 \\
-.0131 \\
-.0134 \\
-.0128 \\
-.0119 \\
-.0110\end{array}$ \\
\hline
\end{tabular}




\begin{tabular}{|c|c|c|c|c|}
\hline $\begin{array}{c}V_{\infty}^{*} \\
(\text { meters/sec) }\end{array}$ & $\mathrm{P}_{j^{*}}^{*}$ & $\mathrm{C}_{\mathrm{D}}$ & $R_{0} * / \rho * C *$ & $X_{t} * / \rho * c *$ \\
\hline 70.7 & $\begin{array}{l}110 \\
115 \\
120 \\
125 \\
130 \\
135\end{array}$ & $\begin{array}{l}.059 \\
.072 \\
.098 \\
.121 \\
.172 \\
.225\end{array}$ & $\begin{array}{r}.0730 \\
.0796 \\
.0784 \\
.0832 \\
.0794 \\
.0795\end{array}$ & $\begin{array}{l}-.0135 \\
-.0126 \\
-.0132 \\
-.0136 \\
-.0129 \\
-.0123\end{array}$ \\
\hline 79.2 & $\begin{array}{l}110 \\
115 \\
120 \\
125 \\
130 \\
135\end{array}$ & $\begin{array}{l}.051 \\
.062 \\
.086 \\
.117 \\
.153 \\
.203\end{array}$ & $\begin{array}{l}.0849 \\
.0910 \\
.0890 \\
.0860 \\
.0891 \\
.0883\end{array}$ & $\begin{array}{l}-.0147 \\
-.0159 \\
-.0152 \\
-.0147 \\
-.0142 \\
-.0135\end{array}$ \\
\hline
\end{tabular}

Mode1 \#9

$\mathrm{d}^{*}=1.78 \mathrm{~mm} ; \tau^{*}=0.51 \mathrm{~mm} ; \mathrm{D}^{*}=19.05 \mathrm{~mm} ; \mathrm{L}^{*}=25.4 \mathrm{~mm}$

$\mathrm{f}_{\text {res }}{ }^{*}=653 \mathrm{~Hz} ; \mathrm{T}_{\infty}{ }^{*}=68^{\circ} \mathrm{F} ; \mathrm{P}_{\infty}{ }^{*}=30.15^{\prime \prime} \mathrm{Hg} ; \mathrm{d}_{\mathrm{e}}{ }^{*} / \mathrm{d}^{*}=1.307$

\begin{tabular}{|c|c|c|c|}
\hline $\begin{array}{c}V_{\infty}{ }^{*} \\
(\text { meters } / \text { sec })\end{array}$ & $\mathrm{P}_{\mathrm{i}_{\mathrm{d}}^{*}}^{*}$ & $\mathrm{C}_{\mathrm{D}}$ & $\mathrm{R}_{\mathrm{O}} * / \rho^{*} \mathrm{C} *$ \\
\hline
\end{tabular}

0

70
80
90
100
110
115
120
125
130
135
140

.127

.223

.379

.548

.587

.587

.582

.561

.549

.548

.543

.0035
.0035
.0037
.0045
.0067
.0088
.0121
.0170
.0243
.0329
.0457

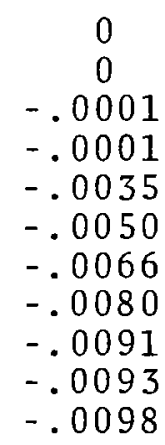




\begin{tabular}{|c|c|c|c|c|}
\hline $\begin{array}{c}\mathrm{V}_{\infty} * \\
\text { (meters/sec) }\end{array}$ & $\mathrm{P}_{\dot{\mathrm{I}}}^{*}$ & $\mathrm{C}_{\mathrm{D}}$ & $\mathrm{R}_{\mathrm{O}} * / \rho^{*} \mathrm{c} *$ & $X_{t} * / \rho^{*} c^{*}$ \\
\hline 7.3 & $\begin{array}{l}115 \\
120 \\
125 \\
130 \\
135 \\
140\end{array}$ & $\begin{array}{r}.569 \\
.562 \\
.548 \\
.543 \\
.544 \\
.543\end{array}$ & $\begin{array}{l}.0091 \\
.0125 \\
.0193 \\
.0247 \\
.0333 \\
.0457\end{array}$ & $\begin{array}{l}-.0055 \\
-.0069 \\
-.0089 \\
-.0089 \\
-.0094 \\
-.0097\end{array}$ \\
\hline 13.4 & $\begin{array}{l}115 \\
120 \\
125 \\
130 \\
135 \\
140\end{array}$ & $\begin{array}{l}.501 \\
.537 \\
.531 \\
.531 \\
.549 \\
.543\end{array}$ & $\begin{array}{r}.0101 \\
.0129 \\
.0181 \\
.0250 \\
.0332 \\
.0455\end{array}$ & $\begin{array}{l}-.0065 \\
-.0075 \\
-.0087 \\
-.0099 \\
-.0098 \\
-.0102\end{array}$ \\
\hline 21.3 & $\begin{array}{l}115 \\
120 \\
125 \\
130 \\
135 \\
140\end{array}$ & $\begin{array}{l}.363 \\
.412 \\
.446 \\
.478 \\
.457 \\
.531\end{array}$ & $\begin{array}{l}.0143 \\
.0171 \\
.0216 \\
.0276 \\
.0395 \\
.0468\end{array}$ & $\begin{array}{l}-.0084 \\
-.0093 \\
-.0103 \\
-.0112 \\
-.0131 \\
-.0120\end{array}$ \\
\hline 28.7 & $\begin{array}{l}115 \\
120 \\
125 \\
130 \\
135 \\
140\end{array}$ & $\begin{array}{l}.197 \\
.266 \\
.347 \\
.407 \\
.478 \\
.513\end{array}$ & $\begin{array}{l}.0273 \\
.0271 \\
.0282 \\
.0327 \\
.0376 \\
.0475\end{array}$ & $\begin{array}{l}-.0135 \\
-.0131 \\
-.0124 \\
-.0126 \\
-.0120 \\
-.0137\end{array}$ \\
\hline 41.1 & $\begin{array}{l}115 \\
120 \\
125 \\
130 \\
135 \\
140\end{array}$ & $\begin{array}{l}.141 \\
.188 \\
.254 \\
.316 \\
.393 \\
.457\end{array}$ & $\begin{array}{r}.0392 \\
.0393 \\
.0388 \\
.0422 \\
.0454 \\
.0528\end{array}$ & $\begin{array}{r}-.0167 \\
-.0164 \\
-.0162 \\
-.0165 \\
-.0165 \\
-.0172\end{array}$ \\
\hline 58.2 & $\begin{array}{l}115 \\
120 \\
125 \\
130 \\
135 \\
140\end{array}$ & $\begin{array}{l}.097 \\
.132 \\
.172 \\
.226 \\
.305 \\
.376\end{array}$ & $\begin{array}{r}.0576 \\
.0563 \\
.0577 \\
.0586 \\
.0581 \\
.0632\end{array}$ & $\begin{array}{l}-.0236 \\
-.0231 \\
-.0233 \\
-.0232 \\
-.0225 \\
-.0236\end{array}$ \\
\hline
\end{tabular}




\begin{tabular}{|c|c|c|c|c|}
\hline $\begin{array}{c}V_{\infty}{ }^{*} \\
(\text { meters/sec) }\end{array}$ & $\begin{array}{l}\mathrm{P}_{i^{*}}^{*} \\
(\mathrm{~d} B)\end{array}$ & ${ }^{C}{ }_{D}$ & $\mathrm{R}_{\mathrm{o}} * / \rho * \mathrm{c} *$ & $X_{t} * / \rho * c *$ \\
\hline 71.3 & $\begin{array}{l}115 \\
120 \\
125 \\
130 \\
135 \\
140\end{array}$ & $\begin{array}{l}.077 \\
.112 \\
.135 \\
.172 \\
.248 \\
.320\end{array}$ & $\begin{array}{l}.0718 \\
.0656 \\
.0727 \\
.0764 \\
.0708 \\
.0737\end{array}$ & $\begin{array}{l}-.0314 \\
-.0285 \\
-.0315 \\
-.0324 \\
-.0292 \\
-.0292\end{array}$ \\
\hline 79.2 & $\begin{array}{l}115 \\
120 \\
125 \\
130 \\
135 \\
140\end{array}$ & $\begin{array}{l}.067 \\
.091 \\
.126 \\
.172 \\
.214 \\
.288\end{array}$ & $\begin{array}{l}.0832 \\
.0815 \\
.0784 \\
.0771 \\
.0829 \\
.0823\end{array}$ & $\begin{array}{l}-.0343 \\
-.0331 \\
-.0326 \\
-.0308 \\
-.0323 \\
-.0311\end{array}$ \\
\hline
\end{tabular}

Model \#10

$\mathrm{d}^{*}=1.85 \mathrm{~mm} ; \tau^{*}=0.81 \mathrm{~mm} ; \mathrm{D}^{*}=31.75 \mathrm{~mm} ; \mathrm{L}^{*}=25.4 \mathrm{~mm}$ $\mathrm{f}_{\text {res }}^{*}=391 \mathrm{~Hz} ; \mathrm{T}_{\infty}^{*}=64^{\circ} \mathrm{F} ; \mathrm{P}_{\infty}^{*}=30^{\prime \prime} \mathrm{Hg} ; \mathrm{d}^{*} / \mathrm{d}^{*}=1.389$

\begin{tabular}{|c|c|c|c|c|}
\hline $\begin{array}{c}V_{\infty}^{*} \\
(\text { meters } / \text { sec })\end{array}$ & $\begin{array}{l}\mathrm{P}_{i}^{*} \\
(\mathrm{~d} B)\end{array}$ & $\mathrm{C}_{\mathrm{D}}$ & $\mathrm{R}_{\mathrm{o}}{ }^{*} / \rho^{*} \mathrm{C}^{*}$ & $x_{t} * / \rho^{*} c^{*}$ \\
\hline 0 & $\begin{array}{r}70 \\
80 \\
90 \\
100 \\
110 \\
115 \\
120 \\
125 \\
130 \\
135\end{array}$ & $\begin{array}{l}.142 \\
.250 \\
.415 \\
.580 \\
.607 \\
.607 \\
.580 \\
.560 \\
.545 \\
.541\end{array}$ & $\begin{array}{l}.0031 \\
.0031 \\
.0033 \\
.0041 \\
.0061 \\
.0080 \\
.0114 \\
.0163 \\
.0237 \\
.0328\end{array}$ & $\begin{array}{c}0 \\
0 \\
-.0002 \\
-.0012 \\
-.0038 \\
-.0054 \\
-.0078 \\
-.0089 \\
-.0099 \\
-.0098\end{array}$ \\
\hline
\end{tabular}




\begin{tabular}{|c|c|c|c|c|}
\hline $\begin{array}{c}V_{\infty} * \\
(\text { meters/sec })\end{array}$ & $\mathrm{P}_{\dot{i}^{*}}$ & $\mathrm{C}_{\mathrm{D}}$ & $R_{0}^{*} / \rho * c^{*}$ & $x_{t} * / \rho * c *$ \\
\hline 8.0 & $\begin{array}{l}115 \\
120 \\
125 \\
130 \\
135\end{array}$ & $\begin{array}{l}.547 \\
.554 \\
.535 \\
.523 \\
.529\end{array}$ & $\begin{array}{l}.0088 \\
.0120 \\
.0170 \\
.0244 \\
.0334\end{array}$ & $\begin{array}{l}-.0061 \\
-.0075 \\
-.0094 \\
-.0105 \\
-.0106\end{array}$ \\
\hline 13.9 & $\begin{array}{l}115 \\
120 \\
125 \\
130 \\
135\end{array}$ & $\begin{array}{l}.455 \\
.461 \\
.488 \\
.488 \\
.511\end{array}$ & $\begin{array}{r}.0109 \\
.0144 \\
.0185 \\
.0259 \\
.0343\end{array}$ & $\begin{array}{l}-.0068 \\
-.0089 \\
-.0107 \\
-.0118 \\
-.0118\end{array}$ \\
\hline 21.0 & $\begin{array}{l}115 \\
120 \\
125 \\
130 \\
135\end{array}$ & $\begin{array}{l}.268 \\
.322 \\
.388 \\
.425 \\
.455\end{array}$ & $\begin{array}{r}.0188 \\
.0214 \\
.0245 \\
.0302 \\
.0385\end{array}$ & $\begin{array}{l}-.0111 \\
-.0114 \\
-.0111 \\
-.0125 \\
-.0130\end{array}$ \\
\hline 29.2 & $\begin{array}{l}115 \\
120 \\
125 \\
130\end{array}$ & $\begin{array}{l}.179 \\
.236 \\
.284 \\
.410\end{array}$ & $\begin{array}{l}.0294 \\
.0299 \\
.0338 \\
.0363\end{array}$ & $\begin{array}{l}-.0142 \\
-.0141 \\
-.0143 \\
-.0140\end{array}$ \\
\hline 41.2 & $\begin{array}{l}115 \\
120 \\
125 \\
130 \\
135\end{array}$ & $\begin{array}{l}.125 \\
.165 \\
.218 \\
.268 \\
.341\end{array}$ & $\begin{array}{l}.0437 \\
.0441 \\
.0448 \\
.0491 \\
.0522\end{array}$ & $\begin{array}{l}-.0164 \\
-.0170 \\
-.0166 \\
-.0165 \\
-.0148\end{array}$ \\
\hline 58.1 & $\begin{array}{l}115 \\
120 \\
125 \\
130 \\
135\end{array}$ & $\begin{array}{l}.089 \\
.118 \\
.153 \\
.208 \\
.262\end{array}$ & $\begin{array}{l}.0635 \\
.0633 \\
.0656 \\
.0644 \\
.0690\end{array}$ & $\begin{array}{l}-.0180 \\
-.0185 \\
-.0189 \\
-.0174 \\
-.0155\end{array}$ \\
\hline 70.1 & $\begin{array}{l}115 \\
120 \\
125 \\
130 \\
135\end{array}$ & $\begin{array}{l}.074 \\
.102 \\
.134 \\
.169 \\
.218\end{array}$ & $\begin{array}{r}.0778 \\
.0751 \\
.0757 \\
.0803 \\
.0837\end{array}$ & $\begin{array}{l}-.0152 \\
-.0153 \\
-.0168 \\
-.0171 \\
-.0148\end{array}$ \\
\hline 79.4 & $\begin{array}{l}115 \\
120 \\
125 \\
130 \\
135\end{array}$ & $\begin{array}{l}.067 \\
.090 \\
.117 \\
.147 \\
.188\end{array}$ & $\begin{array}{r}.0857 \\
.0849 \\
.0869 \\
.0923 \\
.0974\end{array}$ & $\begin{array}{l}-.0198 \\
-.0189 \\
-.0191 \\
-.0193 \\
-.0158\end{array}$ \\
\hline
\end{tabular}


Mode1 \#11

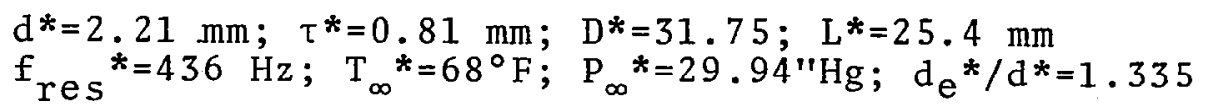

\begin{tabular}{|c|c|c|c|c|}
\hline $\begin{array}{c}V_{\infty}^{*} \\
(\text { meters/sec) }\end{array}$ & $\begin{array}{l}P_{j} \\
\left(d_{B}\right)\end{array}$ & $C_{D}$ & $\mathrm{R}_{\mathrm{O}}^{*} / \rho^{*} \mathrm{C} *$ & $x_{t} * / \rho * c *$ \\
\hline 0 & $\begin{array}{r}70 \\
80 \\
90 \\
100 \\
110 \\
115 \\
120 \\
125 \\
130 \\
135\end{array}$ & $\begin{array}{l}.136 \\
.233 \\
.378 \\
.541 \\
.579 \\
.607 \\
.580 \\
.560 \\
.535 \\
.535\end{array}$ & $\begin{array}{l}.0032 \\
.0034 \\
.0037 \\
.0045 \\
.0066 \\
.0078 \\
.0108 \\
.0153 \\
.0225 \\
.0320\end{array}$ & $\begin{array}{c}0 \\
0 \\
-.0001 \\
-.0007 \\
-.0038 \\
-.0057 \\
-.0081 \\
-.0107 \\
-.0132 \\
-.0136\end{array}$ \\
\hline 7.7 & $\begin{array}{l}115 \\
120 \\
125 \\
130 \\
135\end{array}$ & $\begin{array}{l}.553 \\
.535 \\
.535 \\
.523 \\
.529\end{array}$ & $\begin{array}{l}.0086 \\
.0121 \\
.0165 \\
.0234 \\
.0325\end{array}$ & $\begin{array}{l}-.0062 \\
-.0082 \\
-.0105 \\
-.0128 \\
-.0133\end{array}$ \\
\hline 13.8 & $\begin{array}{l}115 \\
120 \\
125 \\
130 \\
135\end{array}$ & $\begin{array}{l}.455 \\
.477 \\
.477 \\
.488 \\
.511\end{array}$ & $\begin{array}{l}.0103 \\
.0134 \\
.0182 \\
.0249 \\
.0333\end{array}$ & $\begin{array}{l}-.0078 \\
-.0095 \\
-.0123 \\
-.0141 \\
-.0146\end{array}$ \\
\hline 21.2 & $\begin{array}{l}115 \\
120 \\
125 \\
130 \\
135\end{array}$ & $\begin{array}{l}.239 \\
.304 \\
.361 \\
.410 \\
.445\end{array}$ & $\begin{array}{l}.0201 \\
.0217 \\
.0253 \\
.0306 \\
.0384\end{array}$ & $\begin{array}{l}-.0142 \\
-.0140 \\
-.0140 \\
-.0147 \\
-.0164\end{array}$ \\
\hline 29.2 & $\begin{array}{l}115 \\
120 \\
125 \\
130 \\
135\end{array}$ & $\begin{array}{l}.160 \\
.208 \\
.271 \\
.361 \\
.396\end{array}$ & $\begin{array}{l}.0319 \\
.0328 \\
.0342 \\
.0352 \\
.0436\end{array}$ & $\begin{array}{l}-.0183 \\
-.0185 \\
-.0178 \\
-.0157 \\
-.0172\end{array}$ \\
\hline 41.0 & $\begin{array}{l}115 \\
120 \\
125 \\
130 \\
135\end{array}$ & $\begin{array}{l}.109 \\
.146 \\
.194 \\
.253 \\
.318\end{array}$ & $\begin{array}{l}.0483 \\
.0484 \\
.0487 \\
.0504 \\
.0545\end{array}$ & $\begin{array}{l}-.0237 \\
-.0235 \\
-.0229 \\
-.0221 \\
-.0210\end{array}$ \\
\hline
\end{tabular}




\begin{tabular}{|c|c|c|c|c|}
\hline $\begin{array}{c}V_{\infty} * \\
(\text { meters/sec })\end{array}$ & $\begin{array}{l}P_{i}^{*} \\
(d B)\end{array}$ & $\mathrm{C}_{\mathrm{D}}$ & $\mathrm{R}_{\mathrm{o}} * / \rho^{*} \mathrm{C} *$ & $x_{t} * / \rho^{*} c^{*}$ \\
\hline 58.2 & $\begin{array}{l}115 \\
120 \\
125 \\
130 \\
135\end{array}$ & $\begin{array}{l}.076 \\
.104 \\
.133 \\
.179 \\
.233\end{array}$ & $\begin{array}{r}.0702 \\
.0680 \\
.0714 \\
.0712 \\
.0736\end{array}$ & $\begin{array}{l}-.0336 \\
-.0321 \\
-.0331 \\
-.0315 \\
-.0305\end{array}$ \\
\hline 70.9 & $\begin{array}{l}115 \\
120 \\
125 \\
130 \\
135\end{array}$ & $\begin{array}{l}.063 \\
.083 \\
.116 \\
.144 \\
.199\end{array}$ & $\begin{array}{r}.0851 \\
.0863 \\
.0826 \\
.0889 \\
.0864\end{array}$ & $\begin{array}{l}-.0388 \\
-.0389 \\
-.0366 \\
-.0384 \\
-.0360\end{array}$ \\
\hline 79.6 & $\begin{array}{l}115 \\
120 \\
125 \\
130 \\
135\end{array}$ & $\begin{array}{l}.056 \\
.071 \\
.097 \\
.130 \\
.175\end{array}$ & $\begin{array}{r}.0960 \\
.1006 \\
.0982 \\
.0986 \\
.0980\end{array}$ & $\begin{array}{l}-.0425 \\
-.0443 \\
-.0435 \\
-.0426 \\
-.0408\end{array}$ \\
\hline
\end{tabular}

Model \#12

$$
\begin{aligned}
& \mathrm{d}^{*}=2.67 \mathrm{~mm} ; \tau^{*}=0.81 \mathrm{~mm} ; \mathrm{D}^{*}=31.75 \mathrm{~mm} ; \mathrm{L}^{*}=38.10 \mathrm{~mm} \\
& \mathrm{f}_{\text {res }}^{*}=422 \mathrm{~Hz} ; \mathrm{T}_{\infty}^{*}=64^{\circ} \mathrm{F} ; \mathrm{P}_{\infty}=30.0^{\prime \prime} \mathrm{Hg} ; \mathrm{d}_{\mathrm{e}}^{*} / \mathrm{d}^{*}=1.119
\end{aligned}
$$

\begin{tabular}{|c|c|c|c|c|}
\hline $\begin{array}{c}V_{\infty}^{*} \\
(\text { meters/sec })\end{array}$ & $\begin{array}{l}\mathrm{P}_{\mathrm{i}^{*}} \\
(\mathrm{~d} \mathrm{~B})\end{array}$ & $\mathrm{C}_{\mathrm{D}}$ & $\mathrm{R}_{\mathrm{o}} * / \rho^{*} \mathrm{C}^{*}$ & $x_{t} * / p * c *$ \\
\hline 0 & $\begin{array}{r}70 \\
80 \\
90 \\
100 \\
110 \\
115 \\
120 \\
125 \\
130 \\
135\end{array}$ & $\begin{array}{l}.189 \\
.339 \\
.525 \\
.646 \\
.685 \\
.684 \\
.646 \\
.610 \\
.589 \\
.432\end{array}$ & $\begin{array}{r}.0024 \\
.0024 \\
.0027 \\
.0039 \\
.0058 \\
.0073 \\
.0103 \\
.0152 \\
.0218 \\
.0313\end{array}$ & $\begin{array}{c}0 \\
0 \\
-.0001 \\
-.0004 \\
-.0032 \\
-.0049 \\
-.0070 \\
-.0088 \\
-.0106 \\
-.0107\end{array}$ \\
\hline
\end{tabular}




\begin{tabular}{|c|c|c|c|c|}
\hline $\begin{array}{c}V_{\infty}^{*} \\
(\text { meters } / \text { sec })\end{array}$ & $\begin{array}{l}P_{i}^{*} \\
(d B)\end{array}$ & $\mathrm{C}_{\mathrm{D}}$ & $\mathrm{R}_{\mathrm{o}}^{*} / \rho^{*} \mathrm{c}^{*}$ & $X_{t}{ }^{*} / \rho^{*} c^{*}$ \\
\hline $\begin{array}{r}7.6 \\
-\end{array}$ & $\begin{array}{l}115 \\
120 \\
125 \\
130 \\
135\end{array}$ & $\begin{array}{l}.610 \\
.582 \\
.576 \\
.569 \\
.563\end{array}$ & $\begin{array}{r}.0083 \\
.0121 \\
.0168 \\
.0230 \\
.0322\end{array}$ & $\begin{array}{l}-.0053 \\
-.0065 \\
-.0080 \\
-.0099 \\
-.0102\end{array}$ \\
\hline 13.7 & $\begin{array}{l}115 \\
120 \\
125 \\
130 \\
135\end{array}$ & $\begin{array}{l}.479 \\
.507 \\
.513 \\
.543 \\
.543\end{array}$ & $\begin{array}{r}.0106 \\
.0135 \\
.0184 \\
.0240 \\
.0335\end{array}$ & $\begin{array}{l}-.0068 \\
-.0082 \\
-.0098 \\
-.0105 \\
-.0102\end{array}$ \\
\hline 21.0 & $\begin{array}{l}115 \\
120 \\
125 \\
130 \\
135\end{array}$ & $\begin{array}{l}.266 \\
.335 \\
.394 \\
.437 \\
.479\end{array}$ & $\begin{array}{r}.0195 \\
.0211 \\
.0249 \\
.0305 \\
.0381\end{array}$ & $\begin{array}{l}-.0115 \\
-.0113 \\
-.0110 \\
-.0117 \\
-.0112\end{array}$ \\
\hline 29.0 & $\begin{array}{l}115 \\
120 \\
125 \\
130 \\
135\end{array}$ & $\begin{array}{l}.197 \\
.251 \\
.306 \\
.363 \\
.422\end{array}$ & $\begin{array}{r}.0276 \\
.0290 \\
.0324 \\
.0374 \\
.0434\end{array}$ & $\begin{array}{l}-.0130 \\
-.0133 \\
-.0132 \\
-.0121 \\
-.0122\end{array}$ \\
\hline 41.1 & $\begin{array}{l}115 \\
120 \\
125 \\
130 \\
135\end{array}$ & $\begin{array}{l}.135 \\
.172 \\
.229 \\
.282 \\
.351\end{array}$ & $\begin{array}{r}.0419 \\
.0439 \\
.0442 \\
.0484 \\
.0526\end{array}$ & $\begin{array}{l}-.0152 \\
-.0157 \\
-.0150 \\
-.0146 \\
-.0124\end{array}$ \\
\hline 57.9 & $\begin{array}{l}115 \\
120 \\
125 \\
130 \\
135\end{array}$ & $\begin{array}{l}.092 \\
.120 \\
.160 \\
.197 \\
.260\end{array}$ & $\begin{array}{r}.0622 \\
.0639 \\
.0642 \\
.0700 \\
.0714\end{array}$ & $\begin{array}{l}-.0193 \\
-.0190 \\
-.0182 \\
-.0181 \\
-.0156\end{array}$ \\
\hline 70.7 & $\begin{array}{l}115 \\
120 \\
125 \\
130 \\
135\end{array}$ & $\begin{array}{l}.074 \\
.102 \\
.129 \\
.166 \\
.216\end{array}$ & $\begin{array}{r}.0719 \\
.0765 \\
.0812 \\
.0843 \\
.0866\end{array}$ & $\begin{array}{l}-.0179 \\
-.0171 \\
-.0171 \\
-.0167 \\
-.0150\end{array}$ \\
\hline 79.6 & $\begin{array}{l}115 \\
120 \\
125 \\
130 \\
135\end{array}$ & $\begin{array}{l}.062 \\
.084 \\
.116 \\
.148 \\
.195\end{array}$ & $\begin{array}{r}.0956 \\
.0935 \\
.0904 \\
.0950 \\
.0963\end{array}$ & $\begin{array}{l}-.0192 \\
-.0185 \\
-.0173 \\
-.0165 \\
-.0152\end{array}$ \\
\hline
\end{tabular}


Mode1 \#13 $\mathrm{d}^{*}=3.56 \mathrm{~mm} ; \tau *=0.25 \mathrm{~mm} ; \mathrm{D}^{*}=19.05 \mathrm{~mm} ; \mathrm{L}^{*}=38.10 \mathrm{~mm}$

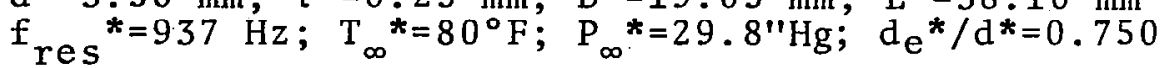

\begin{tabular}{|c|c|c|c|c|}
\hline $\begin{array}{c}V_{\infty}{ }^{*} \\
(\text { meters } / \text { sec })\end{array}$ & $\mathrm{P}_{\dot{i}_{\mathrm{d}}}^{*}$ & $\mathrm{C}_{\mathrm{D}}$ & $\mathrm{R}_{\mathrm{o}}{ }^{*} / \rho^{*} \mathrm{C} *$ & $x_{t} * / \rho * c *$ \\
\hline 0 & $\begin{array}{r}70 \\
80 \\
90 \\
100 \\
110 \\
120 \\
130 \\
135\end{array}$ & $\begin{array}{l}.159 \\
.279 \\
.482 \\
.711 \\
.737 \\
.758 \\
.805 \\
.805\end{array}$ & $\begin{array}{l}.0034 \\
.0035 \\
.0026 \\
.0043 \\
.0071 \\
.0119 \\
.0199 \\
.0267\end{array}$ & $\begin{array}{c}0 \\
0 \\
0 \\
-.0003 \\
-.0020 \\
-.0046 \\
-.0080 \\
-.0102\end{array}$ \\
\hline 17.1 & $\begin{array}{l}120 \\
130 \\
135\end{array}$ & $\begin{array}{r}.762 \\
.815 \\
.803\end{array}$ & $\begin{array}{r}.0098 \\
.0195 \\
.0270\end{array}$ & $\begin{array}{l}-.0081 \\
-.0083 \\
-.0097\end{array}$ \\
\hline 25.3 & $\begin{array}{l}120 \\
130 \\
135\end{array}$ & $\begin{array}{l}.447 \\
.697 \\
.765\end{array}$ & $\begin{array}{r}.0153 \\
.0216 \\
.0278\end{array}$ & $\begin{array}{l}-.0155 \\
-.0122 \\
-.0115\end{array}$ \\
\hline 39.0 & $\begin{array}{l}120 \\
130 \\
135\end{array}$ & $\begin{array}{l}.262 \\
.455 \\
.588\end{array}$ & $\begin{array}{r}.0322 \\
.0343 \\
.0363\end{array}$ & $\begin{array}{l}-.0181 \\
-.0163 \\
-.0145\end{array}$ \\
\hline 52.9 & $\begin{array}{l}120 \\
130 \\
135\end{array}$ & $\begin{array}{l}.186 \\
.326 \\
.435\end{array}$ & $\begin{array}{r}.0488 \\
.0499 \\
.0503\end{array}$ & $\begin{array}{r}-.0187 \\
-.0177 \\
-.0165\end{array}$ \\
\hline 63.4 & $\begin{array}{l}120 \\
130 \\
135\end{array}$ & $\begin{array}{l}.153 \\
.268 \\
.358\end{array}$ & $\begin{array}{r}.0605 \\
.0616 \\
.0620\end{array}$ & $\begin{array}{r}-.0189 \\
-.0185 \\
-.0173\end{array}$ \\
\hline 74.9 & $\begin{array}{l}120 \\
130 \\
135\end{array}$ & $\begin{array}{l}.127 \\
.227 \\
.299\end{array}$ & $\begin{array}{r}.0740 \\
.0741 \\
.0752\end{array}$ & $\begin{array}{r}-.0185 \\
-.0171 \\
-.0165\end{array}$ \\
\hline
\end{tabular}




\begin{tabular}{|c|c|c|c|c|}
\hline $\begin{array}{c}V_{\infty} * \\
(\text { meters } / \text { sec) }\end{array}$ & $\begin{array}{l}\mathrm{P}_{i}^{*} \\
\left(\mathrm{~d}^{*}\right)\end{array}$ & $\mathrm{C}_{\mathrm{D}}$ & $\mathrm{R}_{\mathrm{o}} * / \rho^{*} \mathrm{c}^{*}$ & $x_{t} * / \rho^{*} c^{*}$ \\
\hline 7.6 & $\begin{array}{l}115 \\
120 \\
125 \\
130 \\
135\end{array}$ & $\begin{array}{l}.678 \\
.640 \\
.611 \\
.590 \\
.577\end{array}$ & $\begin{array}{r}.0087 \\
.0122 \\
.0169 \\
.0227 \\
.0307\end{array}$ & $\begin{array}{l}-.0021 \\
-.0037 \\
-.0053 \\
-.0093 \\
-.0133\end{array}$ \\
\hline 13.7 & $\begin{array}{l}115 \\
120 \\
125 \\
130 \\
135\end{array}$ & $\begin{array}{l}.584 \\
.557 \\
.532 \\
.570 \\
.584\end{array}$ & $\begin{array}{l}.0069 \\
.0111 \\
.0161 \\
.0224 \\
.0299\end{array}$ & $\begin{array}{l}-.0078 \\
-.0095 \\
-.0125 \\
-.0118 \\
-.0140\end{array}$ \\
\hline 20.7 & $\begin{array}{l}115 \\
120 \\
125 \\
130 \\
135\end{array}$ & $\begin{array}{l}.214 \\
.289 \\
.368 \\
.433 \\
.491\end{array}$ & $\begin{array}{r}.0148 \\
.0169 \\
.0207 \\
.0266 \\
.0337\end{array}$ & $\begin{array}{l}-.0243 \\
-.0225 \\
-.0210 \\
-.0202 \\
-.0202\end{array}$ \\
\hline 29.3 & $\begin{array}{l}115 \\
120 \\
125 \\
130 \\
135\end{array}$ & $\begin{array}{l}.147 \\
.189 \\
.240 \\
.317 \\
.377\end{array}$ & $\begin{array}{l}.0302 \\
.0322 \\
.0358 \\
.0375 \\
.0447\end{array}$ & $\begin{array}{l}-.0286 \\
-.0286 \\
-.0274 \\
-.0260 \\
-.0250\end{array}$ \\
\hline 41.5 & $\begin{array}{l}115 \\
120 \\
125 \\
130 \\
135\end{array}$ & $\begin{array}{l}.099 \\
.135 \\
.168 \\
.227 \\
.289\end{array}$ & $\begin{array}{r}.0527 \\
.0517 \\
.0562 \\
.0572 \\
.0613\end{array}$ & $\begin{array}{l}-.0317 \\
-.0307 \\
-.0315 \\
-.0281 \\
-.0263\end{array}$ \\
\hline 57.9 & $\begin{array}{l}115 \\
120 \\
125 \\
130 \\
135\end{array}$ & $\begin{array}{l}.072 \\
.097 \\
.126 \\
.174 \\
.214\end{array}$ & $\begin{array}{l}.0793 \\
.0767 \\
.0781 \\
.0754 \\
.0829\end{array}$ & $\begin{array}{l}-.0305 \\
-.0343 \\
-.0359 \\
-.0348 \\
-.0351\end{array}$ \\
\hline 70.7 & $\begin{array}{l}115 \\
120 \\
125 \\
130 \\
135\end{array}$ & $\begin{array}{l}.056 \\
.074 \\
.104 \\
.126 \\
.182\end{array}$ & $\begin{array}{l}.1014 \\
.1033 \\
.0983 \\
.1080 \\
.0996\end{array}$ & $\begin{array}{l}-.0377 \\
-.0362 \\
-.0354 \\
-.0383 \\
-.0354\end{array}$ \\
\hline 79.2 & $\begin{array}{l}115 \\
120 \\
125 \\
130 \\
135\end{array}$ & $\begin{array}{l}.048 \\
.065 \\
.089 \\
.116 \\
.168\end{array}$ & $\begin{array}{r}.1218 \\
.1188 \\
.1162 \\
.1189 \\
.1094\end{array}$ & $\begin{array}{l}-.0364 \\
-.0363 \\
-.0352 \\
-.0358 \\
-.0340\end{array}$ \\
\hline
\end{tabular}


Mode1 \#16 $\mathrm{d}^{*}=7.11 \mathrm{~mm} ; \tau^{*}=2.03 \mathrm{~mm} ; \mathrm{D}^{*}=31.75 \mathrm{~mm} ; \mathrm{L} *=25.4 \mathrm{~mm}$ $\mathrm{f}_{\text {res }}^{*}=892 \mathrm{~Hz} ; \mathrm{T}_{\infty}^{*}=83^{\circ} \mathrm{F} ; \mathrm{P}_{\infty}^{*}=29.8{ }^{\prime \prime} \mathrm{Hg} ; \mathrm{d}_{\mathrm{e}}^{*} / \mathrm{d}^{*}=0.988$

\begin{tabular}{|c|c|c|c|c|}
\hline $\begin{array}{c}V_{\infty}^{*} \\
(\text { meters/sec) }\end{array}$ & $\begin{array}{l}\mathrm{P}_{j} * \\
(\mathrm{~dB})\end{array}$ & $\mathrm{C}_{\mathrm{D}}$ & $\mathrm{R}_{\mathrm{o}} * / \rho * \mathrm{C} *$ & $x_{t} * / \rho * c *$ \\
\hline 0 & $\begin{array}{r}70 \\
80 \\
90 \\
100 \\
110 \\
120 \\
130 \\
135 \\
140\end{array}$ & $\begin{array}{l}.130 \\
.230 \\
.393 \\
.612 \\
.764 \\
.726 \\
.754 \\
.761 \\
.745\end{array}$ & $\begin{array}{l}.0037 \\
.0037 \\
.0038 \\
.0044 \\
.0062 \\
.0115 \\
.0198 \\
.0263 \\
.0354\end{array}$ & $\begin{array}{c}0 \\
0 \\
0 \\
+.0001 \\
+.0007 \\
+.0019 \\
+.0024 \\
+.0009 \\
-.0059\end{array}$ \\
\hline 25.0 & $\begin{array}{l}120 \\
130 \\
135 \\
140\end{array}$ & $\begin{array}{l}.893 \\
.814 \\
.759 \\
.708\end{array}$ & $\begin{array}{l}.0073 \\
.0180 \\
.0260 \\
.0370\end{array}$ & $\begin{array}{l}-.0058 \\
-.0042 \\
-.0046 \\
-.0075\end{array}$ \\
\hline 53.0 & $\begin{array}{l}120 \\
130 \\
135 \\
140\end{array}$ & $\begin{array}{l}.131 \\
.230 \\
.313 \\
.395\end{array}$ & $\begin{array}{r}.0464 \\
.0495 \\
.0498 \\
.0555\end{array}$ & $\begin{array}{l}-.0452 \\
-.0430 \\
-.0403 \\
-.0389\end{array}$ \\
\hline 75.6 & $\begin{array}{l}120 \\
130 \\
135 \\
140\end{array}$ & $\begin{array}{l}.087 \\
.160 \\
.211 \\
.269\end{array}$ & $\begin{array}{r}.0884 \\
.0840 \\
.0847 \\
.0890\end{array}$ & $\begin{array}{l}-.0412 \\
-.0419 \\
-.0431 \\
-.0444\end{array}$ \\
\hline
\end{tabular}




\section{APPENDIX B}

Summary of frequency sweep data for special mode1 for $V_{\infty}{ }^{*}=60$ meters $/ \mathrm{sec}$ and $\mathrm{P}_{\mathrm{i}}^{*}=120 \mathrm{~dB}$

$\mathrm{d}^{*}=1.02 \mathrm{~mm} ; \tau^{*}=0.81 \mathrm{~mm} ; \mathrm{D}^{*}=19.05 \mathrm{~mm} ; \mathrm{L}^{*}=25.4 \mathrm{~mm}$

$f_{\text {res }}{ }^{*}=590 \mathrm{~Hz} ; \mathrm{T}_{\infty}^{*}=64^{\circ} \mathrm{F} ; \mathrm{P}_{\infty}{ }^{*}=30.2^{\prime \prime} \mathrm{Hg} ; \mathrm{d}_{\mathrm{e}}{ }^{*} / \mathrm{d}^{*}=2.060$

\begin{tabular}{rlcccc}
$\begin{array}{c}f^{*} \\
(\mathrm{~Hz})\end{array}$ & $\left|\mathrm{P}_{\mathrm{C}}^{*} / \mathrm{P}_{\mathrm{i}}^{*}\right|$ & $\begin{array}{c}\phi_{\mathrm{i} C}^{*} \\
(\mathrm{deg})\end{array}$ & $\mathrm{C}_{\mathrm{D}}$ & $\mathrm{R}_{\mathrm{O}}^{*} / \rho^{*} \mathrm{C}^{*}$ & $\mathrm{X}_{\mathrm{t}}^{*} / \rho^{*} \mathrm{C}^{*}$ \\
\hline 350 & .324 & 77.5 & .135 & .0556 & -.0123 \\
400 & .288 & 80.2 & .138 & .0552 & -.0095 \\
450 & .254 & 83.8 & .137 & .0563 & -.0061 \\
500 & .226 & 86.4 & .135 & .0547 & -.0036 \\
550 & .204 & 88.4 & .134 & .0578 & -.0016 \\
600 & .195 & 91.1 & .140 & .0556 & .0111 \\
650 & .188 & 92.4 & .146 & .0532 & .0022 \\
700 & .168 & 94.9 & .140 & .0554 & .0048 \\
750 & .155 & 96.8 & .139 & .0560 & .0067 \\
800 & .150 & 98.9 & .143 & .0543 & .0085 \\
850 & .140 & 100.6 & .142 & .0546 & .0102 \\
900 & .136 & 104.4 & .147 & .0522 & .0134 \\
950 & .124 & 104.7 & .141 & .0543 & .0142 \\
1000 & .123 & 107.7 & .147 & .0516 & .0165 \\
1050 & .117 & 108 & .147 & .0515 & .0167
\end{tabular}




\section{APPENDIX C - THICK ORIFICE DATA}

The two-microphone impedance test data is summarized herein for the six thick orifice resonator configurations described in Table II. The data is presented in a manner similar to that of Appendix A. 
Mode1 \#1 $\quad \mathrm{d}^{*}=1.78 \mathrm{~mm} ; \tau^{*}=0.51 \mathrm{~mm} ; \mathrm{D}^{*}=31.75 \mathrm{~mm} ; L^{*}=12.7 \mathrm{~mm}$; $\mathrm{f}_{\text {res }}^{*}=552 \mathrm{~Hz} ; \mathrm{T}_{\infty}^{*}=66^{\circ} \mathrm{F} ; \mathrm{P}_{\infty}^{*}=30.1^{\prime \prime} \mathrm{Hg}$

\begin{tabular}{|c|c|c|c|c|}
\hline $\begin{array}{c}V_{\infty}{ }^{*} \\
(\text { meters } / \text { sec })\end{array}$ & $\begin{array}{l}P_{i} \\
d B\end{array}$ & $\mathrm{C}_{\mathrm{D}}$ & $\mathrm{R}_{\mathrm{o}}^{*} / \rho^{*} \mathrm{C}^{*}$ & $X_{t} * / \rho^{*} c^{*}$ \\
\hline 0 & $\begin{array}{r}70 \\
115 \\
120 \\
125 \\
130 \\
135 \\
140\end{array}$ & $\begin{array}{l}.116 \\
.575 \\
.549 \\
.536 \\
.542 \\
.536 \\
.549\end{array}$ & $\begin{array}{r}.0037 \\
.0087 \\
.0123 \\
.0174 \\
.0238 \\
.0330 \\
.0436\end{array}$ & $\begin{array}{c}0 \\
-.0051 \\
-.0068 \\
-.0081 \\
-.0085 \\
-.0087 \\
-.0089\end{array}$ \\
\hline 7.9 & $\begin{array}{l}120 \\
125 \\
130 \\
135 \\
140\end{array}$ & $\begin{array}{l}.524 \\
.524 \\
.530 \\
.542 \\
.542\end{array}$ & $\begin{array}{r}.0132 \\
.0182 \\
.0247 \\
.0328 \\
.0441\end{array}$ & $\begin{array}{l}-.0065 \\
-.0073 \\
-.0078 \\
-.0081 \\
-.0089\end{array}$ \\
\hline 13.7 & $\begin{array}{l}120 \\
125 \\
130 \\
135 \\
140\end{array}$ & $\begin{array}{l}.489 \\
.506 \\
.524 \\
.542 \\
.549\end{array}$ & $\begin{array}{r}.0142 \\
.0187 \\
.0248 \\
.0327 \\
.0437\end{array}$ & $\begin{array}{l}-.0068 \\
-.0080 \\
-.0084 \\
-.0082 \\
-.0086\end{array}$ \\
\hline 20.1 & $\begin{array}{l}120 \\
125 \\
130 \\
135 \\
140\end{array}$ & $\begin{array}{l}.375 \\
.431 \\
.467 \\
.506 \\
.530\end{array}$ & $\begin{array}{r}.0186 \\
.0221 \\
.0277 \\
.0348 \\
.0450\end{array}$ & $\begin{array}{l}-.0088 \\
-.0091 \\
-.0099 \\
-.0097 \\
-.0099\end{array}$ \\
\hline 29.0 & $\begin{array}{l}120 \\
125 \\
130 \\
135 \\
140\end{array}$ & $\begin{array}{l}.275 \\
.350 \\
.407 \\
.456 \\
.500\end{array}$ & $\begin{array}{r}.0264 \\
.0276 \\
.0321 \\
.0386 \\
.0475\end{array}$ & $\begin{array}{l}-.0096 \\
-.0100 \\
-.0105 \\
-.0109 \\
-.0111\end{array}$ \\
\hline 41.2 & $\begin{array}{l}120 \\
125 \\
130 \\
135 \\
140\end{array}$ & $\begin{array}{l}.197 \\
.254 \\
.316 \\
.389 \\
.462\end{array}$ & $\begin{array}{r}.0374 \\
.0391 \\
.0419 \\
.0457 \\
.0515\end{array}$ & $\begin{array}{l}-.0101 \\
-.0108 \\
-.0117 \\
-.0116 \\
-.0121\end{array}$ \\
\hline 58.2 & $\begin{array}{l}120 \\
125 \\
130 \\
135 \\
140\end{array}$ & $\begin{array}{l}.132 \\
.190 \\
.237 \\
.312 \\
.380\end{array}$ & $\begin{array}{r}.0573 \\
.0530 \\
.0566 \\
.0572 \\
.0627\end{array}$ & $\begin{array}{l}-.0124 \\
-.0108 \\
-.0126 \\
-.0127 \\
-.0140\end{array}$ \\
\hline
\end{tabular}


$\stackrel{V_{\infty}^{*}}{(\text { meters }} \stackrel{\text { sec })}{ }$

$\mathrm{P}_{\mathbf{i}} *$

$\mathrm{C}_{\mathrm{D}}$ *

$\mathrm{R}_{\mathrm{o}} * / \rho * \mathrm{c} *$

$x_{t}^{*} / \rho * c *$

$\begin{array}{llll}120 & .117 & .0646 & -.0126 \\ 125 & .151 & .0670 & -.0124 \\ 130 & .204 & .0660 & -.0132 \\ 135 & .257 & .0699 & -.0141 \\ 140 & .338 & .0706 & -.0150 \\ 120 & .098 & .0779 & -.0137 \\ 125 & .138 & .0735 & -.0131 \\ 130 & .174 & .0778 & -.0143 \\ 135 & .221 & .0814 & -.0152 \\ 140 & .305 & .0786 & -.0151\end{array}$

Mode1 \#2 $\mathrm{d}^{*}=1.78 \mathrm{~mm} ; \tau^{*}=1.015 \mathrm{~mm} ; \mathrm{D}^{*}=31.75 \mathrm{~mm} ; \mathrm{L}^{*}=12.7 \mathrm{~mm}$; $\mathrm{f}_{\text {res }}^{*}=530 \mathrm{~Hz} ; \mathrm{T}_{\infty}{ }^{*}=73^{\circ} \mathrm{F} ; \mathrm{P}_{\infty}=30.07 " \mathrm{Hg}$

\begin{tabular}{|c|c|c|c|c|}
\hline $\begin{array}{c}V_{\infty} * \\
(\operatorname{meters} / \sec )\end{array}$ & $\mathrm{P}_{\dot{i}} *$ & $\mathrm{C}_{\mathrm{D}}$ & $\mathrm{R}_{0} * / \rho{ }^{*} \mathrm{C}^{*}$ & $X_{t} * / \rho^{*} c^{*}$ \\
\hline 0 & $\begin{array}{r}70 \\
115 \\
120 \\
125 \\
130 \\
135 \\
140\end{array}$ & $\begin{array}{l}.119 \\
.731 \\
.714 \\
.714 \\
.698 \\
.659 \\
.674\end{array}$ & $\begin{array}{r}.0037 \\
.0071 \\
.0095 \\
.0128 \\
.0178 \\
.0265 \\
.0352\end{array}$ & $\begin{array}{c}0 \\
-.0035 \\
-.0051 \\
-.0065 \\
-.0083 \\
-.0084 \\
-.0083\end{array}$ \\
\hline 7.9 & $\begin{array}{l}120 \\
125 \\
130 \\
135 \\
140\end{array}$ & $\begin{array}{l}.690 \\
.690 \\
.667 \\
.659 \\
.659\end{array}$ & $\begin{array}{r}.0100 \\
.0135 \\
.0187 \\
.0263 \\
.0360\end{array}$ & $\begin{array}{l}-.0050 \\
-.0063 \\
-.0085 \\
-.0088 \\
-.0089\end{array}$ \\
\hline 13.7 & $\begin{array}{l}120 \\
125 \\
130 \\
135 \\
140\end{array}$ & $\begin{array}{l}.615 \\
.622 \\
.629 \\
.629 \\
.651\end{array}$ & $\begin{array}{l}.0110 \\
.0146 \\
.0197 \\
.0273 \\
.0362\end{array}$ & $\begin{array}{l}-.0060 \\
-.0078 \\
-.0093 \\
-.0099 \\
-.0098\end{array}$ \\
\hline
\end{tabular}




\begin{tabular}{|c|c|c|c|c|}
\hline $\begin{array}{c}V_{\infty} \\
(\text { meters } / \text { sec })\end{array}$ & $\begin{array}{l}\mathrm{P}_{i} * \\
(\mathrm{~d} B)\end{array}$ & $\mathrm{C}_{\mathrm{D}}$ & $\mathrm{R}_{\mathrm{o}} * / \rho * \mathrm{c} *$ & $X_{t} * / \rho^{*} c^{*}$ \\
\hline 20.1 & $\begin{array}{l}120 \\
125 \\
130 \\
135 \\
140\end{array}$ & $\begin{array}{l}.393 \\
.456 \\
.512 \\
.574 \\
.601\end{array}$ & $\begin{array}{r}.0175 \\
.0206 \\
.0251 \\
.0302 \\
.0392\end{array}$ & $\begin{array}{l}-.0089 \\
-.0092 \\
-.0094 \\
-.0102 \\
-.0105\end{array}$ \\
\hline 28.7 & $\begin{array}{l}120 \\
125 \\
130 \\
135 \\
140\end{array}$ & $\begin{array}{l}.284 \\
.354 \\
.421 \\
.512 \\
.567\end{array}$ & $\begin{array}{r}.0254 \\
.0272 \\
.0310 \\
.0344 \\
.0416\end{array}$ & $\begin{array}{l}-.0095 \\
-.0102 \\
-.0103 \\
-.0097 \\
-.0109\end{array}$ \\
\hline 41.5 & $\begin{array}{l}120 \\
125 \\
130 \\
135 \\
140\end{array}$ & $\begin{array}{l}.201 \\
.259 \\
.319 \\
.411 \\
.488\end{array}$ & $\begin{array}{r}.0372 \\
.0383 \\
.0415 \\
.0432 \\
.0486\end{array}$ & $\begin{array}{r}-.0093 \\
-.0105 \\
-.0113 \\
-.0108 \\
-.0117\end{array}$ \\
\hline 58.2 & $\begin{array}{l}120 \\
125 \\
130 \\
135 \\
140\end{array}$ & $\begin{array}{l}.136 \\
.181 \\
.234 \\
.323 \\
.411\end{array}$ & $\begin{array}{r}.0557 \\
.0558 \\
.0575 \\
.0555 \\
.0582\end{array}$ & $\begin{array}{l}-.0107 \\
-.0100 \\
-.0120 \\
-.0117 \\
-.0117\end{array}$ \\
\hline 71.3 & $\begin{array}{l}120 \\
125 \\
130 \\
135 \\
140\end{array}$ & $\begin{array}{l}.109 \\
.144 \\
.201 \\
.251 \\
.330\end{array}$ & $\begin{array}{r}.0695 \\
.0705 \\
.0670 \\
.0719 \\
.0726\end{array}$ & $\begin{array}{l}-.0123 \\
-.0110 \\
-.0124 \\
-.0129 \\
-.0137\end{array}$ \\
\hline 79.9 & $\begin{array}{l}120 \\
125 \\
130 \\
135 \\
140\end{array}$ & $\begin{array}{l}.095 \\
.130 \\
.167 \\
.228 \\
.298\end{array}$ & $\begin{array}{r}.0800 \\
.0783 \\
.0809 \\
.0790 \\
.0808\end{array}$ & $\begin{array}{l}-.0128 \\
-.0120 \\
-.0130 \\
-.0132 \\
-.0140\end{array}$ \\
\hline
\end{tabular}


Mode 1 \#3

$$
\begin{aligned}
& \mathrm{d}^{*}=1.78 \mathrm{~mm} ; \mathrm{\tau}^{*}=2.032 \mathrm{~mm} ; \mathrm{D}^{*}=31.75 \mathrm{~mm} ; \mathrm{L}^{*}=12.7 \mathrm{~mm} ; \\
& \mathrm{f}_{\text {res }}{ }^{*}=414 \mathrm{~Hz} ; \mathrm{T}_{\infty}{ }^{*}=66^{\circ} \mathrm{F} ; \mathrm{P}_{\infty}{ }^{*}=29.55^{\prime \prime H g}
\end{aligned}
$$

\begin{tabular}{|c|c|c|c|c|}
\hline $\begin{array}{c}V_{\infty} * \\
(\operatorname{meters} / \text { sec })\end{array}$ & $\begin{array}{l}\mathrm{P}_{i} * \\
(\mathrm{~dB})\end{array}$ & $\mathrm{C}_{\mathrm{D}}$ & $\mathrm{R}_{0}{ }^{*} / \mathrm{p}^{*} \mathrm{C} *$ & $x_{t} * / \rho^{*} c^{*}$ \\
\hline 0 & $\begin{array}{r}70 \\
115 \\
120 \\
125 \\
130 \\
135\end{array}$ & $\begin{array}{l}.058 \\
.465 \\
.481 \\
.487 \\
.504 \\
.504\end{array}$ & $\begin{array}{l}.0084 \\
.0119 \\
.0147 \\
.0195 \\
.0251 \\
.0341\end{array}$ & $\begin{array}{c}0 \\
-.0038 \\
-.0062 \\
-.0086 \\
-.0110 \\
-.0131\end{array}$ \\
\hline 7.9 & $\begin{array}{l}115 \\
120 \\
125 \\
130 \\
135\end{array}$ & $\begin{array}{l}.460 \\
.470 \\
.481 \\
.504 \\
.510\end{array}$ & $\begin{array}{l}.0119 \\
.0156 \\
.0200 \\
.0257 \\
.0343\end{array}$ & $\begin{array}{l}-.0044 \\
-.0064 \\
-.0078 \\
-.0095 \\
-.0114\end{array}$ \\
\hline 13.6 & $\begin{array}{l}115 \\
120 \\
125 \\
130 \\
135\end{array}$ & $\begin{array}{l}.410 \\
.449 \\
.476 \\
.510 \\
.516\end{array}$ & $\begin{array}{l}.0133 \\
.0157 \\
.0202 \\
.0253 \\
.0340\end{array}$ & $\begin{array}{l}-.0049 \\
-.0067 \\
-.0081 \\
-.0096 \\
-.0110\end{array}$ \\
\hline 20. & $\begin{array}{l}115 \\
120 \\
125 \\
130 \\
135\end{array}$ & $\begin{array}{l}.259 \\
.357 \\
.424 \\
.476 \\
.493\end{array}$ & $\begin{array}{l}.0213 \\
.0205 \\
.0230 \\
.0273 \\
.0356\end{array}$ & $\begin{array}{l}-.0073 \\
-.0066 \\
-.0082 \\
-.0097 \\
-.0114\end{array}$ \\
\hline 28.3 & $\begin{array}{l}115 \\
120 \\
125 \\
130 \\
135\end{array}$ & $\begin{array}{l}.177 \\
.233 \\
.357 \\
.434 \\
.481\end{array}$ & $\begin{array}{l}.0316 \\
.0314 \\
.0278 \\
.0301 \\
.0365\end{array}$ & $\begin{array}{l}-.0091 \\
-.0100 \\
-.0082 \\
-.0103 \\
-.0116\end{array}$ \\
\hline 41 & $\begin{array}{l}115 \\
120 \\
125 \\
130 \\
135\end{array}$ & $\begin{array}{l}.136 \\
.173 \\
.239 \\
.337 \\
.424\end{array}$ & $\begin{array}{l}.0417 \\
.0431 \\
.0421 \\
.0397 \\
.0414\end{array}$ & $\begin{array}{l}-.0101 \\
-.0108 \\
-.0104 \\
-.0103 \\
-.0132\end{array}$ \\
\hline 57.6 & $\begin{array}{l}115 \\
120 \\
125 \\
130 \\
135\end{array}$ & $\begin{array}{l}.101 \\
.129 \\
.177 \\
.225 \\
.293\end{array}$ & $\begin{array}{l}.0565 \\
.0576 \\
.0570 \\
.0594 \\
.0611\end{array}$ & $\begin{array}{l}-.0125 \\
-.0137 \\
-.0133 \\
-.0150 \\
-.0143\end{array}$ \\
\hline
\end{tabular}




\begin{tabular}{ccccc}
\hline $\begin{array}{c}\mathrm{V}_{\infty}^{*} \\
\text { (meters/sec) }\end{array}$ & $\begin{array}{l}\mathrm{P}_{i}^{*} \\
(\mathrm{~dB})\end{array}$ & $\mathrm{C}_{\mathrm{D}}$ & $\mathrm{R}_{\mathrm{o}}^{*} / \rho^{*} \mathrm{C}^{*}$ & $\mathrm{X}_{\mathrm{t}}^{*} / \rho^{*} \mathrm{C}^{*}$ \\
\hline 70.1 & 120 & .103 & .0727 & -.0168 \\
& 125 & .136 & .0746 & -.0161 \\
& 130 & .183 & .0736 & -.0167 \\
78.3 & 135 & .236 & .0764 & -.0162 \\
& 120 & .092 & .0820 & -.0168 \\
& 125 & .118 & .0858 & -.0179 \\
& 130 & .165 & .0818 & -.0177 \\
& 135 & .218 & .0829 & -.0170 \\
\hline
\end{tabular}

Mode1 \#4 $\mathrm{d}^{*}=1.78 \mathrm{~mm} ; \mathrm{\tau}^{*}=4.065 \mathrm{~mm} ; \mathrm{D}^{*}=31.75 \mathrm{~mm} ; \mathrm{L}=12.7 \mathrm{~mm}$ $\mathrm{f}_{\text {res }}^{*}=333 \mathrm{~Hz} ; \mathrm{T}_{\infty}^{*}=75^{\circ} \mathrm{F} ; \mathrm{P}_{\infty}^{*}=30.1^{\prime \prime} \mathrm{Hg}$

\begin{tabular}{|c|c|c|c|c|}
\hline $\begin{array}{c}V_{\infty} * \\
(\text { meters/sec })\end{array}$ & $\begin{array}{l}\mathrm{P}_{\dot{i}^{*}}^{*} \\
\left(\dot{d}^{\mathrm{a} B}\right)\end{array}$ & $\mathrm{C}_{\mathrm{D}}$ & $\mathrm{R}_{\mathrm{O}}{ }^{*} / \rho^{*} \mathrm{C} *$ & $X_{t} * / \rho * c *$ \\
\hline 0 & $\begin{array}{r}70 \\
115 \\
120 \\
125 \\
130\end{array}$ & $\begin{array}{l}.049 \\
.467 \\
.489 \\
.524 \\
.578\end{array}$ & $\begin{array}{r}.0087 \\
.0121 \\
.0151 \\
.0187 \\
.0254\end{array}$ & $\begin{array}{r}0 \\
-.0025 \\
-.0042 \\
-.0058 \\
-.0070\end{array}$ \\
\hline 7.6 & $\begin{array}{l}115 \\
120 \\
125 \\
130\end{array}$ & $\begin{array}{l}.457 \\
.484 \\
.524 \\
.518\end{array}$ & $\begin{array}{r}.0123 \\
.0153 \\
.0188 \\
.0255\end{array}$ & $\begin{array}{l}-.0029 \\
-.0041 \\
-.0054 \\
-.0067\end{array}$ \\
\hline 13.7 & $\begin{array}{l}115 \\
120 \\
125 \\
130\end{array}$ & $\begin{array}{l}.417 \\
.457 \\
.484 \\
.513\end{array}$ & $\begin{array}{r}.0135 \\
.0162 \\
.0202 \\
.0256\end{array}$ & $\begin{array}{l}-.0031 \\
-.0045 \\
-.0062 \\
-.0073\end{array}$ \\
\hline 20.1 & $\begin{array}{l}115 \\
120 \\
125 \\
130\end{array}$ & $\begin{array}{l}.278 \\
.371 \\
.441 \\
.473\end{array}$ & $\begin{array}{l}.0204 \\
.0201 \\
.0224 \\
.0279\end{array}$ & $\begin{array}{l}-.0033 \\
-.0047 \\
-.0062 \\
-.0075\end{array}$ \\
\hline
\end{tabular}




\begin{tabular}{|c|c|c|c|c|}
\hline $\begin{array}{c}\mathrm{V}_{\infty}{ }^{*} \\
(\text { meters/sec) }\end{array}$ & $\mathrm{P}_{i}^{*}{ }_{(\mathrm{d} B)}$ & $\mathrm{C}_{\mathrm{D}}$ & $\mathrm{R}_{\mathrm{o}}{ }^{*} / \rho^{*} \mathrm{C}^{*}$ & $X_{t}{ }^{*} / \rho^{*} c^{*}$ \\
\hline 28.7 & $\begin{array}{l}115 \\
120 \\
125 \\
130\end{array}$ & $\begin{array}{l}.176 \\
.266 \\
.367 \\
.431\end{array}$ & $\begin{array}{l}.0324 \\
.0281 \\
.0271 \\
.0308\end{array}$ & $\begin{array}{l}-.0050 \\
-.0067 \\
-.0065 \\
-.0076\end{array}$ \\
\hline 41.5 & $\begin{array}{l}115 \\
120 \\
125 \\
130\end{array}$ & $\begin{array}{l}.120 \\
.168 \\
.251 \\
.335\end{array}$ & $\begin{array}{l}.0475 \\
.0454 \\
.0406 \\
.0400\end{array}$ & $\begin{array}{l}-.0066 \\
-.0057 \\
-.0041 \\
-.0079\end{array}$ \\
\hline 58.2 & $\begin{array}{l}115 \\
120 \\
125 \\
130\end{array}$ & $\begin{array}{l}.091 \\
.116 \\
.162 \\
.232\end{array}$ & $\begin{array}{l}.0628 \\
.0657 \\
.0628 \\
.0588\end{array}$ & $\begin{array}{l}-.0072 \\
-.0078 \\
-.0072 \\
-.0047\end{array}$ \\
\hline 70.4 & $\begin{array}{l}115 \\
120 \\
125 \\
130\end{array}$ & $\begin{array}{l}.072 \\
.095 \\
.127 \\
.174\end{array}$ & $\begin{array}{l}.0802 \\
.0800 \\
.0802 \\
.0782\end{array}$ & $\begin{array}{l}-.0063 \\
-.0083 \\
-.0060 \\
-.0081\end{array}$ \\
\hline 79.6 & $\begin{array}{l}115 \\
120 \\
125 \\
130\end{array}$ & $\begin{array}{l}.061 \\
.086 \\
.112 \\
.150\end{array}$ & $\begin{array}{l}.0943 \\
.0889 \\
.0911 \\
.0909\end{array}$ & $\begin{array}{l}-.0063 \\
-.0078 \\
-.0064 \\
-.0084\end{array}$ \\
\hline
\end{tabular}

Mode1 \# $5 \quad \mathrm{~d}^{*}=1.78 \mathrm{~mm} ; \tau^{*}=8.127 \mathrm{~mm} ; \mathrm{D}^{*}=31.75 \mathrm{~mm} ; \mathrm{L}^{*}=12.7 \mathrm{~mm}$; $\mathrm{f}_{\text {res }}^{*}=255 \mathrm{~Hz} ; \mathrm{T}_{\infty}^{*}=74^{\circ} \mathrm{F} ; \mathrm{P}_{\infty}^{*}=30.1^{\prime \prime} \mathrm{Hg}$

\begin{tabular}{|c|c|c|c|c|}
\hline $\begin{array}{c}V_{\infty}{ }^{*} \\
(\text { meters/sec })\end{array}$ & $\begin{array}{l}\mathrm{P}_{\mathbf{i}^{*}} \\
(\mathrm{~dB})\end{array}$ & $\mathrm{C}_{\mathrm{D}}$ & $\mathrm{R}_{\mathrm{o}}{ }^{*} / \rho^{*} \mathrm{c}^{*}$ & $X_{t} * / \rho * c *$ \\
\hline 0 & $\begin{array}{r}70 \\
115 \\
120 \\
125 \\
130 \\
135\end{array}$ & $\begin{array}{l}.030 \\
.338 \\
.330 \\
.362 \\
.379 \\
.393\end{array}$ & $\begin{array}{r}.0169 \\
.0228 \\
.0277 \\
.0354 \\
.0454\end{array}$ & $\begin{array}{l}-.0019 \\
-.0045 \\
-.0054 \\
-.0062 \\
-.0074\end{array}$ \\
\hline
\end{tabular}




\begin{tabular}{|c|c|c|c|c|}
\hline $\begin{array}{c}\mathrm{V}_{\infty} * \\
(\operatorname{meters} / \mathrm{sec})\end{array}$ & $\mathrm{P}_{i^{i}}^{*}$ & $\mathrm{C}_{\mathrm{D}}$ & $\mathrm{R}_{\mathrm{o}}^{*} / \rho^{*} \mathrm{C}^{*}$ & $X_{t} * / \rho^{*} c^{*}$ \\
\hline 7.6 & $\begin{array}{l}115 \\
120 \\
125 \\
130 \\
135\end{array}$ & $\begin{array}{r}.305 \\
.330 \\
.375 \\
.393 \\
.411\end{array}$ & $\begin{array}{r}.0184 \\
.0227 \\
.0267 \\
.0340 \\
.0435\end{array}$ & $\begin{array}{l}-.0041 \\
-.0049 \\
-.0058 \\
-.0069 \\
-.0081\end{array}$ \\
\hline 13.7 & $\begin{array}{l}115 \\
120 \\
125 \\
130 \\
135\end{array}$ & $\begin{array}{l}.281 \\
.327 \\
.371 \\
.388 \\
.406\end{array}$ & $\begin{array}{l}.0202 \\
.0231 \\
.0269 \\
.0343 \\
.0438\end{array}$ & $\begin{array}{l}-.0033 \\
-.0045 \\
-.0061 \\
-.0076 \\
-.0091\end{array}$ \\
\hline 20.7 & $\begin{array}{l}115 \\
120 \\
125 \\
130 \\
135\end{array}$ & $\begin{array}{r}.208 \\
.281 \\
.354 \\
.379 \\
.397\end{array}$ & $\begin{array}{r}.0274 \\
.0270 \\
.0285 \\
.0354 \\
.0450\end{array}$ & $\begin{array}{l}-.0036 \\
-.0038 \\
-.0049 \\
-.0066 \\
-.0086\end{array}$ \\
\hline 29.0 & $\begin{array}{l}115 \\
120 \\
125 \\
130 \\
135\end{array}$ & $\begin{array}{r}.149 \\
.216 \\
.308 \\
.366 \\
.393\end{array}$ & $\begin{array}{l}.0381 \\
.0353 \\
.0329 \\
.0367 \\
.0456\end{array}$ & $\begin{array}{l}-.0055 \\
-.0038 \\
-.0042 \\
-.0063 \\
-.0082\end{array}$ \\
\hline 41.1 & $\begin{array}{l}115 \\
120 \\
125 \\
130 \\
135\end{array}$ & $\begin{array}{l}.113 \\
.149 \\
.223 \\
.308 \\
.371\end{array}$ & $\begin{array}{r}.0505 \\
.0510 \\
.0456 \\
.0439 \\
.0485\end{array}$ & $\begin{array}{l}-.0052 \\
-.0060 \\
-.0045 \\
-.0052 \\
-.0073\end{array}$ \\
\hline 57.9 & $\begin{array}{l}115 \\
120 \\
125 \\
130 \\
135\end{array}$ & $\begin{array}{r}.085 \\
.112 \\
.153 \\
.211 \\
.312\end{array}$ & $\begin{array}{r}.0673 \\
.0683 \\
.0667 \\
.0644 \\
.0580\end{array}$ & $\begin{array}{l}-.0077 \\
-.0054 \\
-.0062 \\
-.0059 \\
-.0060\end{array}$ \\
\hline 70.4 & $\begin{array}{l}115 \\
120 \\
125 \\
130 \\
135\end{array}$ & $\begin{array}{r}.071 \\
.092 \\
.124 \\
.188 \\
.248\end{array}$ & $\begin{array}{r}.0800 \\
.0831 \\
.0820 \\
.0810 \\
.0732\end{array}$ & $\begin{array}{l}-.0091 \\
-.0067 \\
-.0079 \\
-.0057 \\
-.0061\end{array}$ \\
\hline 79.2 & $\begin{array}{l}115 \\
120 \\
125 \\
130 \\
135\end{array}$ & $\begin{array}{l}.062 \\
.082 \\
.111 \\
.144 \\
.211\end{array}$ & $\begin{array}{r}.0918 \\
.0930 \\
.0920 \\
.0941 \\
.0859\end{array}$ & $\begin{array}{l}-.0109 \\
-.0095 \\
-.0087 \\
-.0094 \\
-.0081\end{array}$ \\
\hline
\end{tabular}


Mode1 \#6 $\mathrm{d}^{*}=1.78 \mathrm{~mm} ; *=15.875 \mathrm{~mm} ; \mathrm{D}^{*}=31.75 \mathrm{~mm} ; \mathrm{L}^{*}=12.7 \mathrm{~mm}$; $\mathrm{f}_{\text {res }}^{*}=197 \mathrm{~Hz} ; \mathrm{T}_{\infty}^{*}=66^{\circ} \mathrm{F} ; \mathrm{P}_{\infty}^{*}=30.1^{\prime \prime} \mathrm{Hg}$

\begin{tabular}{|c|c|c|c|c|}
\hline $\begin{array}{c}\mathrm{V}_{\infty}{ }^{*} \\
(\text { meters/sec) }\end{array}$ & $\begin{array}{l}\mathrm{P}_{\dot{i}}^{*} \\
(\mathrm{~d} B)\end{array}$ & $\mathrm{C}_{\mathrm{D}}$ & $\mathrm{R}_{\mathrm{o}} * / \rho^{*} \mathrm{c}^{*}$ & $x_{t}{ }^{*} / \rho^{*} c^{*}$ \\
\hline 0 & $\begin{array}{r}70 \\
110 \\
115 \\
120\end{array}$ & $\begin{array}{l}.0155 \\
.155 \\
.204 \\
.260\end{array}$ & $\begin{array}{l}.0275 \\
.0278 \\
.0282 \\
.0295\end{array}$ & $\begin{array}{c}0 \\
.0007 \\
.0007 \\
.0006\end{array}$ \\
\hline 7.6 & $\begin{array}{l}110 \\
115 \\
120\end{array}$ & $\begin{array}{l}.158 \\
.206 \\
.257\end{array}$ & $\begin{array}{r}.0272 \\
.0278 \\
.0298\end{array}$ & $\begin{array}{r}.0016 \\
.0009 \\
.0005\end{array}$ \\
\hline 13.7 & $\begin{array}{l}110 \\
115 \\
120\end{array}$ & $\begin{array}{l}.145 \\
.193 \\
.251\end{array}$ & $\begin{array}{r}.0297 \\
.0297 \\
.0304\end{array}$ & $\begin{array}{l}.0026 \\
.0031 \\
.0031\end{array}$ \\
\hline 20.1 & $\begin{array}{l}110 \\
115 \\
120\end{array}$ & $\begin{array}{l}.111 \\
.153 \\
.206\end{array}$ & $\begin{array}{r}.0388 \\
.0375 \\
.0370\end{array}$ & $\begin{array}{l}.0026 \\
.0026 \\
.0034\end{array}$ \\
\hline 28.0 & $\begin{array}{l}110 \\
115 \\
120\end{array}$ & $\begin{array}{l}.089 \\
.120 \\
.157\end{array}$ & $\begin{array}{r}.0483 \\
.0478 \\
.0489\end{array}$ & $\begin{array}{r}.0029 \\
.0026 \\
.0027\end{array}$ \\
\hline 41.1 & $\begin{array}{l}110 \\
115 \\
120\end{array}$ & $\begin{array}{l}.072 \\
.094 \\
.126\end{array}$ & $\begin{array}{r}.0594 \\
.0608 \\
.0608\end{array}$ & $\begin{array}{r}.0031 \\
.0029 \\
.0028\end{array}$ \\
\hline 49.4 & $\begin{array}{l}110 \\
115 \\
120\end{array}$ & $\begin{array}{l}.062 \\
.080 \\
.108\end{array}$ & $\begin{array}{r}.0699 \\
.0715 \\
.0707\end{array}$ & $\begin{array}{r}.0023 \\
.0022 \\
.0025\end{array}$ \\
\hline 58.2 & $\begin{array}{l}115 \\
120\end{array}$ & $\begin{array}{l}.073 \\
.097\end{array}$ & $\begin{array}{r}.0784 \\
.0793\end{array}$ & $\begin{array}{r}.0018 \\
.0025\end{array}$ \\
\hline 64.6 & $\begin{array}{l}115 \\
120\end{array}$ & $\begin{array}{l}.067 \\
.086\end{array}$ & $\begin{array}{l}.0860 \\
.0890\end{array}$ & $\begin{array}{l}.0009 \\
.0026\end{array}$ \\
\hline 70.1 & $\begin{array}{l}115 \\
120\end{array}$ & $\begin{array}{l}.063 \\
.079\end{array}$ & $\begin{array}{l}.0911 \\
.0965\end{array}$ & $\begin{array}{r}.0011 \\
.0013\end{array}$ \\
\hline 78.6 & $\begin{array}{l}115 \\
120\end{array}$ & $\begin{array}{l}.055 \\
.072\end{array}$ & $\begin{array}{l}.1046 \\
.1058\end{array}$ & $\begin{array}{r}.0018 \\
.0018\end{array}$ \\
\hline
\end{tabular}




\section{APPENDIX D - CLUSTERED ORIFICE DATA}

The two-microphone impedance test data is summarized herein for the twenty clustered orifice resonator configurations described in Table IV. The data is presented in a manner similar to that of Appendix A. 
Model \#1 N=1; $\mathrm{d}^{*}=7.11 \mathrm{~mm} ; \tau *=1.02 \mathrm{~mm} ; \mathrm{D}^{*}=50.80 \mathrm{~mm} ; \mathrm{L} *=38.10 \mathrm{~mm}$

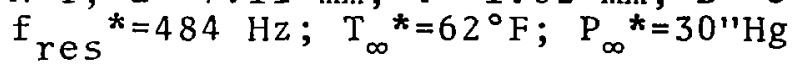

\begin{tabular}{|c|c|c|c|c|}
\hline $\begin{array}{c}V_{\infty}^{*} \\
(\text { meters/sec })\end{array}$ & $\begin{array}{l}P_{i^{*}}^{*} \\
\left(d_{B}\right)\end{array}$ & $\mathrm{C}_{\mathrm{D}}$ & $\mathrm{R}_{\mathrm{o}} * / \rho^{*} \mathrm{C}^{*}$ & $x_{t} * / \rho^{*} c^{*}$ \\
\hline 0 & $\begin{array}{r}70 \\
90 \\
100 \\
110 \\
120 \\
130 \\
135 \\
140\end{array}$ & $\begin{array}{l}.219 \\
.575 \\
.770 \\
.768 \\
.672 \\
.650 \\
.630 \\
.605\end{array}$ & $\begin{array}{r}.0020 \\
.0024 \\
.0032 \\
.0057 \\
.0113 \\
.0182 \\
.0256 \\
.0363\end{array}$ & $\begin{array}{c}0 \\
-.000 \\
+.0001 \\
-.0006 \\
-.0032 \\
-.0116 \\
-.0155 \\
-.0204\end{array}$ \\
\hline 20.1 & $\begin{array}{l}120 \\
130 \\
135 \\
140\end{array}$ & $\begin{array}{l}.293 \\
.457 \\
.522 \\
.577\end{array}$ & $\begin{array}{l}.0166 \\
.0251 \\
.0316 \\
.0400\end{array}$ & $\begin{array}{l}-.0217 \\
-.0182 \\
-.0178 \\
-.0174\end{array}$ \\
\hline 28.7 & $\begin{array}{l}120 \\
130 \\
135 \\
140\end{array}$ & $\begin{array}{l}.202 \\
.336 \\
.434 \\
.491\end{array}$ & $\begin{array}{l}.0293 \\
.0347 \\
.0382 \\
.0468\end{array}$ & $\begin{array}{l}-.0264 \\
-.0238 \\
-.0208 \\
-.0209\end{array}$ \\
\hline 40.5 & $\begin{array}{l}120 \\
130 \\
135 \\
140\end{array}$ & $\begin{array}{l}.142 \\
.250 \\
.314 \\
.404\end{array}$ & $\begin{array}{l}.0479 \\
.0493 \\
.0541 \\
.0575\end{array}$ & $\begin{array}{l}-.0293 \\
-.0278 \\
-.0261 \\
-.0239\end{array}$ \\
\hline 57.0 & $\begin{array}{l}120 \\
130 \\
135 \\
140\end{array}$ & $\begin{array}{l}.101 \\
.168 \\
.241 \\
.298\end{array}$ & $\begin{array}{r}.0717 \\
.0764 \\
.0720 \\
.0795\end{array}$ & $\begin{array}{l}-.0323 \\
-.0359 \\
-.0311 \\
-.0286\end{array}$ \\
\hline 69.8 & $\begin{array}{l}120 \\
130 \\
135 \\
140\end{array}$ & $\begin{array}{l}.077 \\
.139 \\
.185 \\
.241\end{array}$ & $\begin{array}{r}.0973 \\
.0956 \\
.0958 \\
.0984\end{array}$ & $\begin{array}{l}-.0367 \\
-.0355 \\
-.0348 \\
-.0349\end{array}$ \\
\hline 78.6 & $\begin{array}{l}120 \\
130 \\
135 \\
140\end{array}$ & $\begin{array}{l}.069 \\
.117 \\
.163 \\
.210\end{array}$ & $\begin{array}{r}.1090 \\
.1145 \\
.1101 \\
.1137\end{array}$ & $\begin{array}{l}-.0386 \\
-.0376 \\
-.0368 \\
-.0375\end{array}$ \\
\hline
\end{tabular}




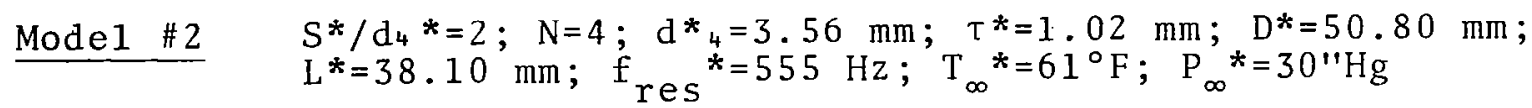

\begin{tabular}{|c|c|c|c|c|}
\hline $\begin{array}{c}\mathrm{V}_{\infty} * \\
(\mathrm{~meters} / \mathrm{sec})\end{array}$ & $\begin{array}{l}\mathrm{P}_{\mathbf{i}} * \\
(\mathrm{~dB})\end{array}$ & $\mathrm{C}_{\mathrm{D}}$ & $\mathrm{R}_{\mathrm{o}} * / \rho * \mathrm{c} *$ & $x_{t} * / \rho * c *$ \\
\hline 0 & $\begin{array}{r}70 \\
80 \\
90 \\
100 \\
110 \\
120 \\
130 \\
135 \\
140\end{array}$ & $\begin{array}{l}.184 \\
.319 \\
.514 \\
.674 \\
.731 \\
.686 \\
.654 \\
.636 \\
.621\end{array}$ & $\begin{array}{l}.0025 \\
.0025 \\
.0028 \\
.0038 \\
.0062 \\
.0113 \\
.0194 \\
.0268 \\
.0378\end{array}$ & $\begin{array}{c}0 \\
0 \\
-.0001 \\
0 \\
-.0003 \\
-.0034 \\
-.0104 \\
-.0139 \\
-.0163\end{array}$ \\
\hline 20.4 & $\begin{array}{l}120 \\
130 \\
135 \\
140\end{array}$ & $\begin{array}{l}.341 \\
.466 \\
.508 \\
.557\end{array}$ & $\begin{array}{l}.0180 \\
.0266 \\
.0340 \\
.0429\end{array}$ & $\begin{array}{l}-.0148 \\
-.0156 \\
-.0163 \\
-.0161\end{array}$ \\
\hline 28.7 & $\begin{array}{l}120 \\
130 \\
135 \\
140\end{array}$ & $\begin{array}{l}.228 \\
.382 \\
.444 \\
.504\end{array}$ & $\begin{array}{r}.0305 \\
.0332 \\
.0393 \\
.0474\end{array}$ & $\begin{array}{l}-.0181 \\
-.0175 \\
-.0178 \\
-.0177\end{array}$ \\
\hline 40.5 & $\begin{array}{l}120 \\
130 \\
135 \\
140\end{array}$ & $\begin{array}{l}.156 \\
.280 \\
.358 \\
.433\end{array}$ & $\begin{array}{r}.0470 \\
.0469 \\
.0495 \\
.0556\end{array}$ & $\begin{array}{l}-.0216 \\
-.0209 \\
-.0202 \\
-.0198\end{array}$ \\
\hline 57.0 & $\begin{array}{l}120 \\
130 \\
135 \\
140\end{array}$ & $\begin{array}{l}.113 \\
.200 \\
.260 \\
.327\end{array}$ & $\begin{array}{r}.0675 \\
.0673 \\
.0693 \\
.0743\end{array}$ & $\begin{array}{l}-.0241 \\
-.0246 \\
-.0248 \\
-.0242\end{array}$ \\
\hline 69.8 & $\begin{array}{l}120 \\
130 \\
135 \\
140\end{array}$ & $\begin{array}{l}.092 \\
.163 \\
.209 \\
.281\end{array}$ & $\begin{array}{r}.0839 \\
.0844 \\
.0880 \\
.0870\end{array}$ & $\begin{array}{l}-.0269 \\
-.0247 \\
-.0261 \\
-.0261\end{array}$ \\
\hline 78.3 & $\begin{array}{l}120 \\
130 \\
135 \\
140\end{array}$ & $\begin{array}{l}.075 \\
.137 \\
.181 \\
.222\end{array}$ & $\begin{array}{r}.1035 \\
.1004 \\
.1019 \\
.1106\end{array}$ & $\begin{array}{l}-.0296 \\
-.0285 \\
-.0282 \\
-.0314\end{array}$ \\
\hline
\end{tabular}


Mode1 \#3 $\quad \mathrm{S}^{*} / \mathrm{d}^{*}=3 ; \mathrm{N}=4 ; \mathrm{d}_{4}^{*}=3.56 \mathrm{~mm} ; \tau^{*}=1.02 \mathrm{~mm} ; \mathrm{D}^{*}=50.80 \mathrm{~mm} ;$ $\mathrm{L}^{*}=38.10 \mathrm{~mm} ; \mathrm{f}_{\text {res }}{ }^{*}=594 \mathrm{~Hz} ; \mathrm{T}_{\infty}^{*}=66^{\circ} \mathrm{F} ; \mathrm{P}_{\infty}^{*}=30^{\prime \prime} \mathrm{Hg}$

\begin{tabular}{|c|c|c|c|c|}
\hline $\begin{array}{c}V_{\infty}^{*} \\
(\operatorname{meters} / \text { sec })\end{array}$ & $\begin{array}{l}\mathrm{P}_{i}^{*} \\
(\mathrm{~dB})\end{array}$ & ${ }^{C} \mathrm{D}$ & $\mathrm{R}_{\mathrm{o}}{ }^{*} / \rho^{*} \mathrm{C}^{*}$ & $X_{t}{ }^{*} / \rho^{*} c^{*}$ \\
\hline 0 & $\begin{array}{r}70 \\
80 \\
90 \\
100 \\
110 \\
115 \\
120 \\
130 \\
135 \\
140\end{array}$ & $\begin{array}{l}.185 \\
.323 \\
.518 \\
.676 \\
.736 \\
.723 \\
.696 \\
.682 \\
.653 \\
.619\end{array}$ & $\begin{array}{l}.0025 \\
.0026 \\
.0028 \\
.0039 \\
.0063 \\
.0085 \\
.0112 \\
.0178 \\
.0259 \\
.0383\end{array}$ & $\begin{array}{c}0 \\
0 \\
0 \\
0 \\
-.0001 \\
-.0011 \\
-.0038 \\
-.0120 \\
-.0150 \\
-.0173\end{array}$ \\
\hline 20.3 & $\begin{array}{l}120 \\
130 \\
135 \\
140\end{array}$ & $\begin{array}{l}.370 \\
.494 \\
.541 \\
.577\end{array}$ & $\begin{array}{r}.0178 \\
.0260 \\
.0330 \\
.0128\end{array}$ & $\begin{array}{l}-.0136 \\
-.0148 \\
-.0152 \\
-.0152\end{array}$ \\
\hline 28.7 & $\begin{array}{l}120 \\
130 \\
135 \\
140\end{array}$ & $\begin{array}{l}.248 \\
.404 \\
.470 \\
.516\end{array}$ & $\begin{array}{r}.0286 \\
.0326 \\
.0385 \\
.0480\end{array}$ & $\begin{array}{l}-.0175 \\
-.0168 \\
-.0164 \\
-.0165\end{array}$ \\
\hline 40.5 & $\begin{array}{l}120 \\
130 \\
135 \\
140\end{array}$ & $\begin{array}{l}.166 \\
.298 \\
.378 \\
.450\end{array}$ & $\begin{array}{r}.0454 \\
.0454 \\
.0487 \\
.0554\end{array}$ & $\begin{array}{l}-.0212 \\
-.0198 \\
-.0186 \\
-.0180\end{array}$ \\
\hline 57.4 & $\begin{array}{l}120 \\
130 \\
135 \\
140\end{array}$ & $\begin{array}{l}.122 \\
.213 \\
.275 \\
.363\end{array}$ & $\begin{array}{l}.0642 \\
.0653 \\
.0678 \\
.0694\end{array}$ & $\begin{array}{l}-.0217 \\
-.0233 \\
-.0225 \\
-.0205\end{array}$ \\
\hline 78.4 & $\begin{array}{l}120 \\
130 \\
135 \\
140\end{array}$ & $\begin{array}{l}.084 \\
.159 \\
.202 \\
.265\end{array}$ & $\begin{array}{l}.0956 \\
.0941 \\
.0941 \\
.0957\end{array}$ & $\begin{array}{l}-.0259 \\
-.0255 \\
-.0244 \\
-.0247\end{array}$ \\
\hline
\end{tabular}


Model \#4 $\mathrm{S}^{*} / \mathrm{d}_{4}=2 ; \mathrm{N}=4 ; \mathrm{d}_{4} *=3.56 \mathrm{~mm} ; \tau^{*}=1.02 \mathrm{~mm} ; \mathrm{D}^{*}=50.80 \mathrm{~mm}$; $\mathrm{L}^{*}=38.10 \mathrm{~mm} ; \mathrm{f}_{\text {res }}^{*}=553 ; \mathrm{T}_{\infty}^{*}=61^{\circ} \mathrm{F} ; \mathrm{P}_{\infty}^{*}=30^{\prime \prime} \mathrm{Hg}$

\begin{tabular}{|c|c|c|c|c|}
\hline$\frac{V_{\infty}^{*}}{(\operatorname{meters} / \sec )}$ & $\begin{array}{l}P_{i}^{*} \\
\left(d_{B}\right)\end{array}$ & $\mathrm{C}_{\mathrm{D}}$ & $R_{0} * / \rho^{*} c^{*}$ & $x_{t} * / \rho^{\star} c^{*}$ \\
\hline 0 & $\begin{array}{r}70 \\
80 \\
90 \\
100 \\
110 \\
120 \\
130 \\
135 \\
140\end{array}$ & $\begin{array}{l}.187 \\
.324 \\
.521 \\
.679 \\
.733 \\
.693 \\
.657 \\
.639 \\
.622\end{array}$ & $\begin{array}{l}.0024 \\
.0025 \\
.0028 \\
.0038 \\
.0062 \\
.0112 \\
.0193 \\
.0267 \\
.0380\end{array}$ & $\begin{array}{c}0 \\
0 \\
0 \\
0 \\
-.0004 \\
-.0034 \\
-.0106 \\
-.0140 \\
-.0163\end{array}$ \\
\hline 20.7 & $\begin{array}{l}120 \\
130 \\
135 \\
140\end{array}$ & $\begin{array}{l}.418 \\
.549 \\
.577 \\
.589\end{array}$ & $\begin{array}{l}.0173 \\
.0240 \\
.0314 \\
.0413\end{array}$ & $\begin{array}{l}-.0089 \\
-.0093 \\
-.0111 \\
-.0139\end{array}$ \\
\hline 28.7 & $\begin{array}{l}120 \\
130 \\
135 \\
140\end{array}$ & $\begin{array}{l}.305 \\
.477 \\
.528 \\
.564\end{array}$ & $\begin{array}{l}.0245 \\
.0288 \\
.0348 \\
.0435\end{array}$ & $\begin{array}{l}-.0103 \\
-.0094 \\
-.0108 \\
-.0132\end{array}$ \\
\hline 40.2 & $\begin{array}{l}120 \\
130 \\
135 \\
140\end{array}$ & $\begin{array}{l}.208 \\
.359 \\
.442 \\
.494\end{array}$ & $\begin{array}{l}.0361 \\
.0387 \\
.0417 \\
.0503\end{array}$ & $\begin{array}{l}-.0149 \\
-.0107 \\
-.0095 \\
-.0127\end{array}$ \\
\hline 57.0 & $\begin{array}{l}120 \\
130 \\
135 \\
140\end{array}$ & $\begin{array}{l}.147 \\
.261 \\
.331 \\
.418\end{array}$ & $\begin{array}{l}.0518 \\
.0535 \\
.0571 \\
.0606\end{array}$ & $\begin{array}{l}-.0188 \\
-.0144 \\
-.0110 \\
-.0100\end{array}$ \\
\hline 69.5 & $\begin{array}{l}120 \\
130 \\
135 \\
140\end{array}$ & $\begin{array}{l}.114 \\
.211 \\
.285 \\
.349\end{array}$ & $\begin{array}{l}.0671 \\
.0657 \\
.0659 \\
.0726\end{array}$ & $\begin{array}{l}-.0232 \\
-.0195 \\
-.0147 \\
-.0115\end{array}$ \\
\hline 78.6 & $\begin{array}{l}120 \\
130 \\
135 \\
140\end{array}$ & $\begin{array}{l}.097 \\
.184 \\
.251 \\
.327\end{array}$ & $\begin{array}{r}.0795 \\
.0751 \\
.0747 \\
.0775\end{array}$ & $\begin{array}{l}-.0253 \\
-.0221 \\
-.0168 \\
-.0127\end{array}$ \\
\hline
\end{tabular}


Mode1 \# $5 \quad \mathrm{~S}^{*} / \mathrm{d}_{4}^{*}=3 ; \mathrm{N}=4 ; \mathrm{d}_{4}^{*}=3.56 \mathrm{~mm} ; \tau^{*}=1.02 \mathrm{~mm} ; \mathrm{D}^{*}=50.80 \mathrm{~mm}$; $\mathrm{L}^{*}=38.10 \mathrm{~mm} ; \mathrm{f}_{\mathrm{res}}^{*}=592 \mathrm{~Hz} ; \mathrm{T}_{\infty}^{*}=62^{\circ} \mathrm{F} ; \mathrm{P}_{\infty}^{*}=30^{\prime \prime \mathrm{Hg}}$

\begin{tabular}{|c|c|c|c|c|}
\hline $\begin{array}{c}\mathrm{V}_{\infty}{ }^{*} \\
(\text { meters/sec })\end{array}$ & $\mathrm{P}_{\dot{i}^{*}}^{*}$ & $\mathrm{C}_{\mathrm{D}}$ & $\mathrm{R}_{\mathrm{o}}{ }^{*} / \rho^{*} \mathrm{c}^{*}$ & $X_{t}{ }^{*} / \rho^{*} c^{*}$ \\
\hline 0 & $\begin{array}{r}70 \\
80 \\
90 \\
100 \\
110 \\
115 \\
120 \\
125 \\
130 \\
135 \\
140\end{array}$ & $\begin{array}{l}.185 \\
.320 \\
.510 \\
.670 \\
.728 \\
.716 \\
.694 \\
.682 \\
.674 \\
.643 \\
.615\end{array}$ & $\begin{array}{l}.0025 \\
.0026 \\
.0029 \\
.0039 \\
.0064 \\
.0086 \\
.0113 \\
.0135 \\
.0181 \\
.0264 \\
.0387\end{array}$ & $\begin{array}{c}0 \\
0 \\
0 \\
0 \\
0 \\
-.0010 \\
-.0036 \\
-.0088 \\
-.0121 \\
-.0151 \\
-.0174\end{array}$ \\
\hline 20.3 & $\begin{array}{l}120 \\
125 \\
130 \\
135 \\
140\end{array}$ & $\begin{array}{l}.348 \\
.417 \\
.496 \\
.523 \\
.569\end{array}$ & $\begin{array}{r}.0179 \\
.0216 \\
.0255 \\
.0337 \\
.0432\end{array}$ & $\begin{array}{l}-.0156 \\
-.0151 \\
-.0150 \\
-.0164 \\
-.0150\end{array}$ \\
\hline 28.7 & $\begin{array}{l}120 \\
125 \\
130 \\
135 \\
140\end{array}$ & $\begin{array}{l}.244 \\
.315 \\
.404 \\
.472 \\
.517\end{array}$ & $\begin{array}{r}.0281 \\
.0297 \\
.0320 \\
.0377 \\
.0474\end{array}$ & $\begin{array}{l}-.0188 \\
-.0185 \\
-.0170 \\
-.0171 \\
-.0172\end{array}$ \\
\hline 41.6 & $\begin{array}{l}120 \\
125 \\
130 \\
135 \\
140\end{array}$ & $\begin{array}{l}.170 \\
.228 \\
.285 \\
.366 \\
.453\end{array}$ & $\begin{array}{r}.0437 \\
.0435 \\
.0468 \\
.0497 \\
.0546\end{array}$ & $\begin{array}{l}-.0210 \\
-.0210 \\
-.0214 \\
-.0195 \\
-.0181\end{array}$ \\
\hline 57.4 & $\begin{array}{l}120 \\
125 \\
130 \\
135 \\
140\end{array}$ & $\begin{array}{r}.123 \\
.162 \\
.215 \\
.279 \\
.349\end{array}$ & $\begin{array}{r}.0629 \\
.0638 \\
.0644 \\
.0667 \\
.0720\end{array}$ & $\begin{array}{l}-.0226 \\
-.0228 \\
-.0222 \\
-.0216 \\
-.0199\end{array}$ \\
\hline 78.3 & $\begin{array}{l}120 \\
125 \\
130 \\
135 \\
140\end{array}$ & $\begin{array}{r}.091 \\
.116 \\
.153 \\
.205 \\
.262\end{array}$ & $\begin{array}{r}.0875 \\
.0921 \\
.0927 \\
.0926 \\
.0970\end{array}$ & $\begin{array}{l}-.0236 \\
-.0233 \\
-.0239 \\
-.0225 \\
-.0221\end{array}$ \\
\hline
\end{tabular}


Mode1 \#6 $\mathrm{S} / \mathrm{d}_{4}=2.5 ; \mathrm{N}=4 ; \mathrm{d}_{4}^{*}=3.56 \mathrm{~mm} ; \tau^{*}=1.02 \mathrm{~mm} ; \mathrm{D}^{*}=50.30 \mathrm{~mm}$; $\mathrm{L}^{*}=38.10 \mathrm{~mm} ; \mathrm{f}_{\text {res }}^{*}=563 \mathrm{~Hz} ; \mathrm{T}_{\infty}^{*}=66^{\circ} \mathrm{F} ; \mathrm{P}_{\infty}^{*}=29.9^{\prime \prime} \mathrm{Hg}$

\begin{tabular}{|c|c|c|c|c|}
\hline $\begin{array}{c}\mathrm{V}_{\infty}^{*} \\
(\text { meters } / \mathrm{sec})\end{array}$ & $P_{i}^{*}{ }_{(d B)}$ & $\mathrm{C}_{\mathrm{D}}$ & $\mathrm{R}_{\mathrm{o}}^{*} / \rho^{*} \mathrm{c}^{*}$ & $X_{t}{ }^{*} / \rho^{*} c^{*}$ \\
\hline 0 & $\begin{array}{r}70 \\
80 \\
90 \\
100 \\
110 \\
120 \\
125 \\
130 \\
135 \\
140\end{array}$ & $\begin{array}{l}.186 \\
.323 \\
.518 \\
.683 \\
.732 \\
.723 \\
.683 \\
.660 \\
.660 \\
.645\end{array}$ & $\begin{array}{l}.0025 \\
.0025 \\
.0028 \\
.0038 \\
.0063 \\
.0109 \\
.0147 \\
.0198 \\
.0265 \\
.0372\end{array}$ & $\begin{array}{c}0 \\
0 \\
0 \\
0 \\
-.0002 \\
-.0035 \\
-.0062 \\
-.0097 \\
-.0128 \\
-.0150\end{array}$ \\
\hline 60.6 & $\begin{array}{l}120 \\
125 \\
130 \\
135 \\
140\end{array}$ & $\begin{array}{l}.113 \\
.155 \\
.202 \\
.281 \\
.363\end{array}$ & $\begin{array}{l}.0688 \\
.0671 \\
.0688 \\
.0661 \\
.0696\end{array}$ & $\begin{array}{l}-.0221 \\
-.0219 \\
-.0218 \\
-.0196 \\
-.0159\end{array}$ \\
\hline
\end{tabular}

Mode1 \#7 $\quad \mathrm{S} / \mathrm{d}_{16}=1.5 ; \mathrm{N}=16 ; \mathrm{d}_{16}^{*}=1.78 \mathrm{~mm} ; \mathrm{\tau}^{*}=1.02 \mathrm{~mm} ; \mathrm{D}^{*}=5.08 \mathrm{~mm}$; $\mathrm{L}^{*}=38.10 \mathrm{~mm} ; \mathrm{f}_{\text {res }}^{*}=564 \mathrm{~Hz} ; \mathrm{T}_{\infty}^{*}=61^{\circ} \mathrm{F} ; \mathrm{P}_{\infty}^{*}=30^{\prime \prime} \mathrm{Hg}$

\begin{tabular}{|c|c|c|c|c|}
\hline $\begin{array}{c}V_{\infty}^{*} \\
(\text { meters } / \text { sec })\end{array}$ & $\begin{array}{l}P_{i}^{*} \\
(\bar{d} B)\end{array}$ & $\mathrm{C}_{\mathrm{D}}$ & $\mathrm{R}_{\mathrm{o}}^{*} / \rho^{*} \mathrm{c}^{*}$ & $X_{t} * / \rho * c *$ \\
\hline 0 & $\begin{array}{r}70 \\
80 \\
90 \\
100 \\
110 \\
115 \\
120 \\
125 \\
130 \\
135\end{array}$ & $\begin{array}{l}.135 \\
.240 \\
.398 \\
.531 \\
.616 \\
.638 \\
.629 \\
.601 \\
.581 \\
.587\end{array}$ & $\begin{array}{r}.0034 \\
.0034 \\
.0037 \\
.0049 \\
.0074 \\
.0094 \\
.0126 \\
.0175 \\
.0242 \\
.0322\end{array}$ & $\begin{array}{c}0 \\
0 \\
-.0001 \\
-.0003 \\
-.0011 \\
-.0023 \\
-.0038 \\
-.0057 \\
-.0080 \\
-.0093\end{array}$ \\
\hline
\end{tabular}




\begin{tabular}{|c|c|c|c|c|}
\hline 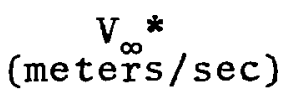 & $\mathrm{P}_{\dot{\mathrm{d}}_{\mathrm{d}}}^{*}$ & $C_{D}$ & $\mathrm{R}_{0}^{*} / \rho^{\star} \mathrm{C}^{\star}$ & $X_{t}{ }^{*} / \rho^{*} c^{*}$ \\
\hline 7.6 & $\begin{array}{l}115 \\
120 \\
125 \\
130 \\
135\end{array}$ & $\begin{array}{l}.644 \\
.637 \\
.622 \\
.608 \\
.608\end{array}$ & $\begin{array}{r}.0094 \\
.0125 \\
.0171 \\
.0234 \\
.0314\end{array}$ & $\begin{array}{l}-.0025 \\
-.0039 \\
-.0051 \\
-.0066 \\
-.0082\end{array}$ \\
\hline 13.7 & $\begin{array}{l}115 \\
120 \\
125 \\
130 \\
135\end{array}$ & $\begin{array}{l}.615 \\
.587 \\
.601 \\
.594 \\
.601\end{array}$ & $\begin{array}{l}.0093 \\
.0129 \\
.0170 \\
.0231 \\
.0309\end{array}$ & $\begin{array}{l}-.0044 \\
-.0058 \\
-.0072 \\
-.0091 \\
-.0110\end{array}$ \\
\hline 20.4 & $\begin{array}{l}115 \\
120 \\
125 \\
130 \\
135\end{array}$ & $\begin{array}{l}.461 \\
.494 \\
.530 \\
.523 \\
.561\end{array}$ & $\begin{array}{r}.0114 \\
.0144 \\
.0182 \\
.0262 \\
.0334\end{array}$ & $\begin{array}{l}-.0072 \\
-.0087 \\
-.0103 \\
-.0106 \\
-.0108\end{array}$ \\
\hline 29.0 & $\begin{array}{l}115 \\
120 \\
125 \\
130 \\
135\end{array}$ & $\begin{array}{l}.251 \\
.312 \\
.318 \\
.446 \\
.500\end{array}$ & $\begin{array}{l}.0192 \\
.0223 \\
.0252 \\
.0301 \\
.0369\end{array}$ & $\begin{array}{l}-.0158 \\
-.0145 \\
-.0134 \\
-.0140 \\
-.0138\end{array}$ \\
\hline 41.5 & $\begin{array}{l}115 \\
120 \\
125 \\
130 \\
135\end{array}$ & $\begin{array}{l}.160 \\
.206 \\
.272 \\
.430 \\
.411\end{array}$ & $\begin{array}{r}.0328 \\
.0348 \\
.0359 \\
.0415 \\
.0448\end{array}$ & $\begin{array}{l}-.0210 \\
-.0205 \\
-.0193 \\
-.0193 \\
-.0172\end{array}$ \\
\hline 58.2 & $\begin{array}{l}115 \\
120 \\
125 \\
130 \\
135\end{array}$ & $\begin{array}{l}.102 \\
.143 \\
.186 \\
.239 \\
.312\end{array}$ & $\begin{array}{r}.0550 \\
.0525 \\
.0544 \\
.0569 \\
.0590\end{array}$ & $\begin{array}{l}-.0266 \\
-.0253 \\
-.0244 \\
-.0241 \\
-.0227\end{array}$ \\
\hline 70.7 & $\begin{array}{l}115 \\
120 \\
125 \\
130 \\
135\end{array}$ & $\begin{array}{l}.090 \\
.116 \\
.154 \\
.194 \\
.248\end{array}$ & $\begin{array}{l}.0638 \\
.0662 \\
.0665 \\
.0710 \\
.0751\end{array}$ & $\begin{array}{l}-.0270 \\
-.0275 \\
-.0268 \\
-.0271 \\
-.0262\end{array}$ \\
\hline 79.6 & $\begin{array}{l}115 \\
120 \\
125 \\
130 \\
135\end{array}$ & $\begin{array}{l}.077 \\
.092 \\
.133 \\
.167 \\
.234\end{array}$ & $\begin{array}{r}.0762 \\
.0848 \\
.0783 \\
.0835 \\
.0800\end{array}$ & $\begin{array}{l}-.0288 \\
-.0311 \\
-.0284 \\
-.0286 \\
-.0265\end{array}$ \\
\hline
\end{tabular}


Mode1 \# $8 \quad \mathrm{~S}^{*} / \mathrm{d}^{*}=2.5 ; \mathrm{N}=16 ; \mathrm{d}^{*}=1.78 \mathrm{~mm} ; \tau^{*}=1.02 \mathrm{~mm} ; \mathrm{D}^{*}=50.80 \mathrm{~mm}$; $\mathrm{L}^{*}=38.10 \mathrm{~mm} ; \mathrm{f}_{\text {res }}{ }^{*}=628 \mathrm{~Hz} ; \mathrm{T}_{\infty}^{*}=68^{\circ} \mathrm{F} ; \mathrm{P}_{\infty}^{*}=29.9^{\prime \prime} \mathrm{Hg}$

\begin{tabular}{|c|c|c|c|c|}
\hline$\frac{\mathrm{V}_{\infty}^{*}}{(\mathrm{mete} r \mathrm{~s} / \mathrm{sec})}$ & $\mathrm{P}_{\dot{i}^{*}}^{*}$ & $\mathrm{C}_{\mathrm{D}}$ & $\mathrm{R}_{\mathrm{o}}^{*} / \rho^{*} \mathrm{c}^{*}$ & $x_{t} * / \rho^{*} c^{*}$ \\
\hline 0 & $\begin{array}{r}70 \\
80 \\
90 \\
100 \\
110 \\
115 \\
120 \\
125 \\
130 \\
135 \\
140\end{array}$ & $\begin{array}{l}.146 \\
.260 \\
.437 \\
.624 \\
.701 \\
.742 \\
.768 \\
.748 \\
.731 \\
.706 \\
.690\end{array}$ & $\begin{array}{l}.0032 \\
.0032 \\
.0034 \\
.0042 \\
.0066 \\
.0081 \\
.0101 \\
.0139 \\
.0190 \\
.0269 \\
.0374\end{array}$ & $\begin{array}{c}0 \\
-.0001 \\
-.0001 \\
-.0003 \\
-.0014 \\
-.0024 \\
-.0042 \\
-.0061 \\
-.0080 \\
-.0095 \\
-.0107\end{array}$ \\
\hline 7.9 & $\begin{array}{l}120 \\
125 \\
130 \\
135 \\
140\end{array}$ & $\begin{array}{r}.757 \\
.739 \\
.714 \\
.698 \\
.698\end{array}$ & $\begin{array}{l}.0103 \\
.0141 \\
.0196 \\
.0272 \\
.0370\end{array}$ & $\begin{array}{l}-.0043 \\
-.0060 \\
-.0079 \\
-.0094 \\
-.0103\end{array}$ \\
\hline 13.7 & $\begin{array}{l}120 \\
125 \\
130 \\
135 \\
140\end{array}$ & $\begin{array}{r}.690 \\
.682 \\
.682 \\
.682 \\
.682\end{array}$ & $\begin{array}{r}.0110 \\
.0150 \\
.0204 \\
.0278 \\
.0379\end{array}$ & $\begin{array}{l}-.0055 \\
-.0070 \\
-.0085 \\
-.0100 \\
-.0107\end{array}$ \\
\hline 21.3 & $\begin{array}{l}120 \\
125 \\
130 \\
135 \\
140\end{array}$ & $\begin{array}{l}.506 \\
.567 \\
.608 \\
.622 \\
.616\end{array}$ & $\begin{array}{r}.0154 \\
.0186 \\
.0233 \\
.0308 \\
.0403\end{array}$ & $\begin{array}{l}-.0067 \\
-.0071 \\
-.0087 \\
-.0100 \\
-.0106\end{array}$ \\
\hline 29.0 & $\begin{array}{l}120 \\
125 \\
130 \\
135 \\
140\end{array}$ & $\begin{array}{r}.350 \\
.435 \\
.506 \\
.561 \\
.601\end{array}$ & $\begin{array}{r}.0227 \\
.0246 \\
.0284 \\
.0345 \\
.0433\end{array}$ & $\begin{array}{l}-.0087 \\
-.0084 \\
-.0090 \\
-.0097 \\
-.0107\end{array}$ \\
\hline 41.1 & $\begin{array}{l}120 \\
125 \\
130 \\
135 \\
140\end{array}$ & $\begin{array}{l}.242 \\
.301 \\
.379 \\
.467 \\
.561\end{array}$ & $\begin{array}{r}.0331 \\
.0358 \\
.0383 \\
.0420 \\
.0469\end{array}$ & $\begin{array}{l}-.0115 \\
-.0114 \\
-.0110 \\
-.0099 \\
-.0096\end{array}$ \\
\hline
\end{tabular}




\begin{tabular}{ccccc}
$\begin{array}{c}V_{\infty}^{*} \\
(m e t e r s / s e c)\end{array}$ & $P_{i}^{*}$ & $C_{D}$ & $R_{0}{ }^{*} / \rho^{*} c^{*}$ & $X_{t}{ }^{*} / \rho^{*} c^{*}$ \\
\hline 58.2 & 120 & .175 & .0463 & -.0142 \\
& 125 & .218 & .0499 & -.0143 \\
& 130 & .284 & .0513 & -.0137 \\
& 135 & .366 & .0538 & -.0113 \\
70.7 & 140 & .456 & .0580 & -.0101 \\
& 120 & .136 & .0601 & -.0168 \\
& 125 & .182 & .0603 & -.0160 \\
& 130 & .234 & .0627 & -.0153 \\
& 135 & .312 & .0632 & -.0132 \\
& 140 & .397 & .0667 & -.0110 \\
\hline
\end{tabular}

$\begin{array}{ll}\text { Mode1 \#9 } & \mathrm{S}^{*} / \mathrm{d}_{16}{ }^{*}=3.5 ; \mathrm{N}=16 ; \mathrm{d}_{16}^{*}=1.78 \mathrm{~mm} ; \quad \mathrm{T}^{*}=1.02 \mathrm{~mm} ; \mathrm{D}^{*}=50.8 \mathrm{~mm} ; \\ \mathrm{L}^{*}=38.10 \mathrm{~mm} ; & \mathrm{f}_{\text {res }}^{*}=684 \mathrm{~Hz} ; \mathrm{T}_{\infty}^{*}=67^{\circ} \mathrm{F} ; \mathrm{P}_{\infty}^{*}=30^{\prime \prime} \mathrm{Hg}\end{array}$

\begin{tabular}{|c|c|c|c|c|}
\hline$\left(\right.$ meters $\mathrm{V}_{\mathrm{\infty}}^{*}$ /sec $)$ & $\stackrel{\mathrm{P}_{i}^{*}}{(\mathrm{~dB})}$ & $\mathrm{C}_{\mathrm{D}}$ & $\mathrm{R}_{\mathrm{O}} * / \rho^{*} \mathrm{C} *$ & $X_{t} * / \rho^{*} c *$ \\
\hline 0 & $\begin{array}{r}70 \\
80 \\
90 \\
100 \\
110 \\
115 \\
120 \\
125 \\
130 \\
135\end{array}$ & $\begin{array}{l}.131 \\
.011 \\
.385 \\
.583 \\
.669 \\
.693 \\
.737 \\
.737 \\
.680 \\
.665\end{array}$ & $\begin{array}{l}.0037 \\
.0037 \\
.0039 \\
.0046 \\
.0069 \\
.0086 \\
.0104 \\
.0132 \\
.0190 \\
.0266\end{array}$ & $\begin{array}{c}0 \\
0 \\
0 \\
-.0004 \\
-.0018 \\
-.0033 \\
-.0055 \\
-.0083 \\
-.0123 \\
-.0157\end{array}$ \\
\hline 7.9 & $\begin{array}{l}120 \\
125 \\
130 \\
135\end{array}$ & $\begin{array}{l}.704 \\
.704 \\
.657 \\
.642\end{array}$ & $\begin{array}{r}.0107 \\
.0138 \\
.0196 \\
.0274\end{array}$ & $\begin{array}{l}-.0061 \\
-.0088 \\
-.0128 \\
-.0164\end{array}$ \\
\hline
\end{tabular}




\begin{tabular}{|c|c|c|c|c|}
\hline 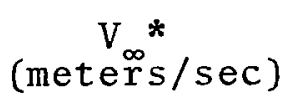 & $\frac{\mathrm{P}_{i}^{*}}{(\mathrm{~dB})}$ & $\mathrm{C}_{\mathrm{D}}$ & $\mathrm{R}_{\mathrm{O}}^{*} / \rho^{*} \mathrm{C}^{*}$ & $X_{t} * / \rho^{*} c^{*}$ \\
\hline 14.0 & $\begin{array}{l}120 \\
125 \\
130 \\
135\end{array}$ & $\begin{array}{l}.635 \\
.657 \\
.627 \\
.635\end{array}$ & $\begin{array}{l}.0109 \\
.0141 \\
.0199 \\
.0274\end{array}$ & $\begin{array}{l}-.0081 \\
-.0104 \\
-.0143 \\
-.0171\end{array}$ \\
\hline 21.3 & $\begin{array}{l}120 \\
125 \\
130 \\
135\end{array}$ & $\begin{array}{l}.444 \\
.493 \\
.546 \\
.559\end{array}$ & $\begin{array}{l}.0150 \\
.0190 \\
.0231 \\
.0311\end{array}$ & $\begin{array}{l}-.0124 \\
-.0137 \\
-.0161 \\
-.0195\end{array}$ \\
\hline 29.3 & $\begin{array}{l}120 \\
125 \\
130 \\
135\end{array}$ & $\begin{array}{l}.293 \\
.365 \\
.439 \\
.493\end{array}$ & $\begin{array}{l}.0224 \\
.0758 \\
.0296 \\
.0360\end{array}$ & $\begin{array}{l}-.0179 \\
-.0182 \\
-.0187 \\
-.0209\end{array}$ \\
\hline 41.1 & $\begin{array}{l}120 \\
125 \\
130 \\
135\end{array}$ & $\begin{array}{l}.205 \\
.262 \\
.333 \\
.400\end{array}$ & $\begin{array}{l}.0357 \\
.0376 \\
.0403 \\
.0459\end{array}$ & $\begin{array}{l}-.0224 \\
-.0230 \\
-.0225 \\
-.0227\end{array}$ \\
\hline 58.2 & $\begin{array}{l}120 \\
125 \\
130 \\
135\end{array}$ & $\begin{array}{l}.151 \\
.198 \\
.244 \\
.307\end{array}$ & $\begin{array}{l}.0511 \\
.0521 \\
.0572 \\
.0616\end{array}$ & $\begin{array}{l}-.0263 \\
-.0257 \\
-.0265 \\
-.0257\end{array}$ \\
\hline 71.0 & $\begin{array}{l}120 \\
125 \\
130 \\
135\end{array}$ & $\begin{array}{l}.121 \\
.159 \\
.201 \\
.265\end{array}$ & $\begin{array}{l}.0648 \\
.0661 \\
.0705 \\
.0721\end{array}$ & $\begin{array}{l}-.0302 \\
-.0293 \\
-.0300 \\
-.0284\end{array}$ \\
\hline 79.6 & $\begin{array}{l}120 \\
125 \\
130 \\
135\end{array}$ & $\begin{array}{l}.105 \\
.128 \\
.181 \\
.241\end{array}$ & $\begin{array}{r}.0753 \\
.0829 \\
.0789 \\
.0795\end{array}$ & $\begin{array}{l}-.0327 \\
-.0350 \\
-.0316 \\
-.0300\end{array}$ \\
\hline
\end{tabular}


Mode1 \#10 $\mathrm{S*} / \mathrm{d}_{16} *=5.0 ; \mathrm{N}=16 ; \mathrm{d}_{16} *=1.78 \mathrm{~mm} ; \tau *=1.02 \mathrm{~mm}$; $\mathrm{D}^{*}=50.80 \mathrm{~mm} ; \mathrm{L}^{*}=38.10 \mathrm{~mm} ; \mathrm{f} \mathrm{Pes}^{*}=709 \mathrm{~Hz} ; \mathrm{T}_{\infty}^{*}=66^{\circ} \mathrm{F} ;$
$\mathrm{P}^{*}=30^{\prime \prime} \mathrm{Hg}$.

\begin{tabular}{|c|c|c|c|c|}
\hline$\frac{V_{\infty}^{*}}{(m e t e r s / s e c)}$ & $\mathrm{P}_{\dot{j}^{*}}^{*}$ & $\mathrm{C}_{\mathrm{D}}$ & $\mathrm{R}_{\mathrm{o}} * / \rho * \mathrm{c} *$ & $x_{t} * / \rho^{*} c^{*}$ \\
\hline 0 & $\begin{array}{r}70 \\
80 \\
90 \\
100 \\
110 \\
120 \\
125 \\
130 \\
135 \\
140\end{array}$ & $\begin{array}{l}.154 \\
.265 \\
.450 \\
.651 \\
.739 \\
.837 \\
.815 \\
.778 \\
.735 \\
.726\end{array}$ & $\begin{array}{r}.0032 \\
.0032 \\
.0034 \\
.0042 \\
.0064 \\
.0098 \\
.0130 \\
.0181 \\
.0261 \\
.0363\end{array}$ & $\begin{array}{c}0 \\
0 \\
0 \\
-.0002 \\
-.0012 \\
-.0038 \\
-.0060 \\
-.0085 \\
-.0107 \\
-.0114\end{array}$ \\
\hline 7.7 & $\begin{array}{l}120 \\
125 \\
130 \\
135 \\
140\end{array}$ & $\begin{array}{l}.806 \\
.778 \\
.752 \\
.726 \\
.710\end{array}$ & $\begin{array}{r}.0100 \\
.0137 \\
.0189 \\
.0266 \\
.0373\end{array}$ & $\begin{array}{l}-.0042 \\
-.0060 \\
-.0084 \\
-.0103 \\
-.0113\end{array}$ \\
\hline 13.7 & $\begin{array}{l}120 \\
125 \\
130 \\
135 \\
140\end{array}$ & $\begin{array}{l}.718 \\
.726 \\
.710 \\
.694 \\
.702\end{array}$ & $\begin{array}{r}.0105 \\
.0141 \\
.0193 \\
.0278 \\
.0377\end{array}$ & $\begin{array}{l}-.0061 \\
-.0077 \\
-.0102 \\
-.0108 \\
-.0114\end{array}$ \\
\hline 21.3 & $\begin{array}{l}120 \\
125 \\
130 \\
135 \\
140\end{array}$ & $\begin{array}{l}.485 \\
.510 \\
.611 \\
.633 \\
.670\end{array}$ & $\begin{array}{r}.0149 \\
.0179 \\
.0227 \\
.0301 \\
.0393\end{array}$ & $\begin{array}{l}-.0101 \\
-.0099 \\
-.0114 \\
-.0128 \\
-.0125\end{array}$ \\
\hline 29.2 & $\begin{array}{l}120 \\
125 \\
130 \\
135 \\
140\end{array}$ & $\begin{array}{l}.348 \\
.408 \\
.520 \\
.564 \\
.633\end{array}$ & $\begin{array}{r}.0216 \\
.0253 \\
.0274 \\
.0342 \\
.0416\end{array}$ & $\begin{array}{l}-.0128 \\
-.0131 \\
-.0120 \\
-.0135 \\
-.0134\end{array}$ \\
\hline 41.2 & $\begin{array}{l}120 \\
125 \\
130 \\
135 \\
140\end{array}$ & $\begin{array}{l}.243 \\
.306 \\
.372 \\
.464 \\
.557\end{array}$ & $\begin{array}{r}.0324 \\
.0348 \\
.0388 \\
.0424 \\
.0474\end{array}$ & $\begin{array}{r}-.0154 \\
-.0155 \\
-.0154 \\
-.0141 \\
-.0145\end{array}$ \\
\hline
\end{tabular}




\begin{tabular}{|c|c|c|c|c|}
\hline $\begin{array}{c}\mathrm{V}_{\infty}^{*} \\
(\text { meters/sec })\end{array}$ & $\mathrm{P}_{\left.\mathrm{d}_{\mathrm{B}}^{*}\right)}^{*}$ & $\mathrm{C}_{\mathrm{D}}$ & $\mathrm{R}_{0} * / \rho^{*} \mathrm{C}^{*}$ & $x_{t} * / \rho^{*} c^{*}$ \\
\hline 58.0 & $\begin{array}{l}120 \\
125 \\
130 \\
135 \\
140\end{array}$ & $\begin{array}{l}.164 \\
.219 \\
.273 \\
.364 \\
.464\end{array}$ & $\begin{array}{r}.0500 \\
.0502 \\
.0540 \\
.0545 \\
.0577\end{array}$ & $\begin{array}{l}-.0178 \\
-.0174 \\
-.0181 \\
-.0165 \\
-.0150\end{array}$ \\
\hline 70.6 & $\begin{array}{l}120 \\
125 \\
130 \\
135 \\
140\end{array}$ & $\begin{array}{l}.132 \\
.180 \\
.232 \\
.292 \\
.386\end{array}$ & $\begin{array}{r}.0632 \\
.0617 \\
.0642 \\
.0684 \\
.0696\end{array}$ & $\begin{array}{l}-.0195 \\
-.0190 \\
-.0188 \\
-.0186 \\
-.0168\end{array}$ \\
\hline 79.7 & $\begin{array}{l}120 \\
125 \\
130 \\
135 \\
140\end{array}$ & $\begin{array}{l}.122 \\
.161 \\
.212 \\
.276 \\
.348\end{array}$ & $\begin{array}{l}.0686 \\
.0697 \\
.0707 \\
.0727 \\
.0774\end{array}$ & $\begin{array}{r}-.0206 \\
-.0200 \\
-.0193 \\
-.0184 \\
-.0181\end{array}$ \\
\hline
\end{tabular}

Mode1 \#11 $\mathrm{S}^{*} / \mathrm{d}_{16} *=6.0 ; \mathrm{N}=16 ; \mathrm{d}_{16} *=1.78 \mathrm{~mm} ; \tau *=1.02 \mathrm{~mm}$;

$\mathrm{D}^{*}=50.80 \mathrm{~mm} ; \mathrm{L}^{*}=38.10 \mathrm{~mm} ; \mathrm{f}_{\text {res }}^{*}=708 \mathrm{~Hz} ; \mathrm{T}_{\infty}^{*}=67^{\circ} \mathrm{F}$
$\mathrm{P}_{\infty}^{*}=30^{\prime \prime} \mathrm{Hg}$

\begin{tabular}{|c|c|c|c|c|}
\hline$\frac{V_{\infty}^{*}}{(\text { meters/sec })}$ & $\begin{array}{l}P_{i} \\
(d B)\end{array}$ & $\mathrm{C}_{\mathrm{D}}$ & $\mathrm{R}_{\mathrm{o}}^{*} / \rho^{*} \mathrm{C} *$ & $x_{t} * / \rho^{*} c^{*}$ \\
\hline 0 & $\begin{array}{r}70 \\
80 \\
90 \\
100 \\
110 \\
115 \\
120 \\
125 \\
130 \\
135 \\
140\end{array}$ & $\begin{array}{l}.123 \\
.223 \\
.375 \\
.548 \\
.622 \\
.659 \\
.679 \\
.679 \\
.637 \\
.615 \\
.594\end{array}$ & $\begin{array}{l}.0040 \\
.0039 \\
.0041 \\
.0050 \\
.0077 \\
.0095 \\
.0116 \\
.0149 \\
.0213 \\
.0304 \\
.0439\end{array}$ & $\begin{array}{c}0 \\
0 \\
0 \\
-.0002 \\
-.0016 \\
-.0029 \\
-.0050 \\
-.0079 \\
-.0118 \\
-.0142 \\
-.0150\end{array}$ \\
\hline
\end{tabular}




\begin{tabular}{|c|c|c|c|c|}
\hline $\begin{array}{c}V_{\infty} * \\
(\text { meters } / \text { sec })\end{array}$ & $\mathrm{P}_{\mathbf{i}}^{*}{ }_{(\mathrm{d} B)}$ & $\mathrm{C}_{\mathrm{D}}$ & $\mathrm{R}_{\mathrm{o}}{ }^{*} / \rho^{*} \mathrm{C} *$ & $X_{t} * / \rho^{*} c^{*}$ \\
\hline 7.9 & $\begin{array}{l}120 \\
125 \\
130 \\
135 \\
140\end{array}$ & $\begin{array}{l}.659 \\
.651 \\
.615 \\
.594 \\
.581\end{array}$ & $\begin{array}{r}.0120 \\
.0159 \\
.0225 \\
.0320 \\
.0453\end{array}$ & $\begin{array}{l}-.0056 \\
-.0081 \\
-.0114 \\
-.0136 \\
-.0141\end{array}$ \\
\hline 13.4 & $\begin{array}{l}120 \\
125 \\
130 \\
135 \\
140\end{array}$ & $\begin{array}{l}.594 \\
.615 \\
.587 \\
.581 \\
.581\end{array}$ & $\begin{array}{r}.0126 \\
.0164 \\
.0232 \\
.0327 \\
.0455\end{array}$ & $\begin{array}{l}-.0075 \\
-.0094 \\
-.0126 \\
-.0141 \\
-.0135\end{array}$ \\
\hline 21.3 & $\begin{array}{l}120 \\
125 \\
130 \\
135 \\
140\end{array}$ & $\begin{array}{l}.411 \\
.477 \\
.517 \\
.523 \\
.548\end{array}$ & $\begin{array}{r}.0178 \\
.0213 \\
.0269 \\
.0365 \\
.0485\end{array}$ & $\begin{array}{l}-.0115 \\
-.0118 \\
-.0132 \\
-.0151 \\
-.0131\end{array}$ \\
\hline 29.3 & $\begin{array}{l}120 \\
125 \\
130 \\
135 \\
140\end{array}$ & $\begin{array}{l}.291 \\
.354 \\
.421 \\
.472 \\
.512\end{array}$ & $\begin{array}{l}.0268 \\
.0300 \\
.0349 \\
.0420 \\
.0527\end{array}$ & $\begin{array}{l}-.0134 \\
-.0133 \\
-.0119 \\
-.0124 \\
-.0109\end{array}$ \\
\hline 41.1 & $\begin{array}{l}120 \\
125 \\
130 \\
135 \\
140\end{array}$ & $\begin{array}{l}.197 \\
.253 \\
.319 \\
.393 \\
.440\end{array}$ & $\begin{array}{r}.0419 \\
.0436 \\
.0470 \\
.0518 \\
.0620\end{array}$ & $\begin{array}{l}-.0143 \\
-.0141 \\
-.0122 \\
-.0092 \\
-.0086\end{array}$ \\
\hline 57.6 & $\begin{array}{l}120 \\
125 \\
130 \\
135 \\
140\end{array}$ & $\begin{array}{l}.135 \\
.181 \\
.223 \\
.298 \\
.366\end{array}$ & $\begin{array}{l}.0632 \\
.0626 \\
.0682 \\
.0688 \\
.0750\end{array}$ & $\begin{array}{l}-.0143 \\
-.0133 \\
-.0128 \\
-.0092 \\
-.0054\end{array}$ \\
\hline 71.0 & $\begin{array}{l}120 \\
125 \\
130 \\
135 \\
140\end{array}$ & $\begin{array}{l}.108 \\
.149 \\
.190 \\
.245 \\
.315\end{array}$ & $\begin{array}{r}.0775 \\
.0751 \\
.0788 \\
.0821 \\
.0857\end{array}$ & $\begin{array}{l}-.0219 \\
-.0206 \\
-.0208 \\
-.0196 \\
-.0168\end{array}$ \\
\hline
\end{tabular}




\begin{tabular}{|c|c|c|c|c|}
\hline $\begin{array}{c}V_{\infty}^{*} \\
(\text { meters } / \mathrm{sec})\end{array}$ & $\mathrm{P}_{j}^{*}{ }_{\mathrm{d} B}^{*}$ & $\mathrm{C}_{\mathrm{D}}$ & $\mathrm{R}_{\mathrm{o}} * / \rho^{*} \mathrm{c}^{*}$ & $x_{t} * / \rho * c *$ \\
\hline 79.2 & $\begin{array}{l}120 \\
125 \\
130 \\
135 \\
140\end{array}$ & $\begin{array}{r}.097 \\
.128 \\
.171 \\
.223 \\
.288\end{array}$ & $\begin{array}{r}.0859 \\
.0871 \\
.0873 \\
.0897 \\
.0937\end{array}$ & $\begin{array}{l}-.0240 \\
-.0244 \\
-.0236 \\
-.0225 \\
-.00199\end{array}$ \\
\hline
\end{tabular}

Mode1 \#12 $\mathrm{S}^{*} / \mathrm{d}_{36} *=1.5 ; \mathrm{N}=36 ; \mathrm{d}_{36} *=1.18 \mathrm{~mm} ; \tau *=1.02 \mathrm{~mm}$

$\mathrm{D}^{*}=50.80 \mathrm{~mm} ; \mathrm{L}^{*}=38.10 \mathrm{~mm} ; \mathrm{f}_{\text {res }}{ }^{*}=563 \mathrm{~Hz} ; \mathrm{T}_{\infty}^{*}=65^{\circ} \mathrm{F} ;$
$\mathrm{P}_{\infty}^{*}=30^{\prime \prime} \mathrm{Hg}$

\begin{tabular}{|c|c|c|c|c|}
\hline$\frac{V_{\infty}^{*}}{(\text { meters/sec })}$ & $\mathrm{P}_{i}^{*}{ }_{(\mathrm{d} B)}$ & $\mathrm{C}_{\mathrm{D}}$ & $\mathrm{R}_{\mathrm{o}}^{*} / \mathrm{p}^{*} \mathrm{C}^{*}$ & $x_{t} * / \rho^{*} c^{*}$ \\
\hline 0 & $\begin{array}{r}70 \\
80 \\
90 \\
100 \\
110 \\
115 \\
120 \\
125 \\
130 \\
135 \\
140\end{array}$ & $\begin{array}{l}.111 \\
.195 \\
.328 \\
.502 \\
.617 \\
.632 \\
.624 \\
.617 \\
.610 \\
.617 \\
.617\end{array}$ & $\begin{array}{l}.0042 \\
.0042 \\
.0044 \\
.0052 \\
.0073 \\
.0095 \\
.0126 \\
.0170 \\
.0231 \\
.0306 \\
.0410\end{array}$ & $\begin{array}{c}0 \\
0 \\
-.0001 \\
-.0004 \\
-.0014 \\
-.0023 \\
-.0036 \\
-.0050 \\
-.0063 \\
-.0075 \\
-.0089\end{array}$ \\
\hline 7.9 & $\begin{array}{l}120 \\
125 \\
130 \\
135 \\
140\end{array}$ & $\begin{array}{l}.624 \\
.632 \\
.632 \\
.632 \\
.624\end{array}$ & $\begin{array}{r}.0127 \\
.0168 \\
.0225 \\
.0301 \\
.0408\end{array}$ & $\begin{array}{l}-.0033 \\
-.0042 \\
-.0052 \\
-.0065 \\
-.0074\end{array}$ \\
\hline 13.6 & $\begin{array}{l}120 \\
125 \\
130 \\
135 \\
140\end{array}$ & $\begin{array}{r}.596 \\
.617 \\
.639 \\
.639 \\
.624\end{array}$ & $\begin{array}{r}.0133 \\
.0172 \\
.0222 \\
.0298 \\
.0409\end{array}$ & $\begin{array}{l}-.0034 \\
-.0044 \\
-.0052 \\
-.0062 \\
-.0070\end{array}$ \\
\hline
\end{tabular}




\begin{tabular}{|c|c|c|c|c|}
\hline $\begin{array}{c}\mathrm{V}_{\infty}^{*} \\
(\mathrm{~meters} / \mathrm{sec})\end{array}$ & $\mathrm{P}_{\left.\mathrm{i}_{\mathrm{d}}^{*}\right)}$ & $\mathrm{C}_{\mathrm{D}}$ & $\mathrm{R}_{\mathrm{o}}{ }^{*} / \rho^{*} \mathrm{C} *$ & $x_{t} * / \rho * c *$ \\
\hline 21.0 & $\begin{array}{l}120 \\
125 \\
130 \\
135 \\
140\end{array}$ & $\begin{array}{l}.531 \\
.569 \\
.583 \\
.617 \\
.632\end{array}$ & $\begin{array}{r}.0143 \\
.0182 \\
.0244 \\
.0307 \\
.0403\end{array}$ & $\begin{array}{l}-.0059 \\
-.0062 \\
-.0056 \\
-.0071 \\
-.0075\end{array}$ \\
\hline 28.7 & $\begin{array}{l}120 \\
125 \\
130 \\
135 \\
140\end{array}$ & $\begin{array}{l}.381 \\
.463 \\
.513 \\
.576 \\
.596\end{array}$ & $\begin{array}{r}.0184 \\
.0217 \\
.0270 \\
.0327 \\
.0427\end{array}$ & $\begin{array}{l}-.0112 \\
-.0094 \\
-.0089 \\
-.0083 \\
-.0084\end{array}$ \\
\hline 40.8 & $\begin{array}{l}120 \\
125 \\
130 \\
135 \\
140\end{array}$ & $\begin{array}{l}.249 \\
.328 \\
.403 \\
.479 \\
.531\end{array}$ & $\begin{array}{r}.0287 \\
.0300 \\
.0338 \\
.0391 \\
.0477\end{array}$ & $\begin{array}{l}-.0162 \\
-.0146 \\
-.0127 \\
-.0110 \\
-.0100\end{array}$ \\
\hline 57.2 & $\begin{array}{l}120 \\
125 \\
130 \\
135 \\
140\end{array}$ & $\begin{array}{l}.168 \\
.222 \\
.289 \\
.368 \\
.463\end{array}$ & $\begin{array}{r}.0477 \\
.0457 \\
.0474 \\
.0506 \\
.0546\end{array}$ & $\begin{array}{l}-.0196 \\
-.0186 \\
-.0174 \\
-.0154 \\
-.0123\end{array}$ \\
\hline 69.7 & $\begin{array}{l}120 \\
125 \\
130 \\
135 \\
140\end{array}$ & $\begin{array}{l}.138 \\
.184 \\
.260 \\
.324 \\
.398\end{array}$ & $\begin{array}{r}.0557 \\
.0561 \\
.0533 \\
.0576 \\
.0633\end{array}$ & $\begin{array}{l}-.0203 \\
-.0193 \\
-.0173 \\
-.0168 \\
-.0150\end{array}$ \\
\hline 78.3 & $\begin{array}{l}120 \\
125 \\
130 \\
135 \\
140\end{array}$ & $\begin{array}{l}.118 \\
.162 \\
.214 \\
.282 \\
.347\end{array}$ & $\begin{array}{r}.0666 \\
.0643 \\
.0654 \\
.0666 \\
.0727\end{array}$ & $\begin{array}{l}-.0206 \\
-.0199 \\
-.0191 \\
-.0178 \\
-.0169\end{array}$ \\
\hline
\end{tabular}


Model \#13 $S * / \mathrm{d}_{36} *=2 ; \mathrm{N}=36 ; \mathrm{d}_{36} *=1.18 \mathrm{~mm} ; \tau^{*}=1.02 \mathrm{~mm}$; $\mathrm{D}^{*}=50.80 \mathrm{~mm} ; \mathrm{L}^{*}=38.10 \mathrm{~mm} ; \mathrm{f}_{\text {res }}{ }^{*}=644 \mathrm{~Hz} ; \mathrm{T}_{\infty}^{*}=69^{\circ} \mathrm{F}$; $\mathrm{P}_{\infty}^{*} * 30$ "' $\mathrm{Hg}$

\begin{tabular}{|c|c|c|c|c|}
\hline$\frac{V_{\infty}^{*}}{(\text { meters }} \stackrel{\text { sec })}{ }$ & $\begin{array}{l}\mathrm{P}_{i^{*}} \\
(\mathrm{~dB})\end{array}$ & $\mathrm{C}_{\mathrm{D}}$ & $\mathrm{R}_{\mathrm{o}}{ }^{*} / \rho^{*} \mathrm{C}^{*}$ & $X_{t} * / \rho^{*} c^{*}$ \\
\hline 0 & $\begin{array}{r}70 \\
80 \\
90 \\
100 \\
110 \\
115 \\
120 \\
125 \\
130 \\
135 \\
140\end{array}$ & $\begin{array}{l}.103 \\
.178 \\
.309 \\
.484 \\
.616 \\
.653 \\
.668 \\
.668 \\
.645 \\
.638 \\
.623\end{array}$ & $\begin{array}{l}.0046 \\
.0048 \\
.0049 \\
.0055 \\
.0075 \\
.0093 \\
.0121 \\
.0162 \\
.0225 \\
.0305 \\
.0421\end{array}$ & $\begin{array}{c}0 \\
-.0001 \\
-.0001 \\
-.0005 \\
-.0020 \\
-.0030 \\
-.0040 \\
-.0049 \\
-.0067 \\
-.0082 \\
-.0092\end{array}$ \\
\hline 7.6 & $\begin{array}{l}120 \\
125 \\
130 \\
135 \\
140\end{array}$ & $\begin{array}{l}.676 \\
.676 \\
.653 \\
.645 \\
.631\end{array}$ & $\begin{array}{r}.0123 \\
.0161 \\
.0223 \\
.0303 \\
.0418\end{array}$ & $\begin{array}{l}-.0027 \\
-.0047 \\
-.0061 \\
-.0075 \\
-.0085\end{array}$ \\
\hline 13.6 & $\begin{array}{l}120 \\
125 \\
130 \\
135 \\
140\end{array}$ & $\begin{array}{l}.616 \\
.645 \\
.623 \\
.638 \\
.623\end{array}$ & $\begin{array}{r}.0131 \\
.0168 \\
.0233 \\
.0307 \\
.0423\end{array}$ & $\begin{array}{l}-.0044 \\
-.0052 \\
-.0066 \\
-.0075 \\
-.0085\end{array}$ \\
\hline 21.3 & $\begin{array}{l}120 \\
125 \\
130 \\
135 \\
140\end{array}$ & $\begin{array}{l}.501 \\
.562 \\
.515 \\
.595 \\
.602\end{array}$ & $\begin{array}{r}.0163 \\
.0193 \\
.0253 \\
.0329 \\
.0438\end{array}$ & $\begin{array}{l}-.0047 \\
-.0058 \\
-.0070 \\
-.0079 \\
-.0089\end{array}$ \\
\hline 28.8 & $\begin{array}{l}120 \\
125 \\
130 \\
135 \\
140\end{array}$ & $\begin{array}{l}.384 \\
.452 \\
.513 \\
.556 \\
.588\end{array}$ & $\begin{array}{r}.0210 \\
.0240 \\
.0285 \\
.0354 \\
.0448\end{array}$ & $\begin{array}{l}-.0068 \\
-.0072 \\
-.0076 \\
-.0082 \\
-.0090\end{array}$ \\
\hline 40.5 & $\begin{array}{l}120 \\
125 \\
130 \\
135 \\
140\end{array}$ & $\begin{array}{l}.272 \\
.343 \\
.407 \\
.484 \\
.543\end{array}$ & $\begin{array}{r}.0297 \\
.0316 \\
.0359 \\
.0406 \\
.0485\end{array}$ & $\begin{array}{l}-.0098 \\
-.0097 \\
-.0096 \\
-.0093 \\
-.0100\end{array}$ \\
\hline
\end{tabular}




\begin{tabular}{|c|c|c|c|c|}
\hline $\begin{array}{c}V_{\infty}^{*} \\
(\operatorname{meters} / \sec )\end{array}$ & $\mathrm{P}_{\dot{i}^{*}}^{*}$ & $\mathrm{C}_{\mathrm{D}}$ & $\mathrm{R}_{\mathrm{o}}{ }^{*} / \rho^{*} \mathrm{C}^{*}$ & $x_{t} * / \rho * c *$ \\
\hline 57.2 & $\begin{array}{l}120 \\
125 \\
130 \\
135 \\
140\end{array}$ & $\begin{array}{l}.193 \\
.248 \\
.302 \\
.495 \\
.462\end{array}$ & $\begin{array}{r}.0420 \\
.0437 \\
.0482 \\
.0395 \\
.0568\end{array}$ & $\begin{array}{l}-.0136 \\
-.0132 \\
-.0135 \\
-.0098 \\
-.0125\end{array}$ \\
\hline 70.1 & $\begin{array}{l}120 \\
125 \\
130 \\
135 \\
140\end{array}$ & $\begin{array}{l}.146 \\
.193 \\
.251 \\
.323 \\
.402\end{array}$ & $\begin{array}{r}.0536 \\
.0547 \\
.0566 \\
.0592 \\
.0647\end{array}$ & $\begin{array}{l}-.0227 \\
-.0218 \\
-.0207 \\
-.0196 \\
-.0182\end{array}$ \\
\hline 78.5 & $\begin{array}{l}120 \\
125 \\
130 \\
135 \\
140\end{array}$ & $\begin{array}{l}.130 \\
.162 \\
.202 \\
.282 \\
.363\end{array}$ & $\begin{array}{r}.0610 \\
.0055 \\
.0706 \\
.0679 \\
.0709\end{array}$ & $\begin{array}{r}-.0234 \\
-.0245 \\
-.0251 \\
-.0226 \\
-.0215\end{array}$ \\
\hline
\end{tabular}

Model \#14 $\mathrm{S}^{*} / \mathrm{d}_{3}{ }^{*}=2.5 ; \mathrm{N}=36 ; \mathrm{d}^{*}=1.18 \mathrm{~mm} ; \tau^{*}=1.02 \mathrm{~mm} ; \mathrm{D}^{*}=50.8 \mathrm{~mm}$; $\mathrm{L}^{*}=38.1 \mathrm{~mm} ; \mathrm{f}_{\text {res }}^{*}=663 \mathrm{~Hz} ; \mathrm{T}_{\infty}^{*}=66^{\circ} \mathrm{F} ; \mathrm{P}_{\infty}^{*=30^{\prime \prime} \mathrm{Hg}}$

\begin{tabular}{|c|c|c|c|c|}
\hline$\frac{V_{\infty}^{*}}{(\text { meters } / \text { sec })}$ & $\left.\mathrm{P}_{\dot{i}}^{*}{ }^{*}\right)$ & $\mathrm{C}_{\mathrm{n}}$ & $\mathrm{R}_{\mathrm{o}} * / \rho^{*} \mathrm{C} *$ & $X_{t}{ }^{*} / \rho^{*} c^{*}$ \\
\hline 0 & $\begin{array}{r}70 \\
80 \\
90 \\
100 \\
110 \\
120 \\
125 \\
130 \\
135 \\
140\end{array}$ & $\begin{array}{l}.119 \\
.200 \\
.343 \\
.544 \\
.677 \\
.734 \\
.745 \\
.728 \\
.720 \\
.720\end{array}$ & $\begin{array}{l}.0040 \\
.0042 \\
.0044 \\
.0049 \\
.0068 \\
.0109 \\
.0146 \\
.0200 \\
.0271 \\
.0365\end{array}$ & $\begin{array}{c}0 \\
0 \\
0 \\
-.0003 \\
-.0017 \\
-.0039 \\
-.0049 \\
-.0062 \\
-.0081 \\
-.0096\end{array}$ \\
\hline
\end{tabular}




\begin{tabular}{|c|c|c|c|c|}
\hline$($ meters/sec) & $\begin{array}{l}P_{i}^{*} \\
(\mathrm{~dB})\end{array}$ & $\mathrm{C}_{\mathrm{D}}$ & $R_{0}{ }^{*} / \rho^{*} c^{*}$ & $x_{t} * / \rho^{*} c^{*}$ \\
\hline 7.7 & $\begin{array}{l}120 \\
125 \\
130 \\
135 \\
140\end{array}$ & $\begin{array}{l}.737 \\
.737 \\
.737 \\
.720 \\
.712\end{array}$ & $\begin{array}{r}.0109 \\
.0147 \\
.0198 \\
.0272 \\
.0369\end{array}$ & $\begin{array}{l}-.0040 \\
-.0050 \\
-.0062 \\
-.0078 \\
-.0096\end{array}$ \\
\hline 13.5 & $\begin{array}{l}120 \\
125 \\
130 \\
135 \\
140\end{array}$ & $\begin{array}{l}.696 \\
.712 \\
.696 \\
.696 \\
.704\end{array}$ & $\begin{array}{r}.0115 \\
.0151 \\
.0208 \\
.0281 \\
.0374\end{array}$ & $\begin{array}{l}-.0046 \\
-.0055 \\
-.0071 \\
-.0083 \\
-.0096\end{array}$ \\
\hline 21.1 & $\begin{array}{l}120 \\
125 \\
130 \\
135 \\
140\end{array}$ & $\begin{array}{l}.534 \\
.613 \\
.613 \\
.649 \\
.672\end{array}$ & $\begin{array}{l}.0151 \\
.0178 \\
.0237 \\
.0303 \\
.0393\end{array}$ & $\begin{array}{r}-.0056 \\
-.0057 \\
-.0077 \\
-.0083 \\
-.0094\end{array}$ \\
\hline 29.2 & $\begin{array}{l}120 \\
125 \\
130 \\
135 \\
140\end{array}$ & $\begin{array}{l}.374 \\
.460 \\
.540 \\
.579 \\
.627\end{array}$ & $\begin{array}{r}.0218 \\
.0238 \\
.0272 \\
.0342 \\
.0423\end{array}$ & $\begin{array}{l}-.0074 \\
-.0074 \\
-.0078 \\
-.0085 \\
-.0096\end{array}$ \\
\hline 41.1 & $\begin{array}{l}120 \\
125 \\
130 \\
135 \\
140\end{array}$ & $\begin{array}{l}.264 \\
.322 \\
.424 \\
.510 \\
.579\end{array}$ & $\begin{array}{r}.0310 \\
.0342 \\
.0348 \\
.0391 \\
.0461\end{array}$ & $\begin{array}{l}-.0098 \\
-.0099 \\
-.0093 \\
-.0085 \\
-.0090\end{array}$ \\
\hline 58.0 & $\begin{array}{l}120 \\
125 \\
130 \\
135 \\
140\end{array}$ & $\begin{array}{l}.185 \\
.233 \\
.300 \\
.396 \\
.492\end{array}$ & $\begin{array}{r}.0445 \\
.0474 \\
.0493 \\
.0504 \\
.0543\end{array}$ & $\begin{array}{l}-.0133 \\
-.0131 \\
-.0128 \\
-.0107 \\
-.0099\end{array}$ \\
\hline 70.5 & $\begin{array}{l}120 \\
125 \\
130 \\
135 \\
140\end{array}$ & $\begin{array}{l}.144 \\
.194 \\
.247 \\
.337 \\
.429\end{array}$ & $\begin{array}{l}.0575 \\
.0571 \\
.0599 \\
.0592 \\
.0623\end{array}$ & $\begin{array}{l}-.0165 \\
-.0155 \\
-.0155 \\
-.0125 \\
-.0115\end{array}$ \\
\hline 79.1 & $\begin{array}{l}120 \\
125 \\
130 \\
135 \\
140\end{array}$ & $\begin{array}{l}.128 \\
.173 \\
.238 \\
.287 \\
.396\end{array}$ & $\begin{array}{l}.0644 \\
.0641 \\
.0622 \\
.0694 \\
.0674\end{array}$ & $\begin{array}{l}-.0196 \\
-.0172 \\
-.0155 \\
-.0155 \\
-.0130\end{array}$ \\
\hline
\end{tabular}


Mode1 \#15 $\mathrm{S}^{*} / \mathrm{d}_{36}{ }^{*}=3.5 ; \mathrm{N}=36 ; \mathrm{d}^{*}=1.18 \mathrm{~mm} ; \tau^{*}=1.02 \mathrm{~mm} ; \mathrm{D}^{*}=50.8 \mathrm{~mm}$;

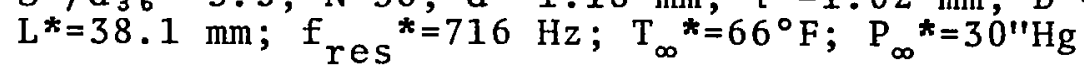

\begin{tabular}{|c|c|c|c|c|}
\hline $\begin{array}{c}V_{\infty}^{*} \\
(\text { moters } / \text { sec })\end{array}$ & $\begin{array}{l}\mathrm{P}_{\mathrm{i}^{*}}^{*} \\
(\mathrm{~dB})\end{array}$ & $\mathrm{C}_{\mathrm{D}}$ & $\mathrm{R}_{\mathrm{o}} * / \rho * \mathrm{c} *$ & $X_{t}^{*} / \rho^{*} c^{*}$ \\
\hline 0 & $\begin{array}{r}70 \\
80 \\
90 \\
100 \\
110 \\
115 \\
120 \\
125 \\
130 \\
135 \\
140\end{array}$ & $\begin{array}{l}.107 \\
.187 \\
.333 \\
.508 \\
.678 \\
.735 \\
.752 \\
.760 \\
.760 \\
.735 \\
.726\end{array}$ & $\begin{array}{l}.0046 \\
.0047 \\
.0047 \\
.0054 \\
.0071 \\
.0084 \\
.0107 \\
.0142 \\
.0193 \\
.0270 \\
.0369\end{array}$ & $\begin{array}{c}0 \\
0 \\
0 \\
-.0002 \\
-.0016 \\
-.0029 \\
-.0045 \\
-.0057 \\
-.0068 \\
-.0084 \\
-.0094\end{array}$ \\
\hline 7.6 & $\begin{array}{l}120 \\
125 \\
130 \\
135 \\
140\end{array}$ & $\begin{array}{l}.743 \\
.752 \\
.743 \\
.735 \\
.735\end{array}$ & $\begin{array}{r}.0108 \\
.0144 \\
.0197 \\
.0269 \\
.0364\end{array}$ & $\begin{array}{r}-.0046 \\
-.0058 \\
-.0070 \\
-.0086 \\
-.0097\end{array}$ \\
\hline 13.7 & $\begin{array}{l}120 \\
125 \\
130 \\
135 \\
140\end{array}$ & $\begin{array}{l}.686 \\
.710 \\
.710 \\
.718 \\
.701\end{array}$ & $\begin{array}{r}.0113 \\
.0148 \\
.0201 \\
.0271 \\
.0378\end{array}$ & $\begin{array}{l}-.0060 \\
-.0072 \\
-.0089 \\
-.0101 \\
-.0111\end{array}$ \\
\hline 21.3 & $\begin{array}{l}120 \\
125 \\
130 \\
135 \\
140\end{array}$ & $\begin{array}{l}.526 \\
.597 \\
.632 \\
.655 \\
.616\end{array}$ & $\begin{array}{r}.0147 \\
.0177 \\
.0226 \\
.0297 \\
.0393\end{array}$ & $\begin{array}{l}-.0078 \\
-.0083 \\
-.0098 \\
-.0112 \\
-.0113\end{array}$ \\
\hline 29.3 & $\begin{array}{l}120 \\
125 \\
130 \\
135 \\
140\end{array}$ & $\begin{array}{l}.352 \\
.448 \\
.526 \\
.590 \\
.625\end{array}$ & $\begin{array}{r}.0224 \\
.0237 \\
.0276 \\
.0334 \\
.0429\end{array}$ & $\begin{array}{l}-.0109 \\
-.0110 \\
-.0107 \\
-.0109 \\
-.0111\end{array}$ \\
\hline 40.8 & $\begin{array}{l}120 \\
125 \\
130 \\
135 \\
140\end{array}$ & $\begin{array}{l}.261 \\
.317 \\
.394 \\
.497 \\
.557\end{array}$ & $\begin{array}{r}.0315 \\
.0347 \\
.0377 \\
.0406 \\
.0487\end{array}$ & $\begin{array}{l}-.0116 \\
-.0124 \\
-.0118 \\
-.0100 \\
-.0096\end{array}$ \\
\hline
\end{tabular}




\begin{tabular}{|c|c|c|c|c|}
\hline $\begin{array}{c}\mathrm{V}_{\infty}^{*} \\
(\text { meters/sec })\end{array}$ & $\begin{array}{l}\mathrm{P}_{i}^{*} \\
(\mathrm{~dB})\end{array}$ & $\mathrm{C}_{\mathrm{D}}$ & $\mathrm{R}_{\mathrm{o}} * / \rho^{*} \mathrm{c}^{*}$ & $x_{t} * / \rho * c *$ \\
\hline 57.9 & $\begin{array}{l}120 \\
125 \\
130 \\
135 \\
140\end{array}$ & $\begin{array}{l}.176 \\
.232 \\
.296 \\
.394 \\
.474\end{array}$ & $\begin{array}{r}.0479 \\
.0488 \\
.0515 \\
.0519 \\
.0580\end{array}$ & $\begin{array}{l}-.0132 \\
-.0121 \\
-.0110 \\
-.0085 \\
-.0062\end{array}$ \\
\hline 71.0 & $\begin{array}{l}120 \\
125 \\
130 \\
135 \\
140\end{array}$ & $\begin{array}{l}.148 \\
.202 \\
.249 \\
.332 \\
.423\end{array}$ & $\begin{array}{r}.0578 \\
.0568 \\
.0618 \\
.0621 \\
.0653\end{array}$ & $\begin{array}{l}-.0121 \\
-.0102 \\
-.0097 \\
-.0075 \\
-.0048\end{array}$ \\
\hline 79.2 & $\begin{array}{l}120 \\
125 \\
130 \\
135 \\
140\end{array}$ & $\begin{array}{l}.132 \\
.166 \\
.224 \\
.292 \\
.372\end{array}$ & $\begin{array}{l}.0633 \\
.0672 \\
.0670 \\
.0689 \\
.0729\end{array}$ & $\begin{array}{l}-.0195 \\
-.0201 \\
-.0178 \\
-.0170 \\
-.0146\end{array}$ \\
\hline
\end{tabular}

Mode1 \#16 $\mathrm{S}^{*} / \mathrm{d}_{3} 6^{*}=5.0 ; \mathrm{N}=36 ; \mathrm{d}_{36} *=1.18 \mathrm{~mm} ; \tau *=1.02 \mathrm{~mm}$; $\mathrm{D}^{*}=50.8 \mathrm{~mm} ; \mathrm{L}^{*}=38.10^{*} \mathrm{~mm} ; \mathrm{f}_{\text {res }}^{*}=717 \mathrm{~Hz} ; \mathrm{T}_{\infty}^{*}=64^{\circ} \mathrm{F} ;$
$\mathrm{P}_{\infty}^{*}=30.15^{\circ} \mathrm{Hg}$

\begin{tabular}{|c|c|c|c|c|}
\hline 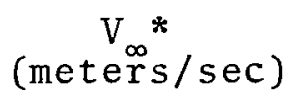 & $\mathrm{P}_{\dot{i}^{*}}^{*}$ & $\mathrm{C}_{\mathrm{D}}$ & $\mathrm{R}_{\mathrm{o}}{ }^{*} / \rho^{*} \mathrm{C}^{*}$ & $x_{t} * / \rho * c *$ \\
\hline 0 & $\begin{array}{r}70 \\
80 \\
90 \\
100 \\
110 \\
115 \\
120 \\
125 \\
130 \\
135 \\
140\end{array}$ & $\begin{array}{l}.098 \\
.172 \\
.295 \\
.473 \\
.609 \\
.653 \\
.684 \\
.6837 \\
.653 \\
.661 \\
.661\end{array}$ & $\begin{array}{l}.0050 \\
.0050 \\
.0052 \\
.0057 \\
.0077 \\
.0094 \\
.0117 \\
.0156 \\
.0222 \\
.0298 \\
.0403\end{array}$ & $\begin{array}{c}0 \\
0 \\
-.0001 \\
-.0004 \\
-.0018 \\
-.0032 \\
-.0047 \\
-.0061 \\
-.0076 \\
-.0080 \\
-.0085\end{array}$ \\
\hline
\end{tabular}




\begin{tabular}{|c|c|c|c|c|}
\hline 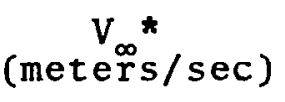 & $\mathrm{P}_{\mathbf{i}^{*}}{ }_{(\mathrm{d} B)}$ & $\mathrm{C}_{\mathrm{D}}$ & $\mathrm{R}_{\mathrm{o}} * / \rho^{*} \mathrm{c} *$ & $x_{t} * / \rho * c *$ \\
\hline 8.1 & $\begin{array}{l}120 \\
125 \\
130 \\
135 \\
140\end{array}$ & $\begin{array}{l}.661 \\
.668 \\
.653 \\
.653 \\
.653\end{array}$ & $\begin{array}{l}.0120 \\
.0161 \\
.0223 \\
.0301 \\
.0408\end{array}$ & $\begin{array}{l}-.0050 \\
-.0060 \\
-.0072 \\
-.0083 \\
-.0087\end{array}$ \\
\hline 13.9 & $\begin{array}{l}120 \\
125 \\
130 \\
135 \\
140\end{array}$ & $\begin{array}{l}.609 \\
.631 \\
.631 \\
.645 \\
.645\end{array}$ & $\begin{array}{l}.0126 \\
.0165 \\
.0226 \\
.0301 \\
.0410\end{array}$ & $\begin{array}{l}-.0063 \\
-.0076 \\
-.0089 \\
-.0096 \\
-.0096\end{array}$ \\
\hline 21.0 & $\begin{array}{l}120 \\
125 \\
130 \\
135 \\
140\end{array}$ & $\begin{array}{l}.462 \\
.537 \\
.575 \\
.589 \\
.624\end{array}$ & $\begin{array}{r}.0166 \\
.0195 \\
.0248 \\
.0328 \\
.0423\end{array}$ & $\begin{array}{l}-.0085 \\
-.0089 \\
-.0097 \\
-.0112 \\
-.0108\end{array}$ \\
\hline 28.9 & $\begin{array}{l}120 \\
125 \\
130 \\
135 \\
140\end{array}$ & $\begin{array}{l}.331 \\
.412 \\
.484 \\
.549 \\
.589\end{array}$ & $\begin{array}{r}.0234 \\
.0254 \\
.0296 \\
.0354 \\
.0448\end{array}$ & $\begin{array}{l}-.0114 \\
-.0114 \\
-.0111 \\
-.0112 \\
-.0115\end{array}$ \\
\hline 40.5 & $\begin{array}{l}120 \\
125 \\
130 \\
135 \\
140\end{array}$ & $\begin{array}{l}.229 \\
.292 \\
.367 \\
.452 \\
.519\end{array}$ & $\begin{array}{l}.0352 \\
.0368 \\
.0395 \\
.0435 \\
.0511\end{array}$ & $\begin{array}{l}-.0133 \\
-.0139 \\
-.0133 \\
-.0122 \\
-.0118\end{array}$ \\
\hline 57.5 & $\begin{array}{l}120 \\
125 \\
130 \\
135 \\
140\end{array}$ & $\begin{array}{l}.172 \\
.216 \\
.269 \\
.343 \\
.412\end{array}$ & $\begin{array}{r}.0408 \\
.0510 \\
.0549 \\
.0580 \\
.0649\end{array}$ & $\begin{array}{l}-.0143 \\
-.0146 \\
-.0147 \\
-.0137 \\
-.0124\end{array}$ \\
\hline 69.5 & $\begin{array}{l}120 \\
125 \\
130 \\
135 \\
140\end{array}$ & $\begin{array}{l}.136 \\
.180 \\
.226 \\
.288 \\
.371\end{array}$ & $\begin{array}{r}.0610 \\
.0618 \\
.0657 \\
.0692 \\
.0721\end{array}$ & $\begin{array}{l}-.0162 \\
-.0161 \\
-.0160 \\
-.0151 \\
-.0131\end{array}$ \\
\hline 78.2 & $\begin{array}{l}120 \\
125 \\
130 \\
135 \\
140\end{array}$ & $\begin{array}{l}.122 \\
.158 \\
.204 \\
.260 \\
.339\end{array}$ & $\begin{array}{r}.0686 \\
.0703 \\
.0731 \\
.0768 \\
.0789\end{array}$ & $\begin{array}{l}-.0176 \\
-.0175 \\
-.0169 \\
-.0163 \\
-.0199\end{array}$ \\
\hline
\end{tabular}


Model \#17 $\mathrm{S}^{*} / \mathrm{d}_{64} *=1.5 ; \mathrm{N}=64 ; \mathrm{d}_{64} *=.89 \mathrm{~mm} ; \tau^{*}=1.02 \mathrm{~mm} ;$

$$
\begin{aligned}
& \mathrm{D}^{*}=50.8 \mathrm{~mm} ; \mathrm{L}^{*}=38.1 \mathrm{~mm} ; \mathrm{f}_{\text {res }}^{*}=567 \mathrm{~Hz} ; \mathrm{T}_{\infty}^{*}=67^{\circ} \mathrm{F} ; \\
& \mathrm{P}_{\infty}^{*}=30^{\prime \prime} \mathrm{Hg} .
\end{aligned}
$$

\begin{tabular}{|c|c|c|c|c|}
\hline $\begin{array}{c}\mathrm{V}_{\infty}{ }^{*} \\
\text { (meters/sec) }\end{array}$ & $\begin{array}{l}\mathrm{P}_{\mathrm{i}}^{*} \\
(\mathrm{~d} B)\end{array}$ & $C_{D}$ & $\mathrm{R}_{0}^{*} / \rho^{*} \mathrm{C}^{*}$ & $x_{t}{ }^{*} / \rho^{*} c^{*}$ \\
\hline 0 & $\begin{array}{r}70 \\
80 \\
90 \\
100 \\
110 \\
115 \\
120 \\
125 \\
130 \\
135 \\
140\end{array}$ & $\begin{array}{l}.077 \\
.134 \\
.237 \\
.357 \\
.470 \\
.510 \\
.530 \\
.561 \\
.555 \\
.561 \\
.568\end{array}$ & $\begin{array}{l}.0060 \\
.0061 \\
.0063 \\
.0072 \\
.0097 \\
.0118 \\
.0154 \\
.0193 \\
.0261 \\
.0346 \\
.0450\end{array}$ & $\begin{array}{c}0 \\
0 \\
-.0001 \\
-.0005 \\
-.0016 \\
-.0023 \\
-.0033 \\
-.0042 \\
-.0054 \\
-.0063 \\
-.0070\end{array}$ \\
\hline 7.3 & $\begin{array}{l}120 \\
125 \\
130 \\
135 \\
140\end{array}$ & $\begin{array}{l}.561 \\
.574 \\
.568 \\
.574 \\
.568\end{array}$ & $\begin{array}{l}.0146 \\
.0190 \\
.0256 \\
.0339 \\
.0458\end{array}$ & $\begin{array}{l}-.0028 \\
-.0036 \\
-.0046 \\
-.0056 \\
-.0068\end{array}$ \\
\hline 13.4 & $\begin{array}{l}120 \\
125 \\
130 \\
135 \\
140\end{array}$ & $\begin{array}{l}.536 \\
.568 \\
.568 \\
.581 \\
.568\end{array}$ & $\begin{array}{l}.0153 \\
.0193 \\
.0257 \\
.0336 \\
.0460\end{array}$ & $\begin{array}{l}-.0026 \\
-.0033 \\
-.0044 \\
-.0051 \\
-.0058\end{array}$ \\
\hline 21.3 & $\begin{array}{l}120 \\
125 \\
130 \\
135 \\
140\end{array}$ & $\begin{array}{l}.512 \\
.536 \\
.542 \\
.524 \\
.555\end{array}$ & $\begin{array}{l}.0156 \\
.0200 \\
.0267 \\
.0351 \\
.0471\end{array}$ & $\begin{array}{l}-.0047 \\
-.0052 \\
-.0055 \\
-.0058 \\
-.0056\end{array}$ \\
\hline 29.0 & $\begin{array}{l}120 \\
125 \\
130 \\
135 \\
140\end{array}$ & $\begin{array}{l}.411 \\
.472 \\
.506 \\
.542 \\
.555\end{array}$ & $\begin{array}{l}.0177 \\
.0221 \\
.0281 \\
.0356 \\
.0469\end{array}$ & $\begin{array}{l}-.0097 \\
-.0081 \\
-.0080 \\
-.0075 \\
-.0072\end{array}$ \\
\hline 41.5 & $\begin{array}{l}120 \\
125 \\
130 \\
135 \\
140\end{array}$ & $\begin{array}{l}.263 \\
.342 \\
.416 \\
.472 \\
.524\end{array}$ & $\begin{array}{l}.0275 \\
.0294 \\
.0334 \\
.0404 \\
.0494\end{array}$ & $\begin{array}{l}-.0157 \\
-.0138 \\
-.0122 \\
-.0107 \\
-.0090\end{array}$ \\
\hline
\end{tabular}




\begin{tabular}{|c|c|c|c|c|}
\hline$\frac{\mathrm{V}_{\infty}^{*}}{(\operatorname{meters} / \mathrm{sec})}$ & $\begin{array}{l}P_{i} * \\
(\bar{d} B)\end{array}$ & $\mathrm{C}_{\mathrm{D}}$ & $\mathrm{R}_{\mathrm{o}} * / \rho * \mathrm{C} *$ & $X_{t}{ }^{*} / \rho^{*} c^{*}$ \\
\hline 57.9 & $\begin{array}{l}120 \\
125 \\
130 \\
135 \\
140\end{array}$ & $\begin{array}{l}.175 \\
.226 \\
.288 \\
.384 \\
.467\end{array}$ & $\begin{array}{r}.0432 \\
.0453 \\
.0481 \\
.0492 \\
.0550\end{array}$ & $\begin{array}{l}-.0196 \\
-.0189 \\
-.0181 \\
-.0148 \\
-.0122\end{array}$ \\
\hline 71.0 & $\begin{array}{l}120 \\
125 \\
130 \\
135 \\
140\end{array}$ & $\begin{array}{l}.139 \\
.178 \\
.237 \\
.312 \\
.384\end{array}$ & $\begin{array}{l}.0561 \\
.0590 \\
.0592 \\
.0606 \\
.0667\end{array}$ & $\begin{array}{l}-.0203 \\
-.0206 \\
-.0201 \\
-.0181 \\
-.0159\end{array}$ \\
\hline 79.2 & $\begin{array}{l}120 \\
125 \\
130 \\
135 \\
140\end{array}$ & $\begin{array}{l}.127 \\
.173 \\
.213 \\
.285 \\
.350\end{array}$ & $\begin{array}{r}.0621 \\
.0608 \\
.0663 \\
.0667 \\
.0730\end{array}$ & $\begin{array}{l}-.0206 \\
-.0199 \\
-.0204 \\
-.0188 \\
-.0177\end{array}$ \\
\hline
\end{tabular}

Mode1 \#18 $\mathrm{S}^{*} / \mathrm{d}_{64} *=2.5 ; \mathrm{N}=64 ; \mathrm{d} *=.89 \mathrm{~mm} ; \tau *=1.02 ; \mathrm{D} *=50.8 \mathrm{~mm}$; $\mathrm{L}^{*}=38.10 \mathrm{~mm} ; f_{\mathrm{res}}{ }^{*}=654 \mathrm{~Hz} ; \mathrm{T}_{\infty}^{*}=66^{\circ} \mathrm{F} ; \mathrm{P}_{\infty}^{*}=29.8^{\prime \prime} \mathrm{Hg}$.

\begin{tabular}{|c|c|c|c|c|}
\hline $\begin{array}{c}\mathrm{V}_{\infty}^{*} \\
\text { (meters/sec) }\end{array}$ & $\begin{array}{l}\mathrm{P}_{i}^{*} \\
\left(\mathrm{~dB}^{*}\right)\end{array}$ & $\mathrm{C}_{\mathrm{D}}$ & $\mathrm{R}_{\mathrm{o}} * / \rho^{*} \mathrm{c} *$ & $x_{t} * / \rho * c *$ \\
\hline 0 & $\begin{array}{r}70 \\
80 \\
90 \\
100 \\
110 \\
120 \\
125 \\
130 \\
135 \\
140\end{array}$ & $\begin{array}{l}.085 \\
.155 \\
.263 \\
.418 \\
.538 \\
.618 \\
.632 \\
.639 \\
.632 \\
.639\end{array}$ & $\begin{array}{r}.0056 \\
.0055 \\
.0057 \\
.0064 \\
.0087 \\
.0133 \\
.0174 \\
.0230 \\
.0312 \\
.0413\end{array}$ & $\begin{array}{c}0 \\
0 \\
0 \\
-.0004 \\
-.0019 \\
-.0035 \\
-.0041 \\
-.0051 \\
-.0062 \\
-.0071\end{array}$ \\
\hline
\end{tabular}




\begin{tabular}{|c|c|c|c|c|}
\hline $\begin{array}{c}\mathrm{V}_{\infty}^{*} \\
(\text { meters/sec })\end{array}$ & $\begin{array}{l}\mathrm{P}_{\mathrm{i}^{*}}^{*} \\
(\mathrm{~dB})\end{array}$ & $C_{D}$ & $\mathrm{R}_{\mathrm{o}}{ }^{*} / \rho^{*} \mathrm{C} *$ & $x_{t}{ }^{*} / \rho^{*} c^{*}$ \\
\hline 7.6 & $\begin{array}{l}120 \\
125 \\
130 \\
135 \\
140\end{array}$ & $\begin{array}{l}.617 \\
.639 \\
.639 \\
.632 \\
.639\end{array}$ & $\begin{array}{r}.0133 \\
.0172 \\
.0231 \\
.0313 \\
.0414\end{array}$ & $\begin{array}{l}-.0035 \\
-.0040 \\
-.0049 \\
-.0059 \\
-.0069\end{array}$ \\
\hline 13.5 & $\begin{array}{l}120 \\
125 \\
130 \\
135 \\
140\end{array}$ & $\begin{array}{l}.590 \\
.617 \\
.625 \\
.625 \\
.617\end{array}$ & $\begin{array}{r}.0139 \\
.0178 \\
.0235 \\
.0316 \\
.0429\end{array}$ & $\begin{array}{l}-.0037 \\
-.0044 \\
-.0054 \\
-.0062 \\
-.0069\end{array}$ \\
\hline 20.8 & $\begin{array}{l}120 \\
125 \\
130 \\
135 \\
140\end{array}$ & $\begin{array}{l}.514 \\
.557 \\
.590 \\
.603 \\
.617\end{array}$ & $\begin{array}{r}.0160 \\
.0198 \\
.0250 \\
.0328 \\
.0428\end{array}$ & $\begin{array}{l}-.0039 \\
-.0045 \\
-.0054 \\
-.0060 \\
-.0070\end{array}$ \\
\hline 28.7 & $\begin{array}{l}120 \\
125 \\
130 \\
135 \\
140\end{array}$ & $\begin{array}{l}.408 \\
.485 \\
.532 \\
.570 \\
.597\end{array}$ & $\begin{array}{r}.0202 \\
.0230 \\
.0278 \\
.0347 \\
.0444\end{array}$ & $\begin{array}{l}-.0049 \\
-.0050 \\
-.0057 \\
-.0061 \\
-.0071\end{array}$ \\
\hline 40.8 & $\begin{array}{l}120 \\
125 \\
130 \\
135 \\
140\end{array}$ & $\begin{array}{l}.292 \\
.355 \\
.478 \\
.508 \\
.570\end{array}$ & $\begin{array}{r}.0282 \\
.0310 \\
.0337 \\
.0390 \\
.0465\end{array}$ & $\begin{array}{l}-.0068 \\
-.0072 \\
-.0071 \\
-.0065 \\
-.0070\end{array}$ \\
\hline 57.2 & $\begin{array}{l}120 \\
125 \\
130 \\
135 \\
140\end{array}$ & $\begin{array}{l}.207 \\
.249 \\
.332 \\
.413 \\
.502\end{array}$ & $\begin{array}{r}.0399 \\
.0444 \\
.0446 \\
.0481 \\
.0529\end{array}$ & $\begin{array}{l}-.0094 \\
-.0096 \\
-.0089 \\
-.0079 \\
-.0074\end{array}$ \\
\hline 69.8 & $\begin{array}{l}120 \\
125 \\
130 \\
135 \\
140\end{array}$ & $\begin{array}{l}.155 \\
.219 \\
.270 \\
.335 \\
.422\end{array}$ & $\begin{array}{r}.0535 \\
.0505 \\
.0549 \\
.0592 \\
.0628\end{array}$ & $\begin{array}{l}-.0109 \\
-.0103 \\
-.0107 \\
-.0094 \\
-.0093\end{array}$ \\
\hline 78.0 & $\begin{array}{l}120 \\
125 \\
130 \\
135 \\
140\end{array}$ & $\begin{array}{l}.141 \\
.184 \\
.249 \\
.299 \\
.403\end{array}$ & $\begin{array}{r}.0586 \\
.0602 \\
.0596 \\
.0664 \\
.0659\end{array}$ & $\begin{array}{l}-.0126 \\
-.0115 \\
-.0110 \\
-.0106 \\
-.0089\end{array}$ \\
\hline
\end{tabular}


Mode1 \#19 $\mathrm{S}^{*} / \mathrm{d}_{64} *=3.5 ; \mathrm{N}=64 ; \mathrm{d}^{*}=.89 \mathrm{~mm} ; \tau^{*}=1.02 \mathrm{~mm} ; \mathrm{D}^{*}=50.8 \mathrm{~mm}$; $\mathrm{L}^{*}=38.1 \mathrm{~mm} ; \mathrm{f}_{\text {res }}^{*}=698 \mathrm{~Hz} ; \mathrm{T}_{\infty}^{*}=64^{\circ} \mathrm{F} ; \mathrm{P}_{\infty}^{*} 29.5^{\prime \prime} \mathrm{Hg}$.

\begin{tabular}{|c|c|c|c|c|}
\hline 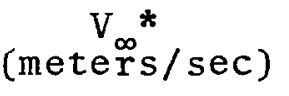 & $\mathrm{P}_{\dot{i}^{*}}^{*}$ & $\mathrm{C}_{\mathrm{D}}$ & $\mathrm{R}_{\mathrm{o}}{ }^{*} / \mathrm{p}^{*} \mathrm{C}^{*}$ & $X_{t} * / \rho^{*} c^{*}$ \\
\hline 0 & $\begin{array}{r}70 \\
80 \\
90 \\
100 \\
110 \\
115 \\
120 \\
125 \\
130 \\
135 \\
140\end{array}$ & $\begin{array}{l}.077 \\
.134 \\
.235 \\
.373 \\
.515 \\
.545 \\
.571 \\
.585 \\
.591 \\
.605 \\
.598\end{array}$ & $\begin{array}{r}.0064 \\
.0065 \\
.0066 \\
.0074 \\
.0074 \\
.0116 \\
.0147 \\
.0193 \\
.0257 \\
.0337 \\
.0457\end{array}$ & $\begin{array}{c}0 \\
0 \\
-.0001 \\
-.0004 \\
-.0020 \\
-.0032 \\
-.0043 \\
-.0051 \\
-.0057 \\
-.0064 \\
-.0073\end{array}$ \\
\hline 7.9 & $\begin{array}{l}120 \\
125 \\
130 \\
135 \\
140\end{array}$ & $\begin{array}{l}.578 \\
.585 \\
.585 \\
.605 \\
.598\end{array}$ & $\begin{array}{r}.0145 \\
.0194 \\
.0260 \\
.0337 \\
.0457\end{array}$ & $\begin{array}{l}-.0043 \\
-.0049 \\
-.0057 \\
-.0062 \\
-.0072\end{array}$ \\
\hline 13.7 & $\begin{array}{l}120 \\
125 \\
130 \\
135 \\
140\end{array}$ & $\begin{array}{l}.546 \\
.571 \\
.578 \\
.591 \\
.598\end{array}$ & $\begin{array}{r}.0153 \\
.0197 \\
.0262 \\
.0344 \\
.0457\end{array}$ & $\begin{array}{l}-.0048 \\
-.0055 \\
-.0064 \\
-.0070 \\
-.0076\end{array}$ \\
\hline 21.3 & $\begin{array}{l}120 \\
125 \\
130 \\
135 \\
140\end{array}$ & $\begin{array}{l}.449 \\
.509 \\
.552 \\
.565 \\
.578\end{array}$ & $\begin{array}{r}.0187 \\
.0221 \\
.0274 \\
.0360 \\
.0472\end{array}$ & $\begin{array}{l}-.0056 \\
-.0061 \\
-.0068 \\
-.0076 \\
-.0080\end{array}$ \\
\hline 29.3 & $\begin{array}{l}120 \\
125 \\
130 \\
135 \\
140\end{array}$ & $\begin{array}{l}.344 \\
.423 \\
.481 \\
.527 \\
.546\end{array}$ & $\begin{array}{r}.0245 \\
.0265 \\
.0315 \\
.0386 \\
.0500\end{array}$ & $\begin{array}{l}-.0070 \\
-.0076 \\
-.0076 \\
-.0080 \\
-.0086\end{array}$ \\
\hline 40.2 & $\begin{array}{l}120 \\
125 \\
130 \\
135 \\
140\end{array}$ & $\begin{array}{l}.252 \\
.321 \\
.395 \\
.470 \\
.515\end{array}$ & $\begin{array}{r}.0337 \\
.0352 \\
.0384 \\
.0435 \\
.0531\end{array}$ & $\begin{array}{l}-.0084 \\
-.0091 \\
-.0088 \\
-.0081 \\
-.0084\end{array}$ \\
\hline
\end{tabular}




\begin{tabular}{|c|c|c|c|c|}
\hline$\frac{V_{\infty}^{*}}{(m e t e r s / \sec )}$ & $\mathrm{P}_{\dot{\mathrm{d}} \mathrm{B})}^{*}$ & $\mathrm{C}_{\mathrm{D}}$ & $\mathrm{R}_{\mathrm{o}} * / \mathrm{\rho}^{*} \mathrm{C} *$ & $X_{t}^{*} / \rho^{*} c^{*}$ \\
\hline 57.9 & $\begin{array}{l}120 \\
125 \\
130 \\
135 \\
140\end{array}$ & $\begin{array}{l}.185 \\
.244 \\
.307 \\
.386 \\
.459\end{array}$ & $\begin{array}{r}.0464 \\
.0469 \\
.0498 \\
.0530 \\
.0598\end{array}$ & $\begin{array}{l}-.0095 \\
-.0100 \\
-.0100 \\
-.0089 \\
-.0079\end{array}$ \\
\hline 71.0 & $\begin{array}{l}120 \\
125 \\
130 \\
135 \\
140\end{array}$ & $\begin{array}{l}.152 \\
.203 \\
.255 \\
.325 \\
.386\end{array}$ & $\begin{array}{l}.0567 \\
.0567 \\
.0602 \\
.0632 \\
.0712\end{array}$ & $\begin{array}{l}-.0103 \\
-.0099 \\
-.0101 \\
-.0093 \\
-.0082\end{array}$ \\
\hline 79.6 & $\begin{array}{l}120 \\
125 \\
130 \\
135 \\
140\end{array}$ & $\begin{array}{l}.134 \\
.175 \\
.230 \\
.303 \\
.360\end{array}$ & $\begin{array}{l}.0644 \\
.0660 \\
.0669 \\
.0678 \\
.0764\end{array}$ & $\begin{array}{l}-.0111 \\
-.0109 \\
-.0104 \\
-.0094 \\
-.0082\end{array}$ \\
\hline
\end{tabular}

Mode1 \#20 $\mathrm{S}^{*} / \mathrm{d}_{64} *=5.0 ; \mathrm{N}=64 ; \mathrm{d}^{*}=.89 \mathrm{~mm} ; \tau^{*}=1.02 \mathrm{~mm} ; \mathrm{D}^{*}=50.8 \mathrm{~mm}$; $\mathrm{L}^{*}=38.1 \mathrm{~mm} ; \mathrm{f}_{\text {res }}{ }^{*}=774 \mathrm{~Hz} ; \mathrm{T}_{\infty}^{*}=66^{\circ} \mathrm{F} ; \mathrm{P}_{\infty}^{*}=29.6^{\prime \prime} \mathrm{Hg}$.

\begin{tabular}{|c|c|c|c|c|}
\hline 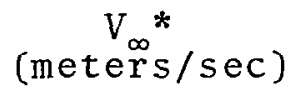 & $\begin{array}{l}\mathrm{p}_{\mathrm{i}^{*}}^{*} \\
(\mathrm{~dB})\end{array}$ & $C_{D}$ & $\mathrm{R}_{0} * / \rho * \mathrm{C}^{*}$ & $X_{t} * / \rho * c *$ \\
\hline 0 & $\begin{array}{r}70 \\
80 \\
90 \\
100 \\
110 \\
120 \\
130 \\
135 \\
140\end{array}$ & $\begin{array}{l}.090 \\
.160 \\
.281 \\
.456 \\
.623 \\
.672 \\
.695 \\
.707 \\
.703\end{array}$ & $\begin{array}{l}.0056 \\
.0056 \\
.0056 \\
.0062 \\
.0079 \\
.0126 \\
.0220 \\
.0293 \\
.0394\end{array}$ & $\begin{array}{c}0 \\
0 \\
0 \\
-.0004 \\
-.0017 \\
-.0041 \\
-.0056 \\
-.0058 \\
-.0064\end{array}$ \\
\hline
\end{tabular}




\begin{tabular}{|c|c|c|c|c|}
\hline$($ meters/sec) & $\mathrm{P}_{\mathrm{i}}$ * & $\mathrm{C}_{\mathrm{D}}$ & $\mathrm{R}_{\mathrm{o}} * / \rho{ }^{*}{ }^{*}$ & $X_{t}{ }^{*} / \rho^{*} c^{*}$ \\
\hline 7.6 & $\begin{array}{l}120 \\
125 \\
130 \\
135 \\
140\end{array}$ & $\begin{array}{r}.679 \\
.687 \\
.695 \\
.695 \\
.703\end{array}$ & $\begin{array}{r}.0125 \\
.0166 \\
.0220 \\
.0297 \\
.0393\end{array}$ & $\begin{array}{l}-.0038 \\
-.0047 \\
-.005 \\
-.0059 \\
-.0070\end{array}$ \\
\hline 13.7 & $\begin{array}{l}120 \\
125 \\
130 \\
135 \\
140\end{array}$ & $\begin{array}{l}.620 \\
.664 \\
.679 \\
.687 \\
.703\end{array}$ & $\begin{array}{l}.0134 \\
.0169 \\
.0223 \\
.0298 \\
.0392\end{array}$ & $\begin{array}{l}-.0051 \\
-.0057 \\
-.0063 \\
-.0068 \\
-.0074\end{array}$ \\
\hline 21.0 & $\begin{array}{l}120 \\
125 \\
130 \\
135 \\
140\end{array}$ & $\begin{array}{l}.527 \\
.592 \\
.627 \\
.649 \\
.679\end{array}$ & $\begin{array}{r}.0156 \\
.0188 \\
.0240 \\
.0314 \\
.0400\end{array}$ & $\begin{array}{l}-.0063 \\
-.0067 \\
-.0074 \\
-.0080 \\
-.0101\end{array}$ \\
\hline 28.6 & $\begin{array}{l}120 \\
125 \\
130 \\
135 \\
140\end{array}$ & $\begin{array}{l}.395 \\
.459 \\
.552 \\
.599 \\
.656\end{array}$ & $\begin{array}{r}.0208 \\
.0242 \\
.0273 \\
.0341 \\
.0419\end{array}$ & $\begin{array}{l}-.0083 \\
-.0089 \\
-.0085 \\
-.0084 \\
-.0085\end{array}$ \\
\hline 40.7 & $\begin{array}{l}120 \\
125 \\
130 \\
135 \\
140\end{array}$ & $\begin{array}{l}.274 \\
.337 \\
.424 \\
.521 \\
.599\end{array}$ & $\begin{array}{r}.0307 \\
.0334 \\
.0355 \\
.0392 \\
.0459\end{array}$ & $\begin{array}{l}-.0104 \\
-.0110 \\
-.0111 \\
-.0094 \\
-.0093\end{array}$ \\
\hline 57.0 & $\begin{array}{l}120 \\
125 \\
130 \\
135 \\
140\end{array}$ & $\begin{array}{l}.203 \\
.250 \\
.307 \\
.397 \\
.506\end{array}$ & $\begin{array}{r}.0422 \\
.0457 \\
.0497 \\
.0518 \\
.0547\end{array}$ & $\begin{array}{l}-.0116 \\
-.0124 \\
-.0130 \\
-.0118 \\
-.0105\end{array}$ \\
\hline 69.5 & $\begin{array}{l}120 \\
125 \\
130 \\
135 \\
140\end{array}$ & $\begin{array}{l}.161 \\
.205 \\
.270 \\
.333 \\
.419\end{array}$ & $\begin{array}{r}.0535 \\
.0562 \\
.0567 \\
.0618 \\
.0659\end{array}$ & $\begin{array}{l}-.0129 \\
-.0130 \\
-.0135 \\
-.0130 \\
-.0121\end{array}$ \\
\hline 78.0 & $\begin{array}{l}120 \\
125 \\
130 \\
135 \\
140\end{array}$ & $\begin{array}{l}.144 \\
.179 \\
.238 \\
.303 \\
.395\end{array}$ & $\begin{array}{r}.0602 \\
.0646 \\
.0647 \\
.0681 \\
.0699\end{array}$ & $\begin{array}{l}-.0139 \\
-.0142 \\
-.0140 \\
-.0131 \\
-.0119\end{array}$ \\
\hline
\end{tabular}




\section{REFERENCES}

1. F. Meche1; P. Mertens; and W. Schilz: Research on Sound Propagation in Sound Absorbent Ducts with Superimposed Air Streams. AMRL-TDR-62-140, vol. III, Physik, Inst., Univ. Gottingen, West Germany (1962).

2. B. Phillips: Effects of High Wave Amplitude and Mean Flow on a Helmholtz Resonator. NASA TM X-1582 (1968).

3. D. Ronneberger: The Acoustic Impedance of Holes in the Wa11 of Flow Ducts. Journal of Sound and Vibration, vol. 24, p. $133(1972)$.

4. P. D. Dean: An In Situ Method of Wall Acoustic Impedance Measurement in Flow Ducts. Journal of Sound and Vibration, vol. 34, No. 1, p. 97, (1974).

5. T. Rogers and A. S. Hersh: The Effect of Grazing Flow on the Steady-State Resistance of Isolated Square-Edged Orifices. NASA CR-2681, (1976).

6. K. J. Baumeister and E. J. Rice: Visual Study of the Effect of Grazing Flow on the Oscillatory Flow in a Resonator Orifice. NASA TM X-3288 (1975).

7. A. S. Hersh and T. Rogers, "Fluid Mechanical Model of the Acoustic Impedance of Sma11 Orifices" NASA CR-2682, May, 1976 .

8. E. J. Rice, "A Theoretical Study of the Acoustic-Impedance of Orifices in the Presence of a Steady Grazing Flow", NASA TM X-71903, April (1976).

9. U. Ingard, "On the Theory and Design of Acoustic Resonators", Jour. Acoust. Soc. Am., V. 25, 1037-1062 (1953).

10. V. A. Fok 1941, Doklady Akademii nank SSSR 31 (In Russian) Alternatively see S. N. Rschevkin 1963, A Course of Lectures on the Theory of Sound, London: pergamon Press.

11. E. H. Mellin, "The Acoustic Impedance of Perforates at Medium and High Sound Pressure Levels", Jour. Sound Vib., V. 29, No.1, 1-65 (1973).

12. U. Ingard and H. Ising, "Acoustic Nonlinearity of an Orifice", J. Acoustic Soc. Am., 42, (1967). 


\section{REFERENCES CONT.}

13. Heller, H. H. and B1iss, D. B., "Aerodynamically Induced Pressure Oscillations in Cavities - Physical Mechanisms and Supression Concepts," Tech Rept AFFDL-TR-74-133, Feb 1975, AF Flight Dynamics Laboratory (FY), WrightPatterson Air Force Base, Ohio 45433.

14. F. C. DeMetz and T. M. Farabee, Laminar and Turbulent Shear F1ow. Induced Cavity Resonances", AIAA Paper 77-1293 Presented at the AIAA 4 th Aeroacoustic Conference held in Atlanta, Georgia, Oct. 1977.

15. Rossiter, J. E., "Wind Tunnel Experiments on the F1ow over Rectangular Cavities at Subsonic and Transonic Speeds," Royal Aircraft Establishment, Tech Rept. No. 64037, Oct 1964. 
TABLE I

SUMMARY OF SINGLE ORIFICE RESONATOR GEOMETRIES TESTED

\begin{tabular}{rccccccccc}
\hline $\begin{array}{c}\text { Mode1 } \\
\#\end{array}$ & $\begin{array}{c}\mathrm{d}^{*} \\
(\mathrm{~mm})\end{array}$ & $\begin{array}{c}\mathrm{fres}_{\mathrm{res}} \\
(\mathrm{Hz})\end{array}$ & $\begin{array}{l}\text { S1ope } \\
\mathrm{dC}\end{array} / \mathrm{dn}$ & $\begin{array}{c}\tau * \\
(\mathrm{~mm})\end{array}$ & $\begin{array}{c}\mathrm{D}^{*} \\
(\mathrm{~mm})\end{array}$ & $\begin{array}{c}\mathrm{L}^{*} \\
(\mathrm{~mm})\end{array}$ & $\tau^{*} / \mathrm{d}^{*}$ & $\mathrm{~d}^{*} / \mathrm{D}^{*}$ & $\mathrm{~d}^{*} / \mathrm{L}^{*}$ \\
\hline 1 & .914 & 500 & 2.0 & .51 & 19.05 & 12.7 & .556 & .048 & .071 \\
2 & .914 & 495 & 2.25 & .25 & 19.05 & 25.4 & .278 & .048 & .048 \\
3 & 1.02 & 590 & 2.17 & .81 & 19.05 & 12.7 & .800 & .055 & .053 \\
4 & .91 & 416 & 1.85 & .51 & 19.05 & 25.4 & .800 & .055 & .055 \\
5 & 1.32 & 428 & 1.70 & .81 & 31.75 & 12.7 & .615 & .047 & .042 \\
6 & 1.32 & 493 & 1.70 & .81 & 19.05 & 25.4 & .615 & .069 & .069 \\
7 & 1.61 & 485 & 1.50 & .81 & 31.75 & 12.7 & .504 & .051 & .051 \\
8 & 1.78 & 385 & 1.70 & .51 & 31.75 & 25.4 & .286 & .056 & .072 \\
9 & 1.78 & 653 & 1.80 & .51 & 19.05 & 25.4 & .286 & .093 & .072 \\
10 & 1.85 & 390 & 1.70 & .81 & 31.75 & 25.4 & .438 & .058 & .074 \\
11 & 2.21 & 436 & 1.42 & .81 & 31.75 & 25.4 & .368 & .070 & .070 \\
12 & 2.67 & 422 & 1.70 & .81 & 31.75 & 38.1 & .305 & .084 & .071 \\
13 & 3.56 & 937 & 1.57 & .25 & 19.05 & 38.1 & .071 & .187 & .095 \\
14 & 3.61 & 503 & 1.35 & .81 & 31.75 & 38.1 & .225 & .114 & .095 \\
15 & 7.11 & 484 & 1.35 & 1.02 & 50.80 & 38.10 & .143 & .140 & .184 \\
16 & 7.11 & 892 & 1.13 & 2.03 & 31.75 & 25.4 & .286 & .224 & .280
\end{tabular}


TABLE II

SUMMARY OF RESONATORS TESTED IN THICK ORIFICE STUDY

\begin{tabular}{ccccc}
\hline $\begin{array}{c}\mathrm{D}^{*} \\
(\mathrm{~mm})\end{array}$ & $\begin{array}{c}\mathrm{L}^{*} \\
(\mathrm{~mm})\end{array}$ & $\begin{array}{c}\mathrm{d}^{*} \\
(\mathrm{~mm})\end{array}$ & $\begin{array}{c}\tau^{*} \\
(\mathrm{~mm})\end{array}$ & $\tau^{*} / \mathrm{d}^{*}$ \\
\hline 31.75 & 12.7 & 1.78 & .509 & .286 \\
$"$ & $"$ & $"$ & 1.015 & .571 \\
$"$ & $"$ & $"$ & 2.032 & 1.143 \\
$"$ & $"$ & $"$ & 4.065 & 2.286 \\
$"$ & $"$ & $"$ & 8.127 & 4.571 \\
& $"$ & & 15.875 & 8.929
\end{tabular}




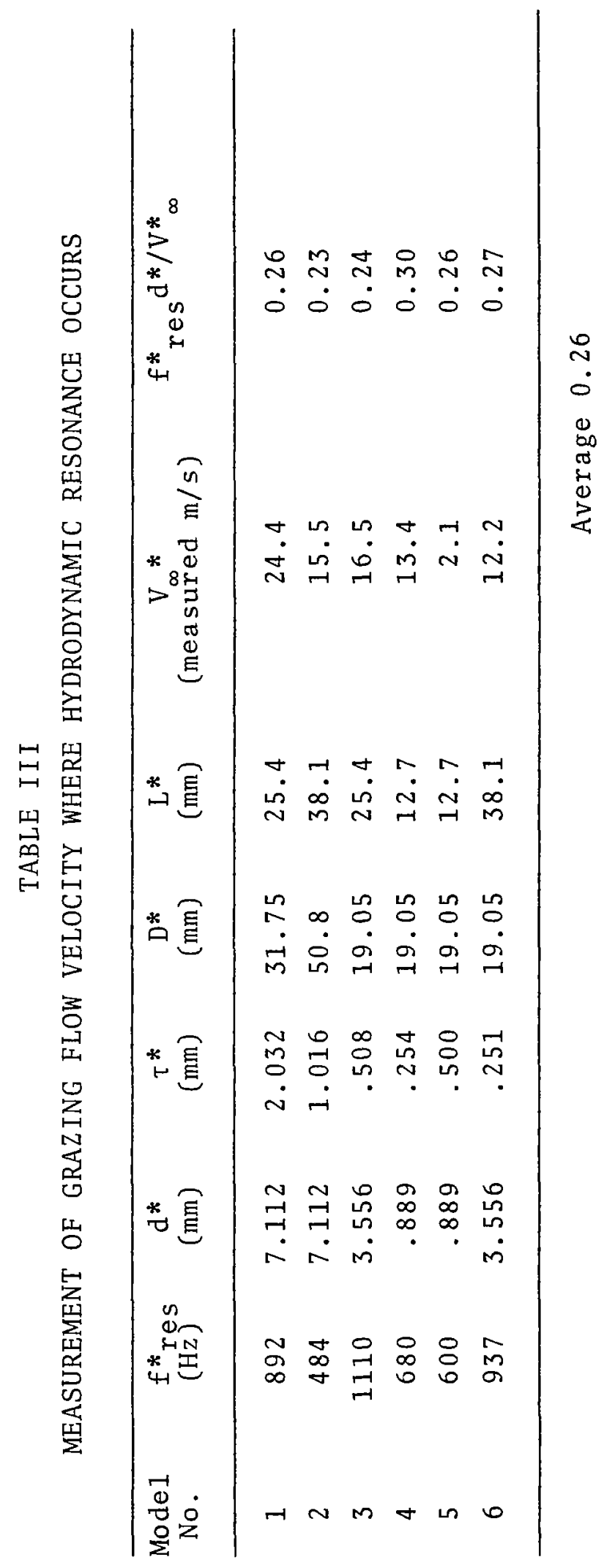


TABLE IV

SUMMARY UF CLUSTERED ORIFICE CONFIGURATION AND RESULTS OF $\mathrm{V}_{\infty}{ }^{*}=0$, $P_{i}{ }^{*}=70 \mathrm{~dB}$ DATA

\begin{tabular}{|c|c|c|c|c|c|c|}
\hline $\mathrm{N}$ & $\underset{(\mathrm{mm})}{\mathrm{d}_{\mathrm{N}}}$ & $S^{*} / d^{*} N$ & $\operatorname{fres}_{(\mathrm{Hz})}$ & $R_{0} * / \rho^{*} c^{*}$ & $\mathrm{de}^{*} / \mathrm{d}_{1} *$ & $\delta * / d_{1} *$ \\
\hline 1 & 7.11 & 0 & 484 & .0020 & .876 & .733 \\
\hline $\begin{array}{l}4 \\
" 1 \\
" 1 \\
" 1\end{array}$ & $\begin{array}{l}3 . i^{56} \\
" 1 \\
" 1\end{array}$ & $\begin{array}{l}2 \\
3 \\
2 \\
3 \\
2.5\end{array}$ & $\begin{array}{l}555 \\
594 \\
553 \\
592 \\
563\end{array}$ & $\begin{array}{l}.0025 \\
.0025 \\
.0024 \\
.0025 \\
.0025\end{array}$ & $\begin{array}{l}.656 \\
.574 \\
.661 \\
.574 \\
.644\end{array}$ & $\begin{array}{l}.513 \\
.431 \\
.518 \\
.431 \\
.501\end{array}$ \\
\hline $\begin{array}{c}16 \\
" 1 \\
11 \\
" 1\end{array}$ & $\begin{array}{l}1.78 \\
" 1 \\
" 1 \\
" 1\end{array}$ & $\begin{array}{l}1.5 \\
2.5 \\
3.5 \\
5.0 \\
6.0\end{array}$ & $\begin{array}{l}564 \\
628 \\
684 \\
709 \\
708\end{array}$ & $\begin{array}{l}.0034 \\
.0032 \\
.0037 \\
.0052 \\
.0040\end{array}$ & $\begin{array}{l}.634 \\
.572 \\
.424 \\
.392 \\
.394\end{array}$ & $\begin{array}{l}.491 \\
.369 \\
.281 \\
.249 \\
.251\end{array}$ \\
\hline $\begin{array}{c}36 \\
11 \\
11 \\
11 \\
11\end{array}$ & $\begin{array}{l}1.19 \\
" 1 \\
" 1 \\
" 1\end{array}$ & $\begin{array}{l}1.5 \\
2.0 \\
2.5 \\
3.5 \\
5.0\end{array}$ & $\begin{array}{l}563 \\
644 \\
663 \\
716 \\
717\end{array}$ & $\begin{array}{l}.0042 \\
.0046 \\
.0040 \\
.0046 \\
.0050\end{array}$ & $\begin{array}{l}.642 \\
.486 \\
.454 \\
.384 \\
.381\end{array}$ & $\begin{array}{l}.499 \\
.343 \\
.311 \\
.241 \\
.238\end{array}$ \\
\hline $\begin{array}{c}64 \\
" 1 \\
" 1\end{array}$ & $\begin{array}{l}.89 \\
" 1 \\
" 1\end{array}$ & $\begin{array}{l}1.5 \\
2.5 \\
3.5 \\
5.0\end{array}$ & $\begin{array}{l}567 \\
654 \\
698 \\
774\end{array}$ & $\begin{array}{r}.0060 \\
.0056 \\
.0064 \\
.0056\end{array}$ & $\begin{array}{l}.635 \\
.467 \\
.404 \\
.323\end{array}$ & $\begin{array}{l}.492 \\
.324 \\
.261 \\
.180\end{array}$ \\
\hline
\end{tabular}




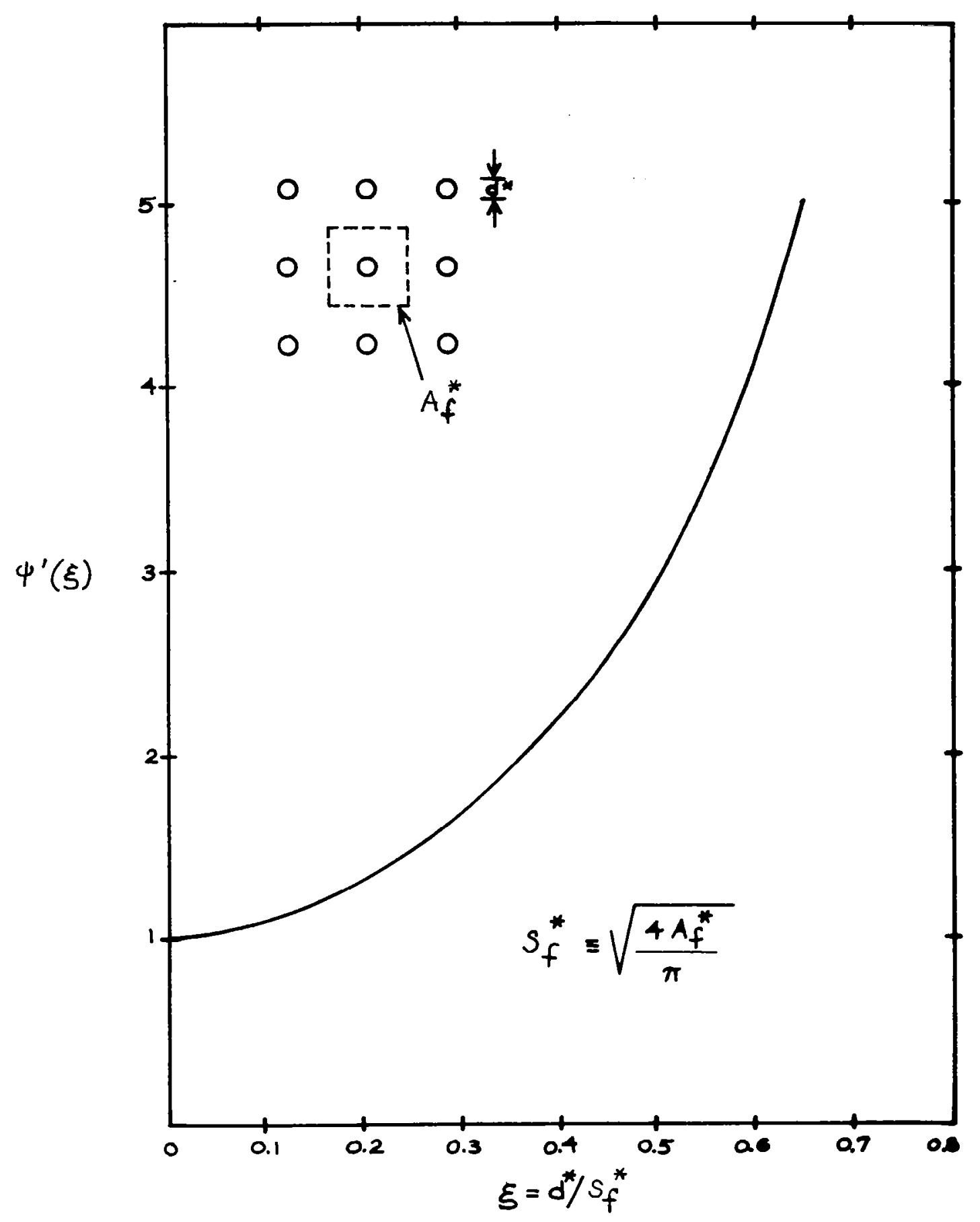

FIGURE 1. DEFINITION OF FOK INTERACTION PARAMETER 


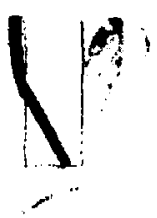

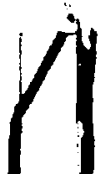

$t=0$

Start of cycle

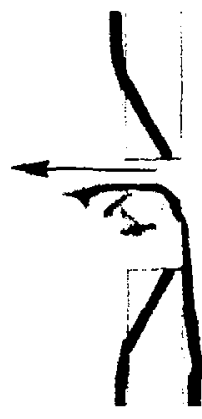

$t=0.178$ Inflow

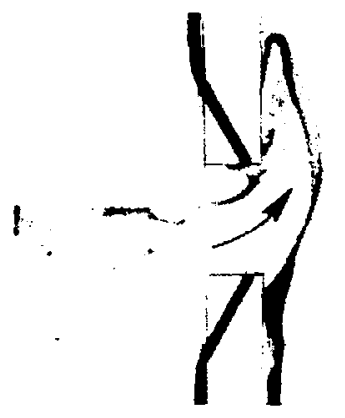

$t=0.364 \mathrm{sec}$ Outflow
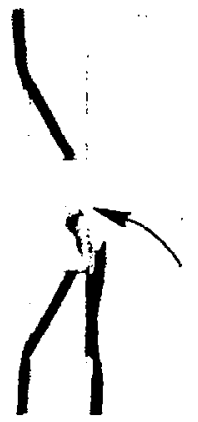

$t=0.061 \mathrm{sec}$ Beginning of inflow

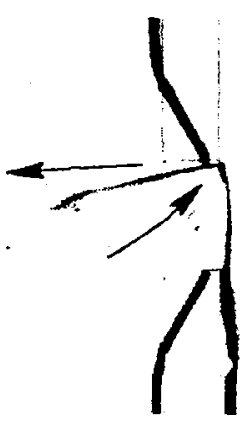

$t=0.236$

Beginning of flow reversal

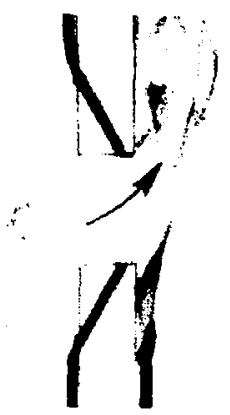

$t=0.44 \mathrm{sec}$ End of outflow

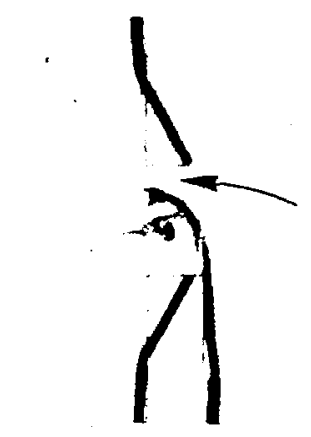

$\mathrm{t}=0.122 \mathrm{sec}$

Inflow

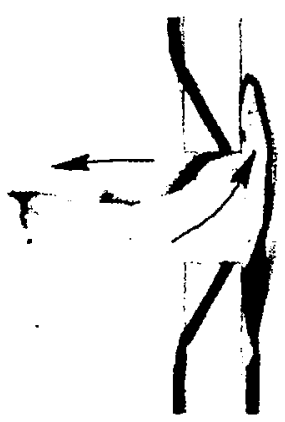

$t=0.312$

Outflow
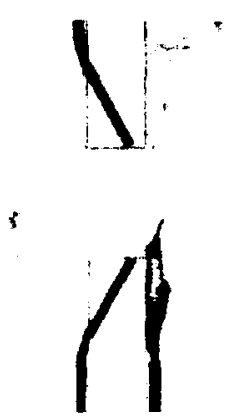

$t=0.5 \mathrm{sec}$

Beginning of new cycle

Figure 2. - Non-linear flow regimes with 0.3 meter/sec grazing flow and intermediate oscillating pressure amplitude $\mathbf{0 . 5}$ amplitude level). Photographs provided by E.J. Rice (Ref. 6) 

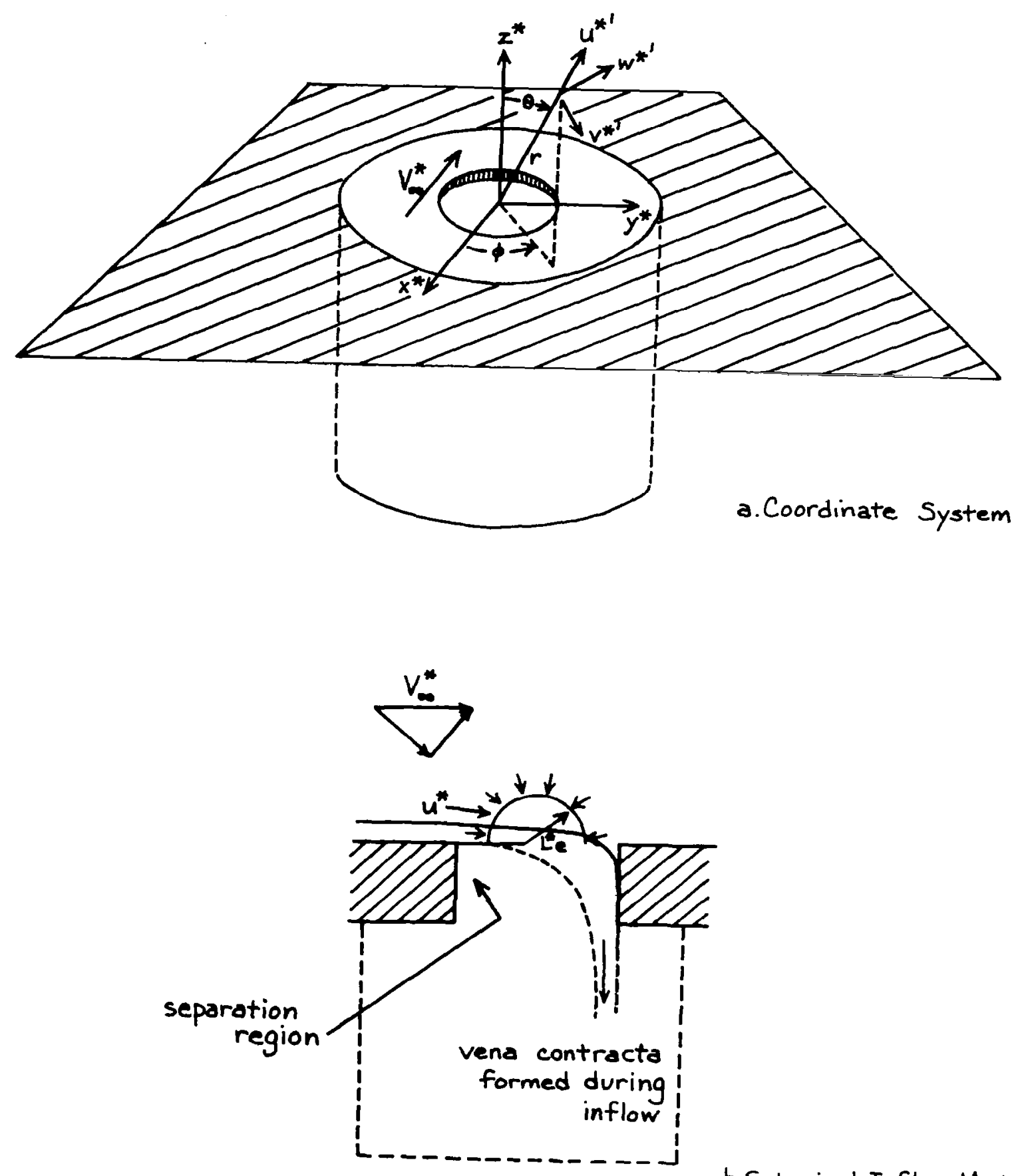

b.Spherical Inflow Madel

FIGURE 3. SCHEMATIC OF SOUND PARTICLE COORDINATE SYSTEM AND SPHERICAL INFLOW MODEL 


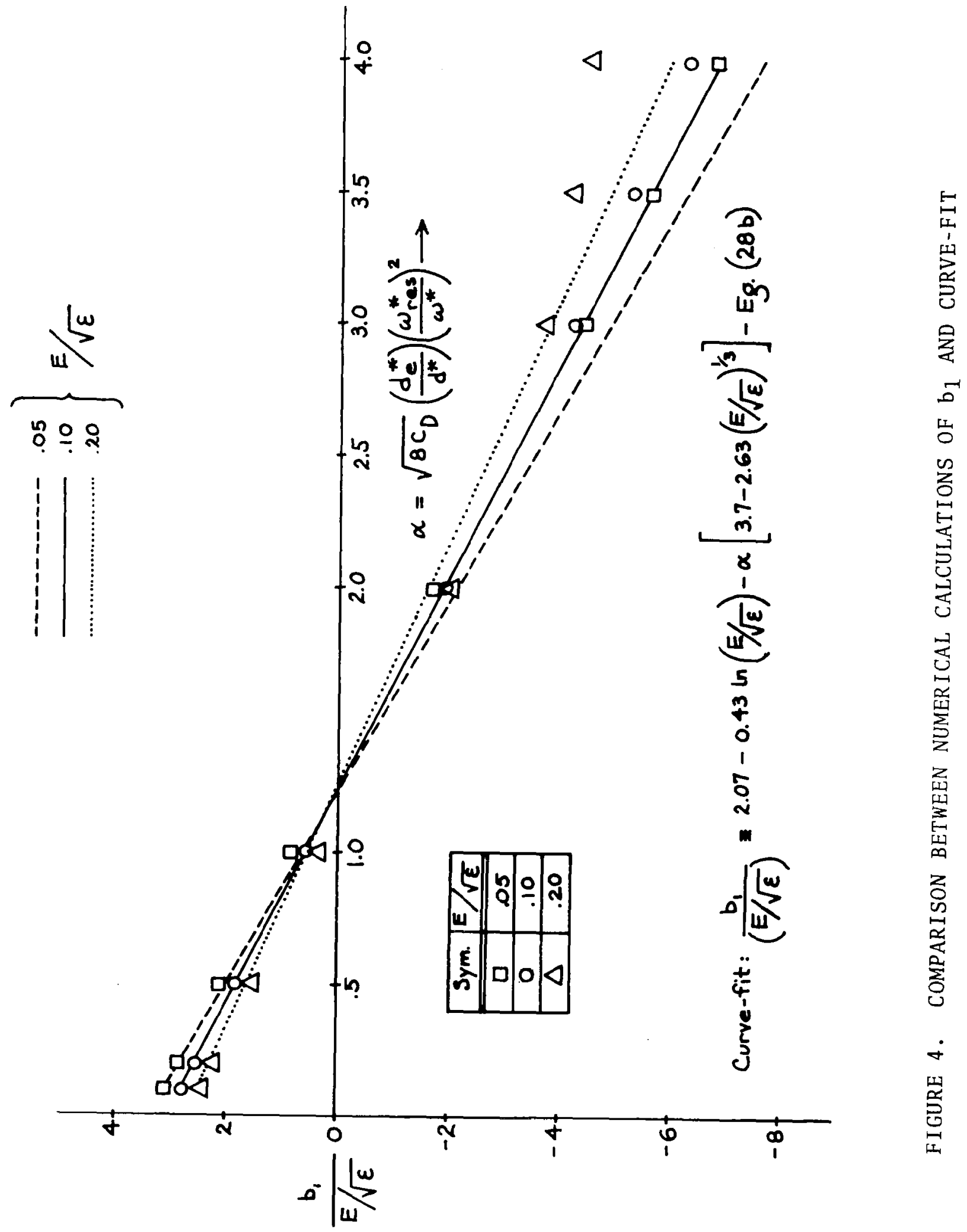




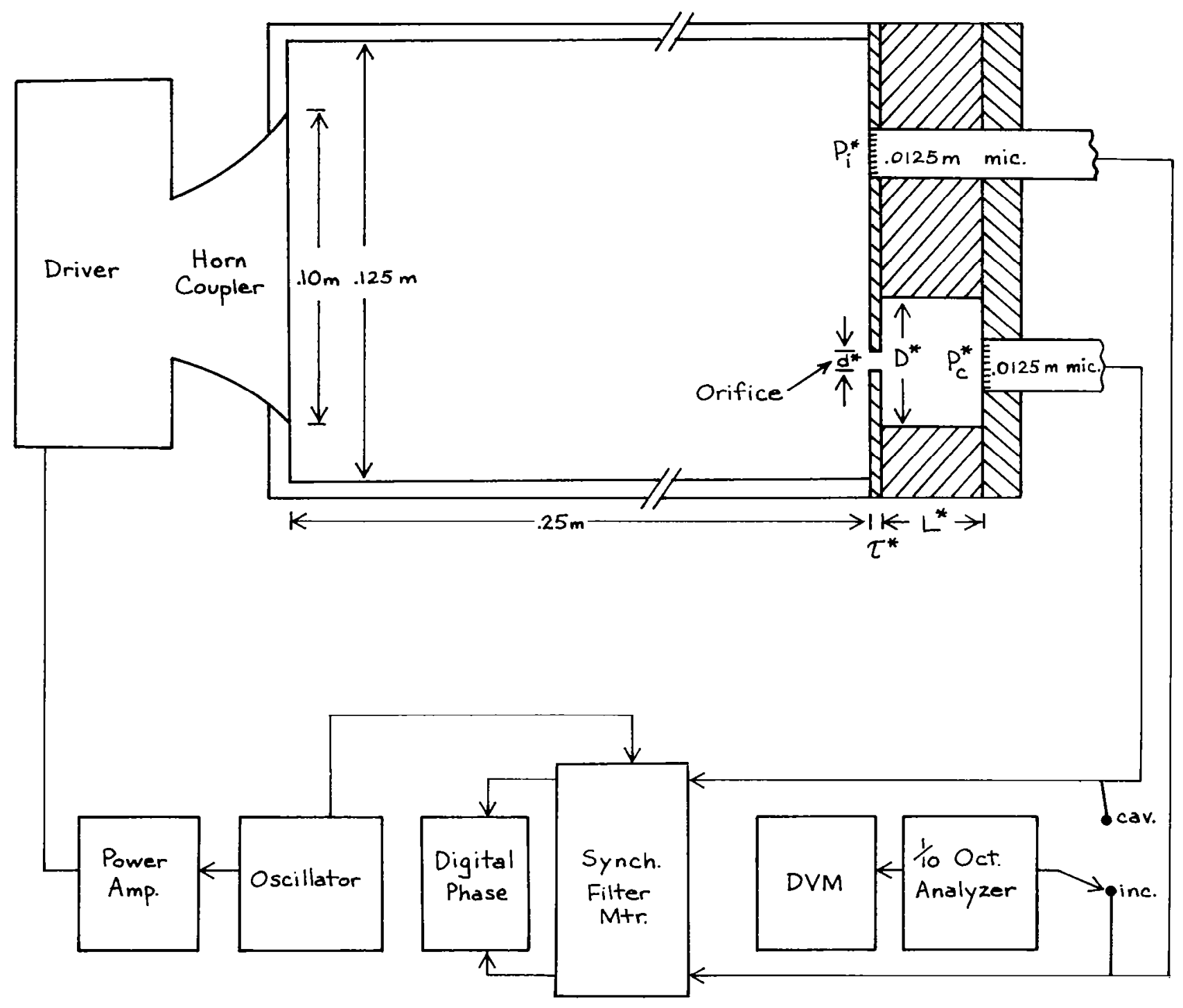

FIGURE 5. SCHEMATIC OF TEST APPARATUS 


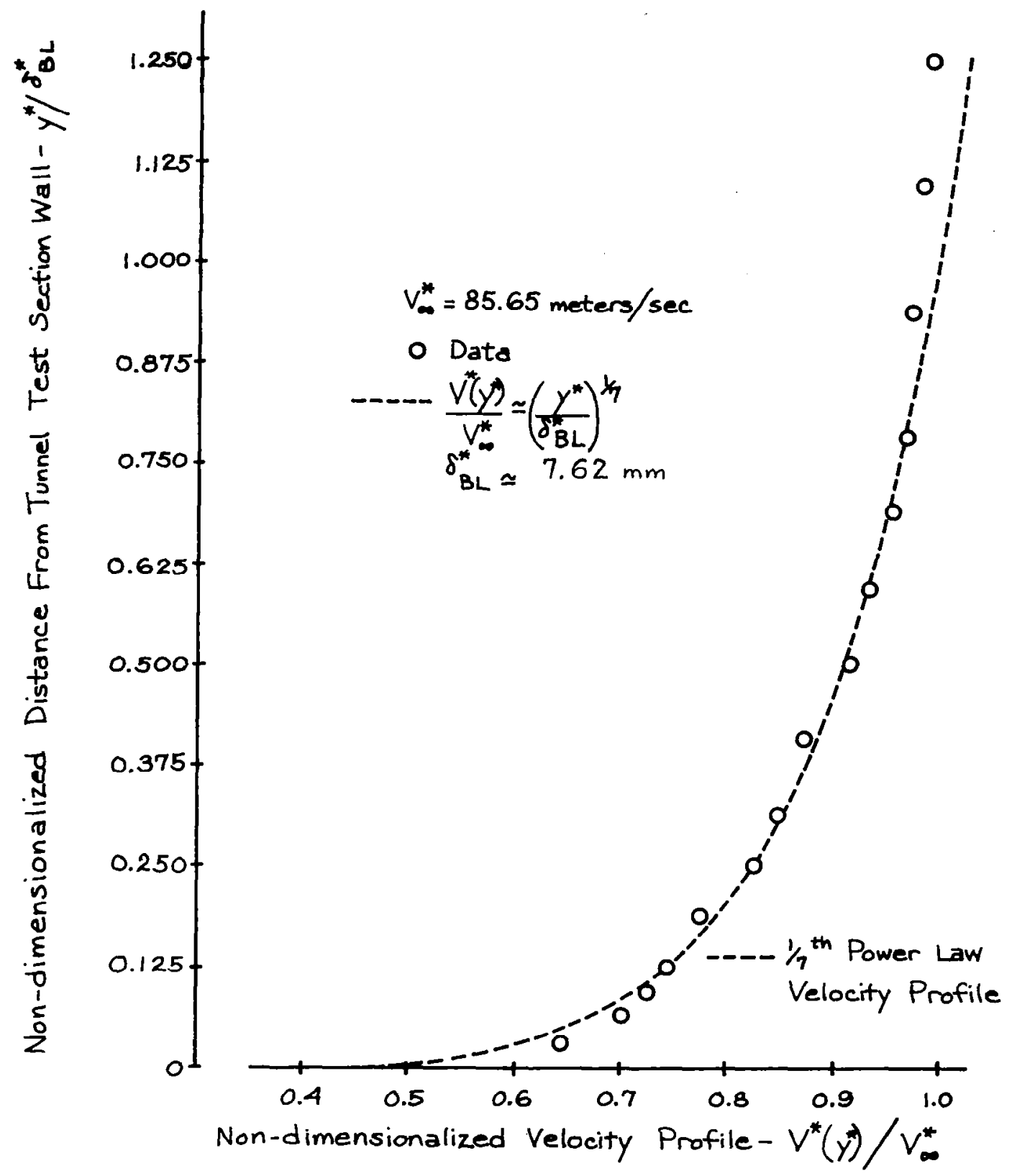

FIGURE 6. TEST SECTION BOUNDARY-LAYER VELOCITY PROFILE 


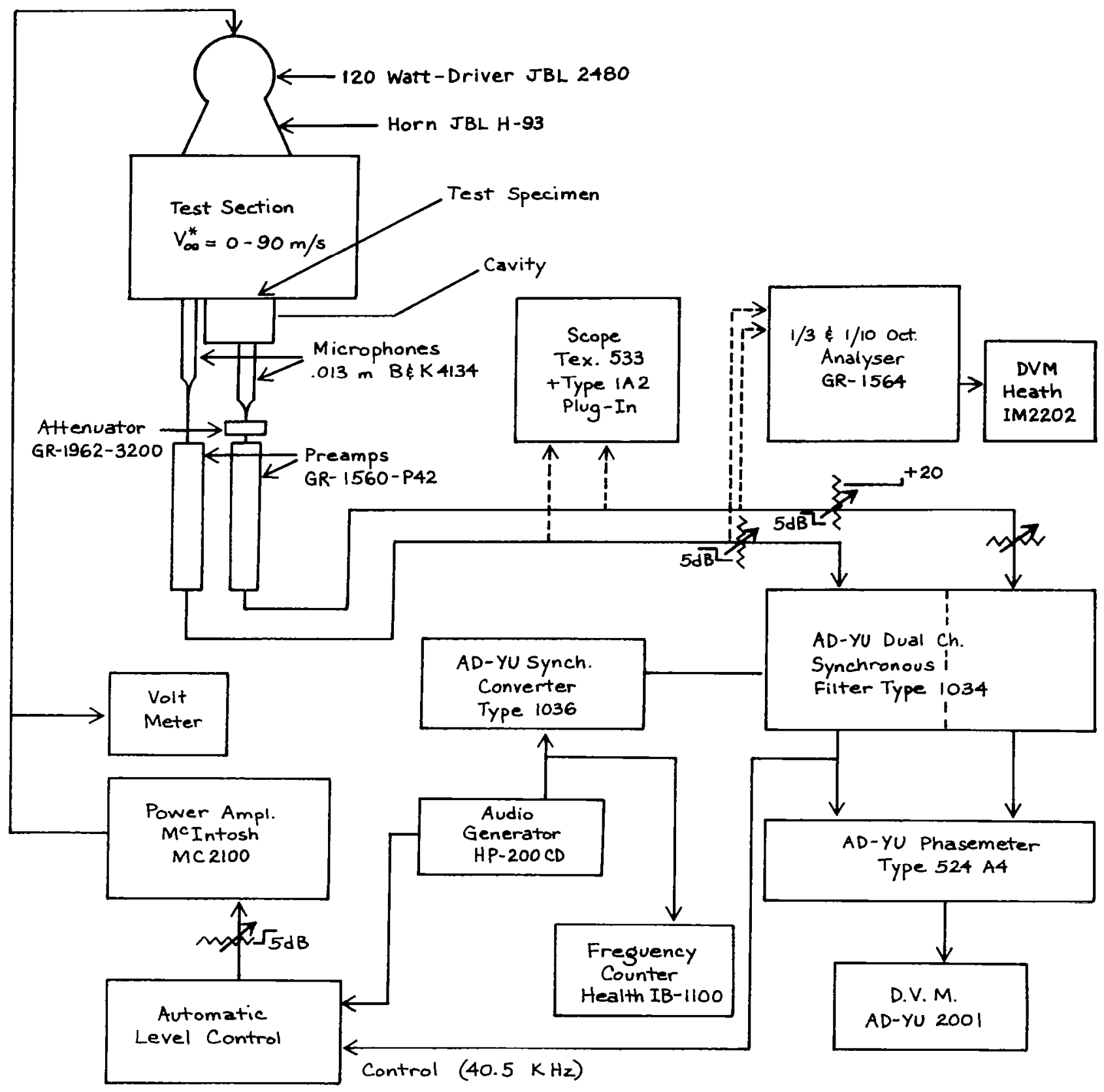

FIGURE 7. SCHEMATIC OF TWO-MICROPHONE MEASUREMENT SYSTEM 


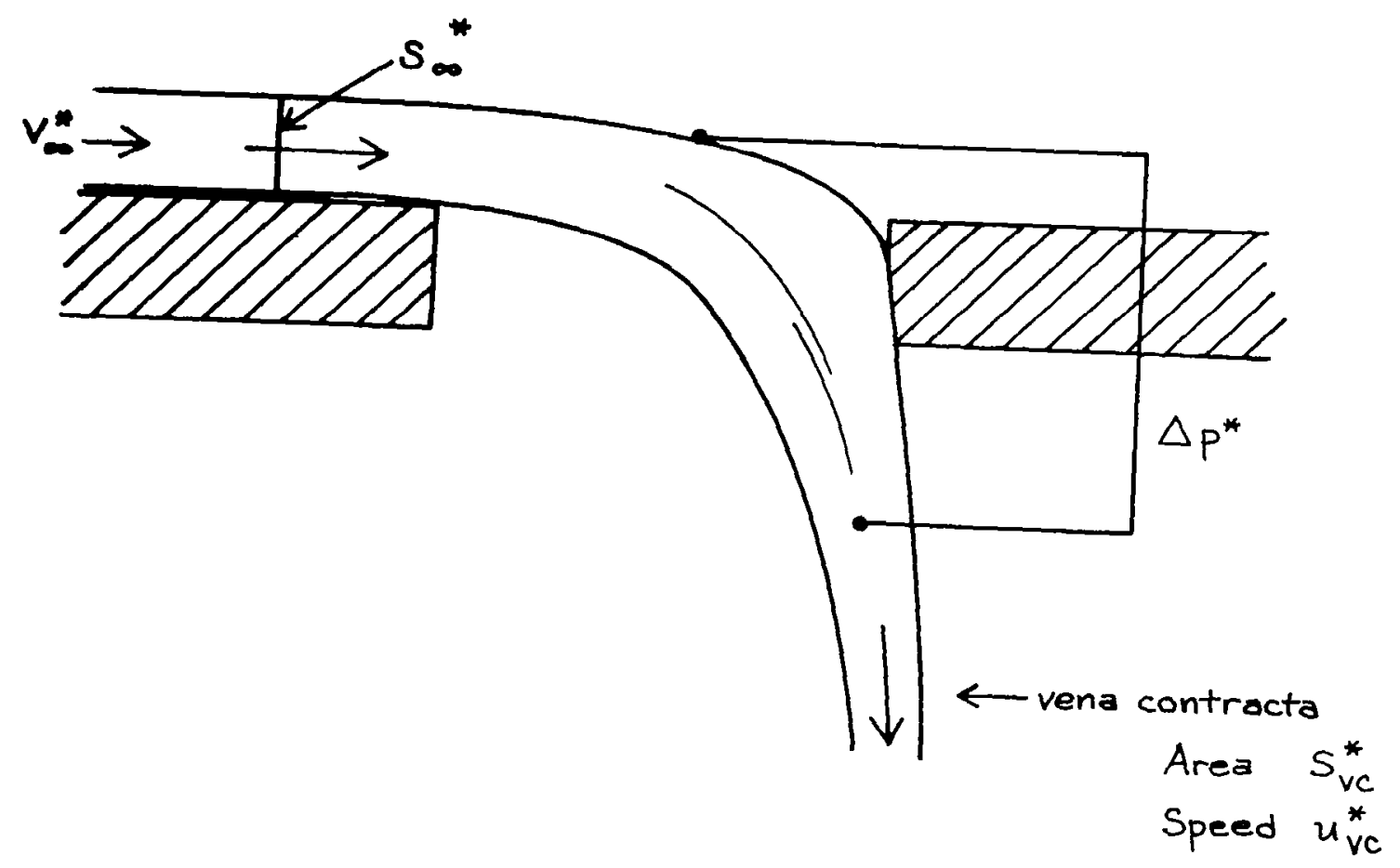

FIGURE 8. SCHEMATIC OF STEADY-STATE DEFLECTION OF GRAZING FLOW THROUGH ORIFICE 


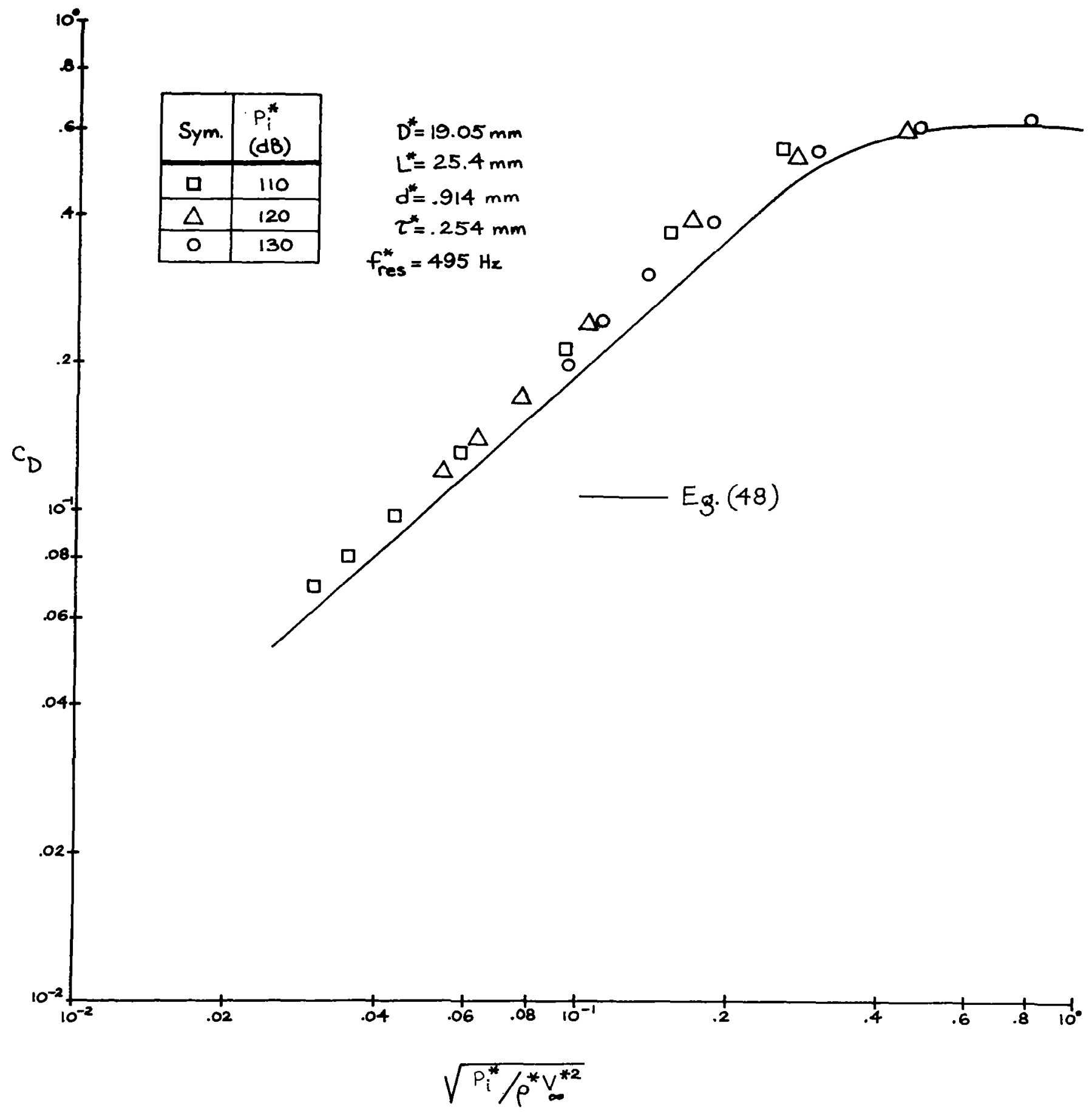

FIGURE 9a. CORRELATION OF MODEL 2 GRAZING FLOW SOUND DATA IN TERMS OF DISCHARGE COEFFICIENT 


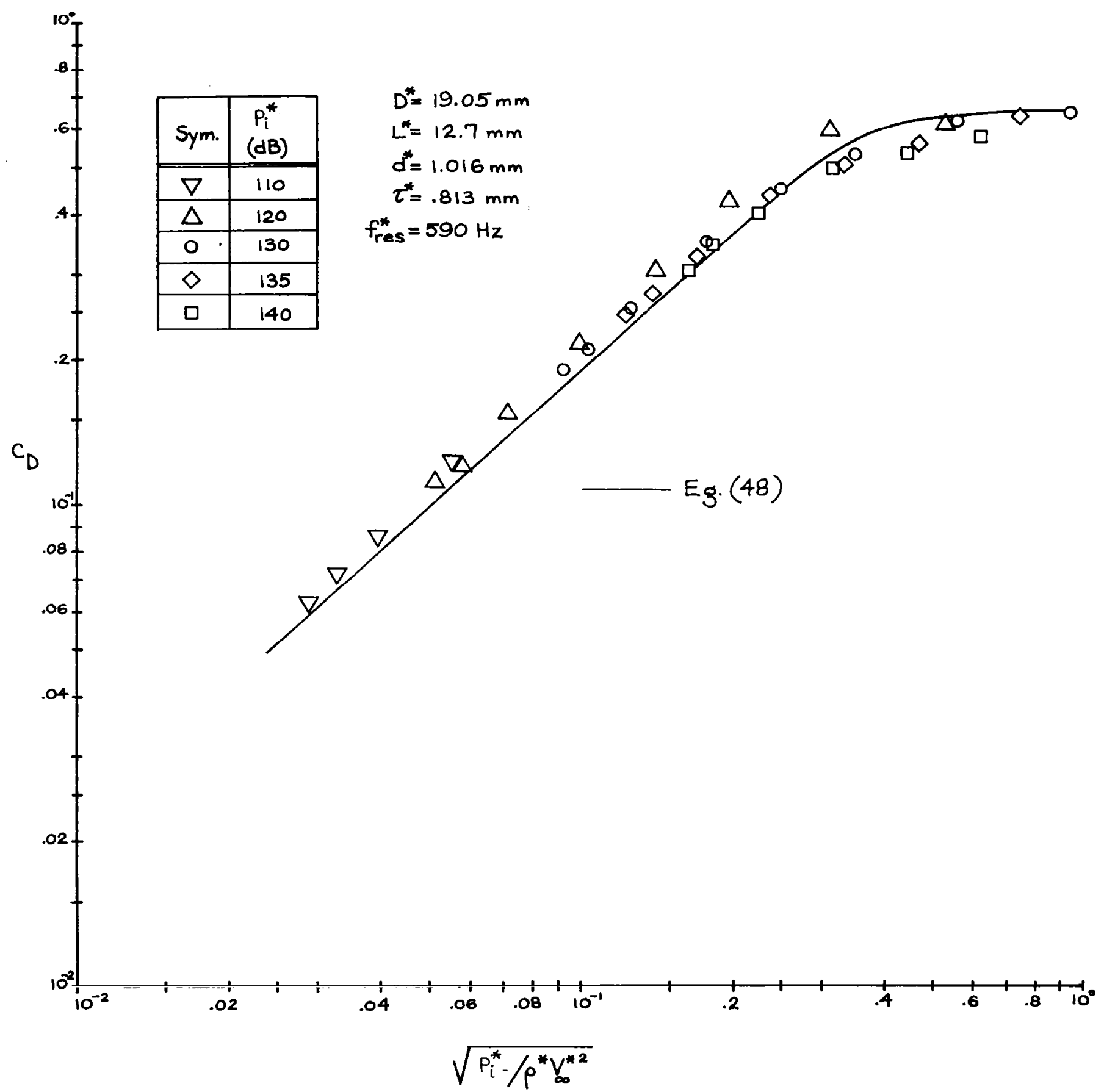

FIGURE 9b. CORRELATION OF MODEL 3 GRAZING FLOW SOUND DATA IN TERMS OF DISCHARGE COEFFICIENT 


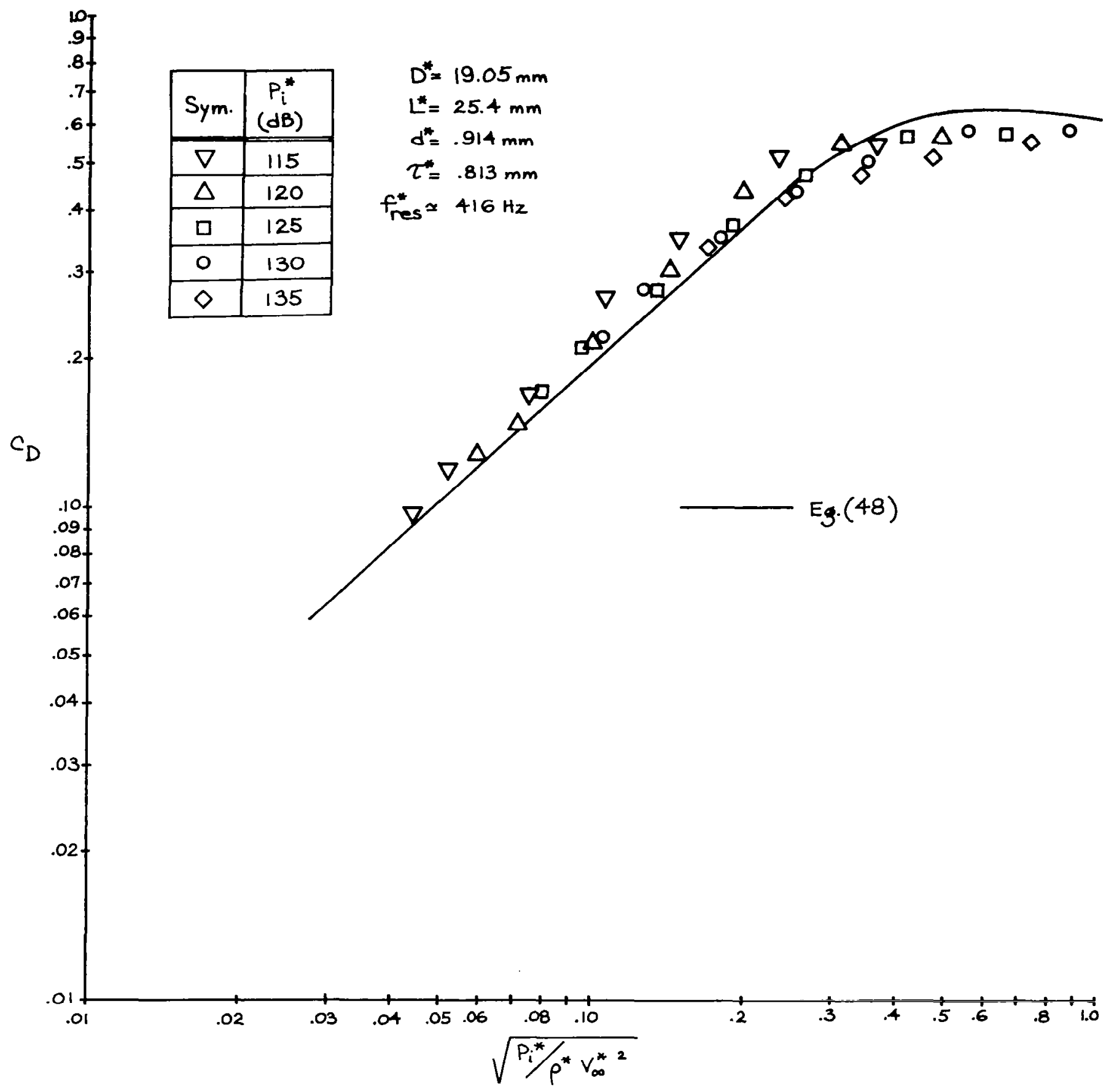

FIGURE 9c. CORRELATION OF MODEL 4 GRAZING FLOW SOUND DATA IN TERMS OF DISCHARGE COEFFICIENT 


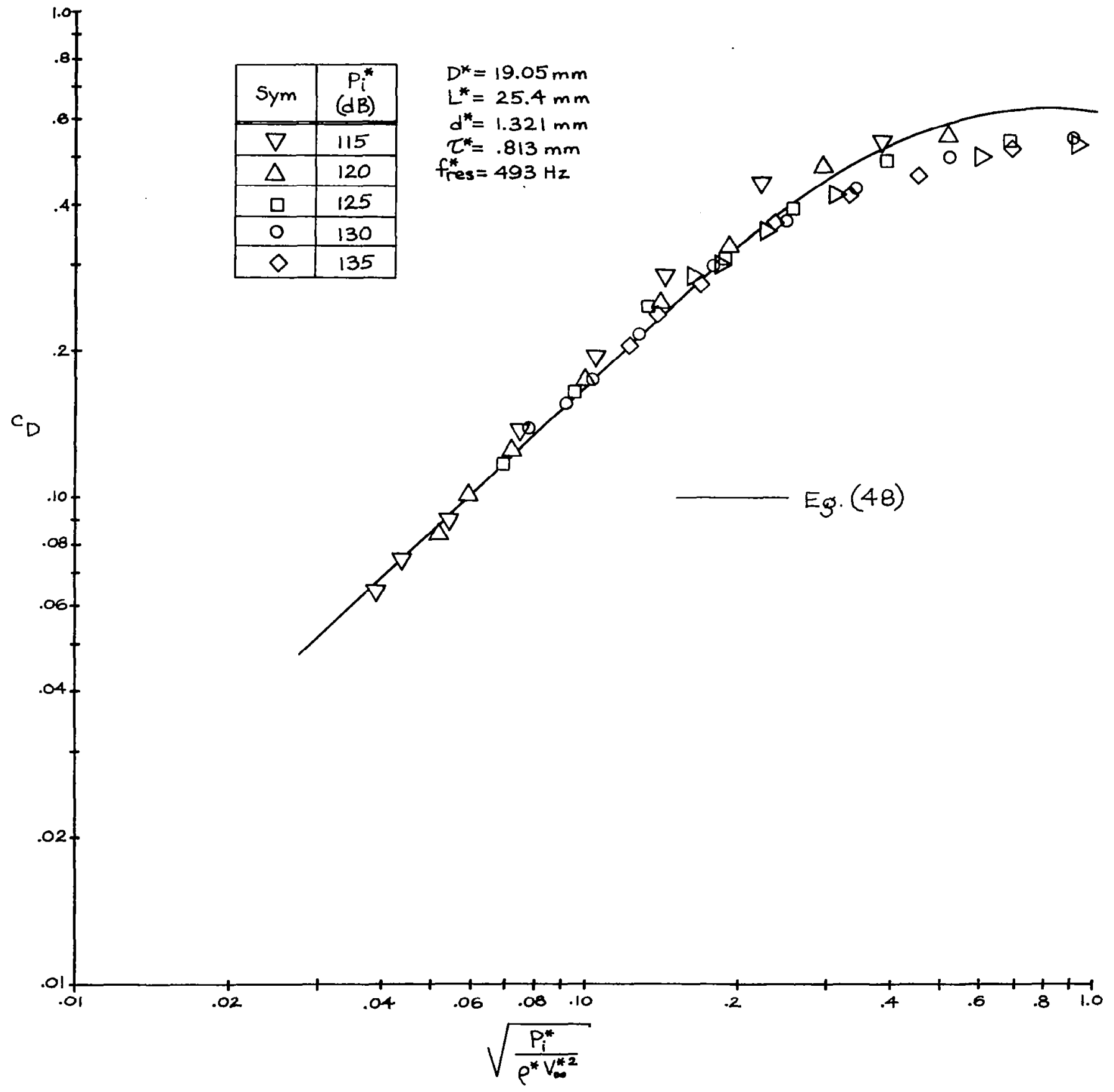

FIGURE 9d. CORRELATION OF MODEL 6 GRAZING FLOW SOUND DATA IN TERMS OF DISCHARGE COEFFICIENT 


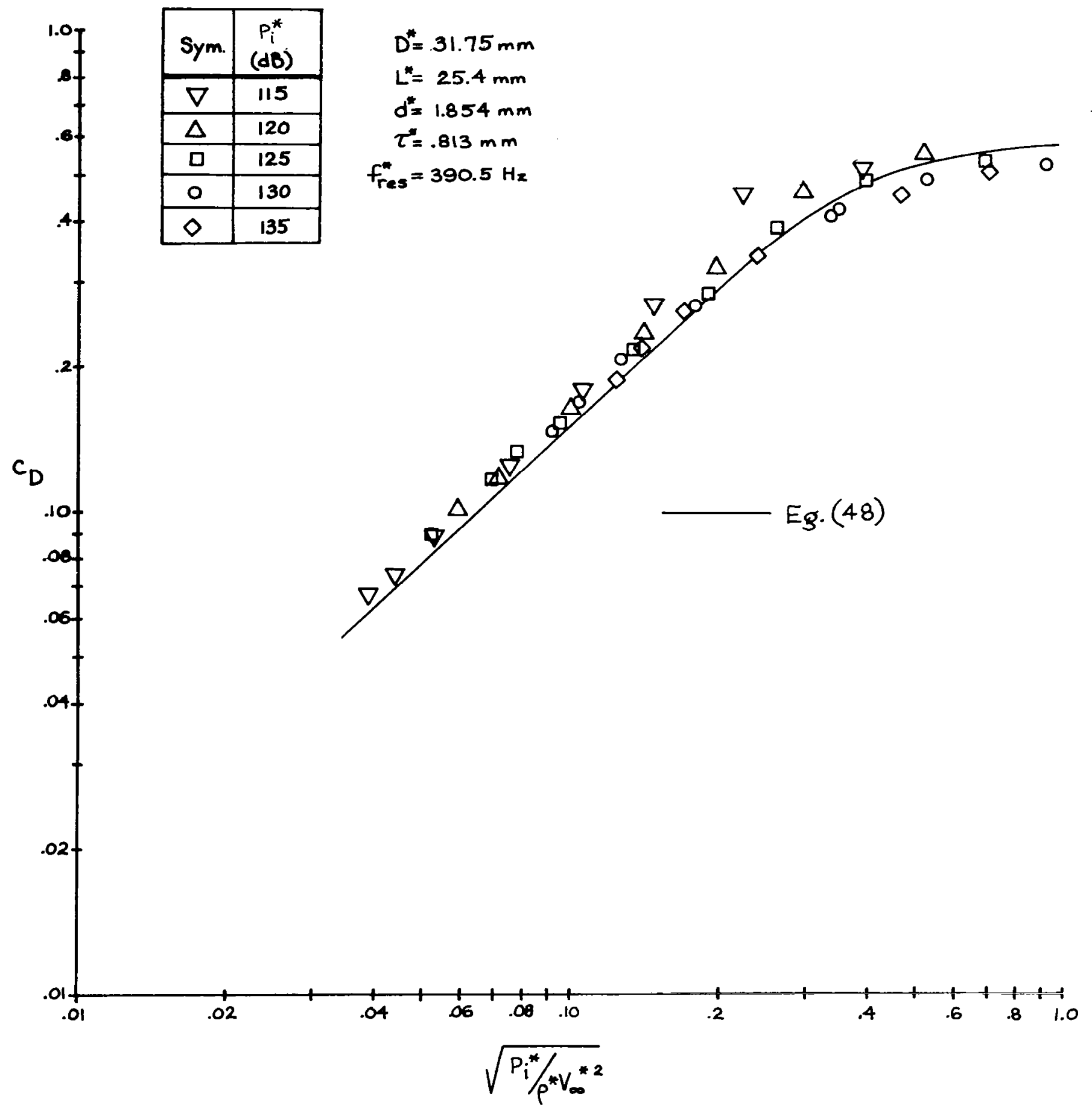

FIGURE $9 e$. CORRELATION OF MODEL 10 GRAZING FLOW SOUND DATA IN TERMS OF DISCHARGE COEFFICIENT 


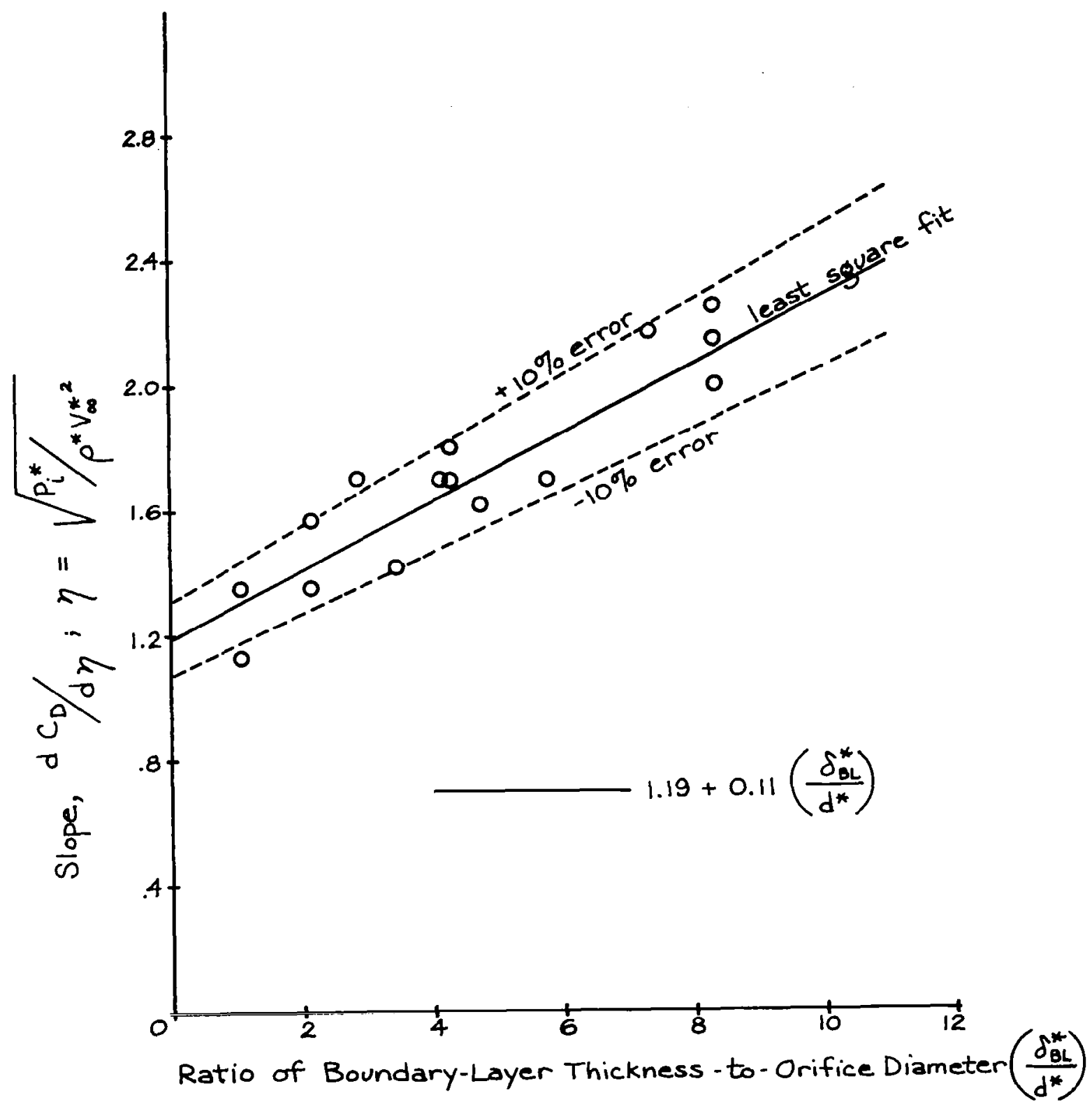

FIGURE 10. EFFECT OF GRAZING FLOW BOUNDARY-LAYER THICKNESS ON LINEAR SLOPE OF DISCHARGE COEFFICIENT 

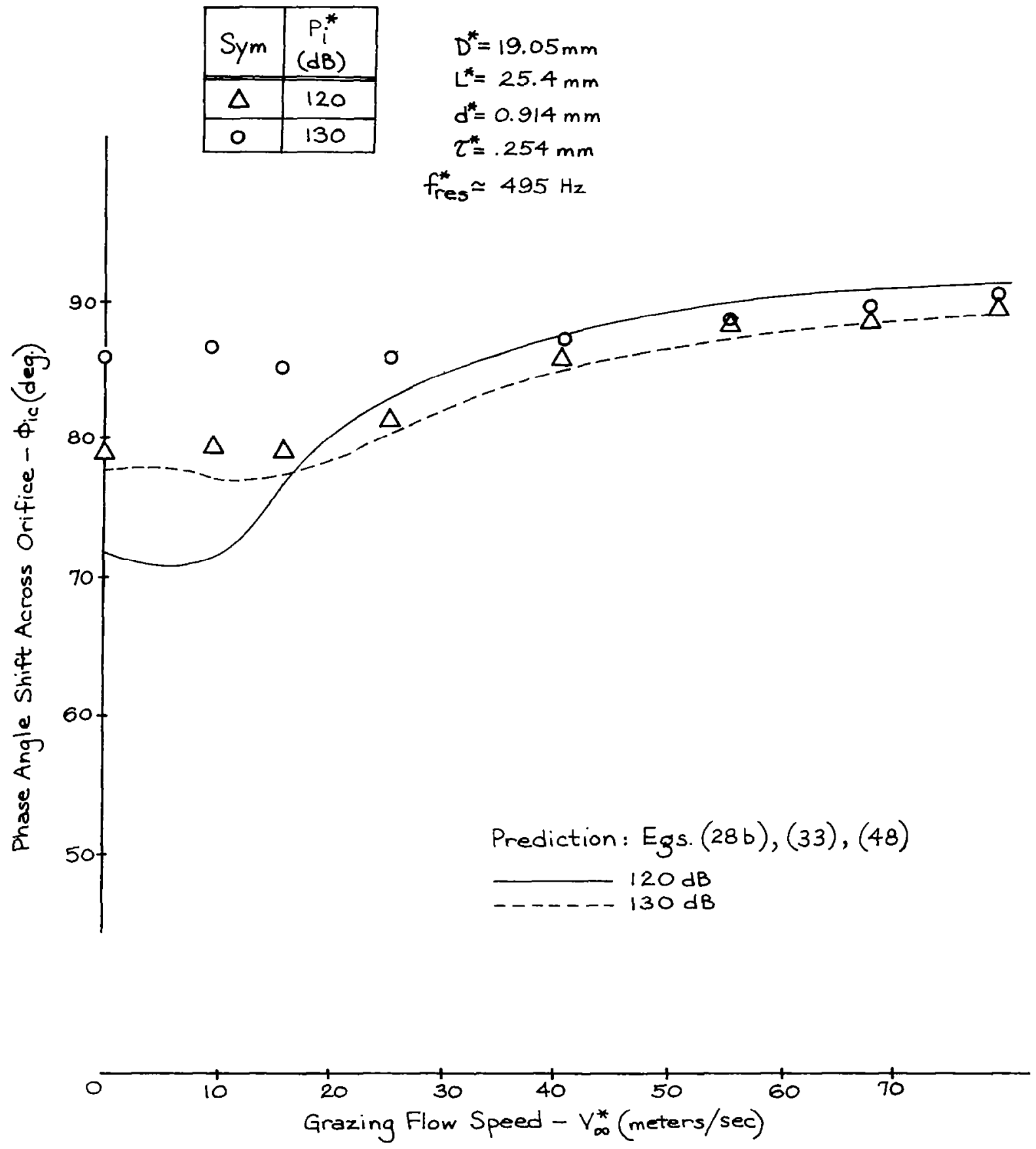

FIGURE 11a. EFFECT OF GRAZING FLOW ON THE PHASE SHIFT ACROSS THE ORIFICE OF MODEL 2 


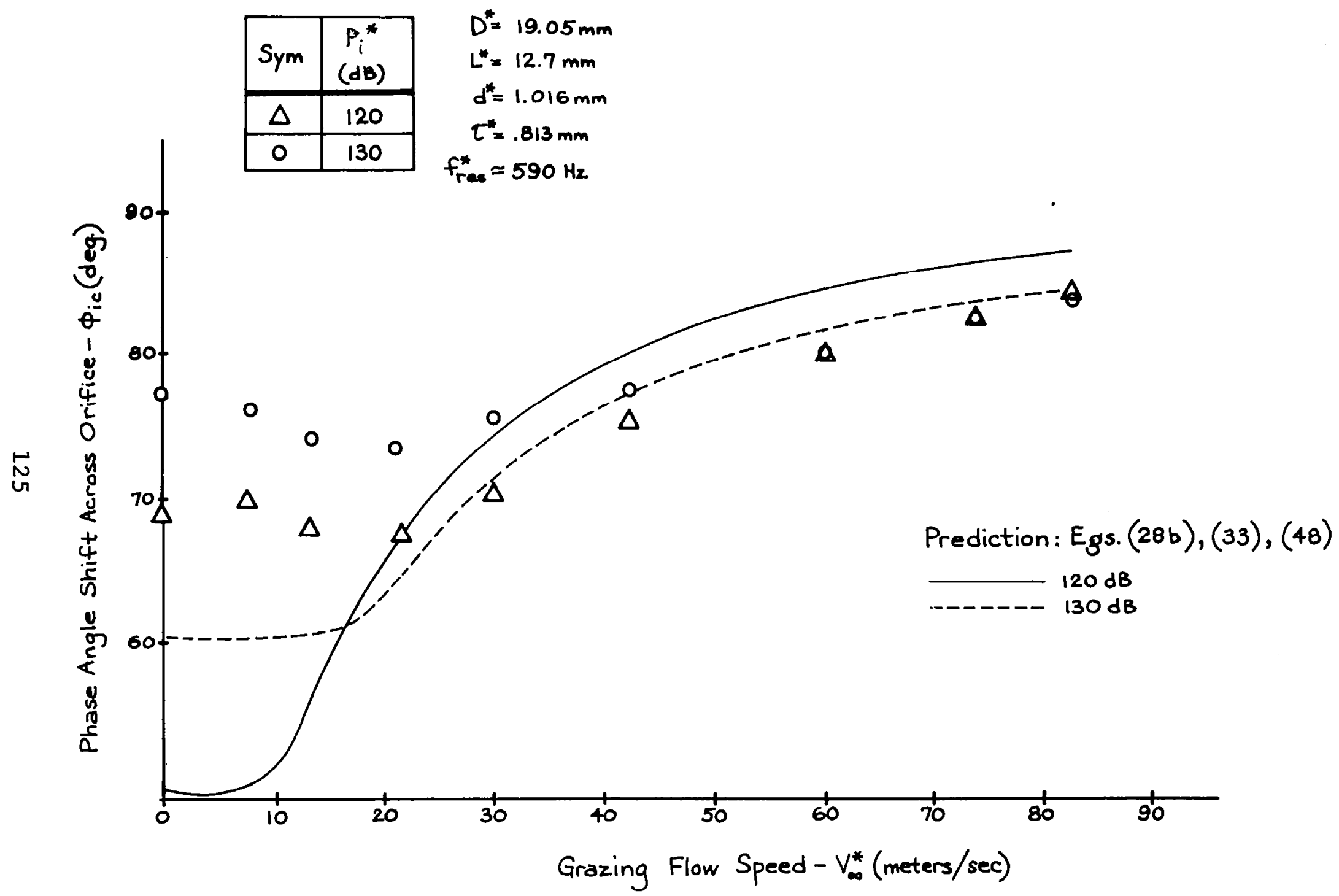

FIGURE 11b. EFFECT OF GRAZING FLOW ON THE PHASE SHIFT ACROSS THE ORIFICE OF MODEL 3 

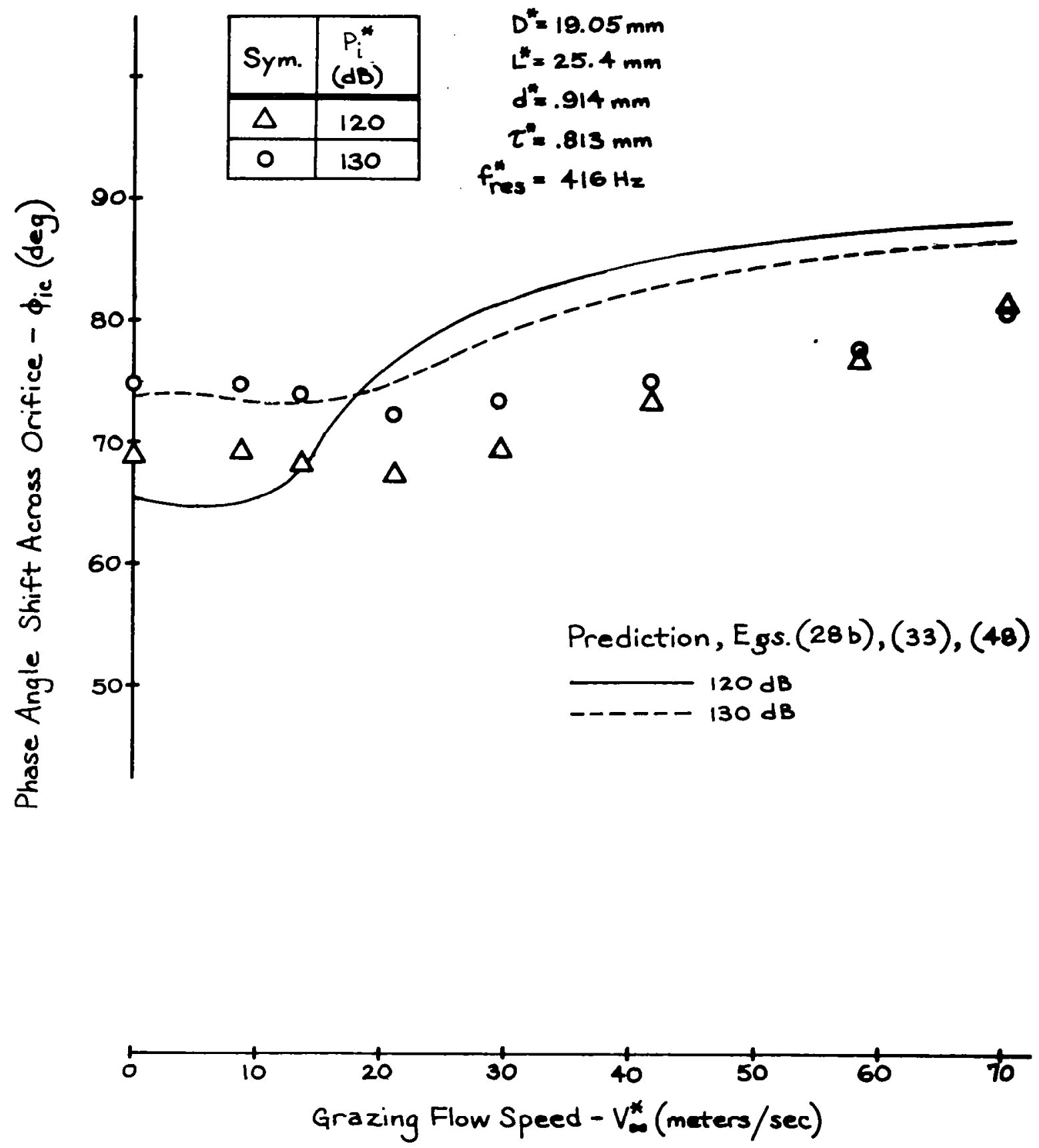

FIGURE 11c. EFFECT OF GRAZING FLOW ON THE PHASE SHIFT ACROSS THE ORIFICE OF MODEL 4 


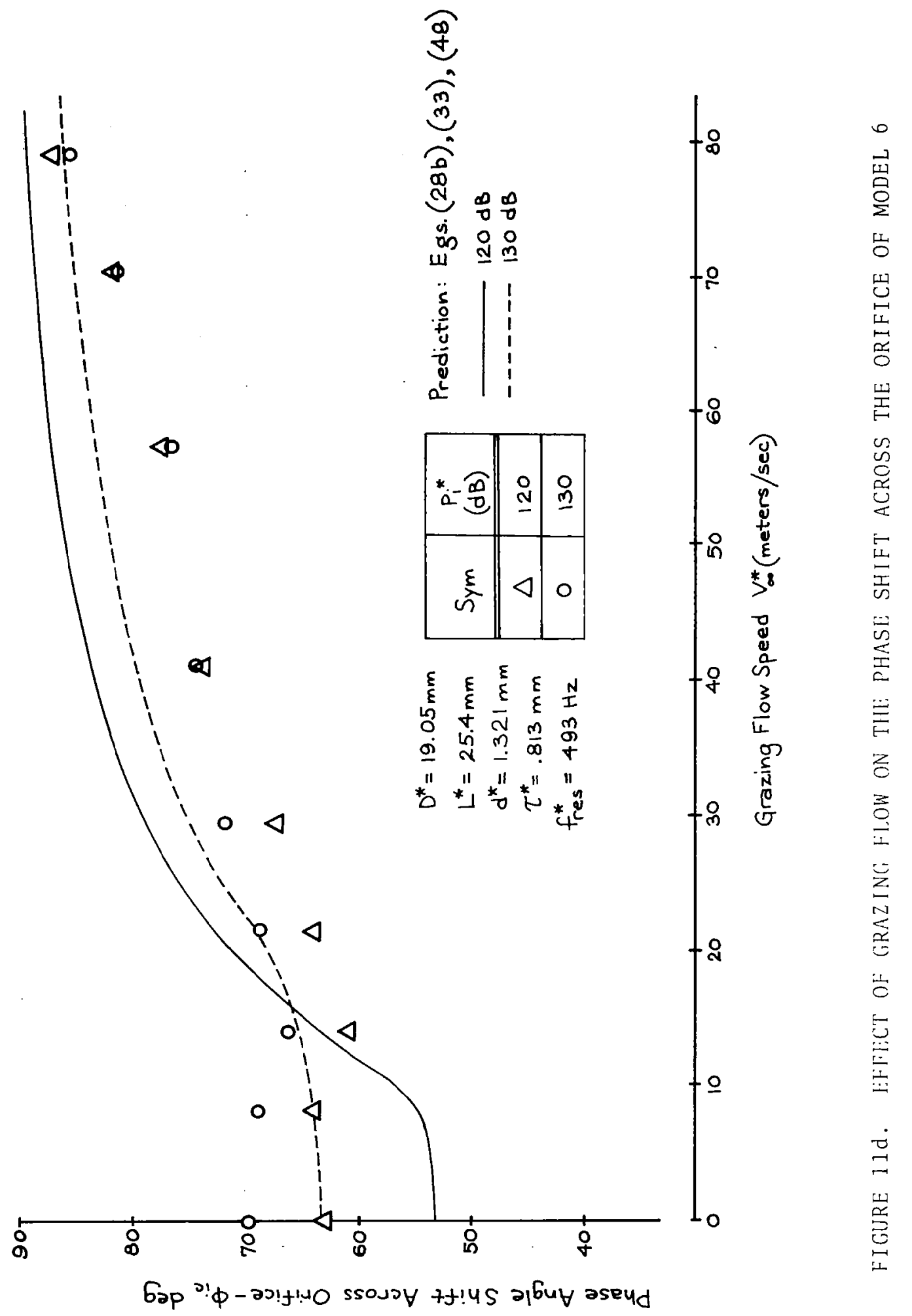




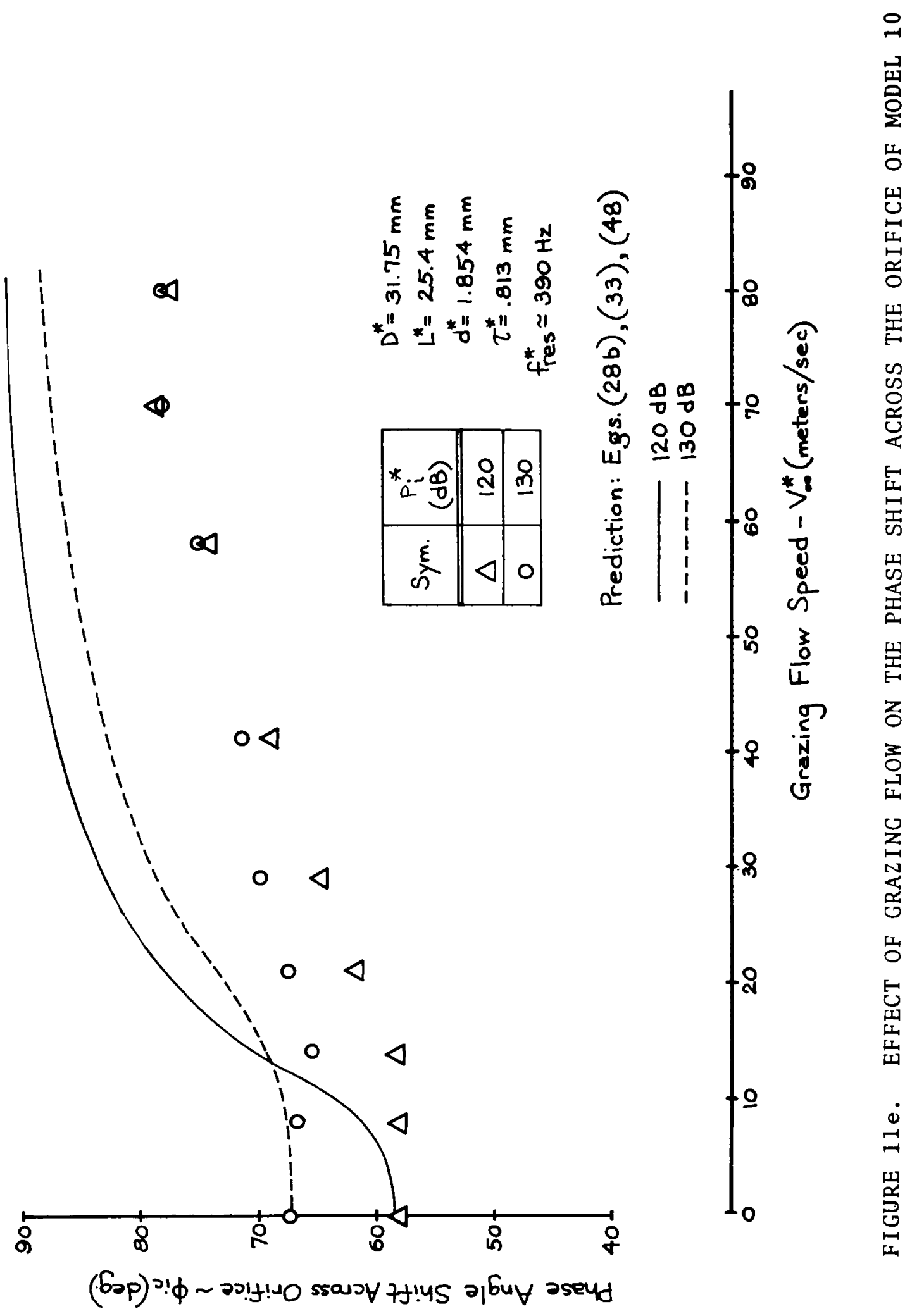




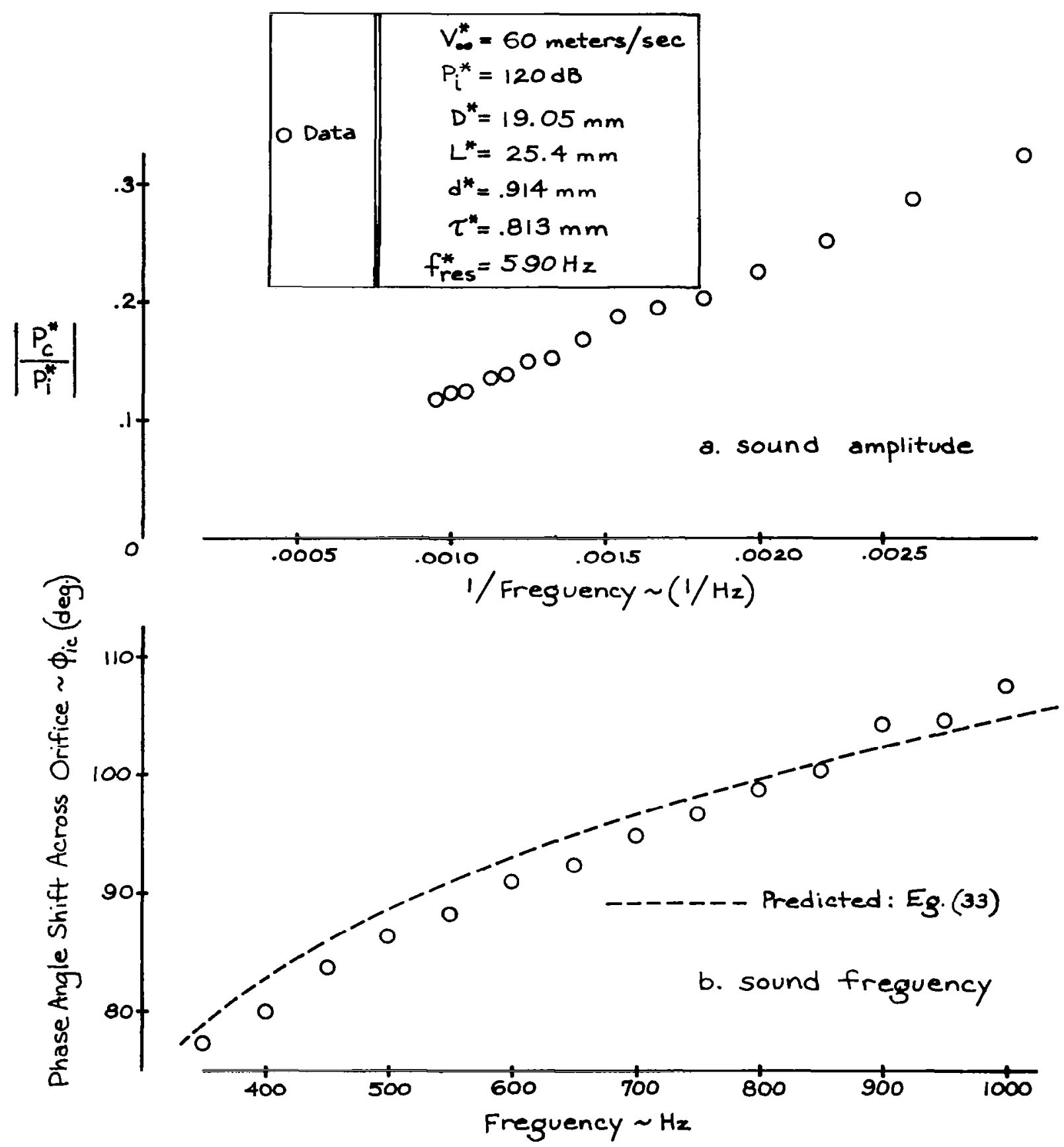

FIGURE 12. EFFECT OF FREQUENCY ON THE INCIDENT AND

CAVITY SOUND PRESSURE FIELDS OF THE

MODEL DEFINED IN APPENDIX B 


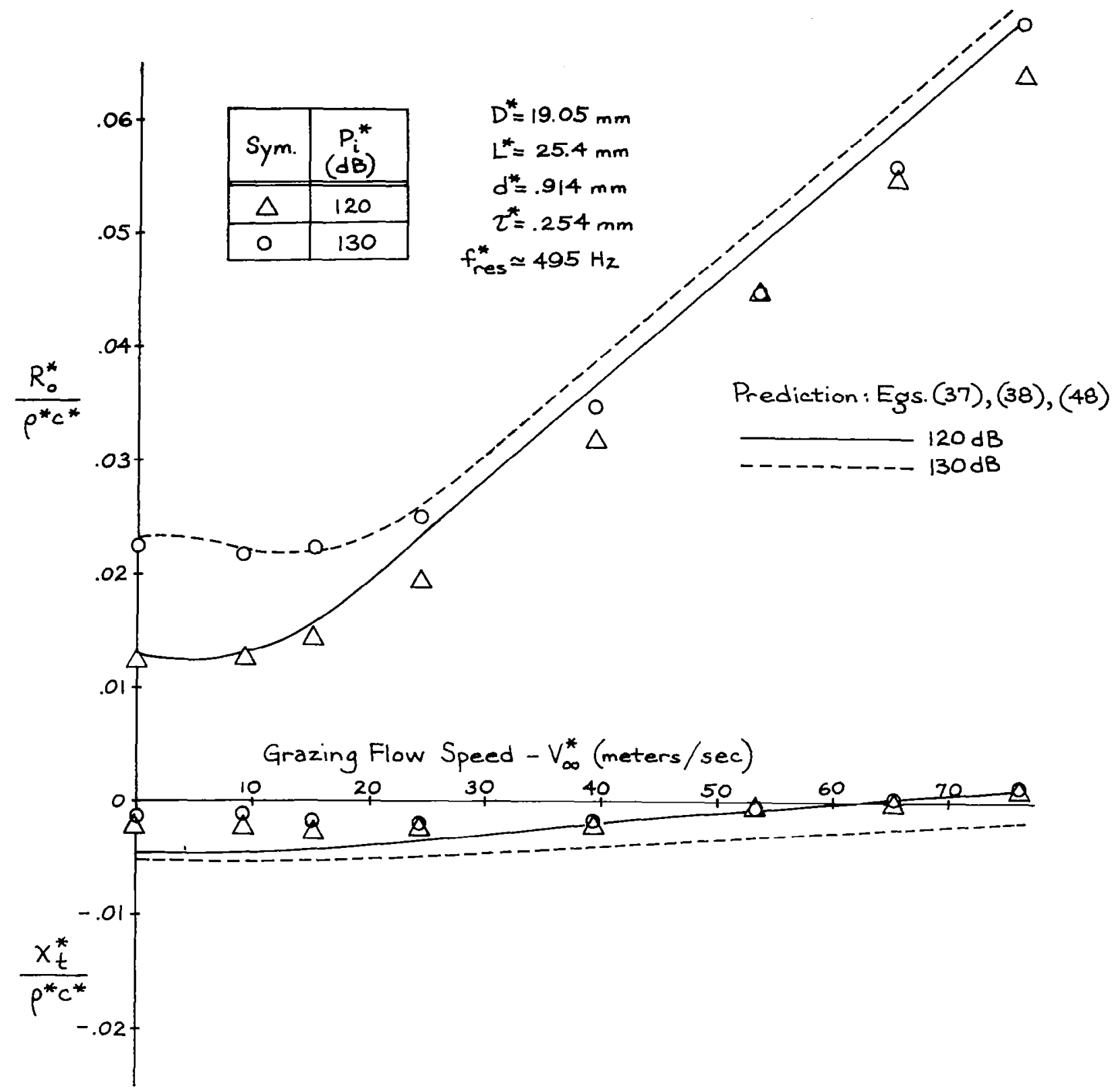

FIGURI: 13a. EFFI:CT OF GRAZING FILOW ON THLE ORIFICI: ARI:AAVERAGI:D IMPEDANCI: OF MODI:I, 2 


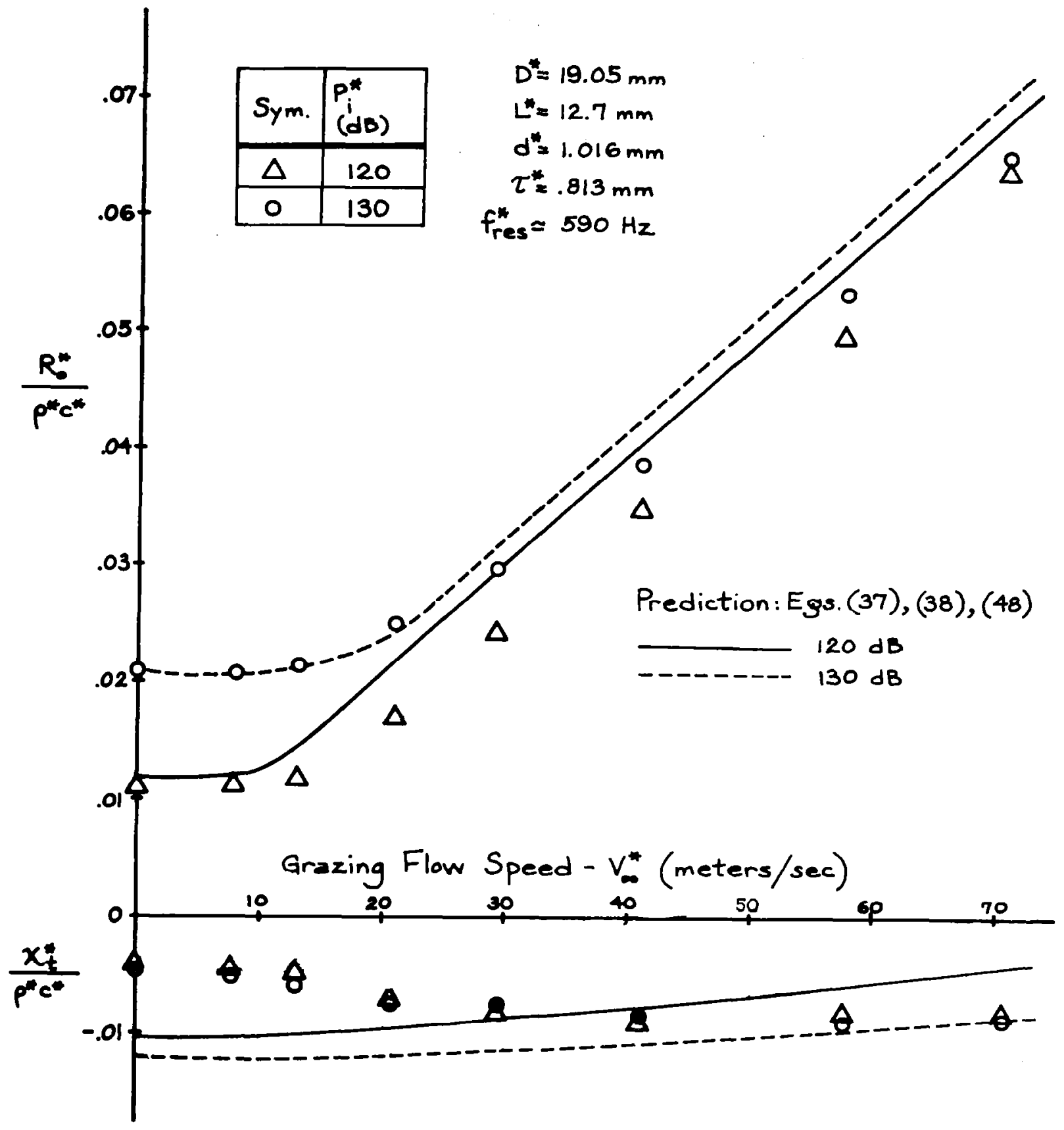

FIGURE 13b. EFFECT OF GRAZING FLOW ON THE ORIFICE AREA-AVERAGED IMPEDANCE OF MODEL 3 


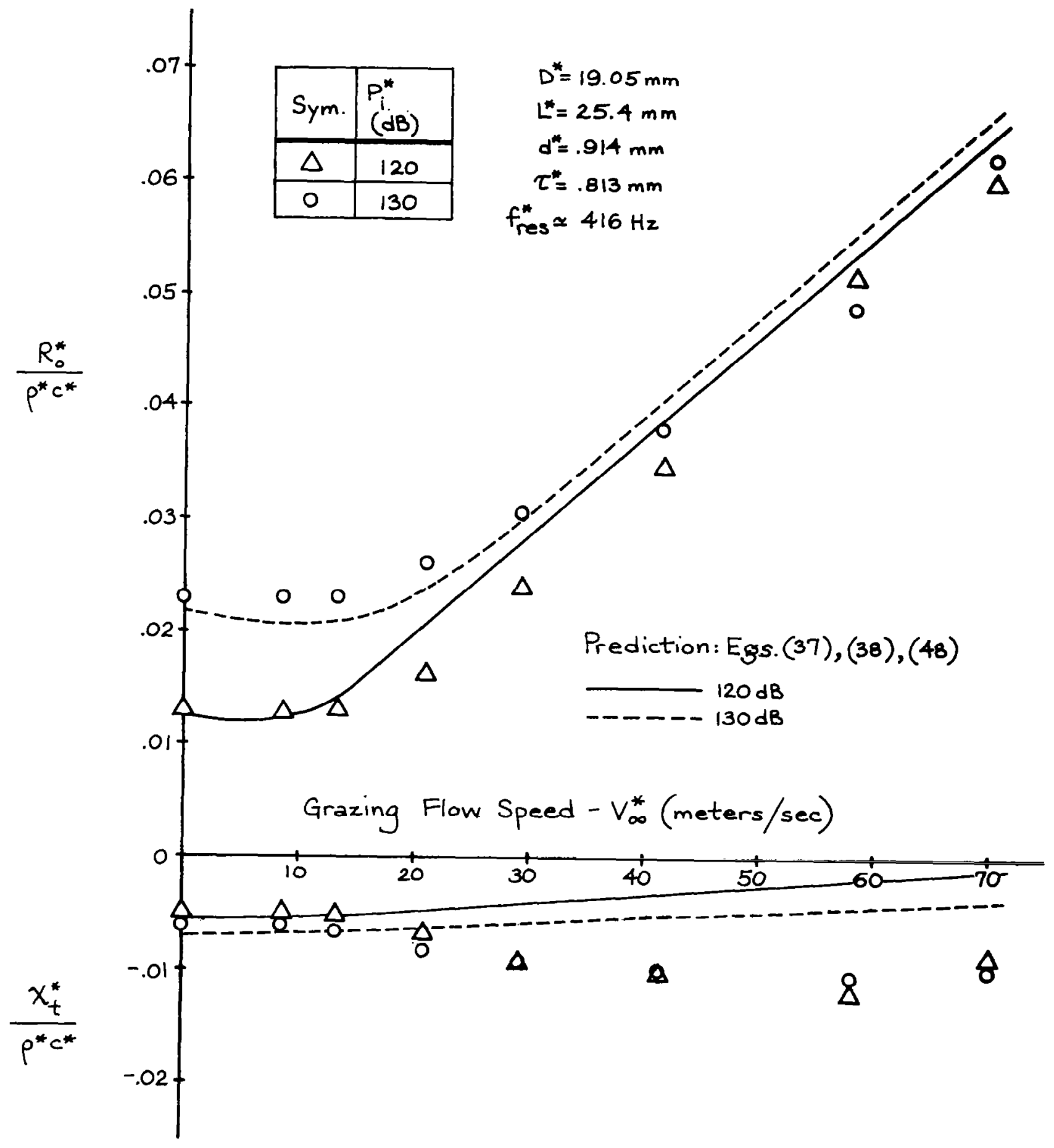

FIGURE 13C. EFFECT OF GRAZING FLOW ON THE ORIFICE AREAAVERAGED IMPEDANCE OF MODEL 4 


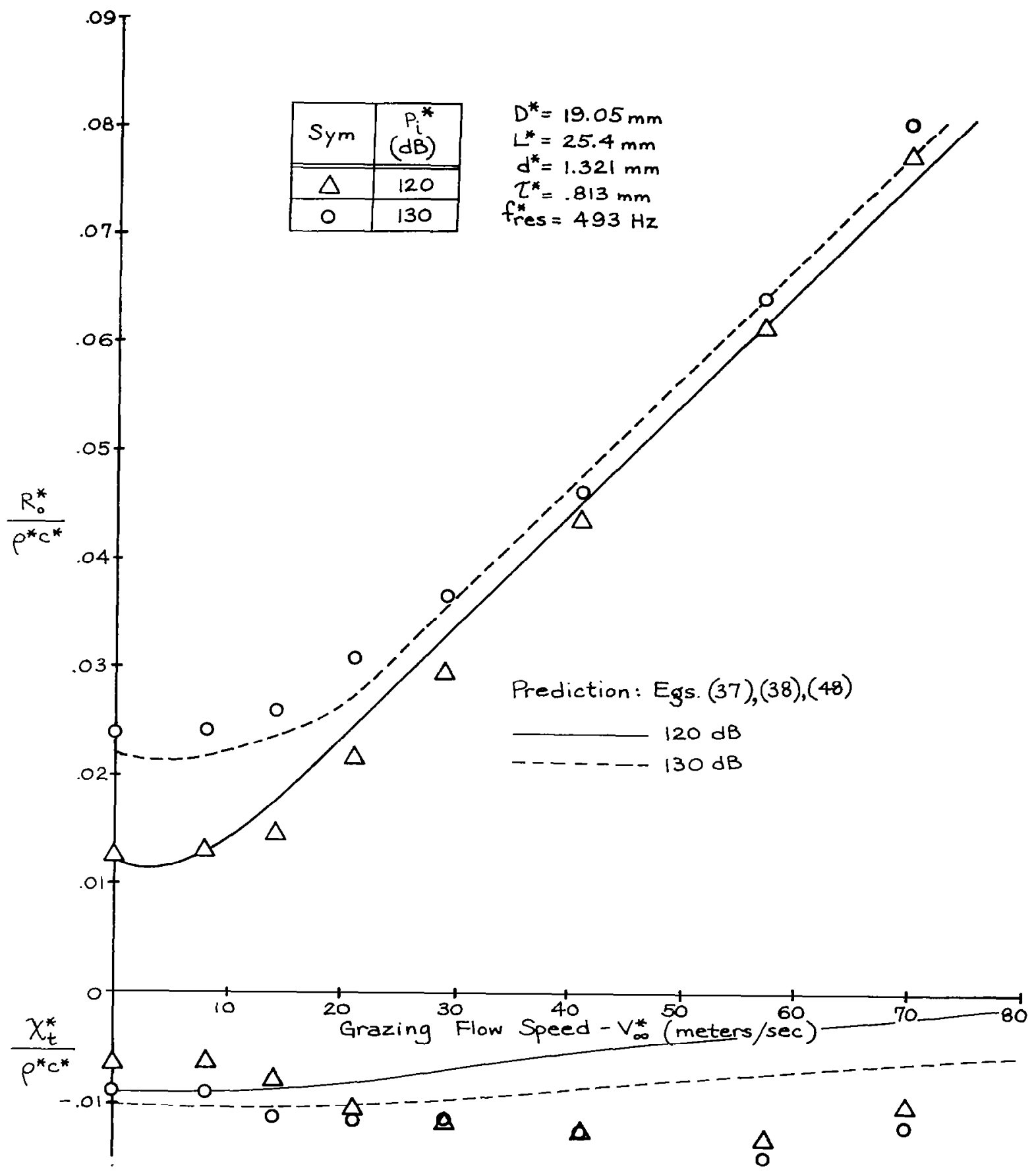

FICURI: 13d. EFFECT OF GRAZING FLOW ON THE ORIFICE AREAAVERAGED IMPEDANCE OF MODEL 6 


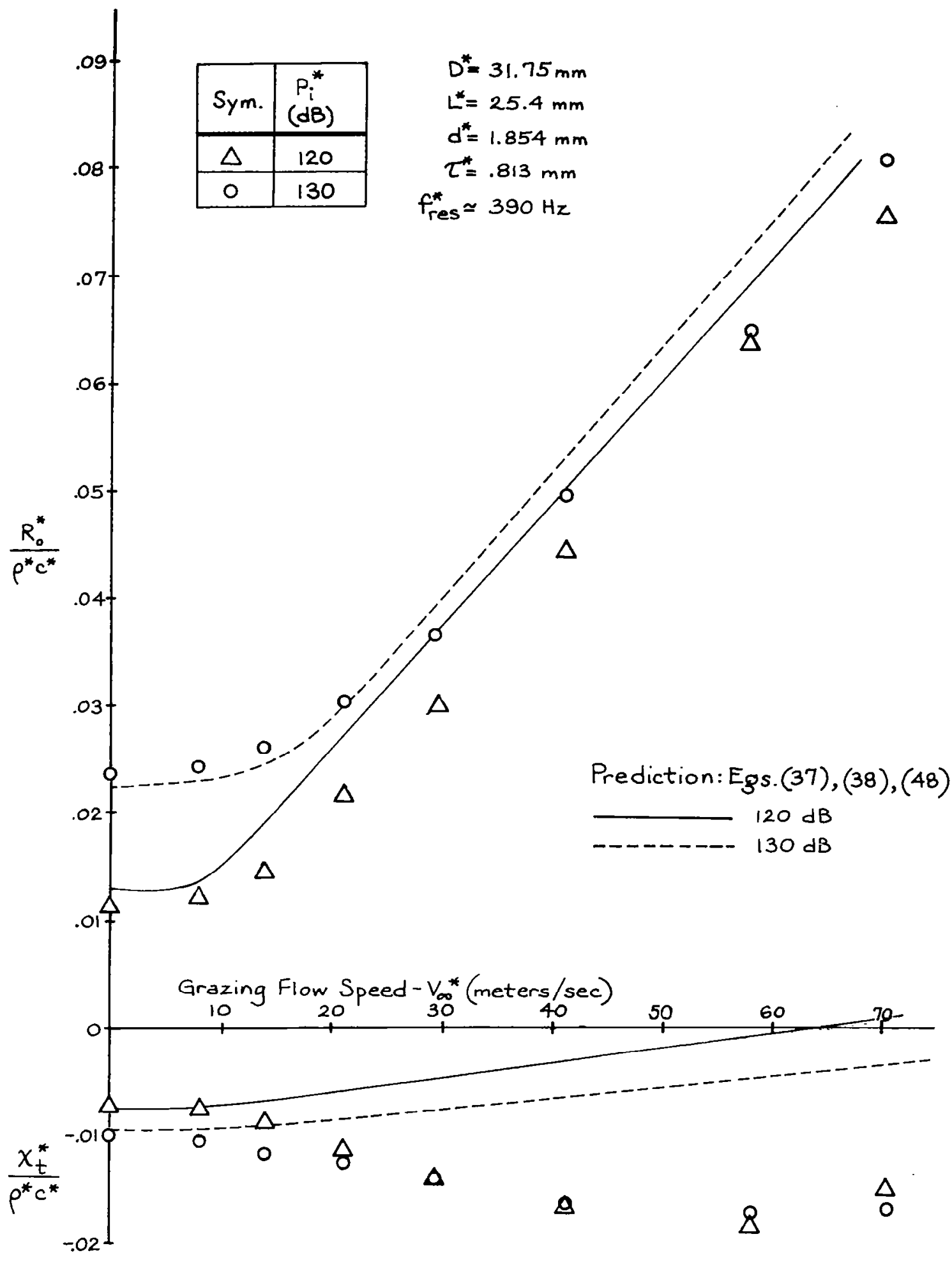

FIGURE 13e. EFFECT OF GRAZING FLOW ON THE ORIFICE AREAAVERAGED IMPEDANCE OF MODEL 10 

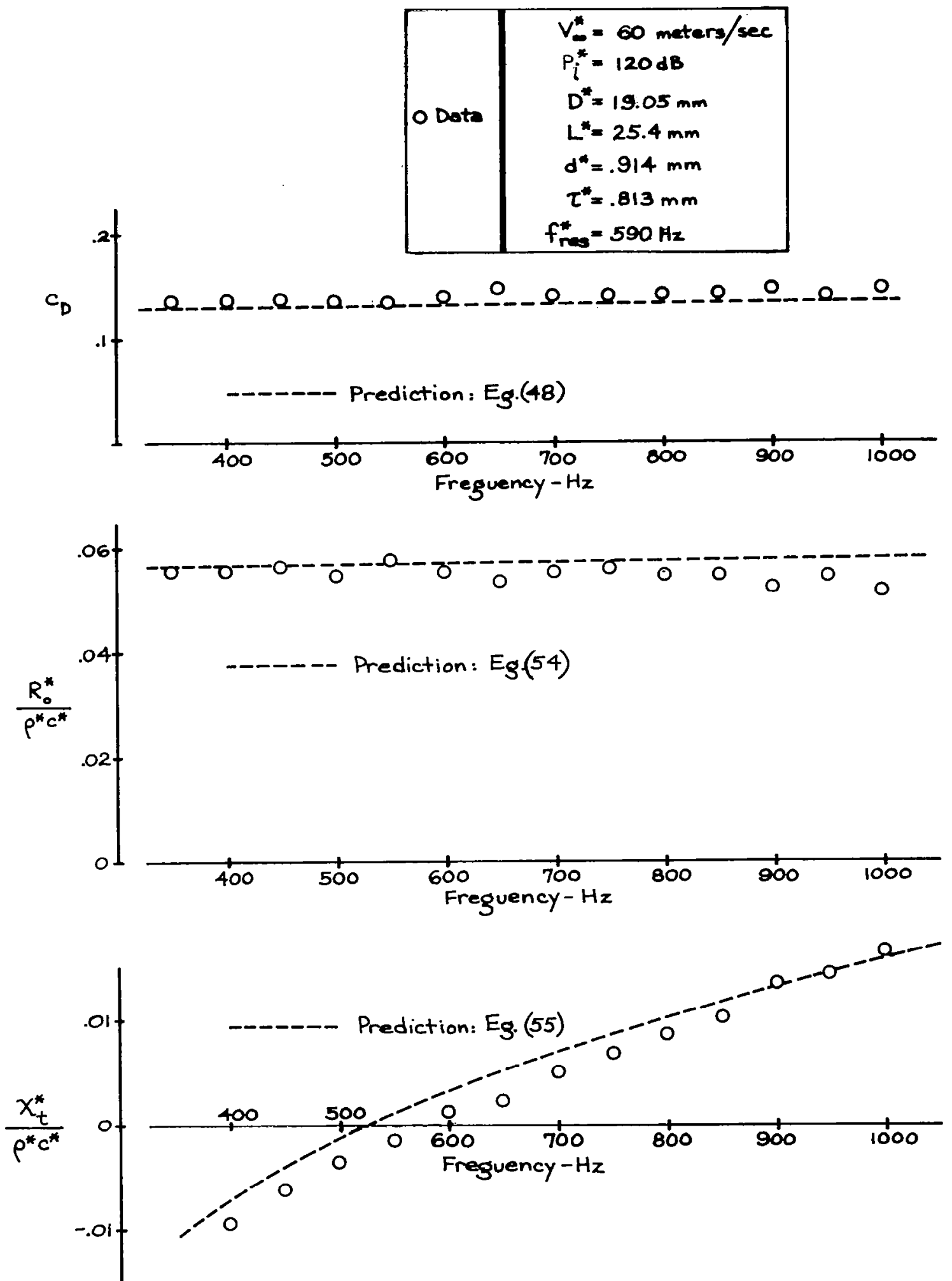

FIGURE 14. EFFECT OF FREQUENCY ON THE DISCHARGE COEFFICIENT AND ORIFICE AREA-AVERAGED IMPEDANCE OF THE MODEL DEFINED IN APPENDIX B 


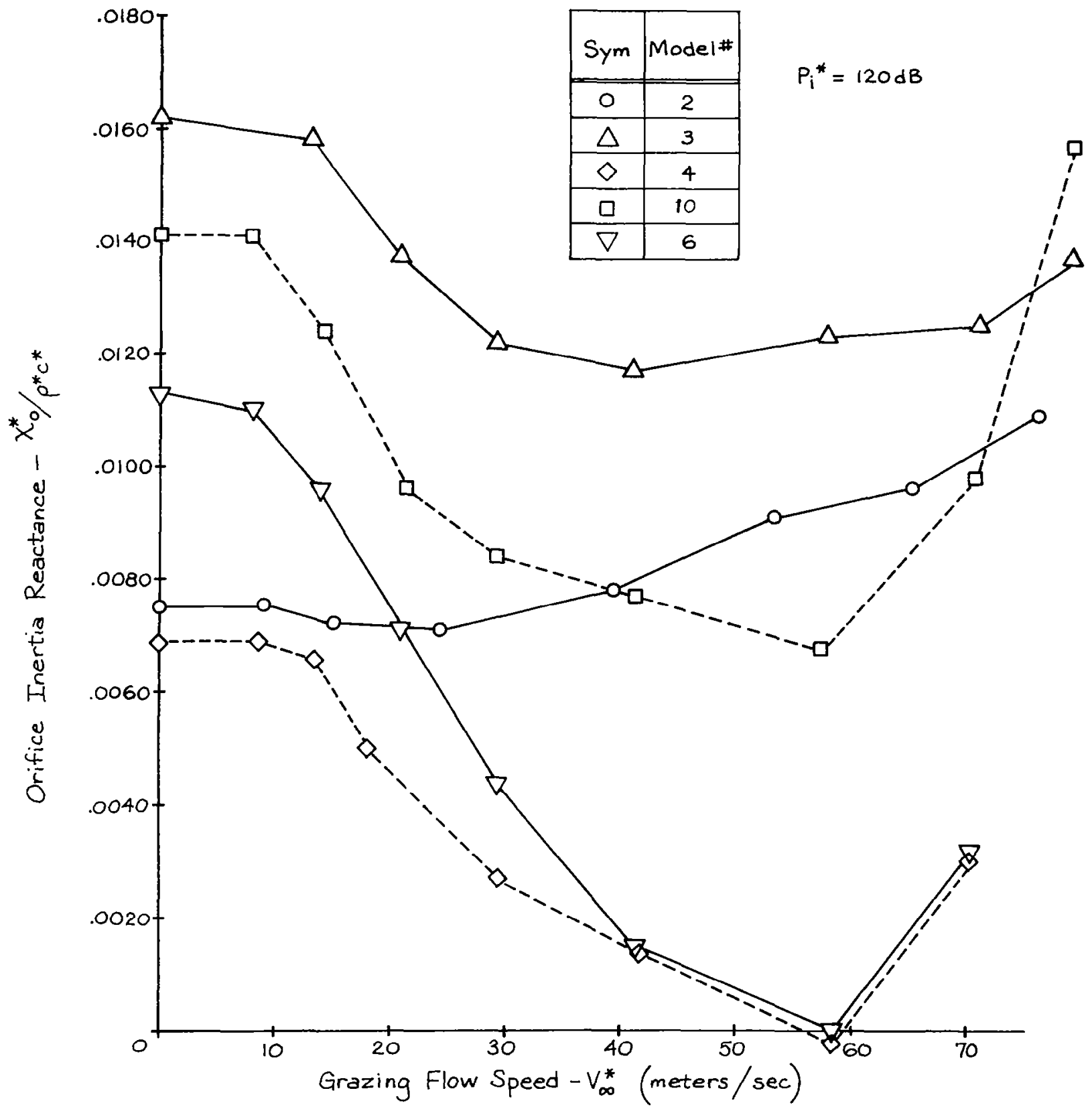

FIGURE 15a. LFFECT OF GRAZING FLOW ON THE ORIFICE INERTIAL REACTANCE OF MODELS \#2, 3, 4, 6 and 10 


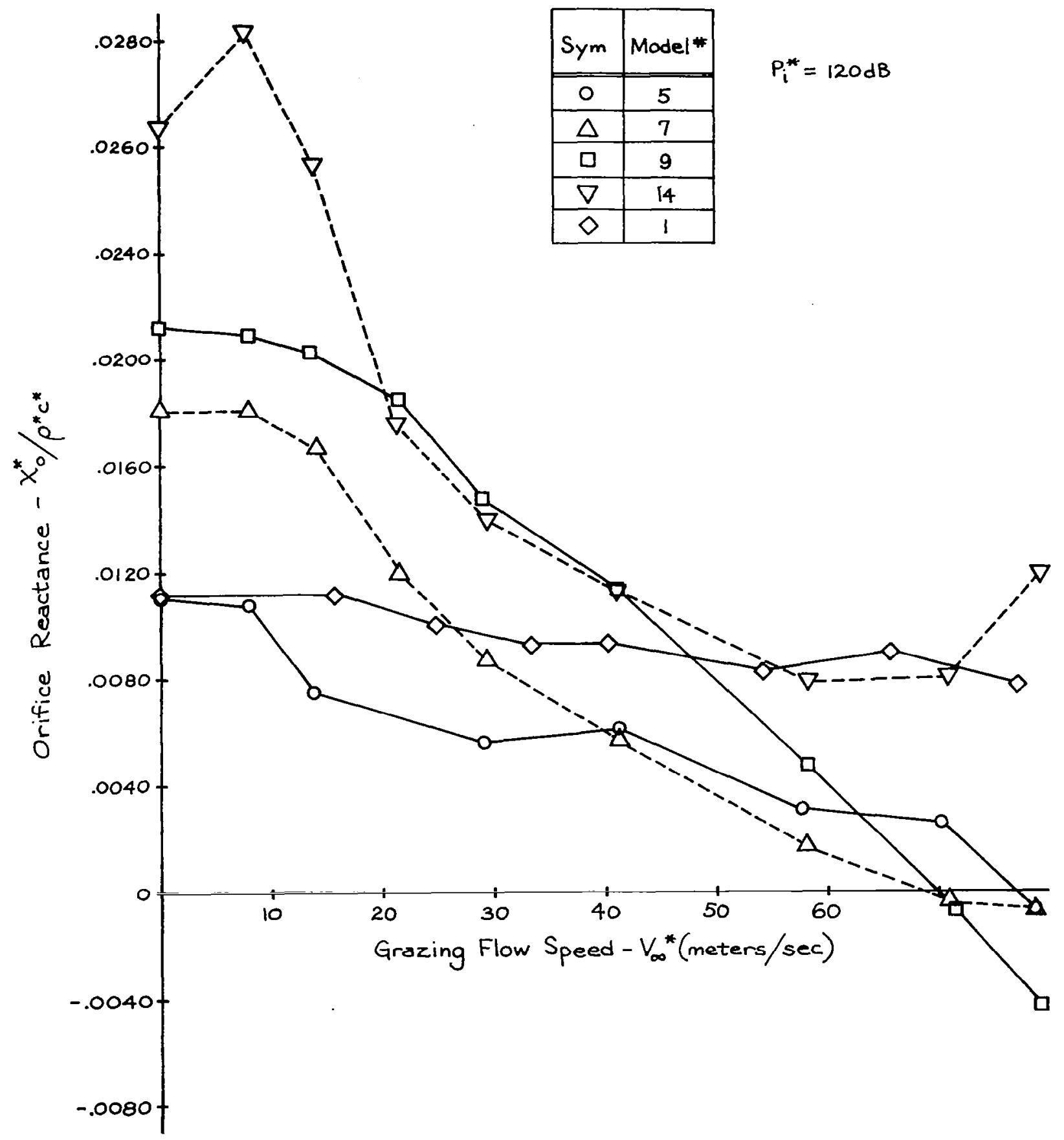

FIGURE 15b. EFFECT OF GRAZING FLOW ON THE ORIFICE INERTIA REACTANCE OF MODELS \# $1,5,7,9$ and 14 


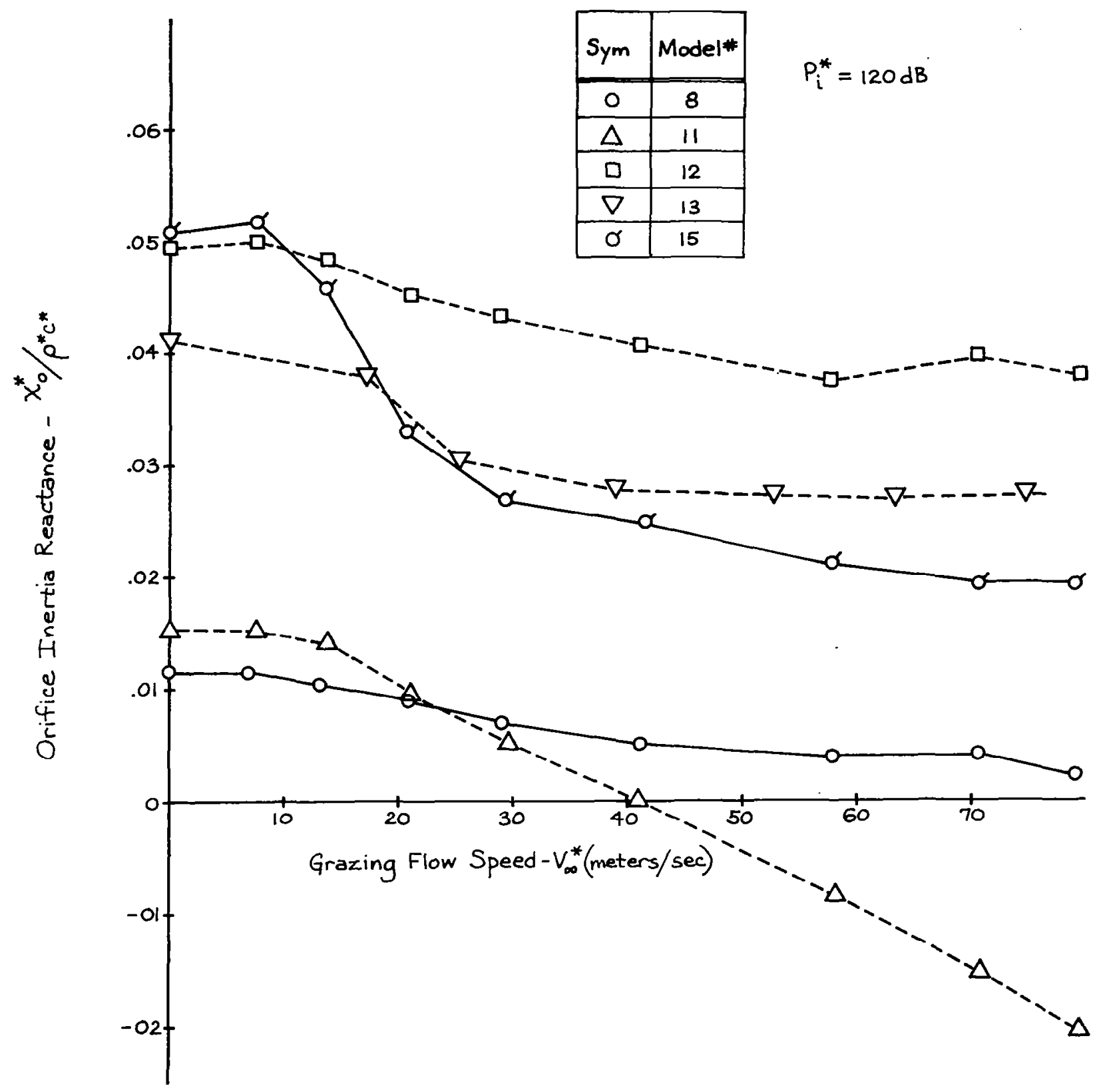

FIGURE 15C. EFFECT OF GRAZING FLOW ON THE ORIFICE INERTIA REACTANCE OF MODELS \# $8,11,12,13$ and 15 


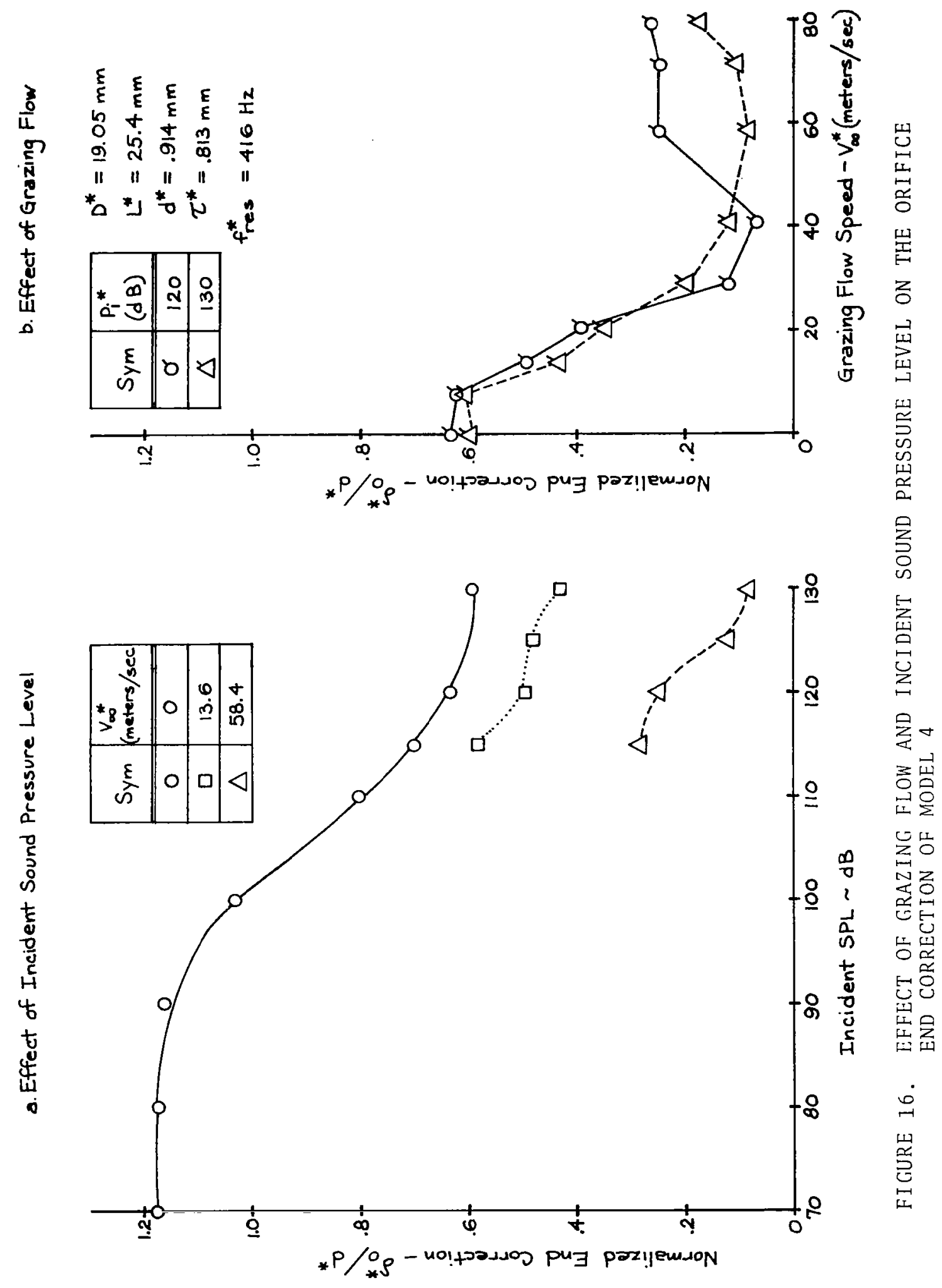




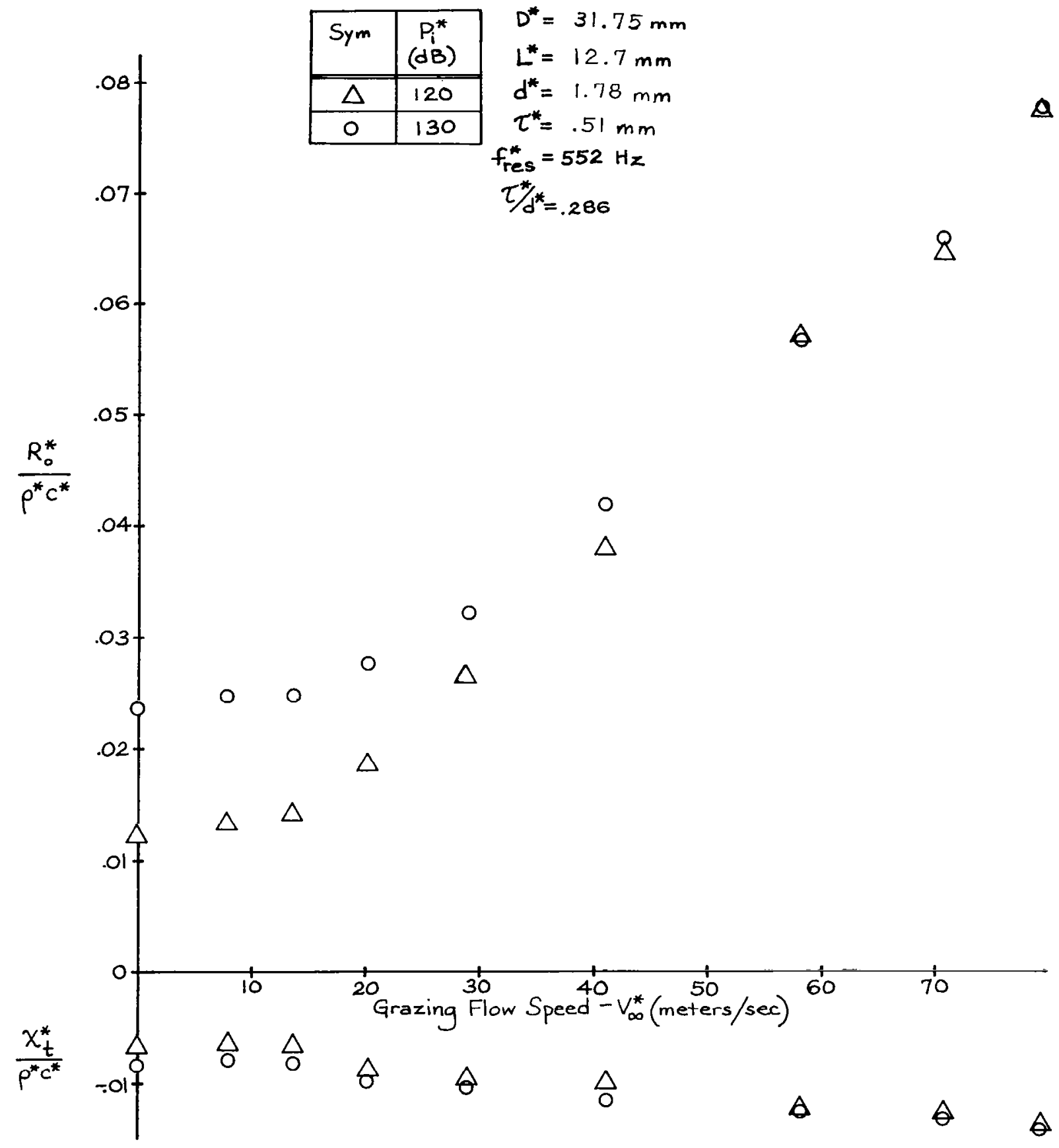

FIGURE $17 \mathrm{a}$. EFFECT OF GRAZING FLOW ON THE ORIFICE AREAAVERAGED IMPEDANCE ON THE $\tau * / \mathrm{d} *=0.286$ CONFI GURATI ON 


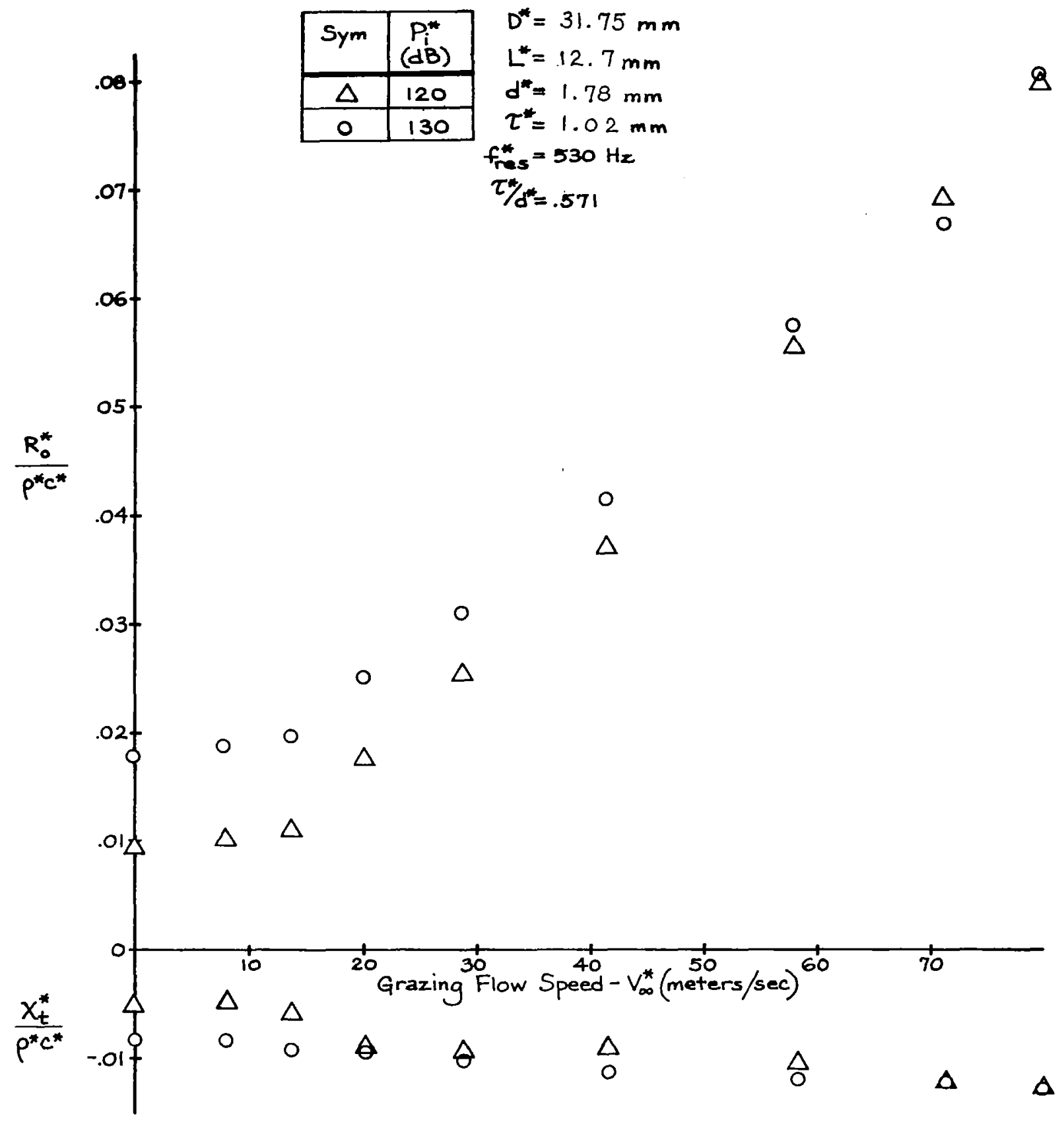

FIGURE $17 \mathrm{~b}$. EFFECT OF GRAZING FLOW ON THE ORIFICE AREAAVERAGED IMPEDANCE ON THE $\mathrm{T}^{*} / \mathrm{d}^{*}=0.571$ CONFI GURATI ON 


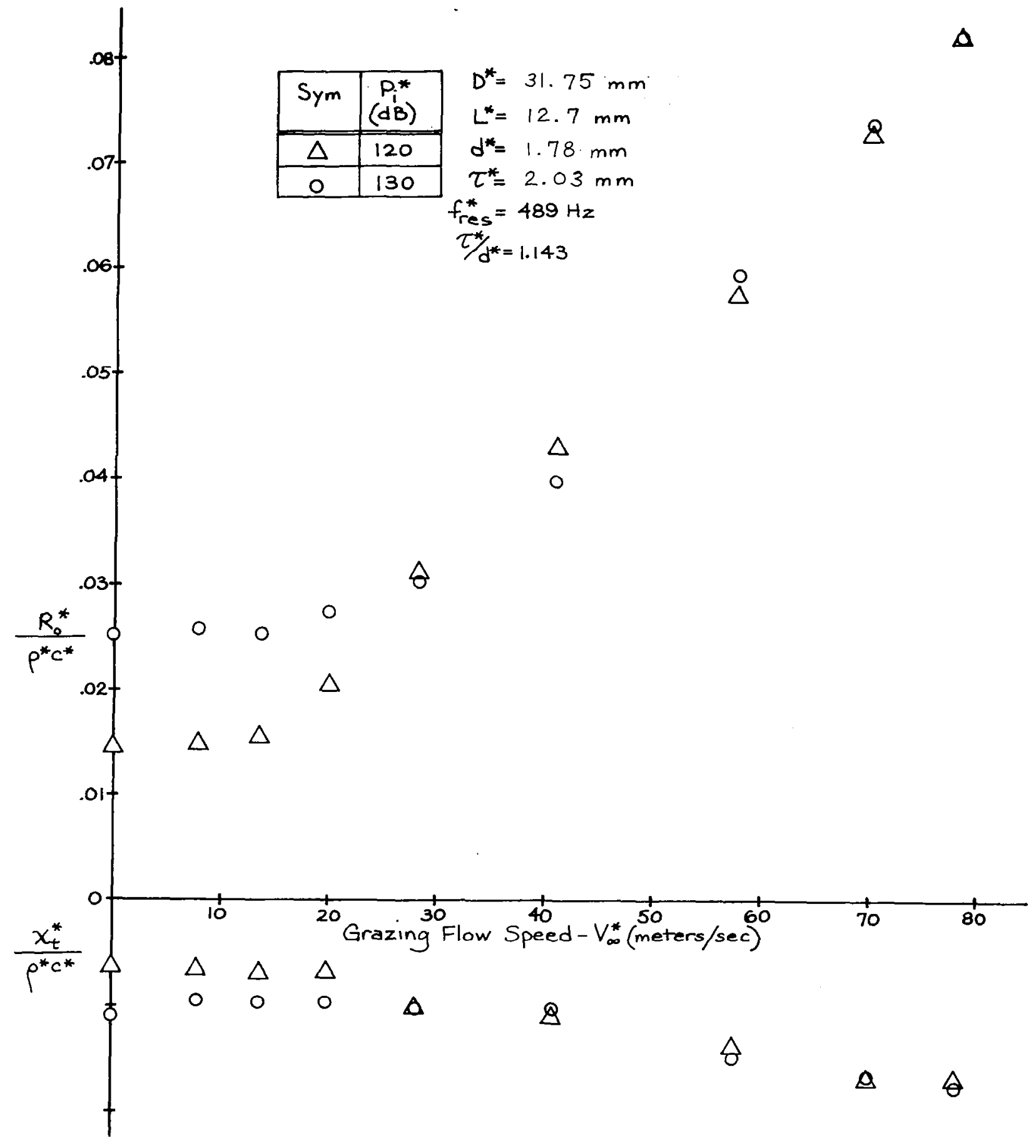

FIGURE $17 \mathrm{c}$. EFFECT OF GRAZING FLOW ON THE ORIFICE AREAAVERAGED IMPEDANCE ON THE $\tau * / \mathrm{d} *=1.143$ CONF I GURATI I N 


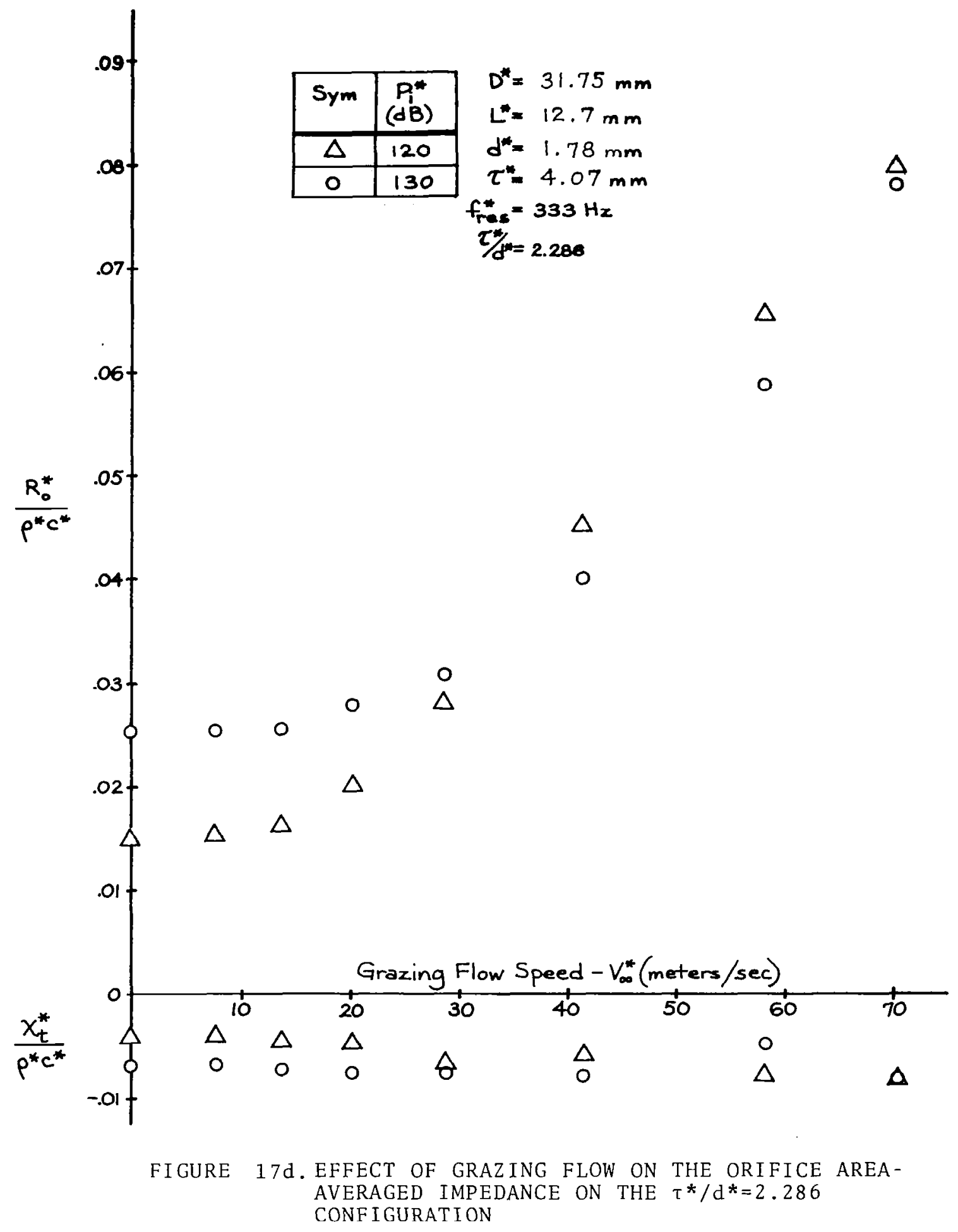




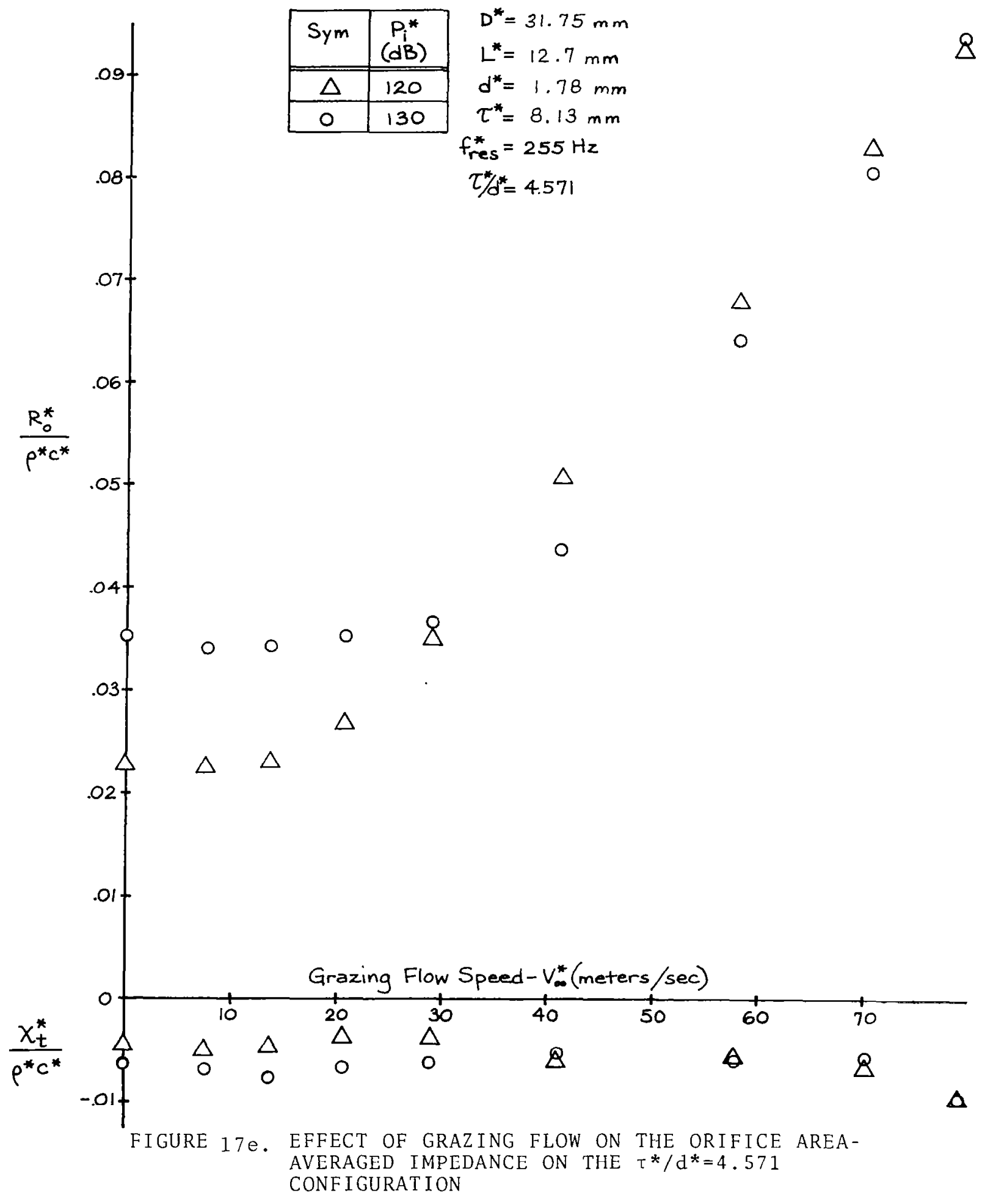



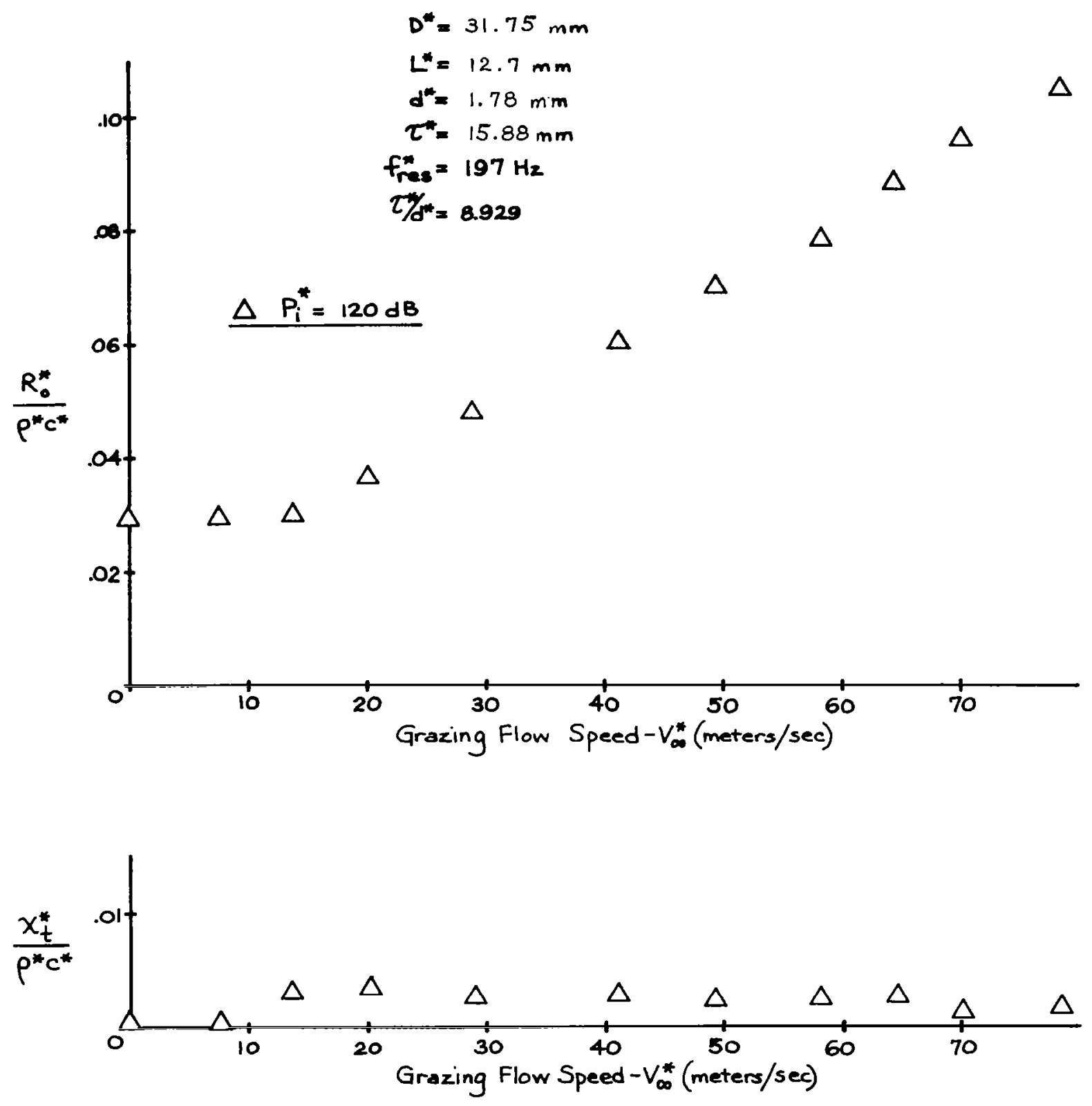

FIGURE 17f. EFFECT OF GRAZING FLOW ON THE ORIFICE AREAAVERAGED IMPEDANCE ON THE $\tau * / d^{*}=8.929$ CONFIGURATION 


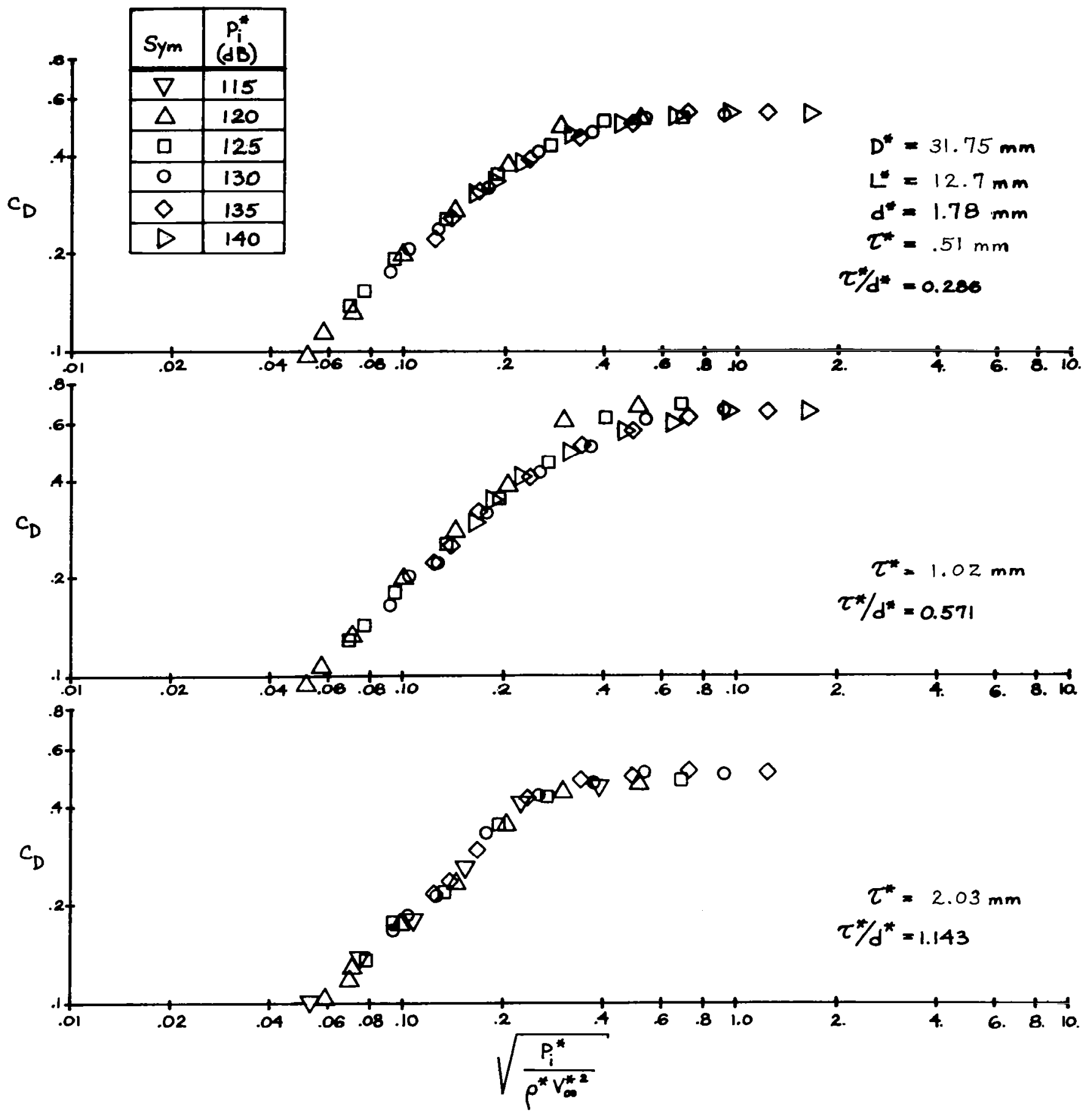

FIGURE 18a. CORRELATION OF THICK ORIFICE GRAZING FLOW SOUND DATA

IN TERMS OF DISCHARGE COEFFICIENT FOR $\tau * / \mathrm{d}^{*}=0.286,0.571$

AND 1.143 

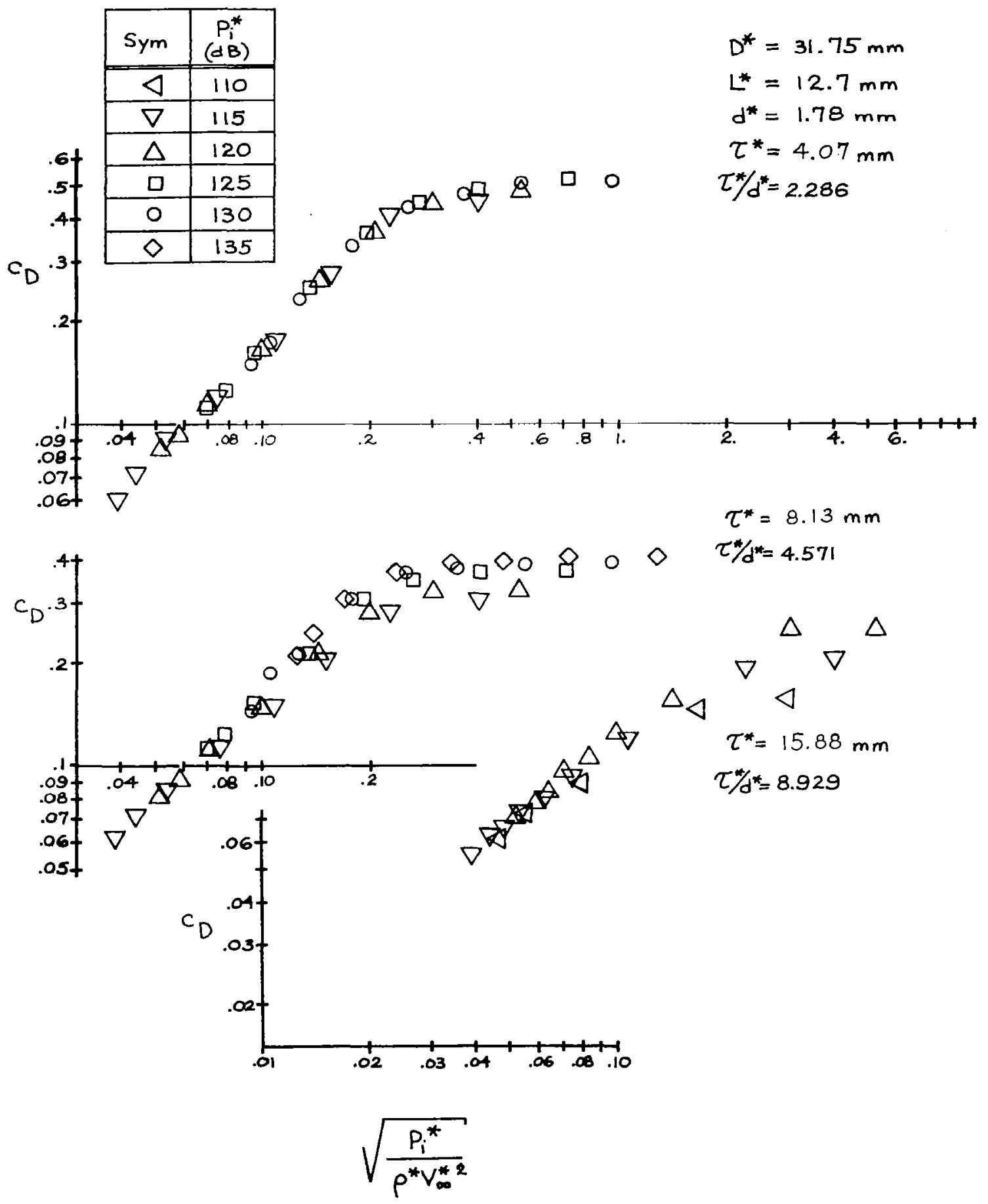

FIGURE 18b. CORRELATION OF THICK ORIFICE GRAZING FLOW SOUND DATA IN TERMS OF DISCHARGE COEFFICIENT FOR $\tau * / \mathrm{d}^{*}=i 2.286$, $4 \% 571$ and 8.929 

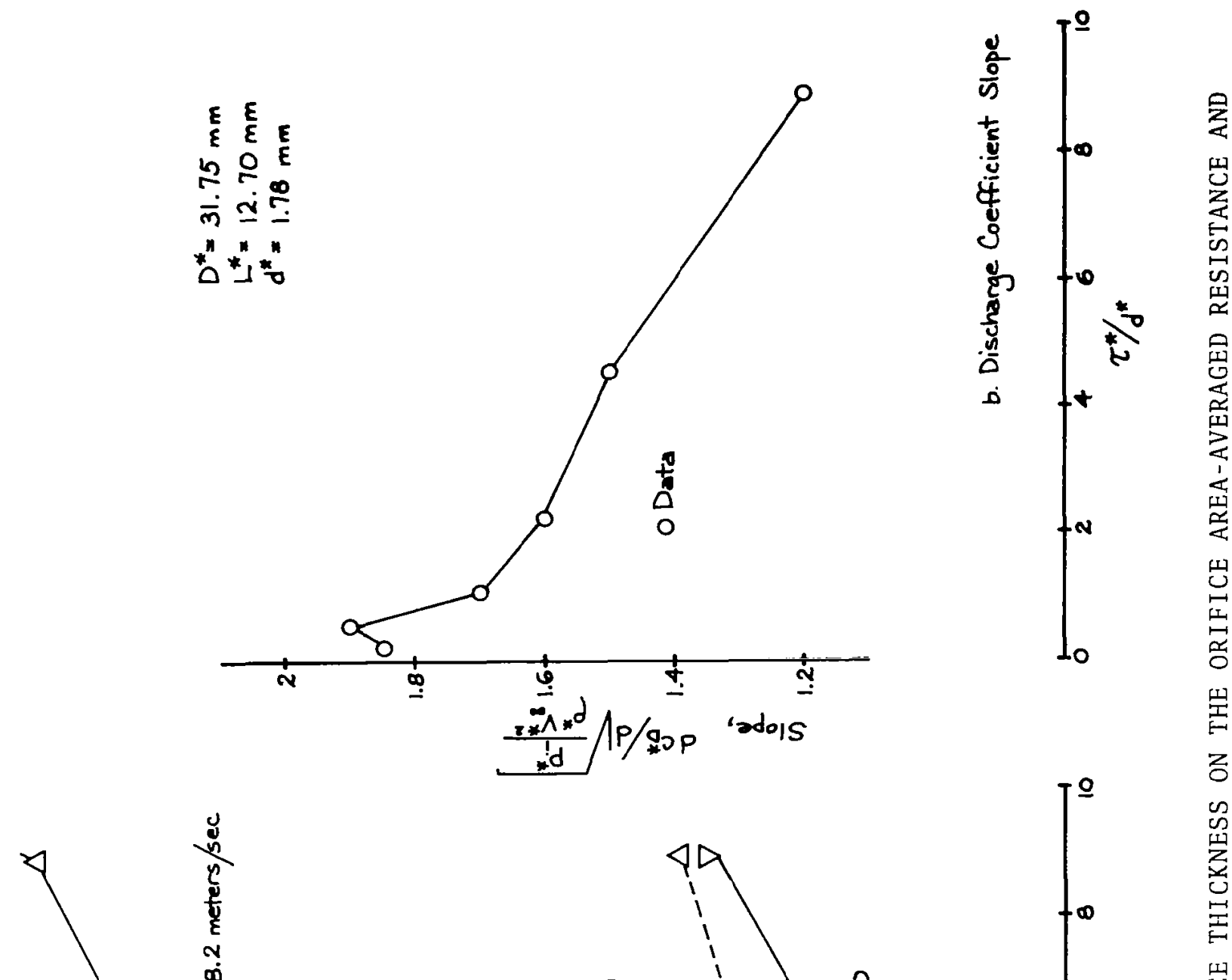

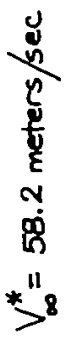
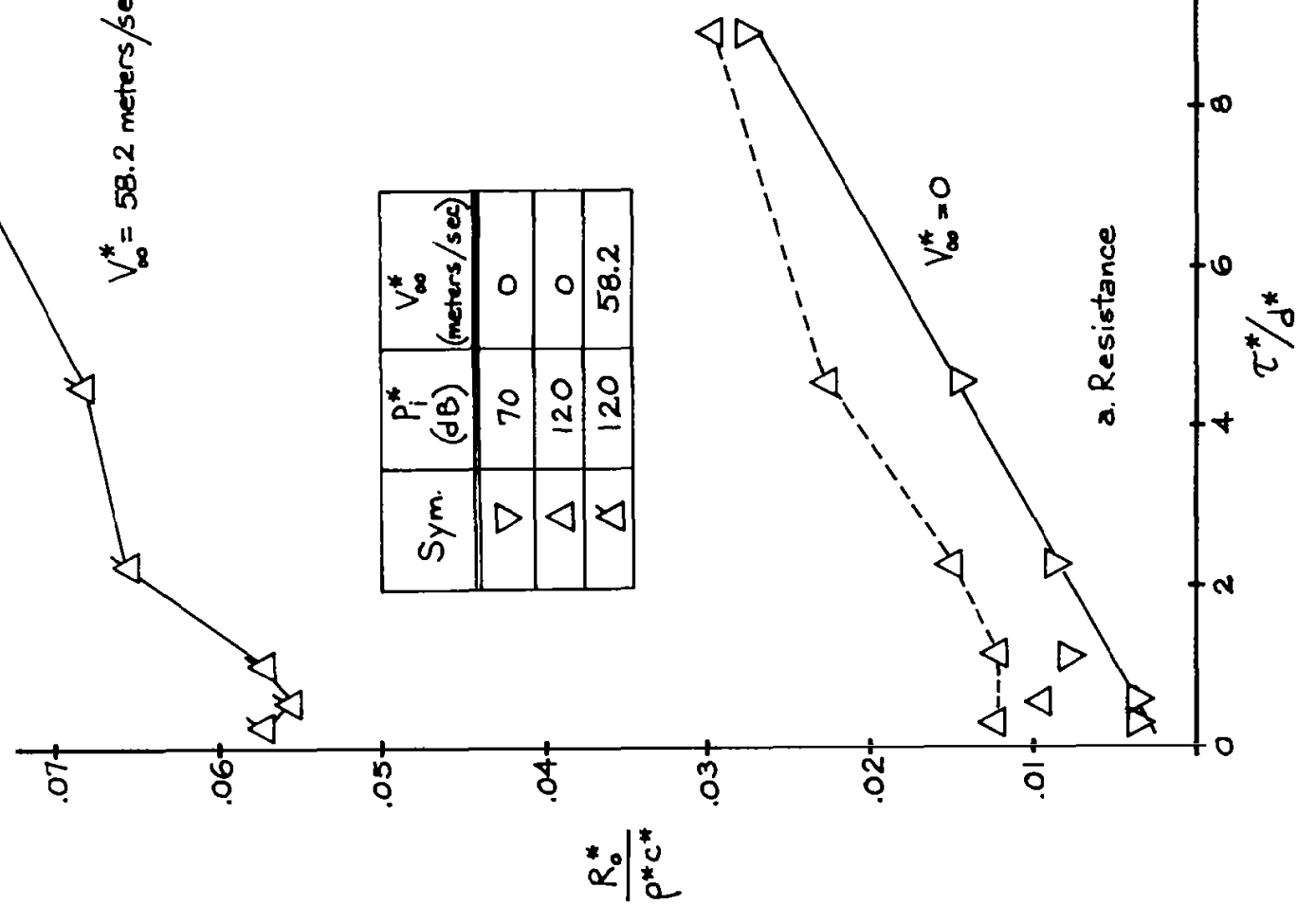

荘

z

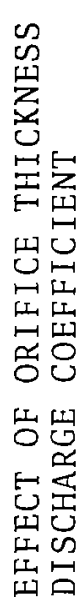

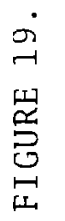




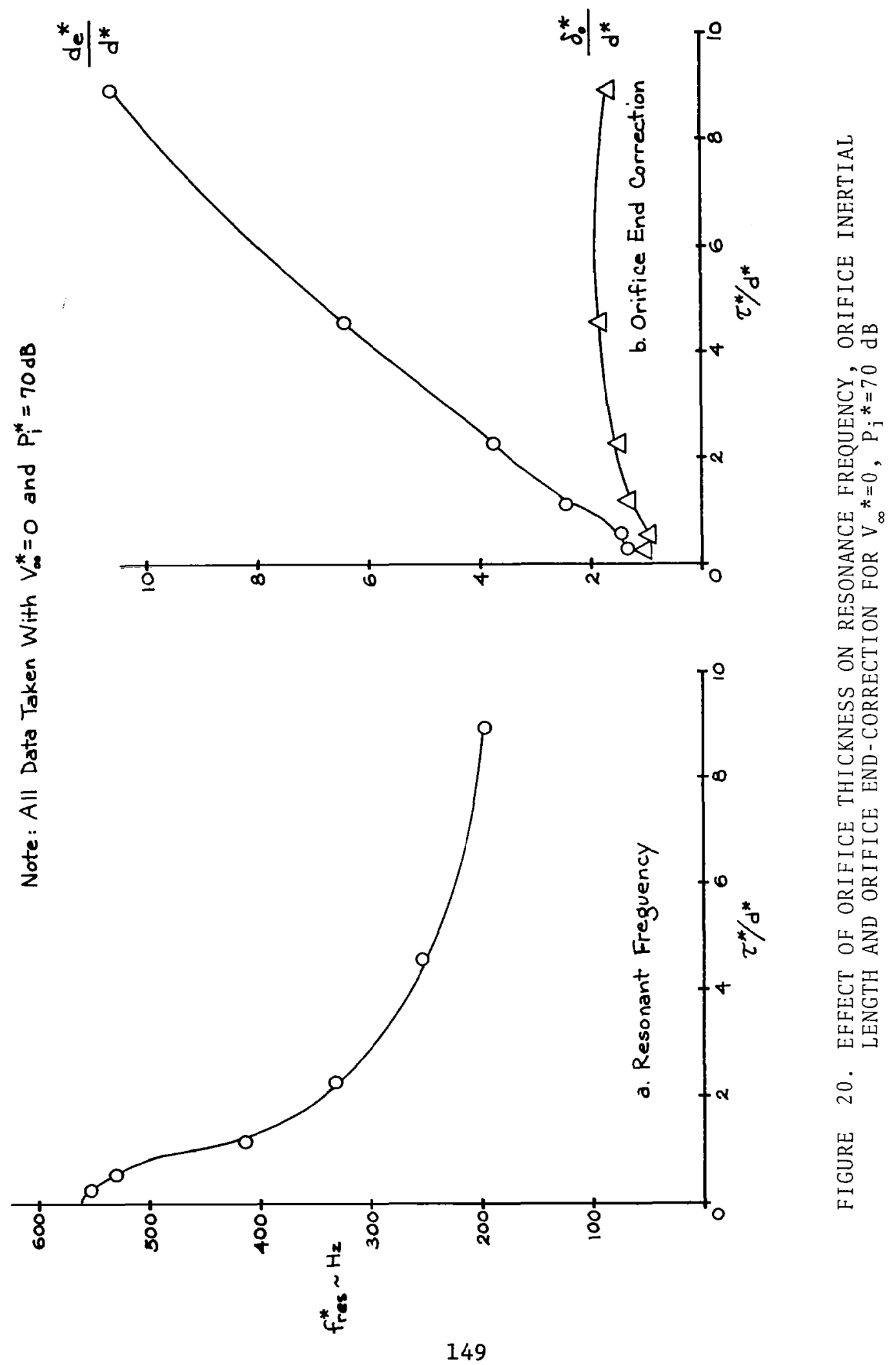




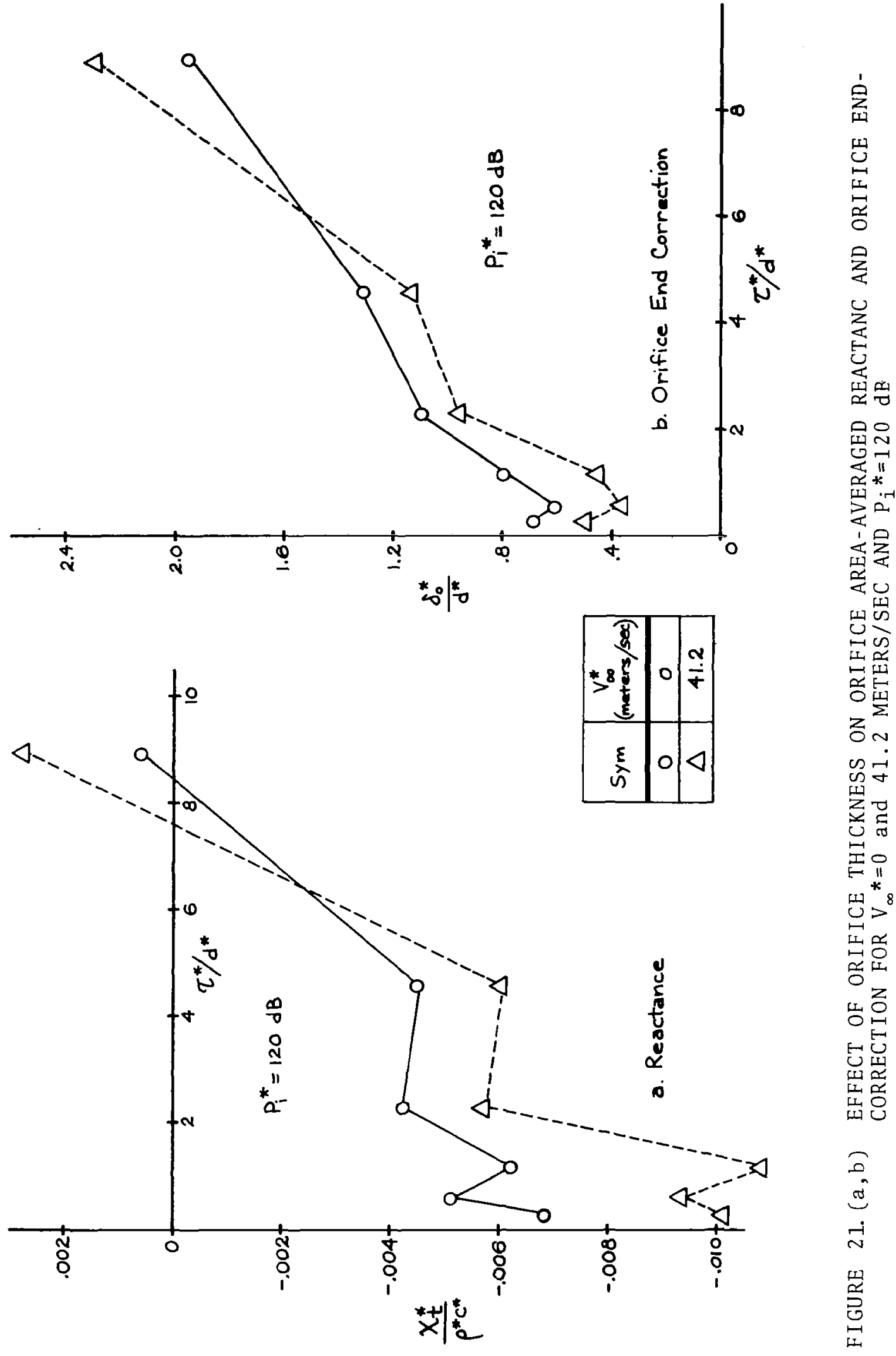




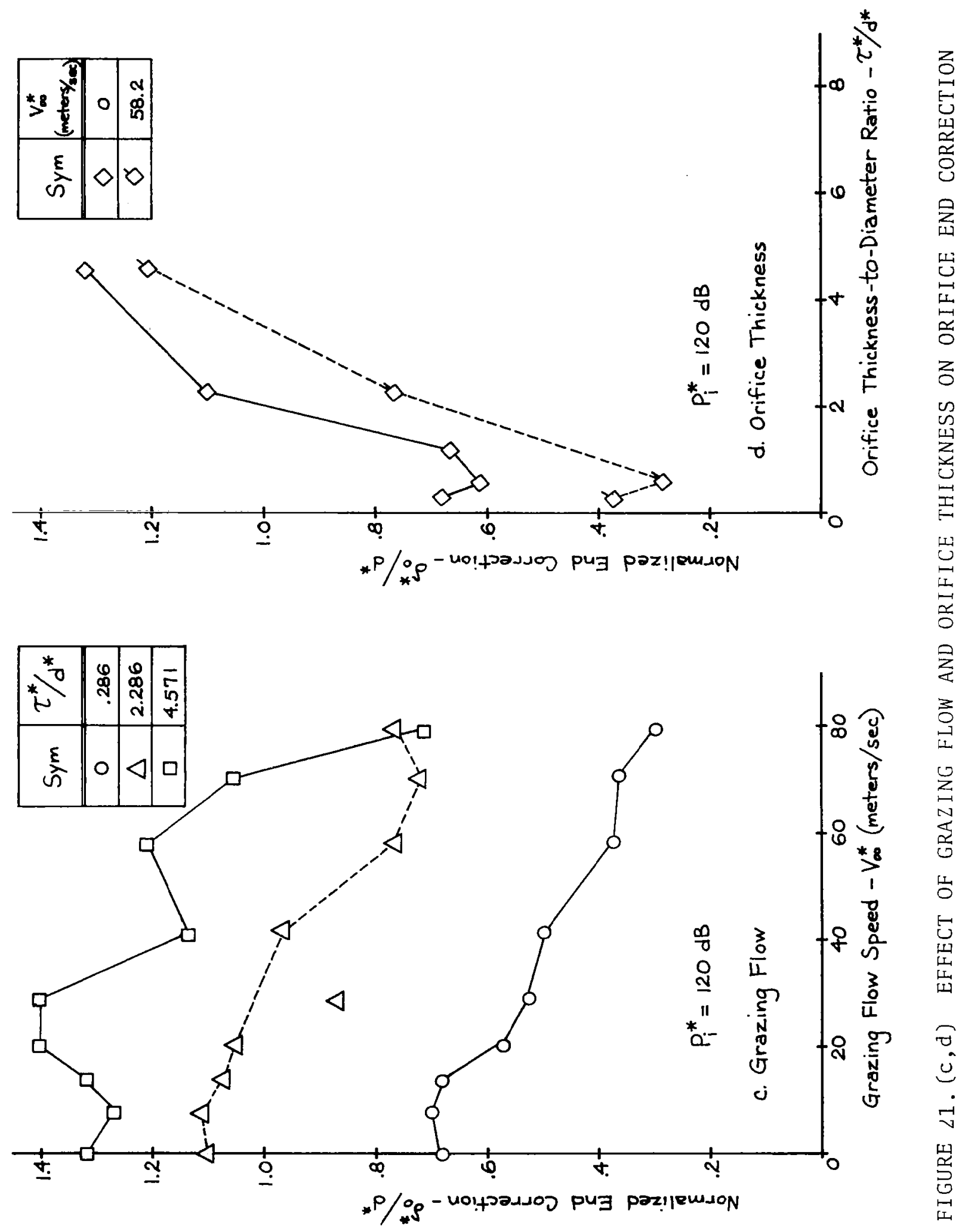




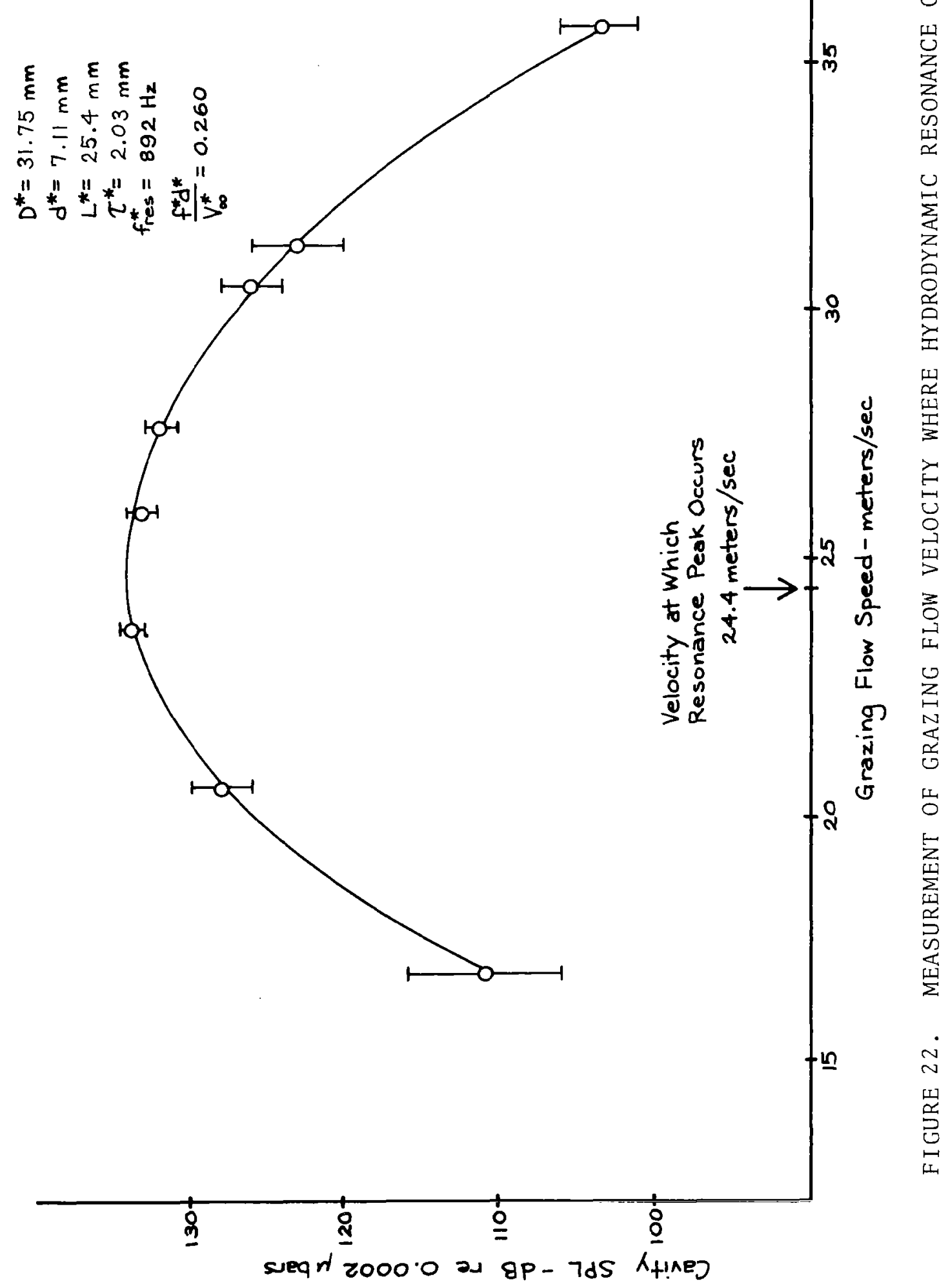




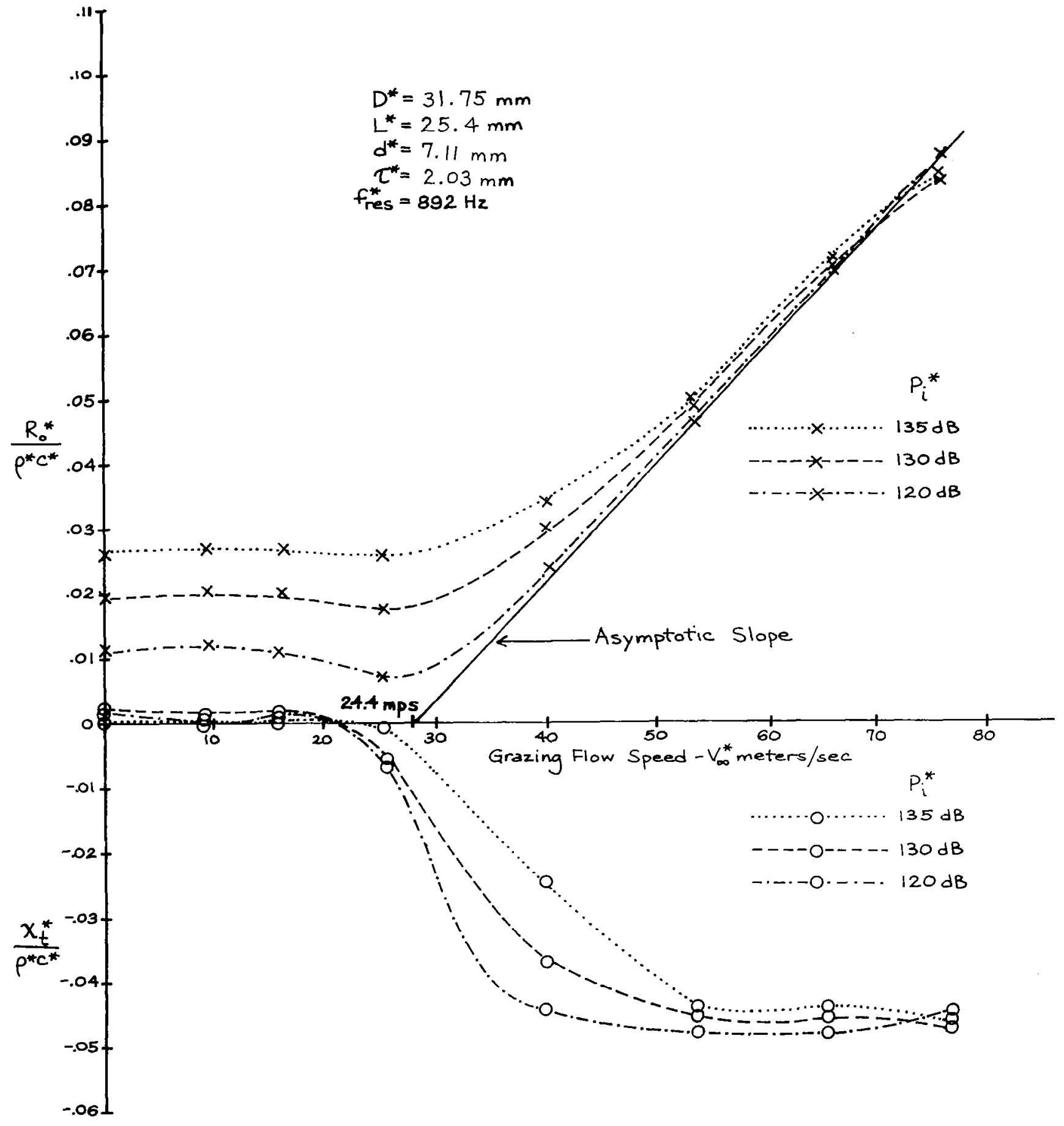

FIGURE 23a. CORRELATION BETWEEN MEASURED AND PREDICTID RESONANT GRAZING FLOW SPEED OF MODEL 1 


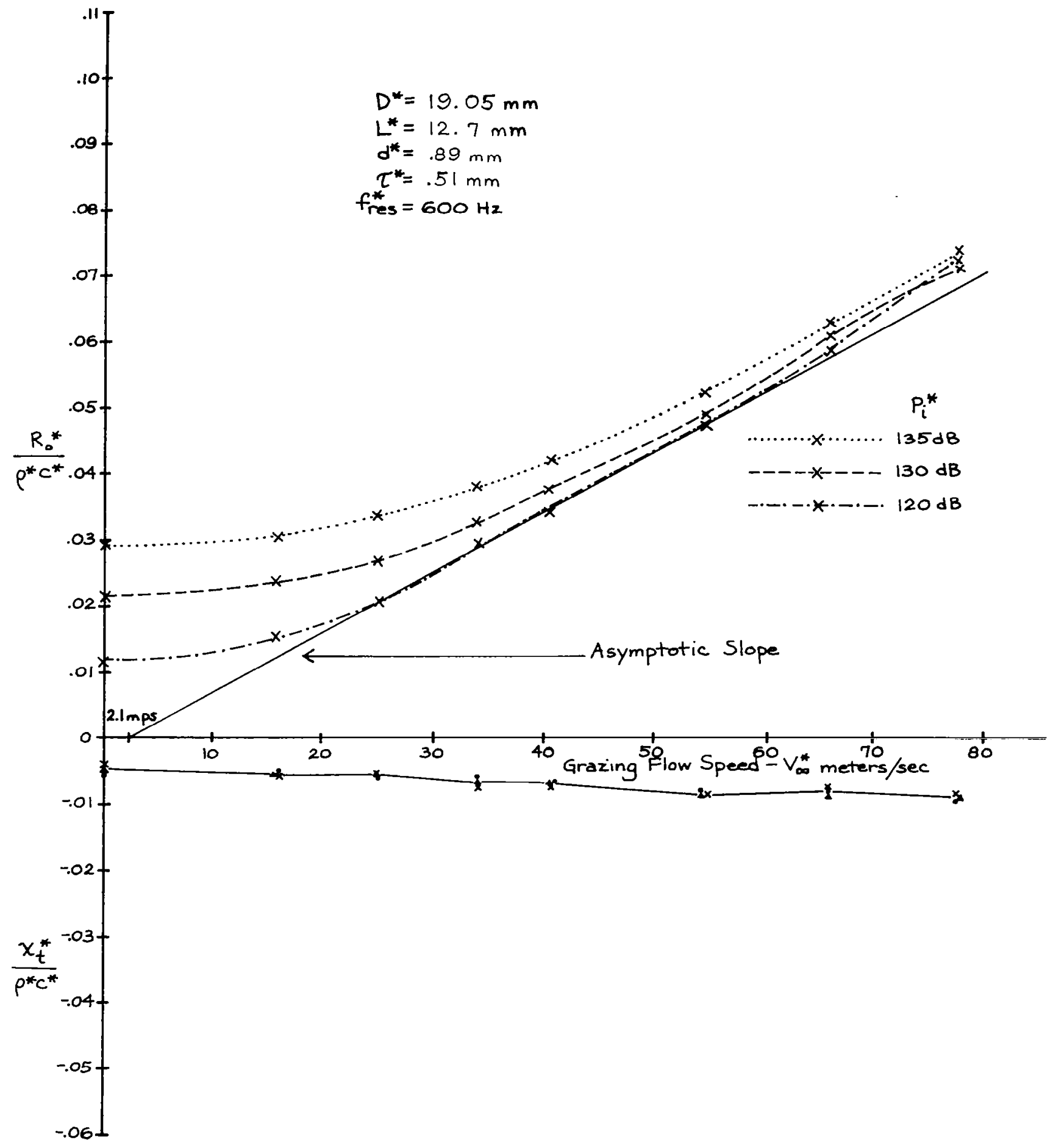

FIGURE 23b. CORRELATION BETWEEN MEASURED AND PREDICTED RESONANT GRAZING FLOW SPEED OF MODEL 5 

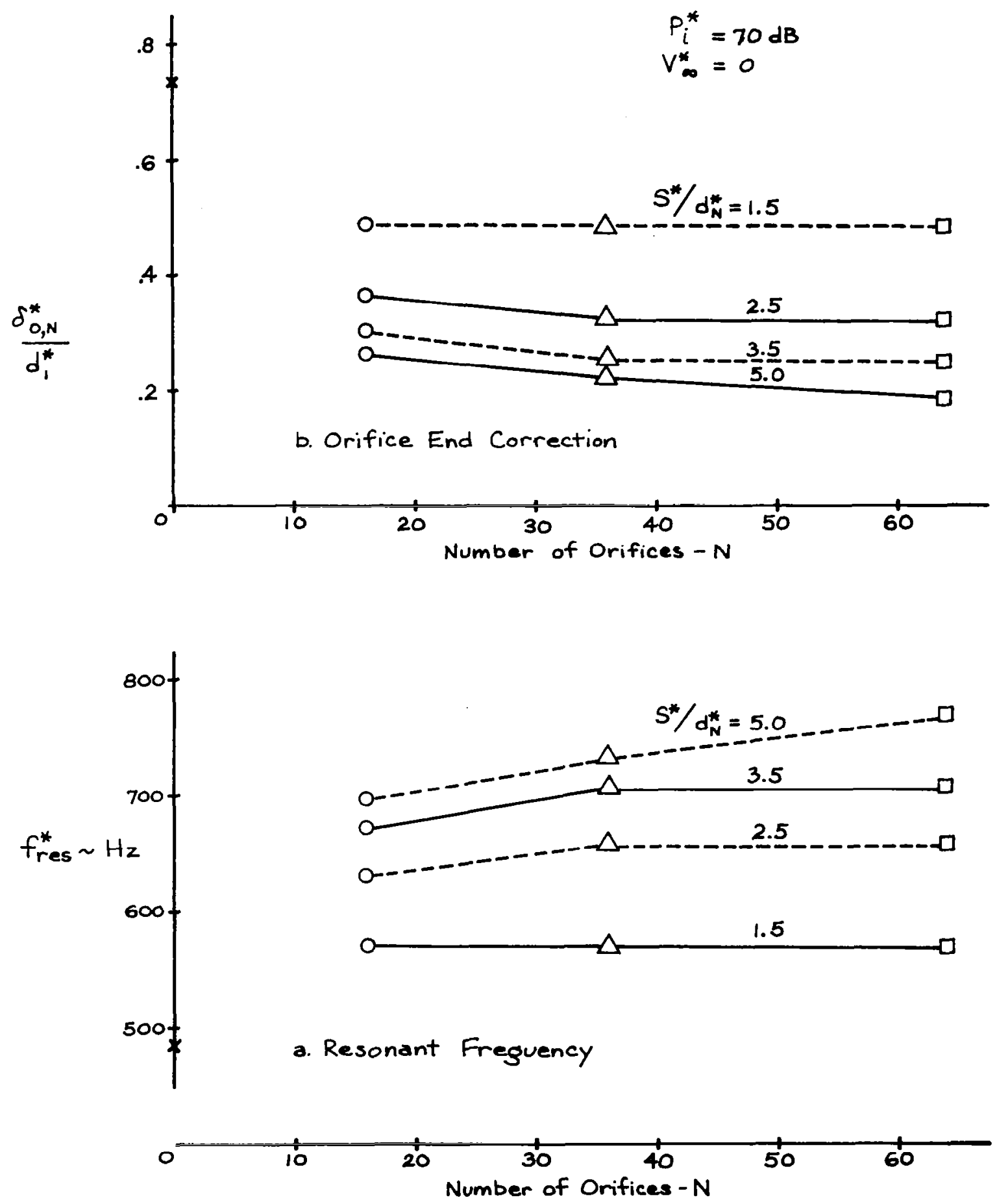

FIGURE 24. EFFECT OF NUMBER OF ORIFICES ON RESONANT FREQUENCY AND ORIFICE END CORRECTION FOR $\mathrm{V}_{\infty}^{*}=0$ and $\mathrm{P}_{i}^{*}=70 \mathrm{~dB}$ 


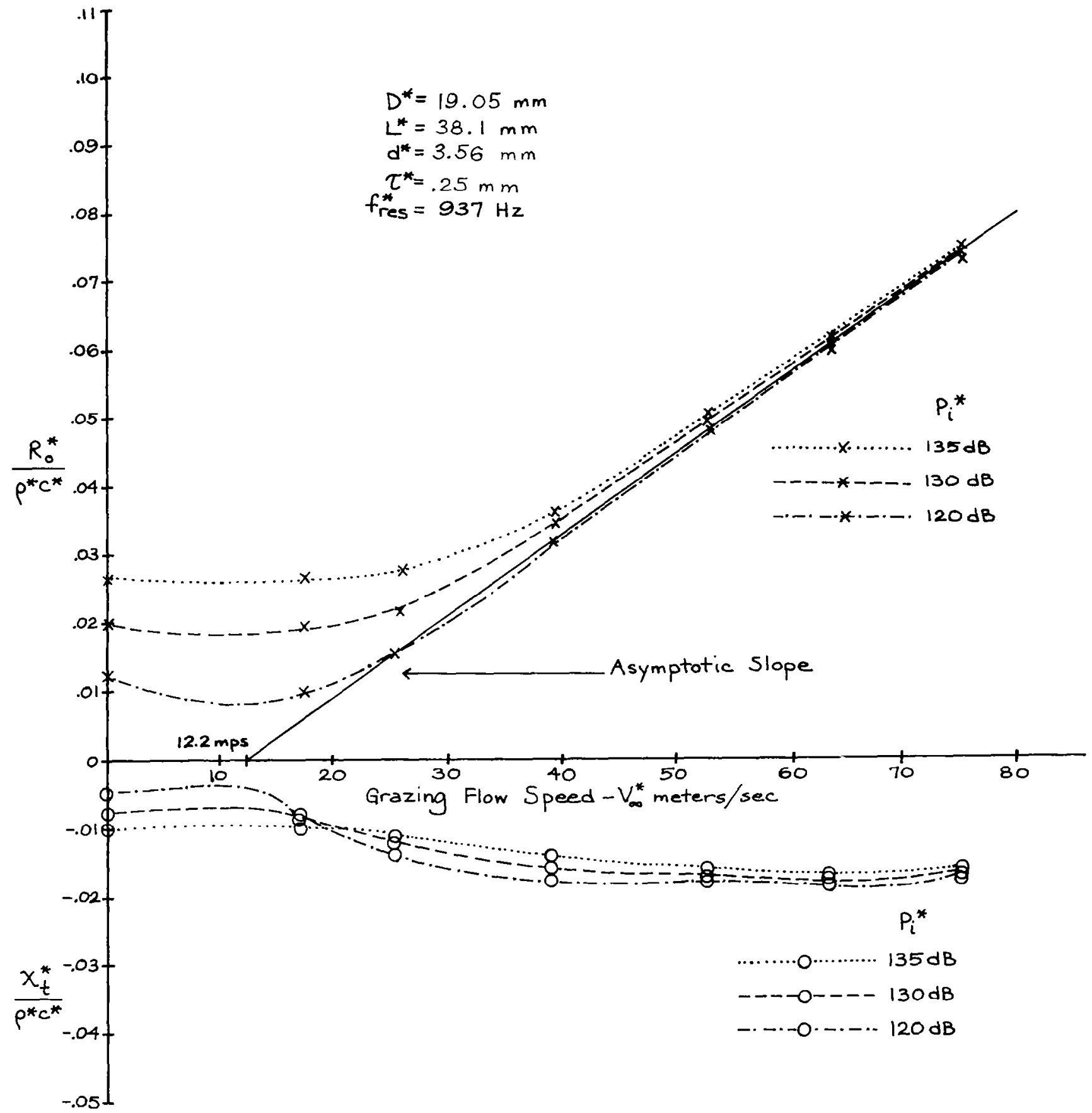

FIGURE 23c. CORRELATION BETWEEN MEASURED AND PREDICTED RESONANT GRAZING FLOW SPEED OF MODEL 6 

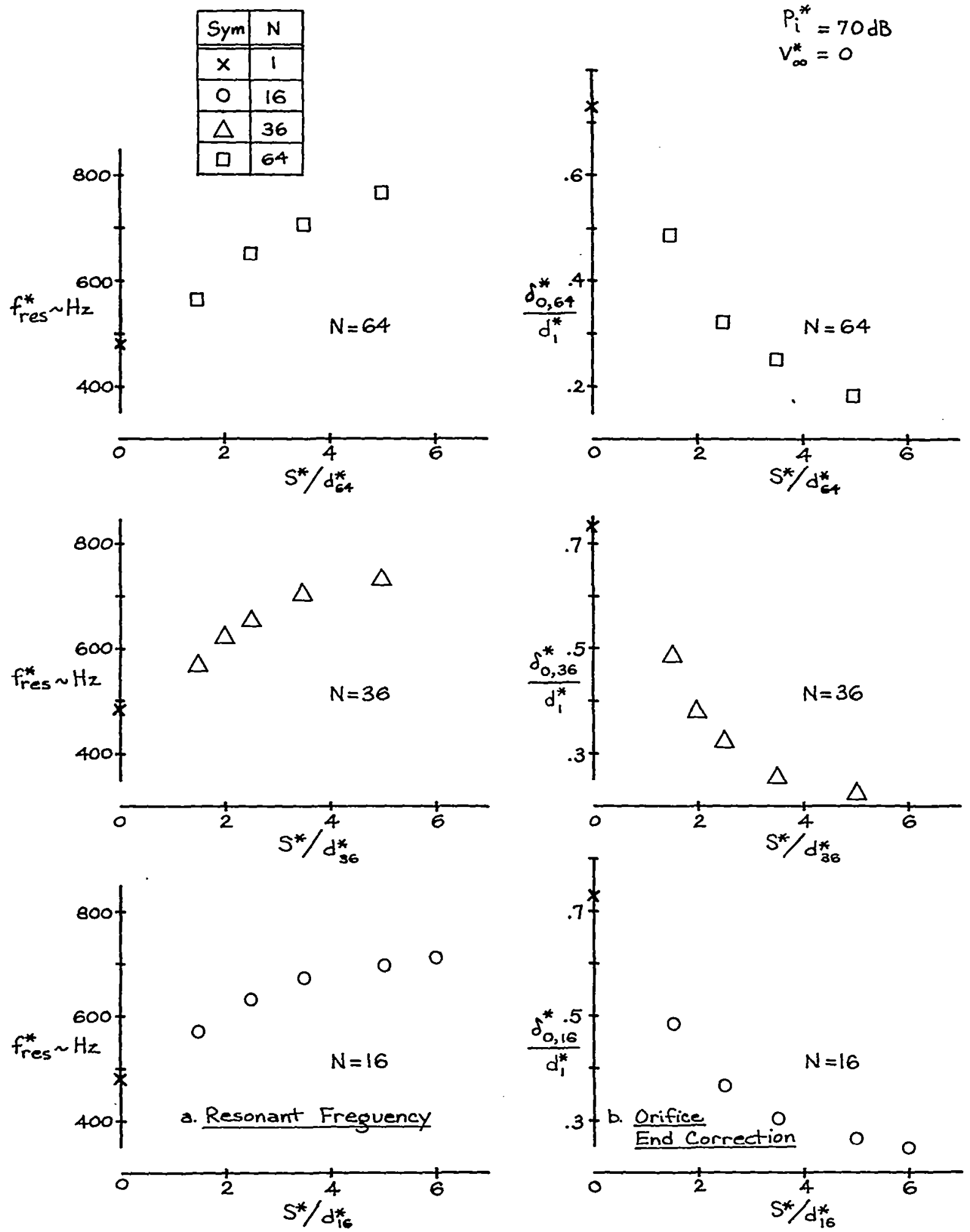

FIGURE $25(\mathrm{a}, \mathrm{b})$ EFFECT OF ARRAY SPACING ON RESONANT FREQUENCY AND ORIFICE END CORRECTION FOR $V_{\infty}^{*=0}$ AND $\mathrm{P}^{*}=70 \mathrm{~dB}$ 


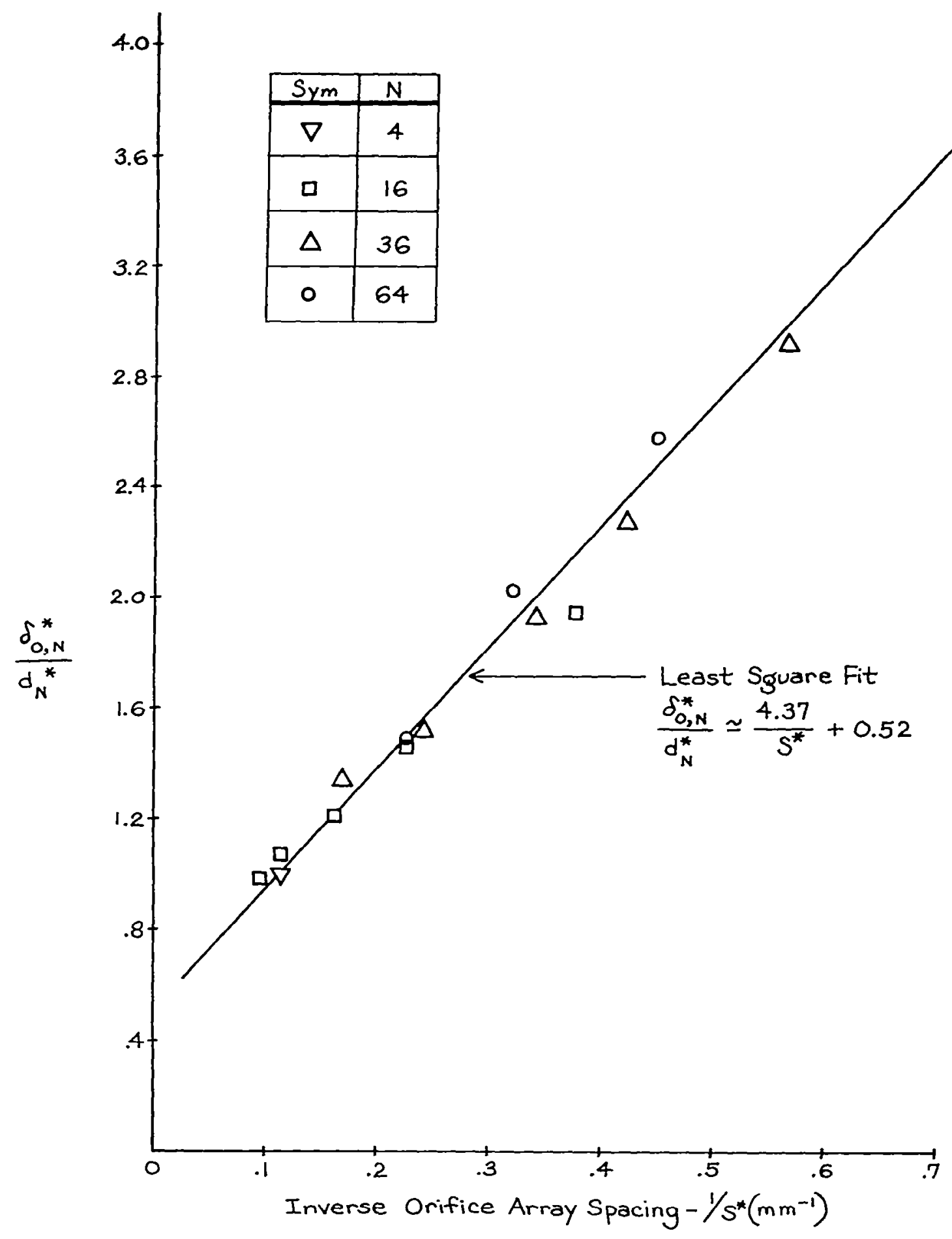

FIGURE 25C. EFFECT OF ARRAY SPACING ON ORIFICE END CORRECTION FOR $V_{\infty}^{*}=0$ AND $P_{i}^{*}=70 \mathrm{~dB}$ 


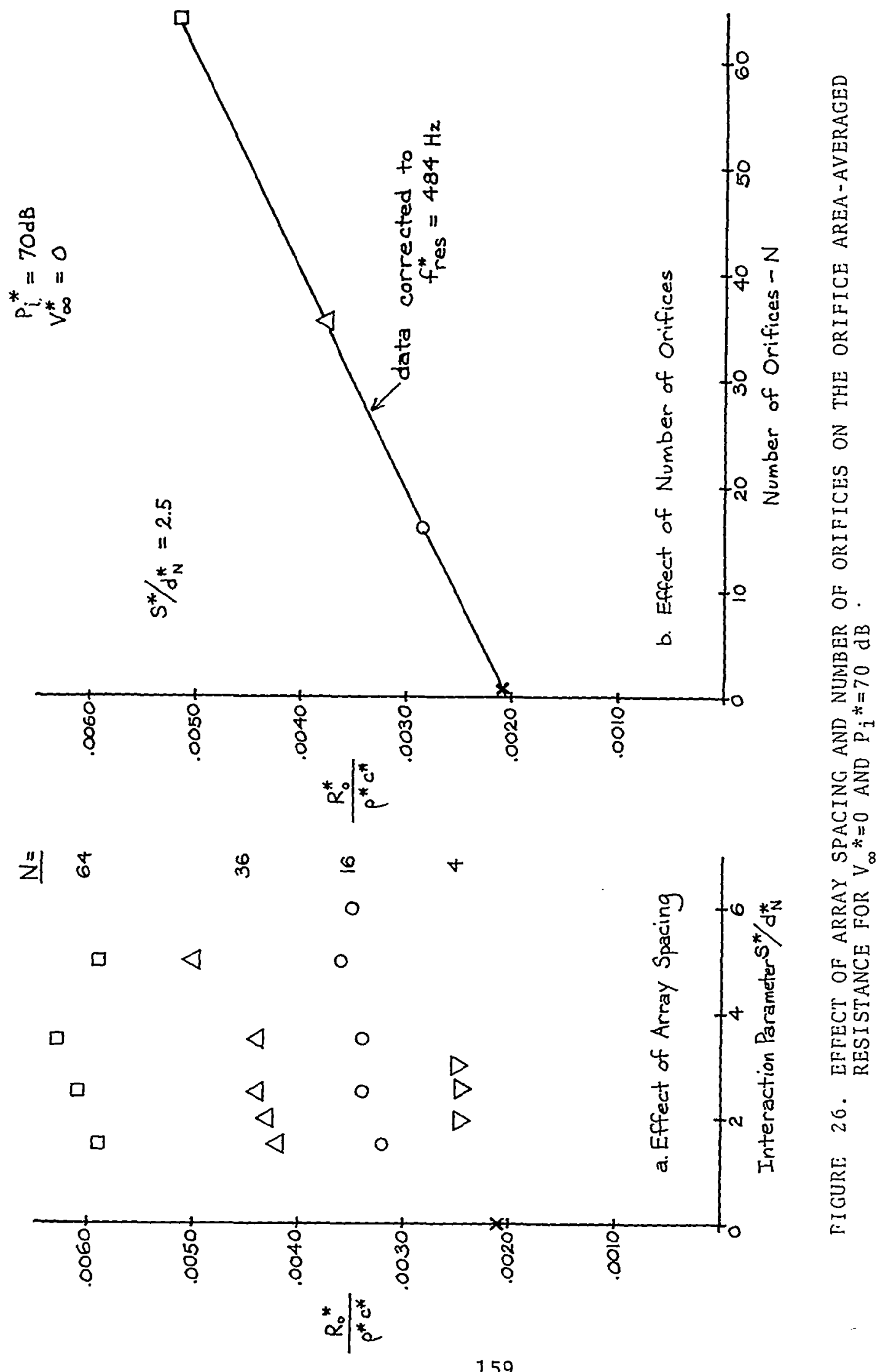




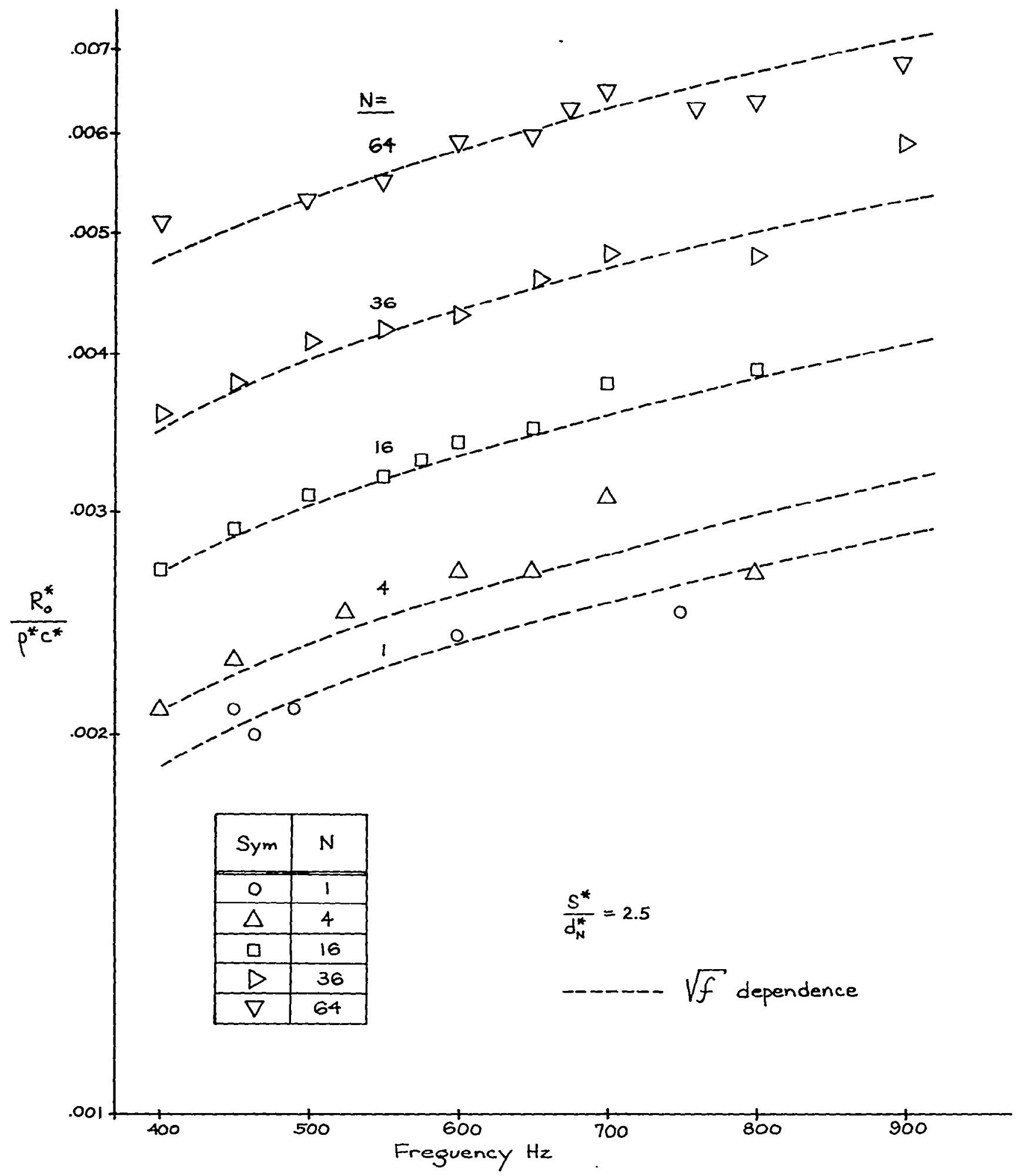

FIGURE 27. EFFECT OF FREQUENCY VARIATION ON THE ORIFICE AREAAVERAGED RESISTANCE FOR THE $N=1,4,16,36$ AND 64 CONFIGURATION FOR $V_{\infty}^{*}=0, P_{C}^{*}=70 \mathrm{~dB}$ 


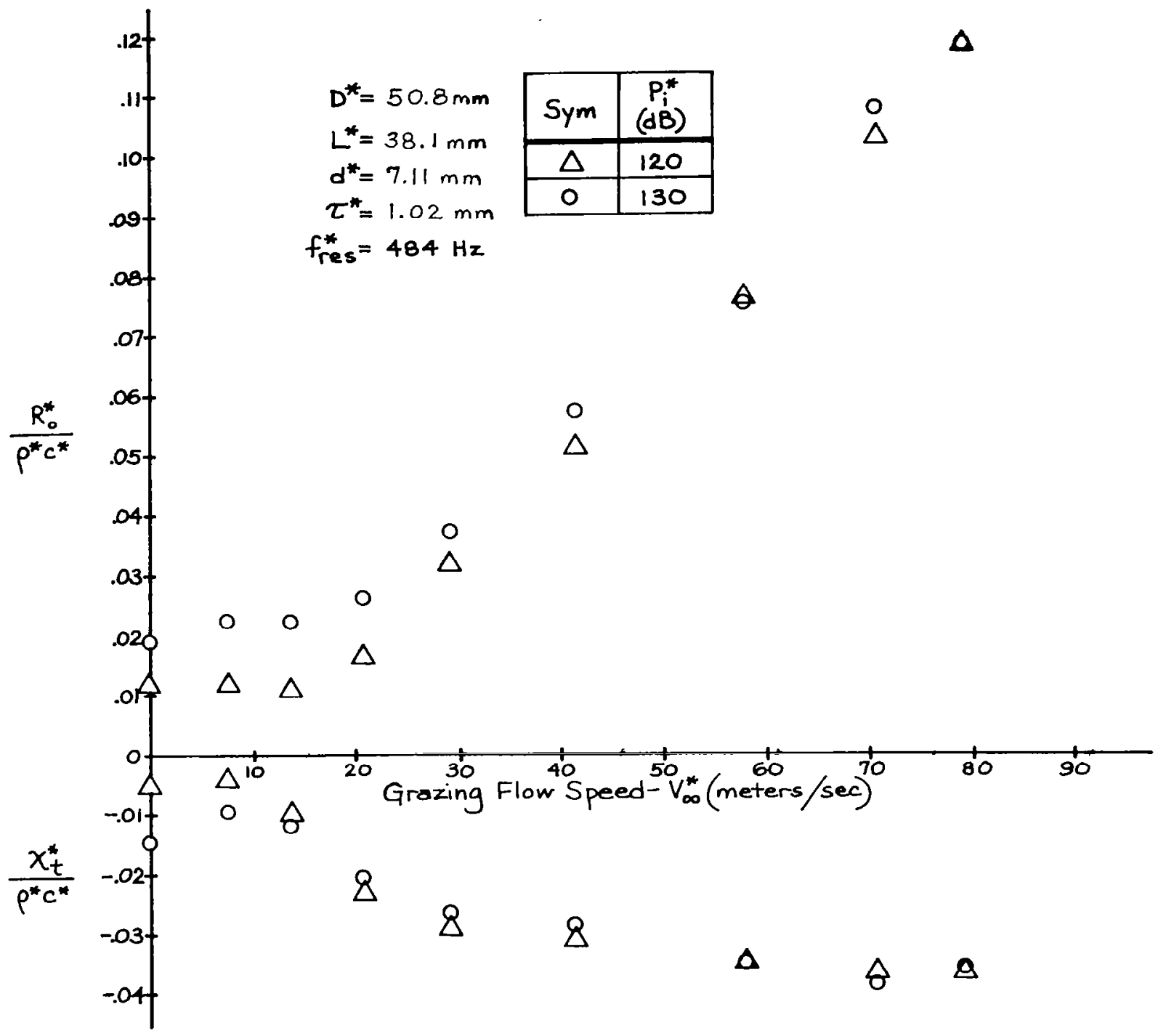

FIGURE 28. EFFECT OF GRAZING FLOW ON THE ORIFICE AREA-AVERAGED IMPEDANCE OF THE $\mathrm{N}=1$ CONFIGURATION 


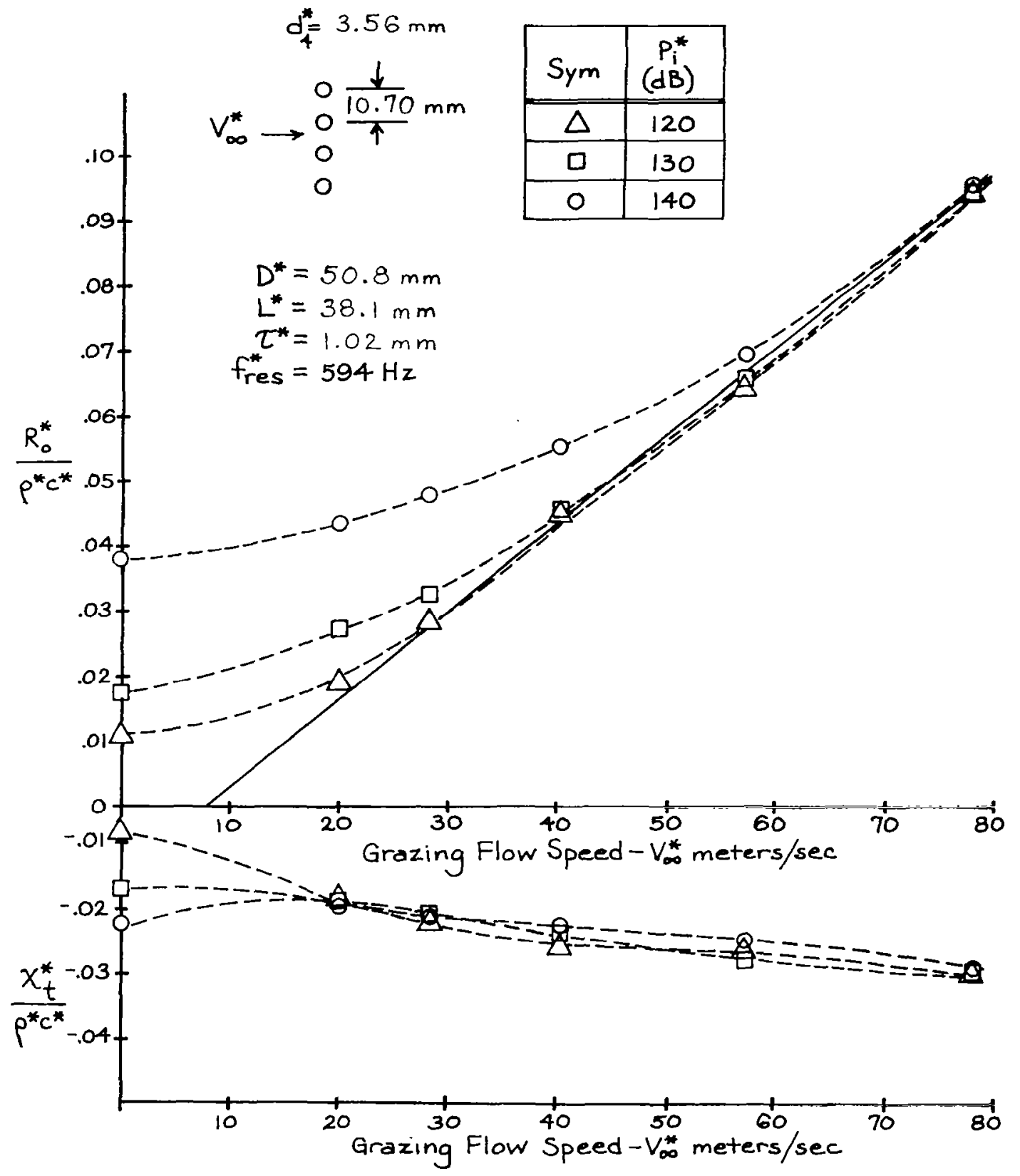

FIGURE 29a. EFFECT OF GRAZING FLOW ON THE IMPEDANCE OF THE PERPENDICULARLY ORIENTATED FOUR-ORIFICE ARRAY CONFIGURATION $-\mathrm{S}^{*} / \mathrm{d}_{4} *=3.0$ 


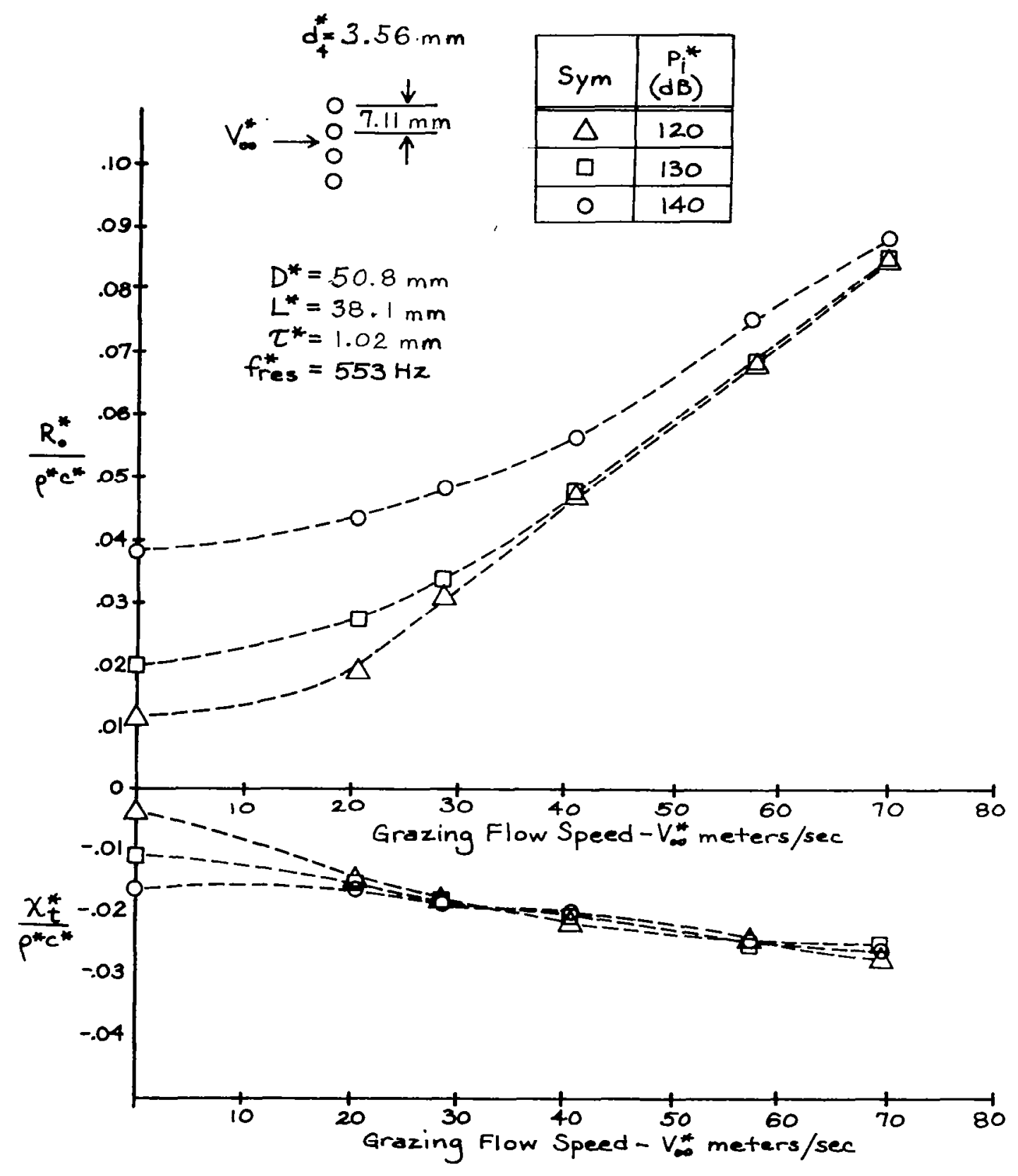

FIGURE 29b. EFFECT OF GRAZING FLOW ON THE IMPEDANCE OF THE PERPENDICULARLY ORIENTATED FOUR-ORIFICE ARRAY CONFIGURATION $-\mathrm{S}^{*} / \mathrm{d}_{4} *=2.0$ 


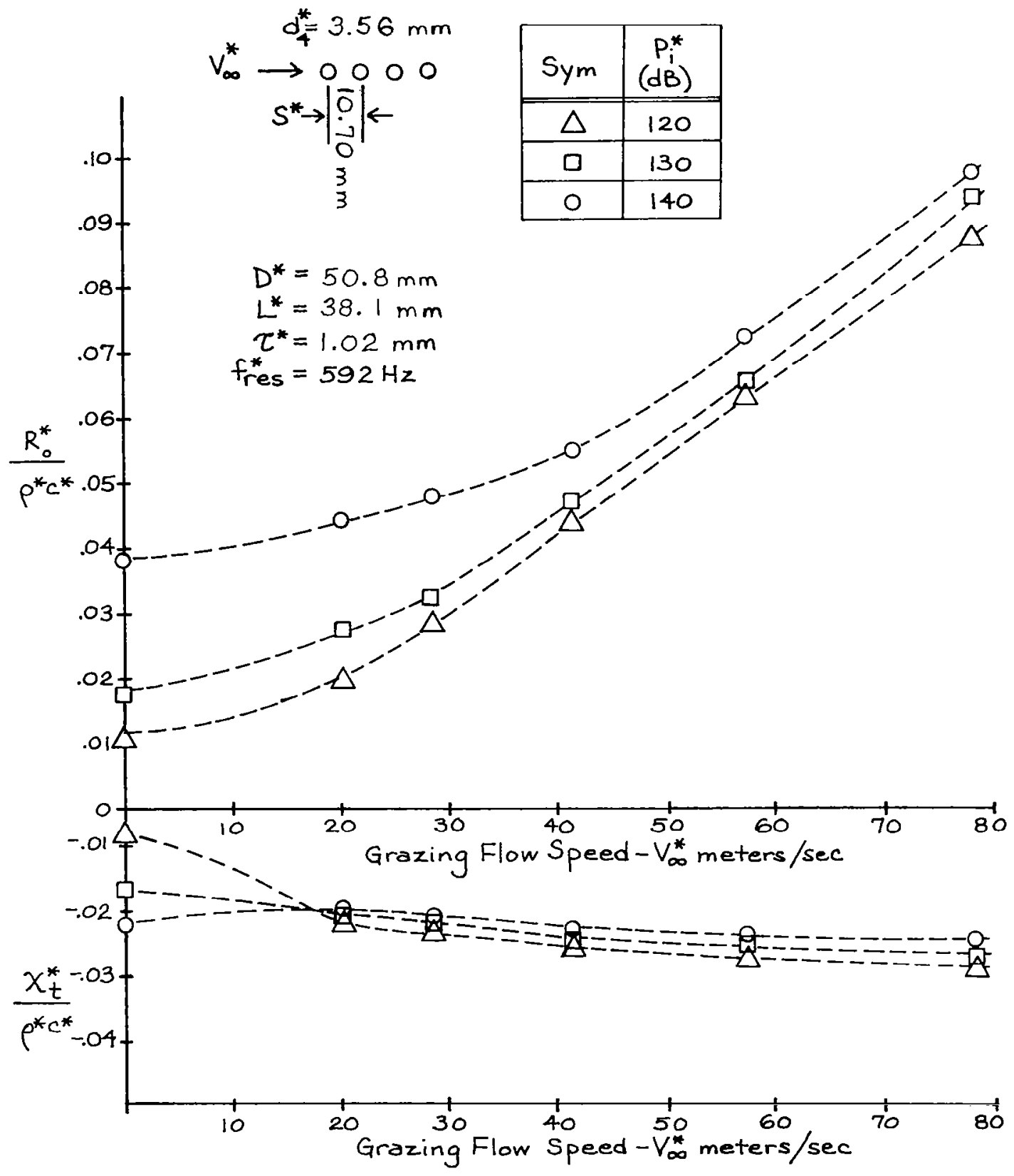

FIGURE 29C. EFFECT OF GRAZTNG FLOW ON THE IMPEDANCE OF THE COLINEARLY ORIENTATED FOUR-ORIFICE ARRAY CONFIGURATION $-\mathrm{S} * / \mathrm{d}_{4} *=3.0$ 


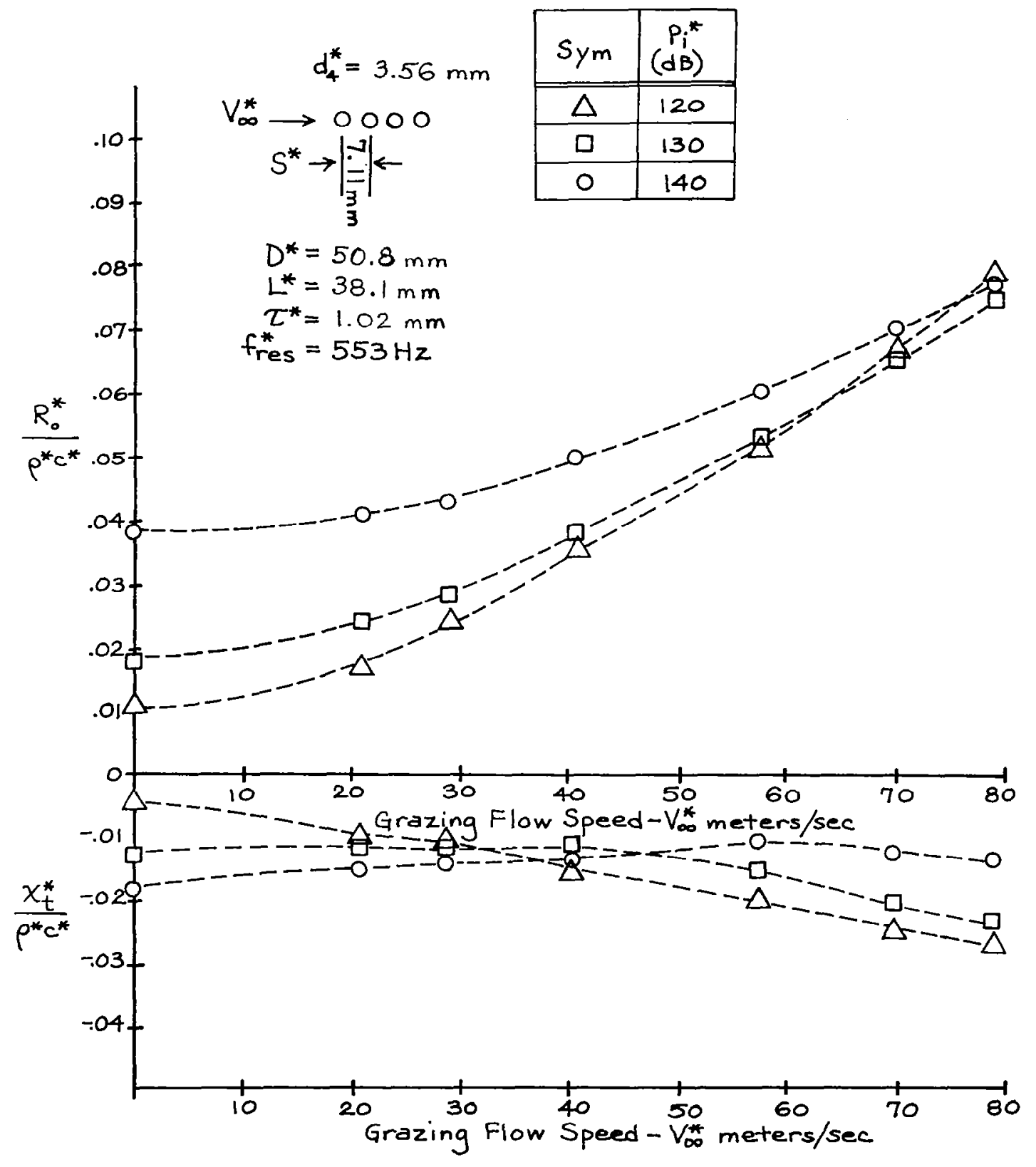

FIGURE 29d. EFFECT OF GRAZING FLOW ON THE IMPEDANCE OF THE COLINEARLY ORIENTATED FOUR-ORIFICE ARRAY CONFIGURATION $-\mathrm{S} * / \mathrm{d}_{4} *=2.0$ 


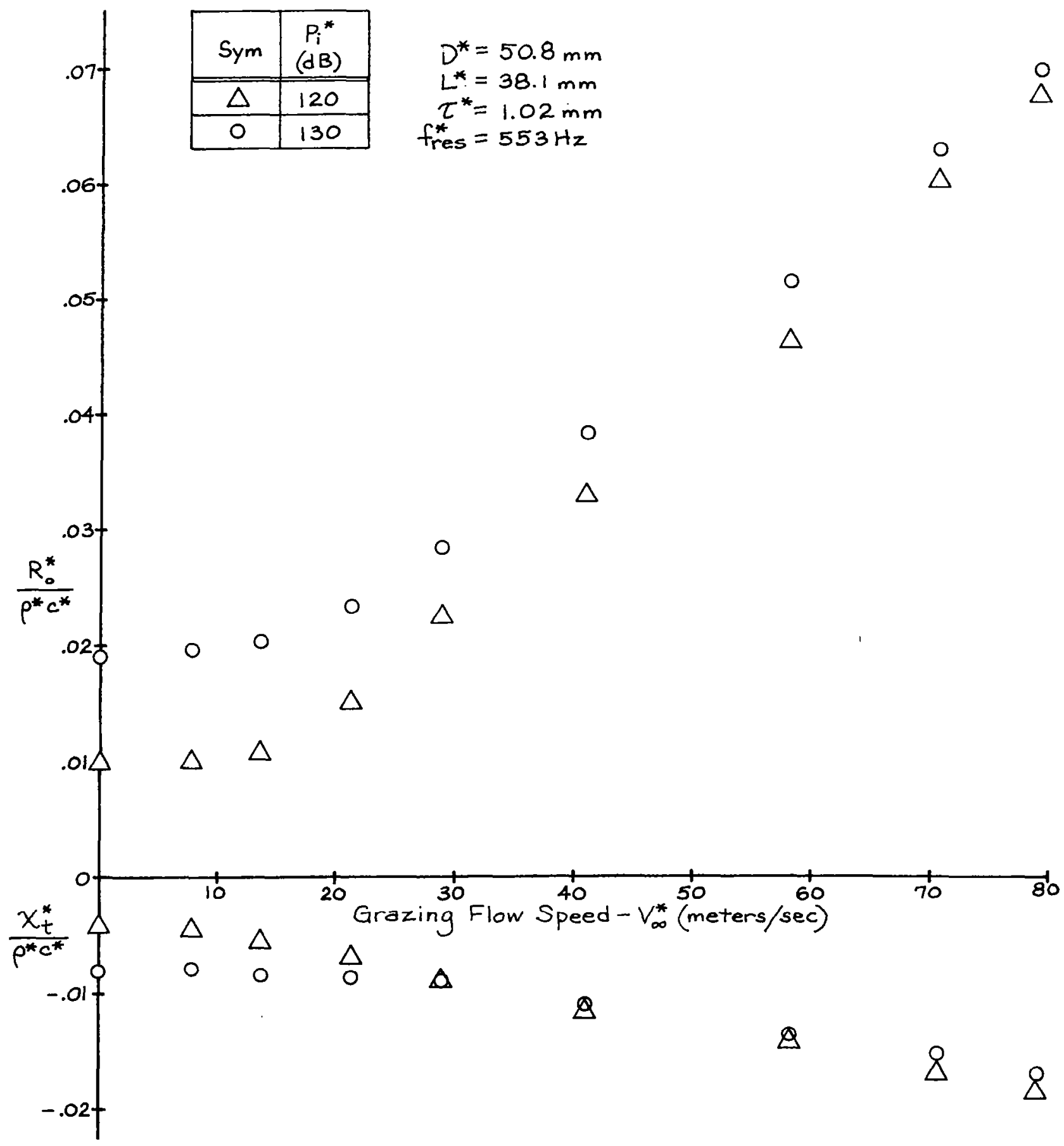

FIGURE 30a. EFFECT OF GRAZING FLOW ON THE ORIFICE AREA-AVERAGED IMPEDANCE OF THE $\mathrm{N}=16, \mathrm{~S}^{*} / \mathrm{d}_{16} *=2.5$ CONFIGURA'IION 


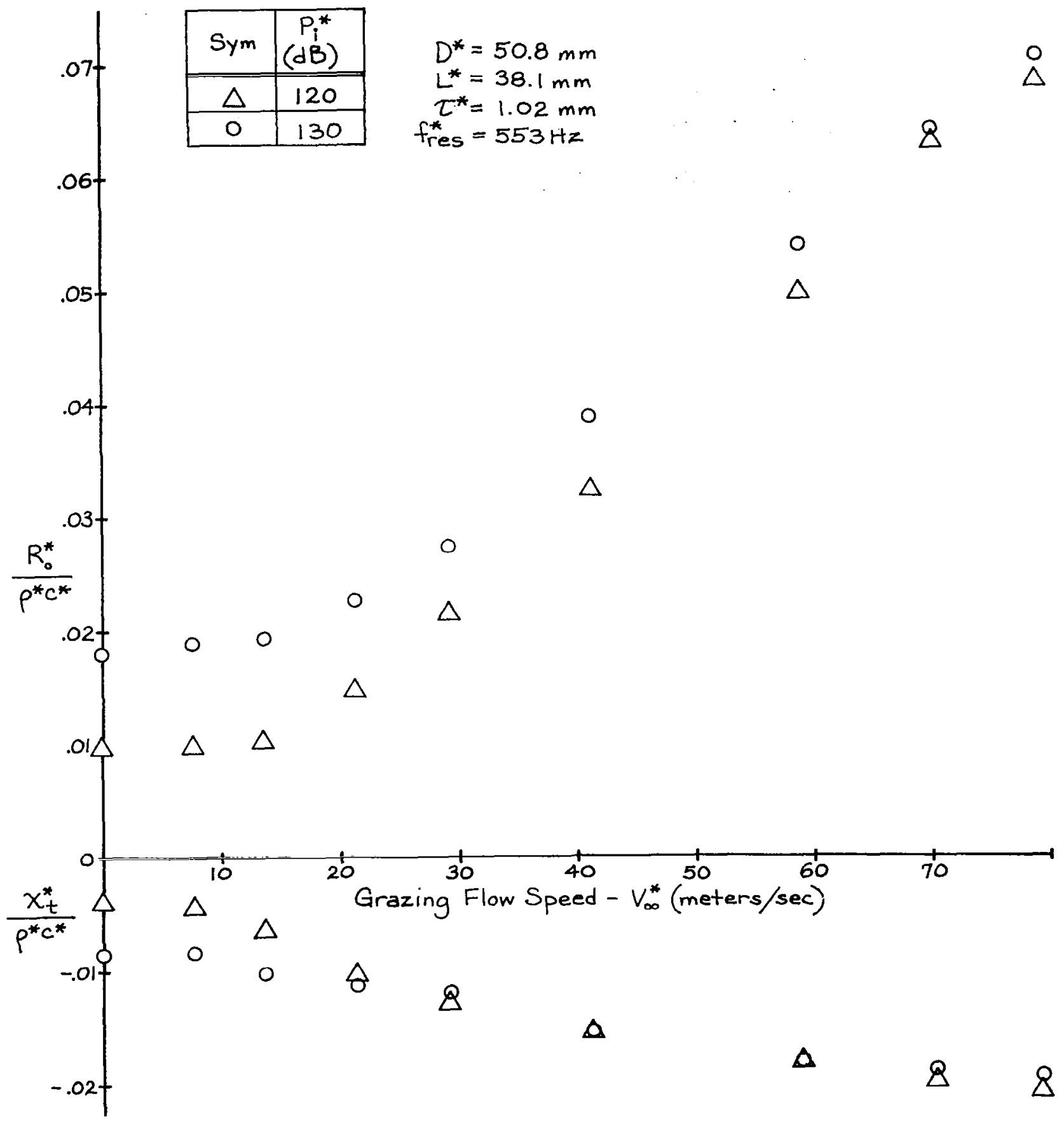

FIGURE $30 \mathrm{~b}$. EFFECT OF GRAZING FLOW ON THE ORIFICE AREA-AVERAGED IMPEDANCE OF THE $\mathrm{N}=16, \mathrm{~S}^{*} / \mathrm{d}_{16} *=5$ CONFIGURATION 


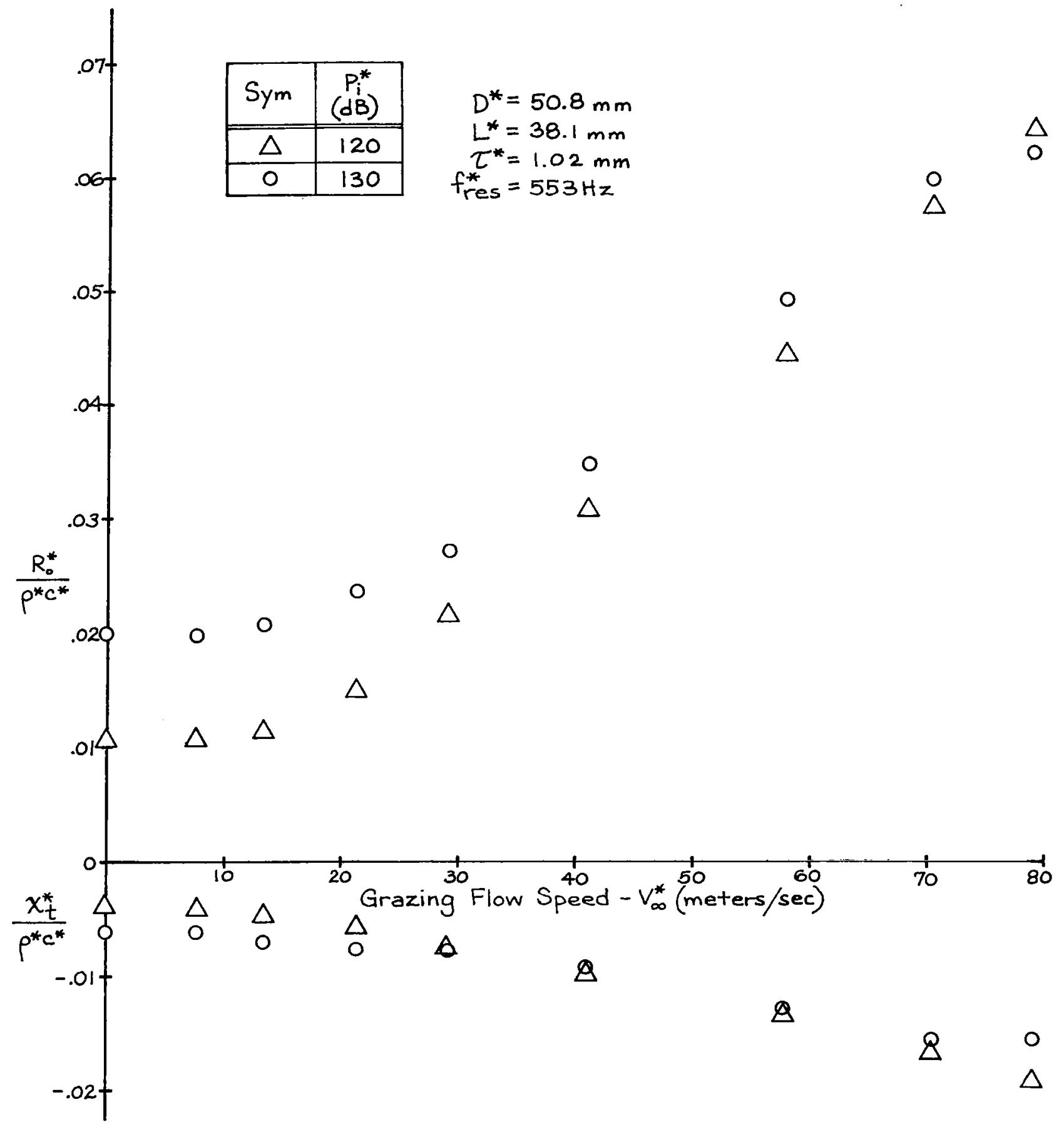

FIGURI: $31 \mathrm{a}$. EFFECT OF GRAZING FLOW ON THE ORIFICE AREA-AVERAGED IMPEDANCE OF THE $\mathrm{N}=36, \mathrm{~S}^{*} / \mathrm{d}_{36^{*}}=2.5$ CONFIGURATION 


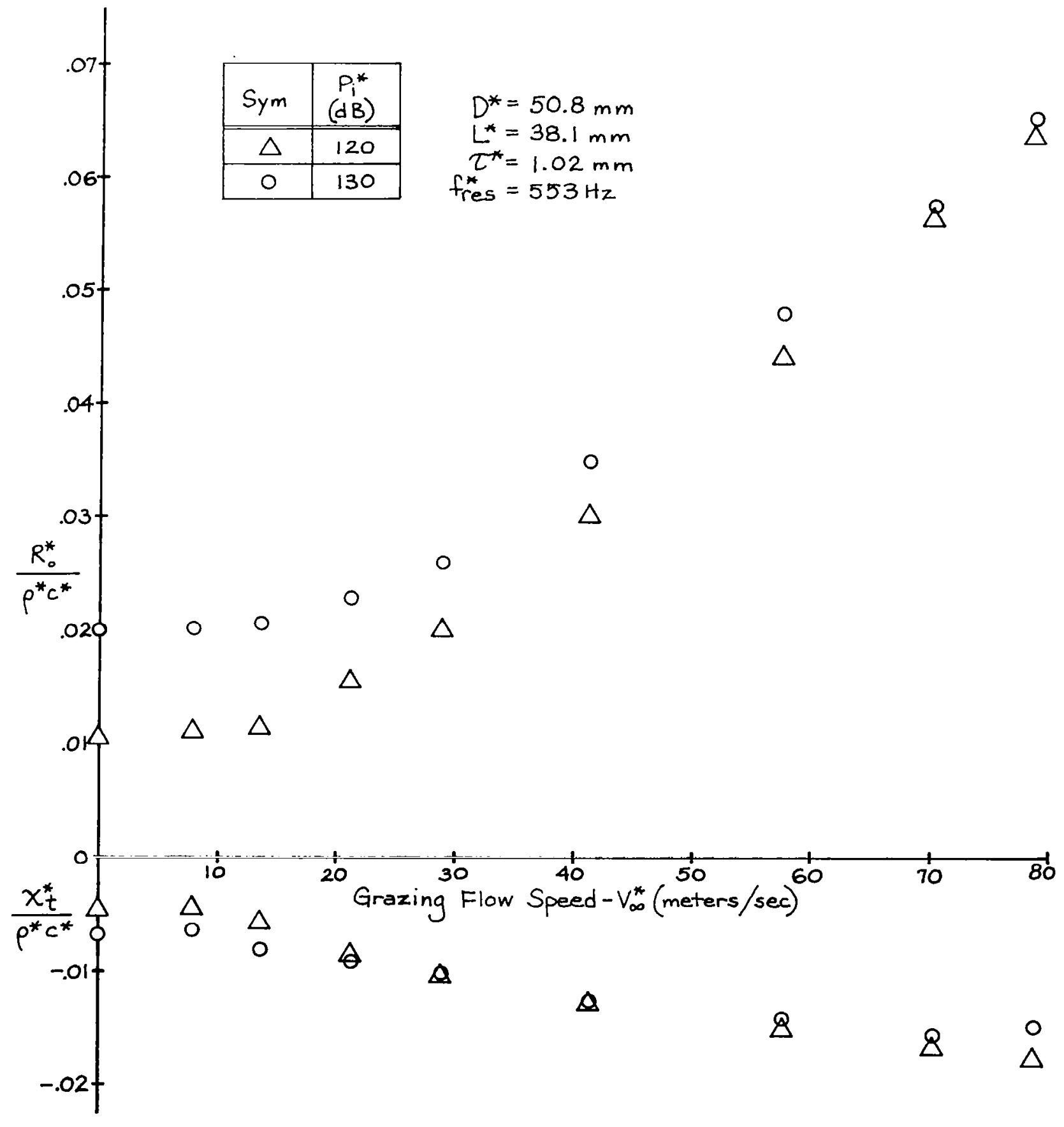
FIGURE $31 \mathrm{~b}$. EFFECT OF GRAZING FLOW ON THE ORIFICE AREA-AVERAGED
IMPEDANCE OF THE N=36, $\mathrm{s}^{*} / \mathrm{d}_{36} *=5$ CONFIGURATION 


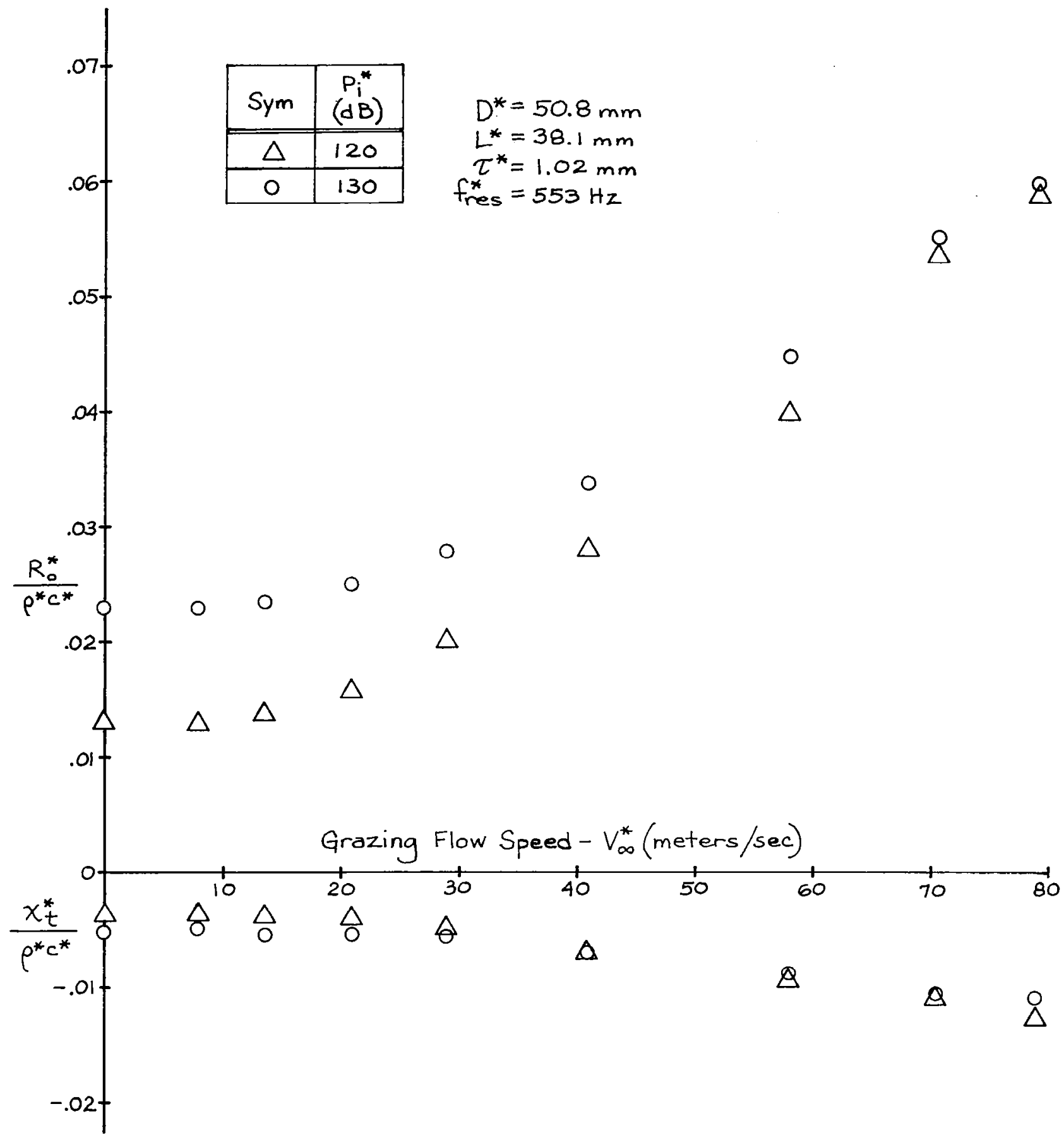

FIGURE $32 \mathrm{a}$. EFFECT OF GRAZING FLOW ON THE ORIFICE AREA-AVERAGED IMPEDANCE OF THE $\mathrm{N}=64, \mathrm{~S}^{*} / \mathrm{d}_{64} *=2.5$ CONFIGURATION 


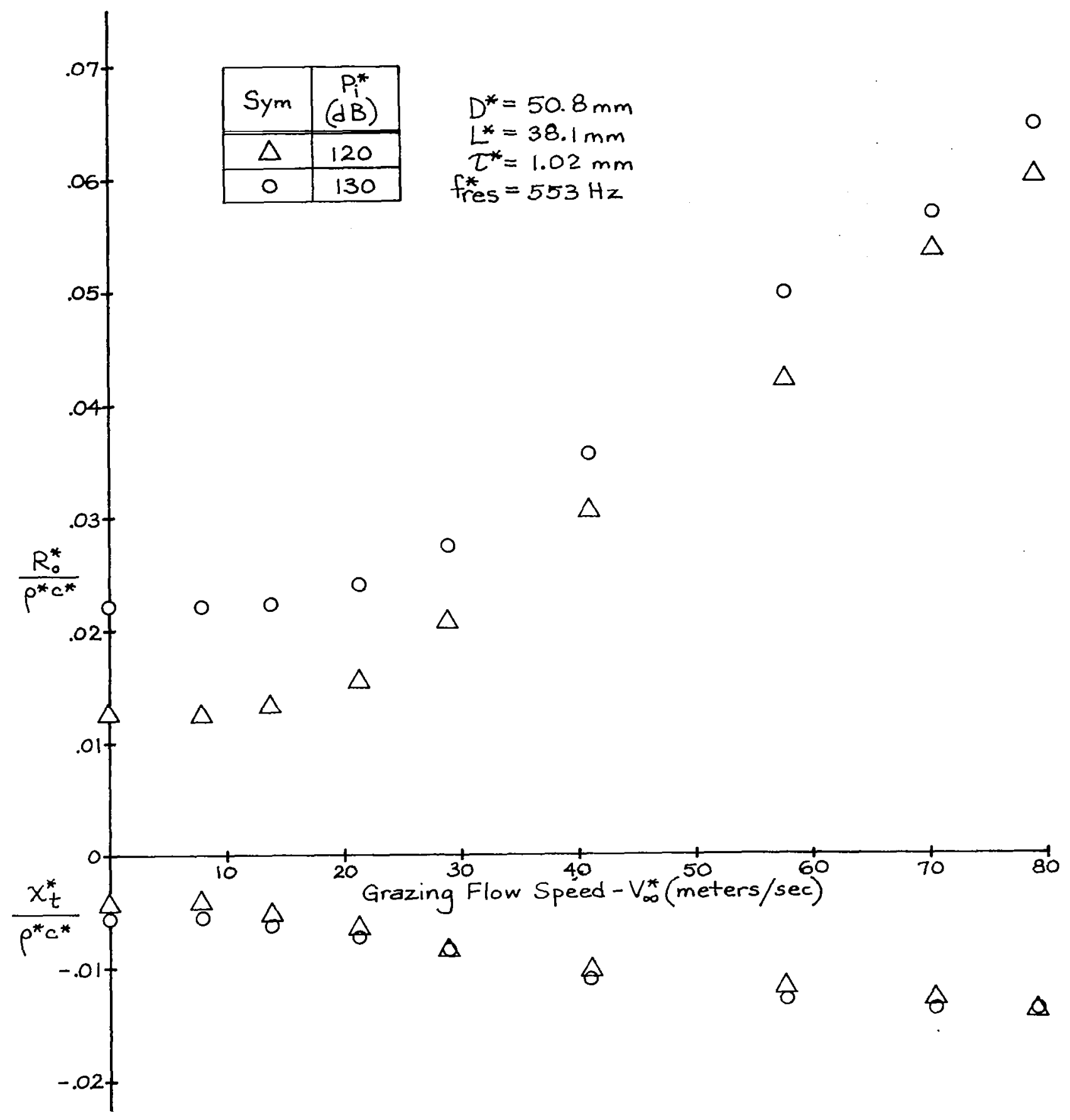

FIGURE $32 \mathrm{~b}$. EFFECT OF GRAZING FLOW ON THE ORIFICE AREA-AVERAGED IMPEDANCE OF THE $\mathrm{N}=64, \mathrm{~S}^{*} / \mathrm{d}_{64} *=5$ CONFIGURATION 


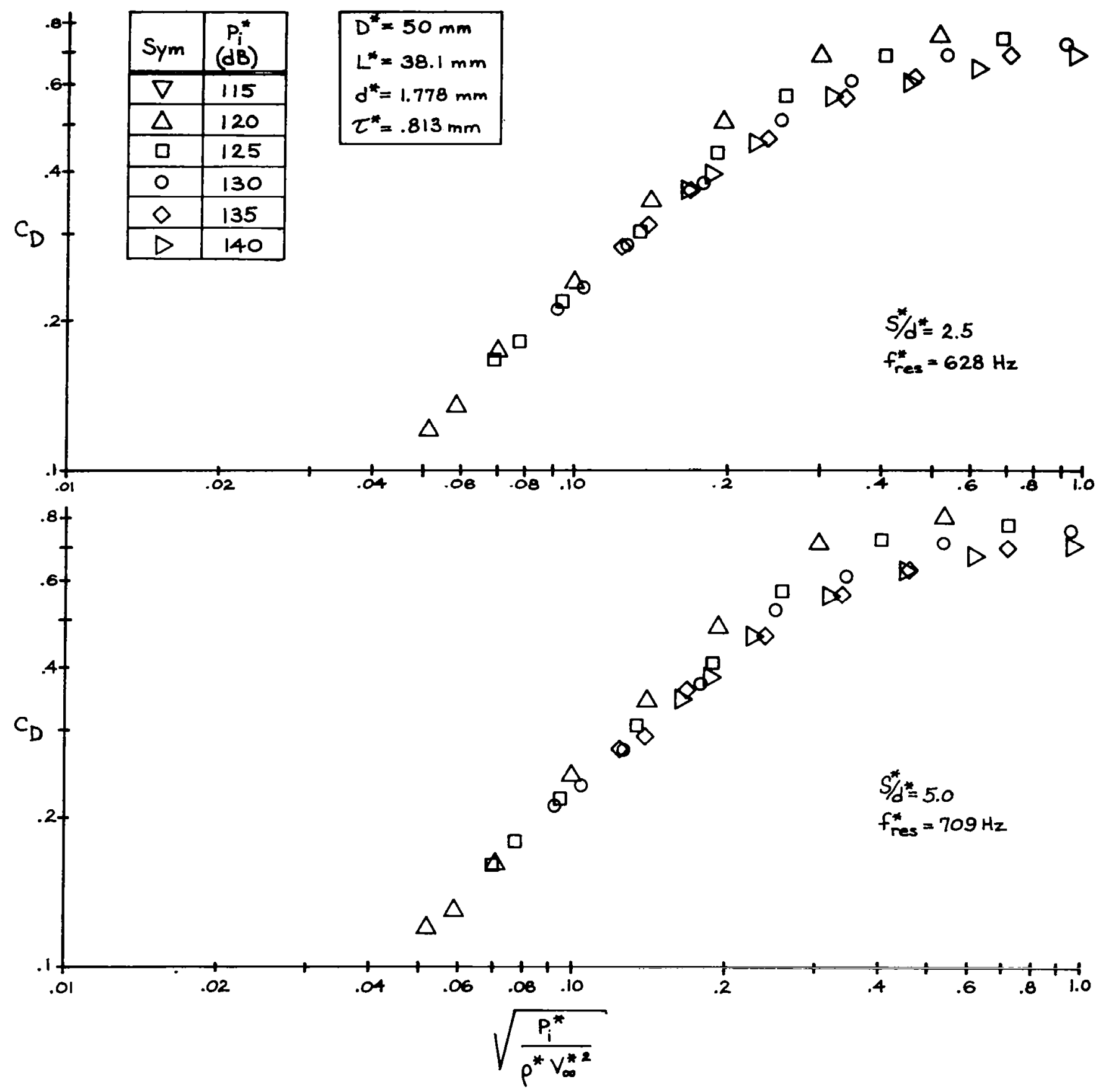

FIGURE $33(\mathrm{a}, \mathrm{b})$ CORRELATION OF ORIFICE ARRAY SPACING DATA FOR N=16 IN TERMS OF DISCHARGE COEFFICIENT

172 

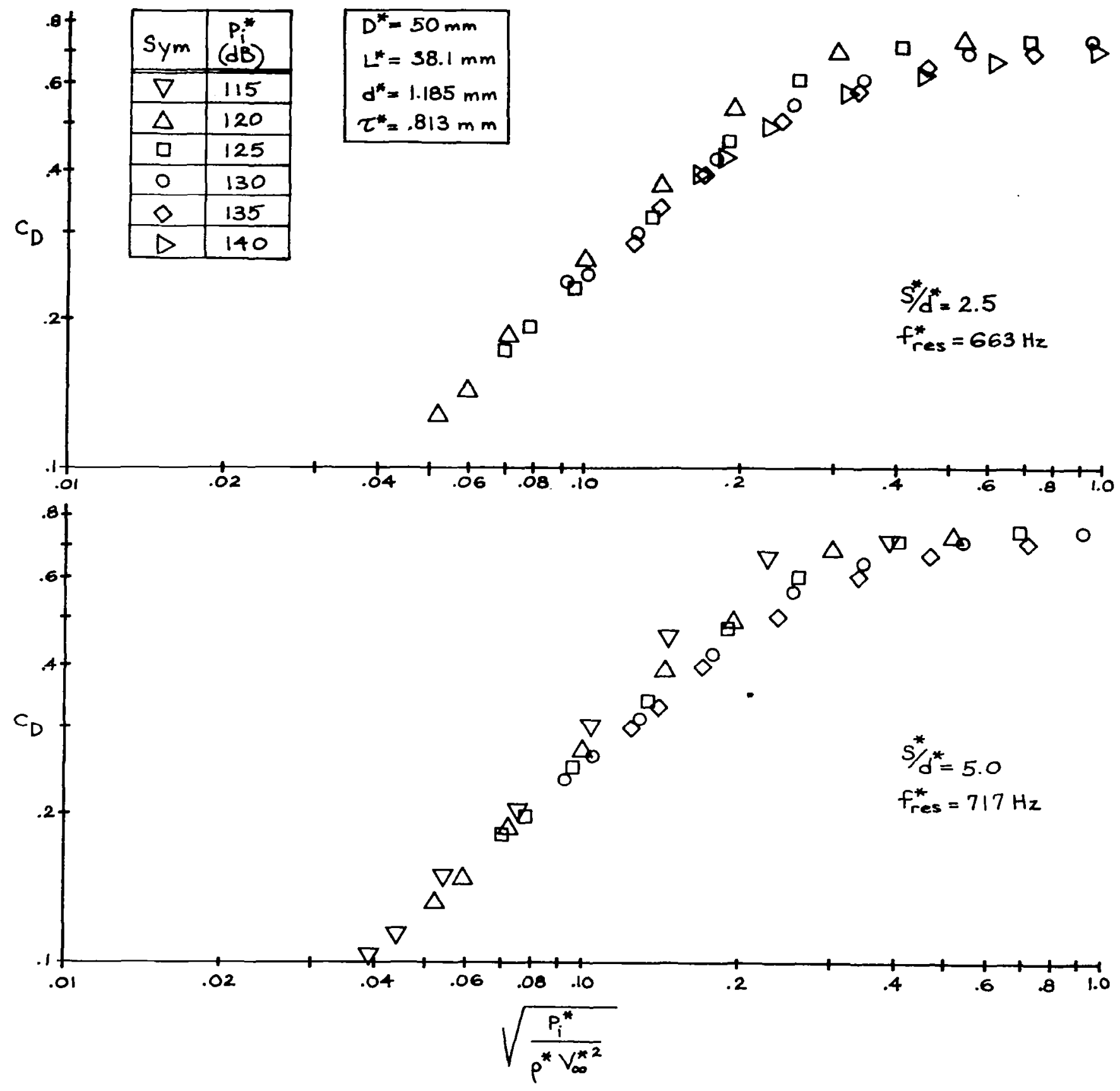

FIGURE $34(\mathrm{a}, \mathrm{b})$ CORRELATION OF ORIFICE ARRAY SPACING D $A T \Lambda$ FOR $\mathrm{N}=36$ IN TERMS OF DISCHARGE COEFFICIENT 


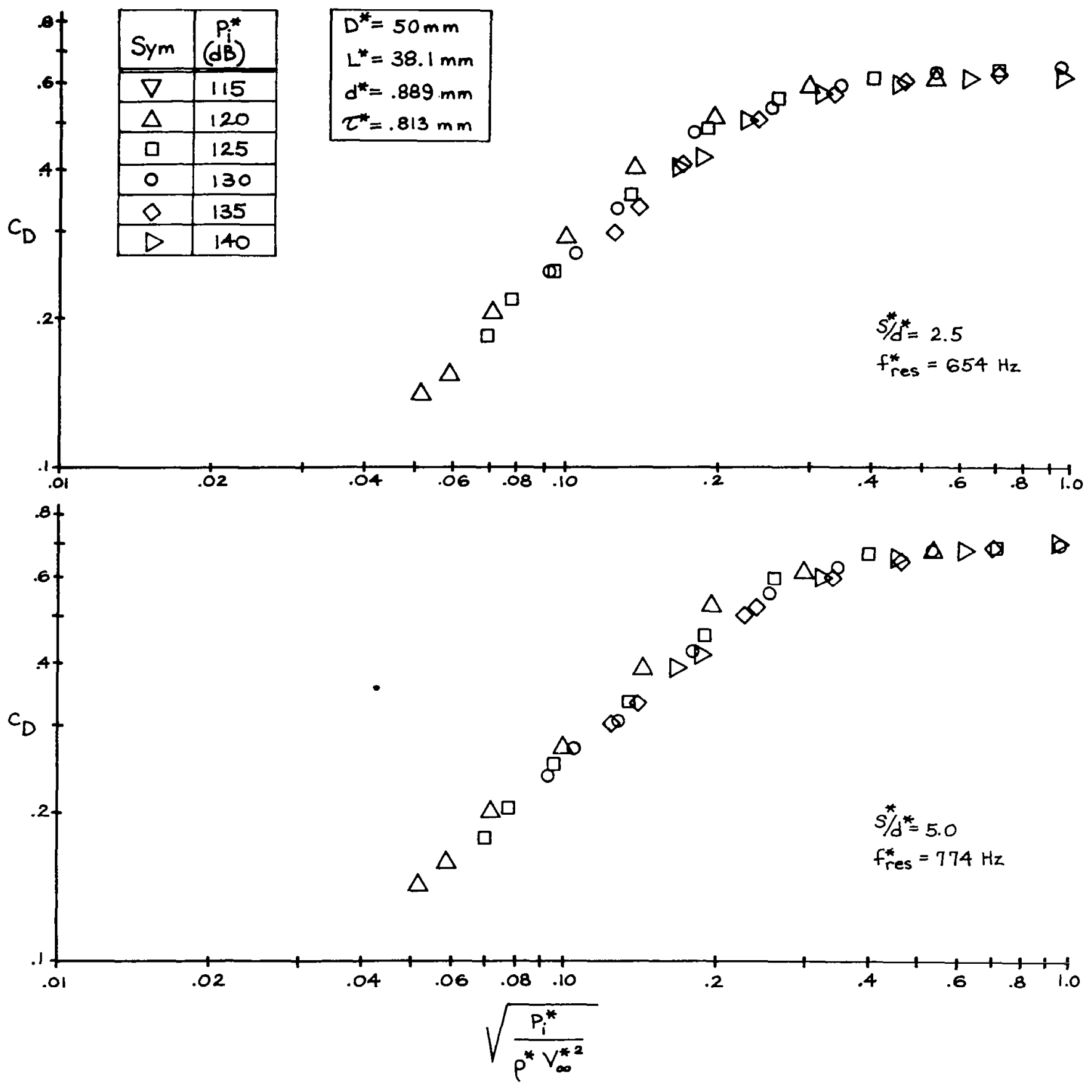

FIGURE $35(\mathrm{a}, \mathrm{b})$. CORRELATION OF ORIFICE ARRAY SPACING DATA FOR $\mathrm{N}=64$ IN TERMS OF DISCHARGE COEFFICIENT 


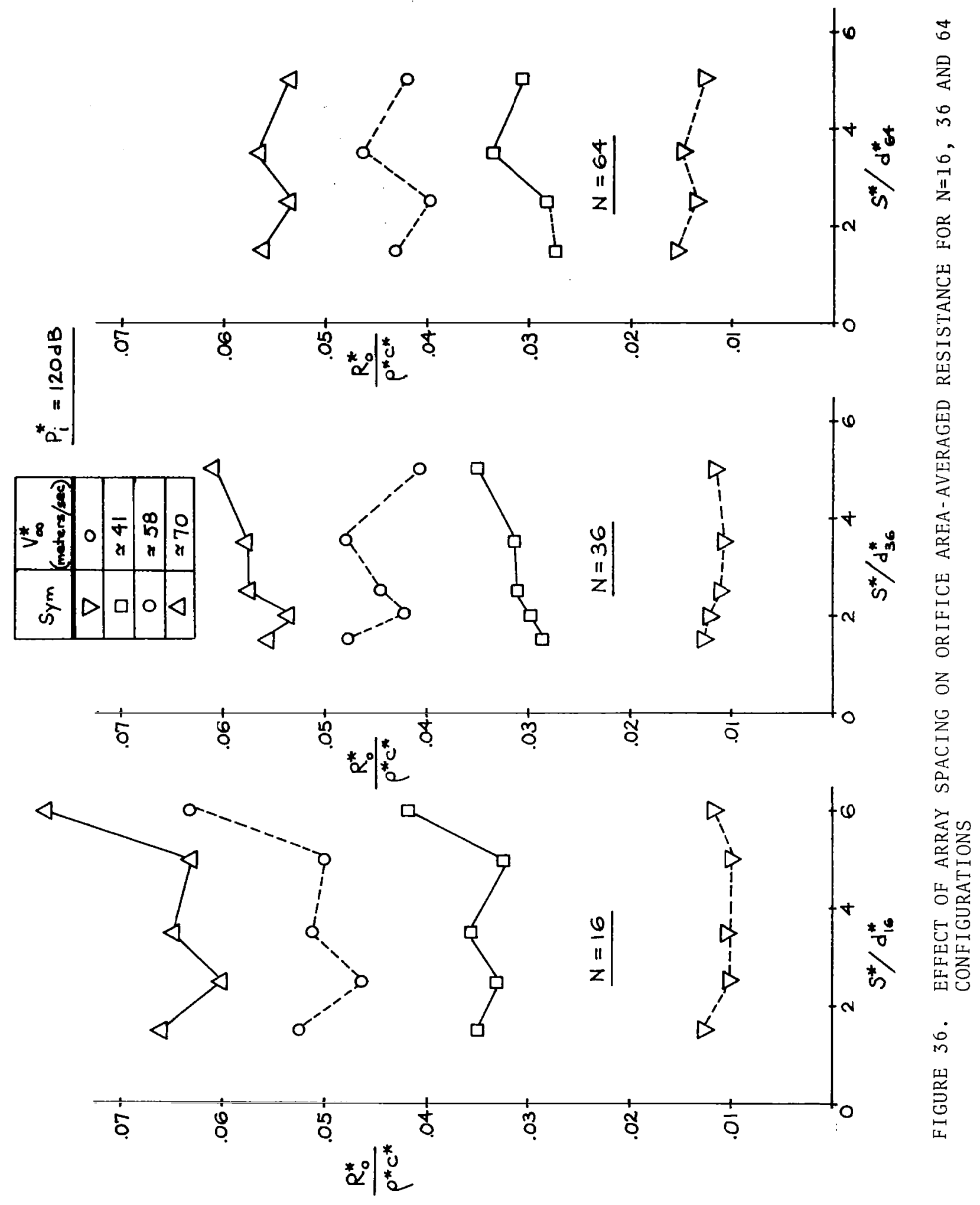




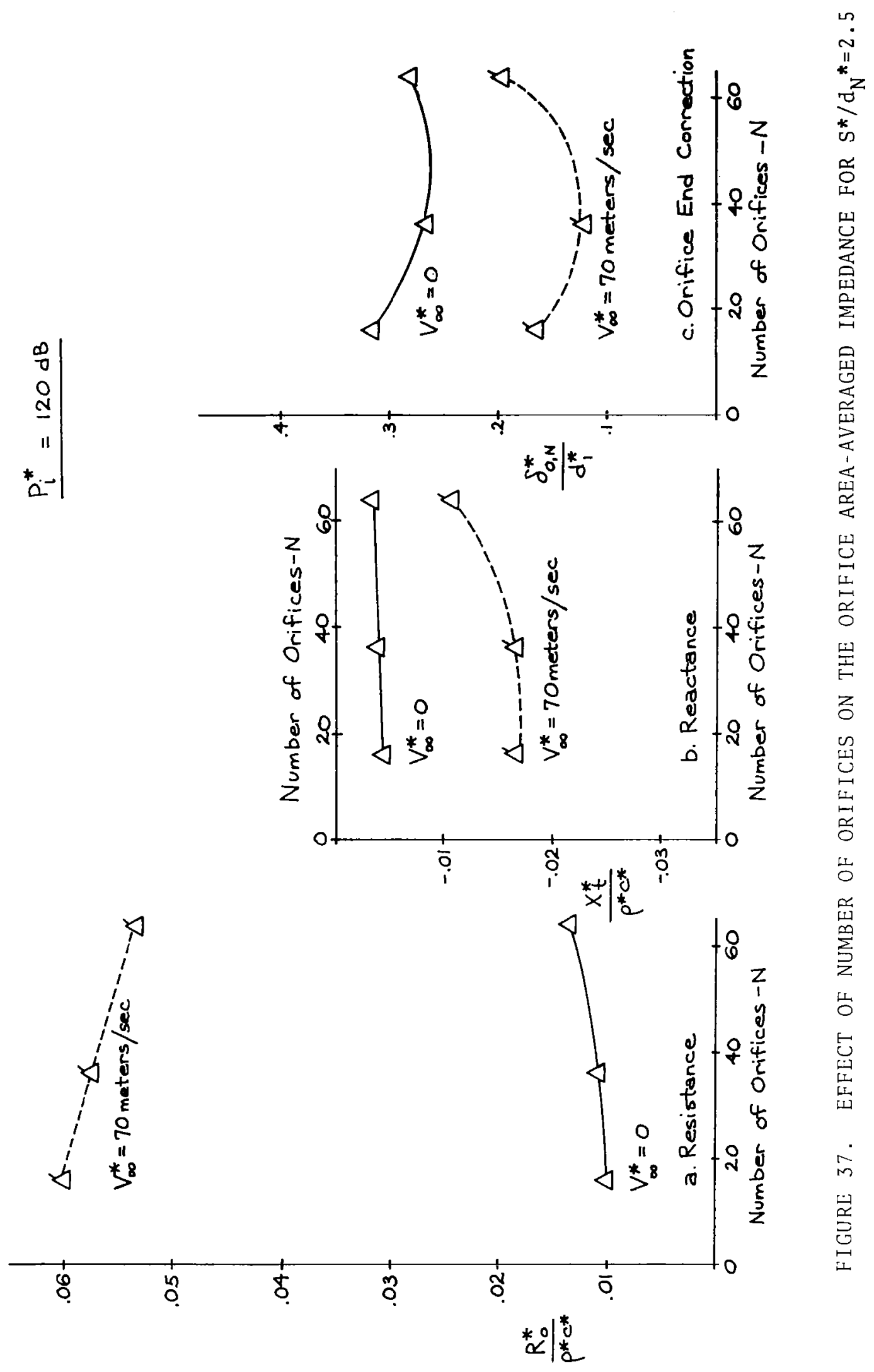




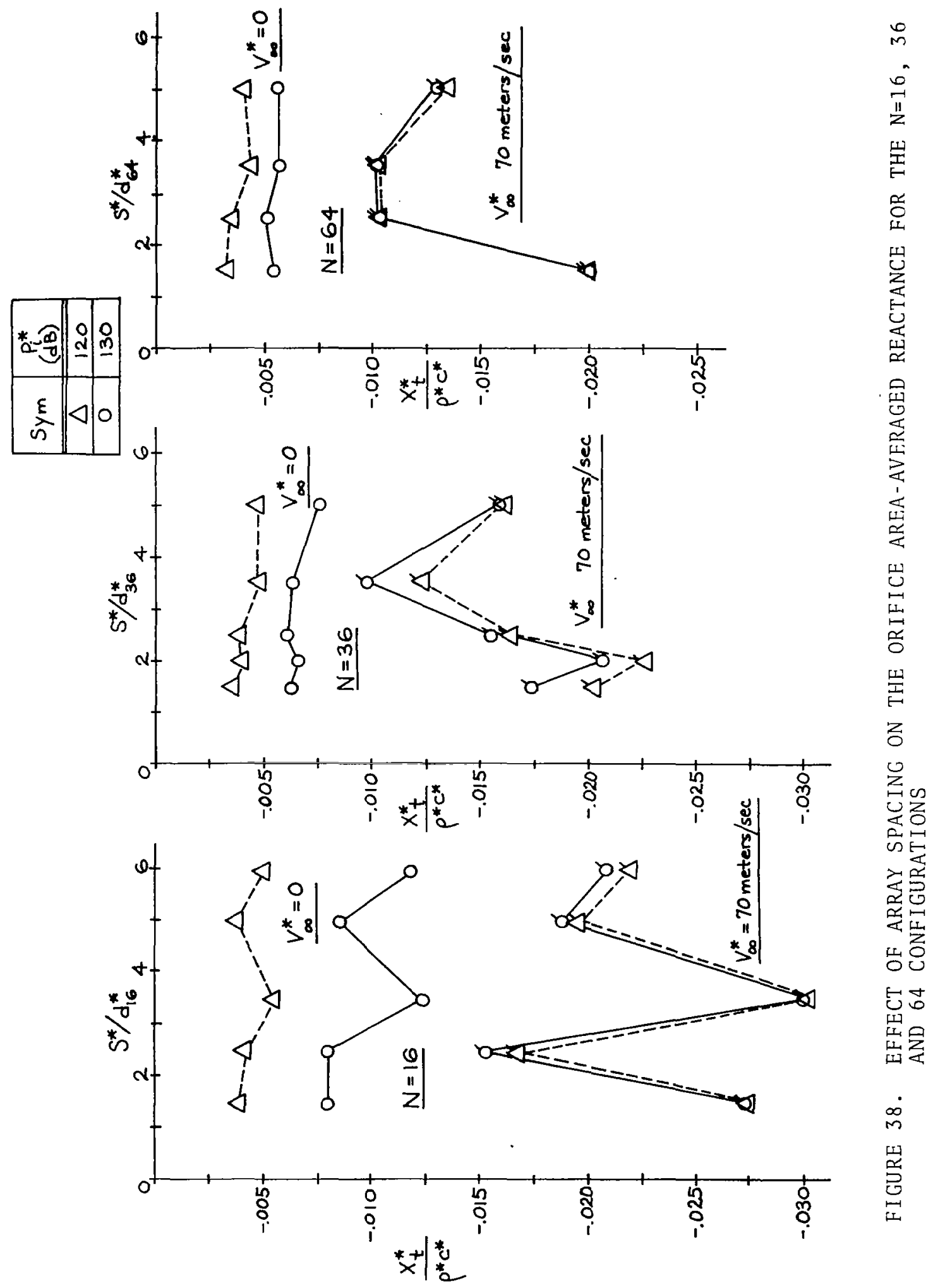




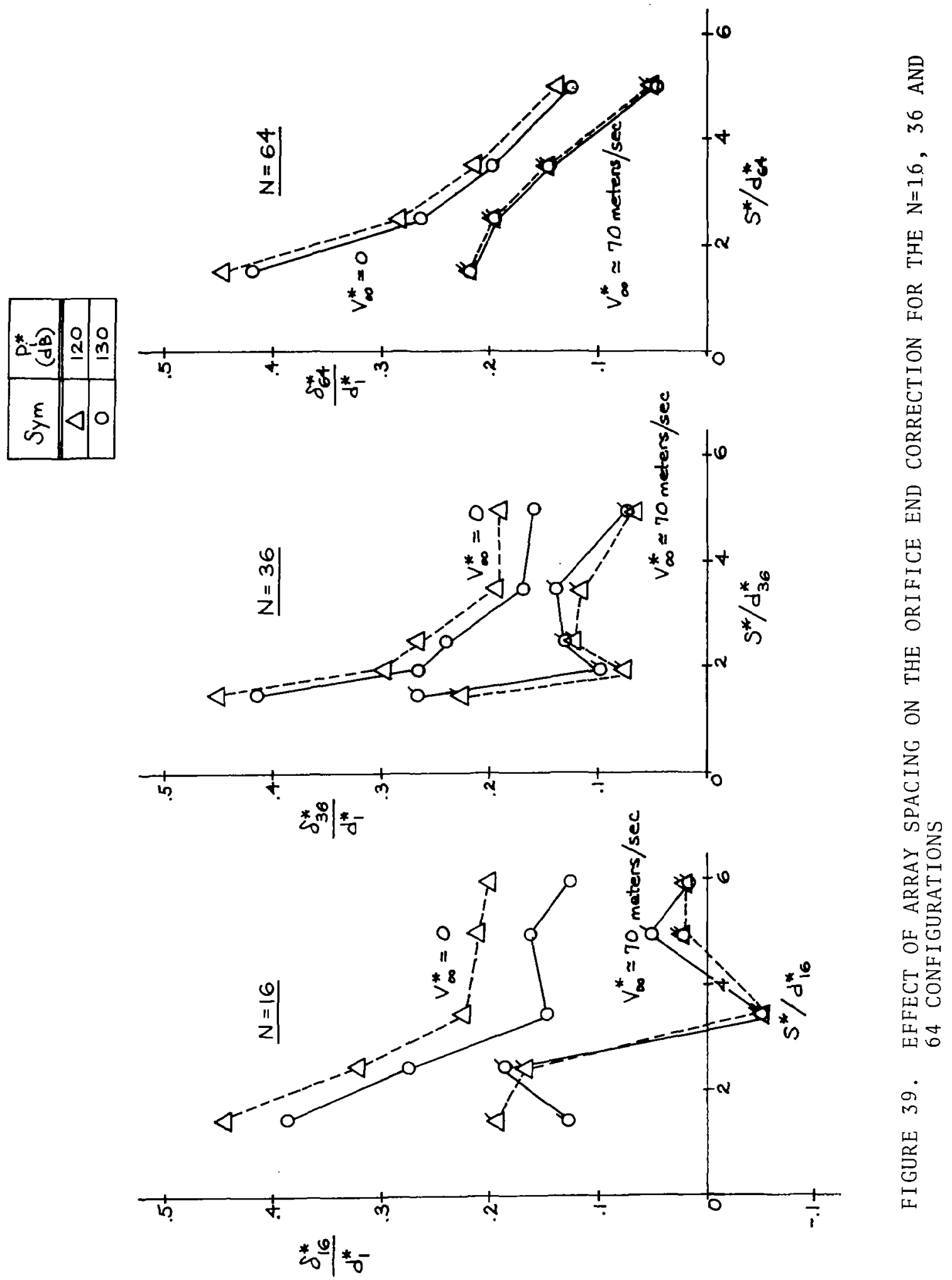




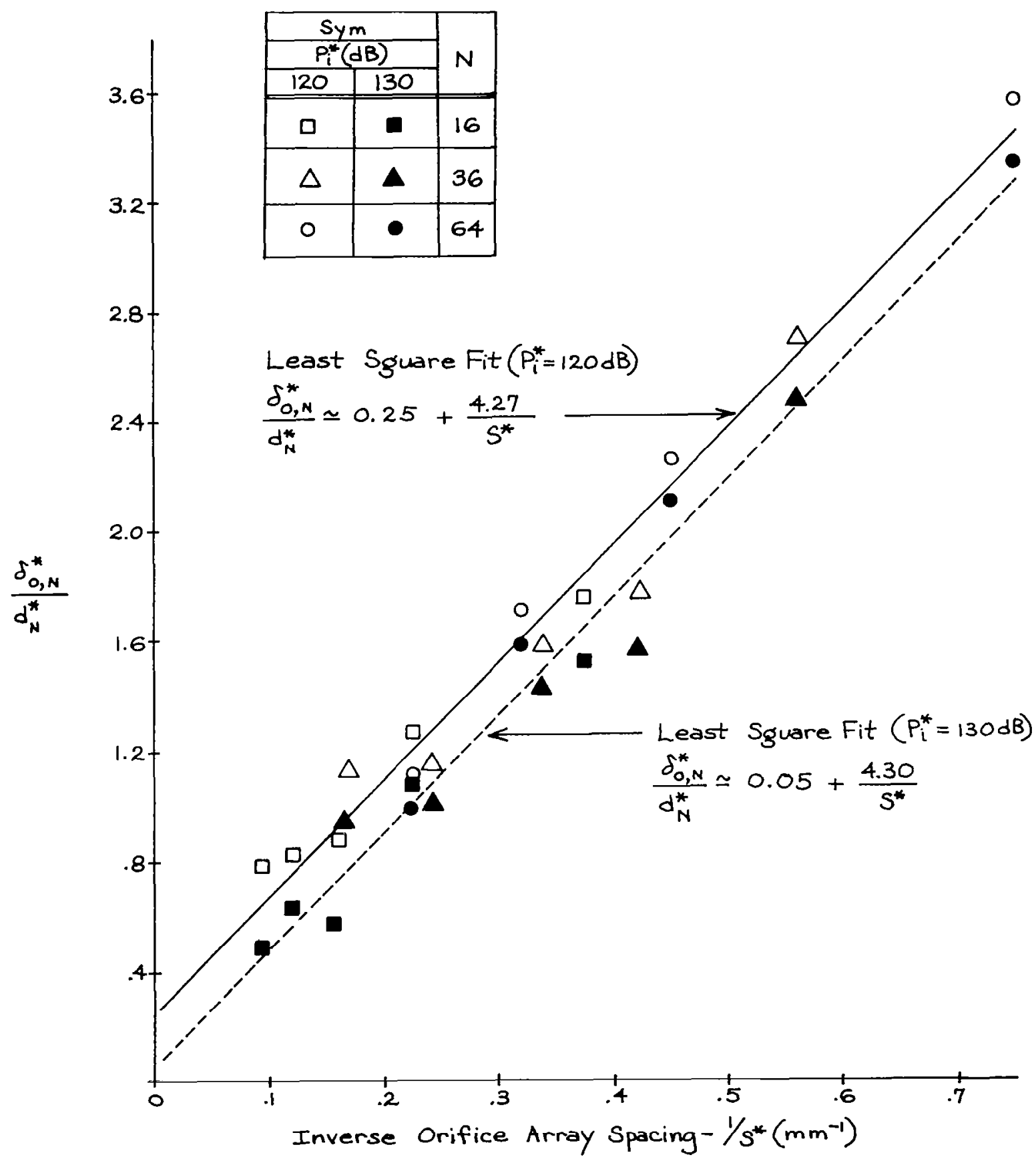

FIGURE 40. EFFECT OF ARRAY SPACING ON ORIFICE END CORRECTION FOR $V_{\infty} *=0$ and $\mathrm{P}_{i}^{*}=120,130 \mathrm{~dB}$ 


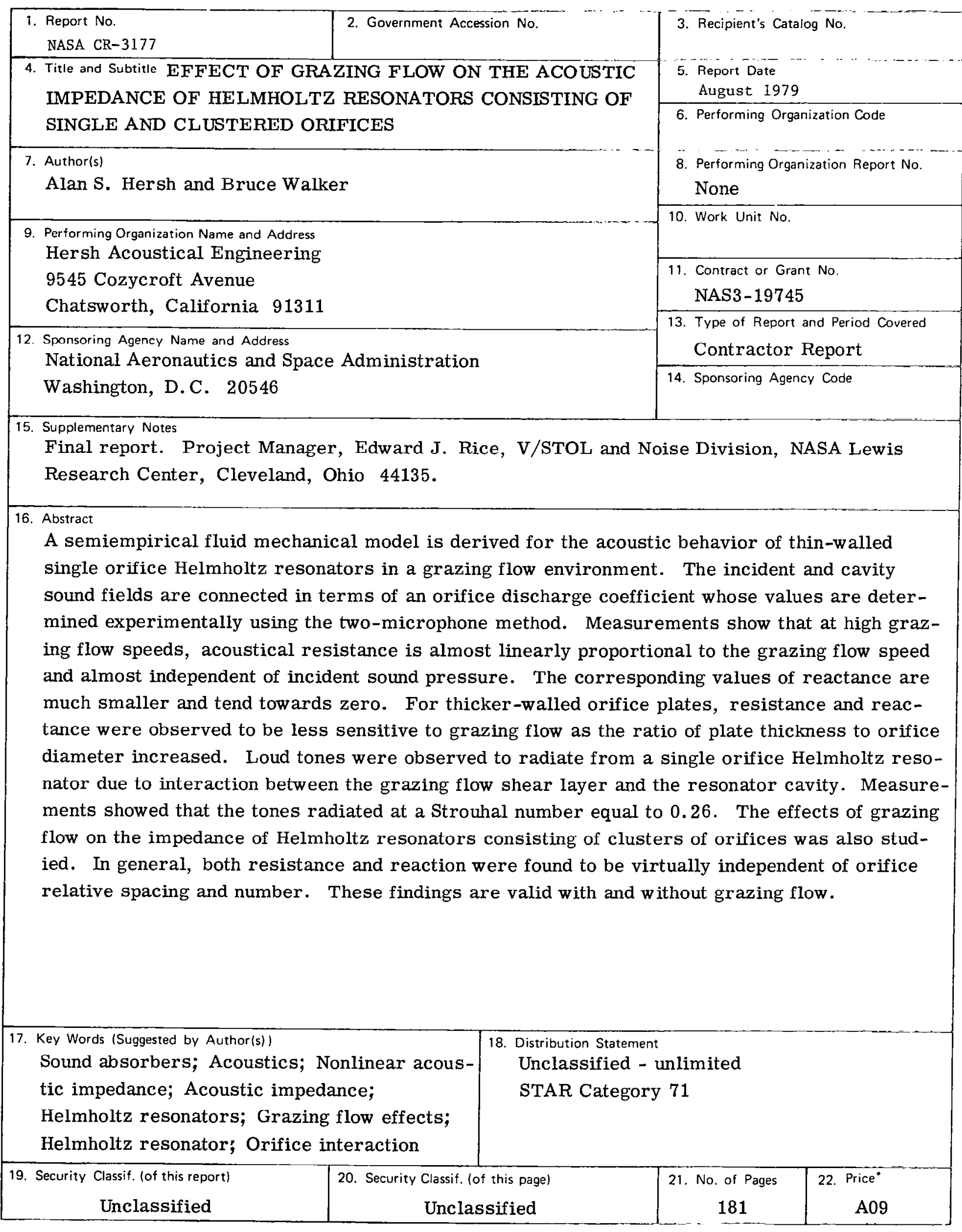

"For sale by the National Techrical Information Service. Springfield. Virgınia 22161 